This dissertation has been $62-2138$ microfilmed exactly as received

H ACKETT, John Thomas, 1932CONCENTRATION IN BANKING IN OHIO DURING THE POSTWAR PERIOD.

The Ohio State University, Ph.D., 1961

Economics, finance

University Microfilms, Inc., Ann Ārbor, Michigan 


\title{
CONCENTRATION IN BANKING IN OHIO \\ DURING THE POSTWAR PERIOD
}

\begin{abstract}
Dissertation
Presented in Partial Fulfillment of the Requirements for the Degree Doctor of Phi losophy in the Graduate School of The Ohio State University
\end{abstract}

By

JOHN THOMAS HACKETT, B.S., M.B.A.

The Ohlo State University

1961

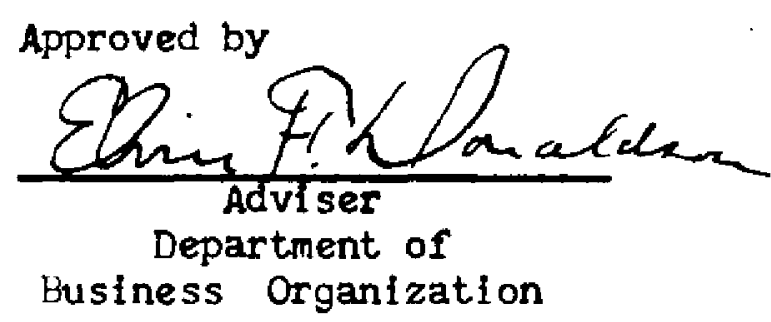




\section{ACKNOWLEDGMENTS}

The author is indebted to his adviser, Dr. E. F. Donaldson, for his guidance, criticism, and encouragement, and to the other members of the reading comittee, Dr. Frances Quantius and Professor Leo D. Stone, for their helpful suggestions.

A spectal word of thanks is given to the officers of the Federal Deposit Insurance Corporation, Federal Reserve Bank of Cleveland, Chio Division of Banks, and the Ohio Bankers Association for the advice and statistical material they provided.

The writer is grateful to the offlcers of the banks who cooperated in the case studies, and to the many Ohio bankers who generousiy contributed time and information to the study. 
COWTENTS

PAGE

List of Tables. . . . . . . . . . . . . . . . . . . . . vi CHAPTER

I. INTRODUCTIUN. . . . . . . . . . . . . . . . . 1

Purpose of the Study . . . . . . . . . . . 5

Need for the Study ............. 6

Scope of the Study . . . . . . . . . . . 9

Methodology. . . . . . . . . . . . . . 12

Organization of the Study. . . . . . . . . . 13

II. THE POSTWAR BANKTIG STRUCTURE IN OHIO . . . . . . . 16

Number of Banks and Banking Offices. . . . . . 16

New Bank Formations. . . . . . . . . . . 26

Savings Banks and Unlncorporated Banks . . . . 29

Geographic Dispersion of Banks. . . . . . . 32

Federal Deposit Insurance Corporation and

Federal Reserve Membership Anong Banks in Ohio 34

Financial Structure of Banks in Ohio...... 38

Income and Operating Expense of Banks in Ohio. . 60

Sunnary . . . . . . . . . . . . . 70 
III. BANKING CONCENTRATION AND CONPETITION IN OHIO. . 75 Concentration Exercised by the Large

Metropolftan Banks in Ohfo During the

Postwar Period............. 75

Geographlc Concentration........... 80

Comparison of Bank Concentration in Ohio and

the United States. ............ 85

The Economies of Large Scale Banking in Ohio. . 86

Competition In Banking in Ohio.......... 91

Sumary ................... 113

IV. BRANCH, GROUP, AND CHAIN BANKIMG IN OHIO BANKING

DURING THE POSTWAR PERIOD ........... 117

The Growth of Branch Banking in Ohlo. . . . . 117

Pattern of Branch Banking in Ohlo. . . . . . 122

Priwary Causes of Increased Branch Banking. - 127

Bank Supervision and Branch Banking In Ohlo . . 135

Group and Chain Banking in Oh: o........ 142

Advantages and Disadvantages of Group Banking

with Particular Reference to the Bancohlo

Corporation. . . . . . . . . . . 155

Swuary . . . . . . . . . . . . . . . 162 
V. POSTWAR BANK CONSOLIDATIONS AND MERGERS IN OHIO. - 166 Methods of Acquisition. . . . . . . . . 166

Bank Consolidations and Mergers In Ohio . . . 170 Factors Contributing to Bank Mergers and Consolidatlons During the Postwar Perled . . 176 Regulation of Bank Consolidations and Mergers - 188 Sumary . . . . . . . . . . . . . . . 201

VI. SELECTED CASE STUDIES OF RECENT BANK

CONSOLIDATIONS AND MERGERS IN OHIO. . . . . . 206 Methods Exployed In Selecting the Case Studies. 207

Case Study 1. . . . . . . . . . . . . . 211

Case Study 2 . . . . . . . . . . . . . . 224

Case Study \#3... . . . . . . . . . . . 239

Sumary. . . . . . . . . . . . . . . . 254

VII. SUMMARY AND CONCLUSIONS. . . . . . . . . . . 257

Swmary .................... 258

Conclusions.................... 270

APPENDIX. . . . . . . . . . . . . . . . . . . . 275

BIBLIOGRAPHY. . . . . . . . . . . . . . . . . . . . $30 \mathrm{C}_{4}$

AJTOBIGGRAPHY . . . . . . . . . . . . . . . . . . . . . . . . . . . . . . . 


\section{LIST OF TABLES}

TABLE

PAGE

1. Total Humber of Banks, Branch Bauks and Banking Offices in Ohio, 1945-1959........... 18

2. Average Number of Persons Per Bank and Banking Office in Chio and the Unfted States, 19451959. . . . . . . . . . . . . . . . .

3. Total Wuber of State Banks, Branch Banks and Banking Offices in Ohio, 1945-1959.......

4. Total Humber of National Banks, Branch Banks, and Banking Offices in Ohio, 1945-1959. ......

5. Now National and State Banks Authorized in Ohio, 1945-1959. . . . . . . . . . . . .

6. Muber of Banks in Ohio with Membership in the Federal Deposit Insurance Corporation, 19451959. . . . . . . . . . . . . 35

7. Number of Banks in Ohio with Membershlp in the Federal Reserve System, 1945-1959... . . . 37

8. Total and Average Assets of A11 Banks, National Banks, and State Banks in Ohio, 1945-1959...

9. Composition of Total Assets of All Benks in Onio, 1945-1959. . . . . . . . . . . . .

10. Total Deposits of A11 Banks, National Banks, and State Banks in Ohio, 2945-1959......... 50

11. Total Denand Deposits of A11 Banks, Mational Banks, and State Banks in Ohio, 1945-1959 ... 51

12. Total Tine Deposits of All Banks, National Banks, and State Banks In Ohio, 1945-1959....... 52

13. Total Capital of All Banks in Onlo, 1945-1959. . 55 
14. Couposition of Operating Incone of A11 Banks in Ohio, 1945-1959............. 61

15. Rate of Income on Total Loans and Investments of A11 Banks in Ohio, 1945-1959..........64

16. Conpesition of Operating Expense of A11 Banks in Ohi o, 1945-1959................ 66

17. Total Net Income of A11 Banks in Ohio, 1945-1959. 69

18. Percentage of Total Bank Assets, Deposits, and Capital in Ohlo Controlled by the 20 Largest Banks In Onio in 1945 and 1959.........

19. Deposits of Individuals, Partnerships, and Corporations in the Metropolitan Counties of Ohio, December $31,1947 . \ldots$

20. Deposits of Individuals, Partnerships, and Corporations in the Metropolitan Countles of Ohlo, Decenber 31, 1959 ............

21. Operating Ratios for A11 Federal Reserve Menber Banks in Ohio Grouped by Asset Size, 1959...

22. Nuber and Selected Balance Sheet Data of $A 11$ Savings and Loan Associations in Ohio, 1945 1959. . . . . . . . . . . . . . . .

23. Number and Total Assets of Al1 Credit Unions in Ohi o, 1945-1959............... 107

24. Annual Purchase of United Savings Bonds in Ohio, 1945-1959............... 108

25. Number of offices and Total Assets of A11 Consuner Loan Compantes in Ohlo, 1946-1959. . . 110

26. Premius Recelved in Ohlo by Life Insurance Companies Authorized to Operate in Ohlo, 1945-1959. . . . . . . . . . . . . . .

27. Number of Branch Offices Established by All Beniks, Mational Banks, and State Banks in Ohi o, 1945-1959. 
28. A11 Banks, National Banks, and State Banks in Oni With and Without Branch Offlces, 1945-1959. . .

29. Number of Branch Banks Operated by the 20 Largest Banks in Ohio in 1945............. 124

30. Nuber of Branch Banks Operated by the 20 Largest Banks in Ohio in 1959 ............. 125

31. Number and Percentage of All Branch Banks in Ohio Located in the Ohio Metropolitan Counties in 1945 and 1959. . . . . . . . . . . . .

32. Nuber of Banks in Ohto Absorbed through Conselldation or Merger; 1945-1959. . . . . .

33. All Banks In Ohlo Absorbed through Consolidation or Merger, Classified According to Amount of Assets, 1945-1959. . . . . . . . . . . .

34. All Acquiring Banks in Ohio, Classified According to Anount of Assets, 1945-1959........ 175

35. Bank A Statement of Condition, December 31, 1957 . 215

36. Bank B Statement of Condition, December 31, 1957 . 218

37. Bank B Statement of Condition, October 5, 1955. - 229

38. Bank C Statement of Condition, October 5, 1955 . . 231

39. Bank A Statement of Cond1tion, March 4, 1958. - 244

40. Bank B Statement of Condition, March 4, 1958 . . 246

41. Number of Unincorporated Banks In Operation in Onio, 1945-1959............. 276

42. Location of National and State Banks In Onlo by County, 1945-1959............... 277

43. Total Loans and Di scounts of A11 Banks, Nat Ional Banks, and State Banks in Ohio, 1945-1959. 
44. Composition of Total Loans and Discounts of A11 Benks in Ohio, 1945-1959........... 281

45. Composition of Total Capital of A11 Banks in Onfo, 1945-1959................

L6. Total Dividends on Common Stock of A11 Banks in Ohio......................

47. Total Assets, Deposits, and Capital of the 20 Largest Banks in Onio, December 31, 1945. . . 266

48. Total Assets, Deposits, and Cepital of the 20 Largest Banks in Ohio, December 31, 1959....

49. Assets and Liabilities of All Insured Comercial Benks in the United States, Grouped by Deposit

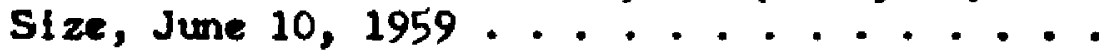

50. Percentage Composition of Assets and Llabilities of All Insured Comnercial Banks in the United States, Grouped by Deposit Size, June 10, 1959. . . . . . . . . . . . . . .

51. Assets and Liabilities of A11 Insured Commercial Banks in Ohio, Grouped by Deposit Size,

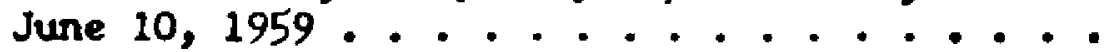

52. Percentage Composition of Assets and Liabilities of All Insured Comerclal Banks In Ohio, Grouped by Deposit Size, June 10, 1959. . ...

53. Distribution of Branch Banks in Ohlo in Relation to the Location of the Parent Bank, 1945-1959..................

54. Total Resources and Branch Offices of All Banks Afflilated with the Bancohio Corporation, Decenber $31,1945 . \ldots$

55. Tota1 Resources and Branch Offices of All Banks Afflilated with the Bancohto Corporation, Dicember 31, 1959 .............. 
CHAPTER I

INTRODUCTION

Commercial banks play an important part in the economic stability and growth of the United States. In addition to serving as depositories for a large portion of the nation's wealth, they provide much of the short, intermediate, and long-term credit to business, agriculture, goverment, and to individuals. Equally important, the comercial banking system serves as the medium through which the nation's money supply is controlled.

Because of the nature of the services provided by comercial banking, it is in the public interest that the banking structure remain responsive to the needs of the economy.

Banking institutions perform a middleman's function. Their primary purpose is to serve business and commerce. To do this satisfactorily, the banking system must change to meet the needs of an ever-changing business and commercial organization. 1

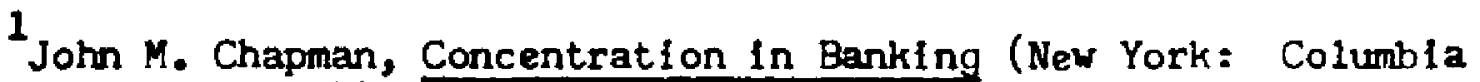
University Press, 1934), p. 4 .
}

The banking system of the United States, however, has not met the need for structural change as swiftly as have other sectors of the economy. In the United States the chartering and regulation of banks is divided between the state and federal governments, and under this 
system uniformity of legislation and regulation is not possible. The reluctance toward change is also caused by the desire to protect the unit banking system. Traditlonally, the American banking system has been composed of a large number of small independent banks serving the needs of local areas.

The oldest and most deeply established tradition ia, American banking is local autonony. While other advanced countries have adopted nation-wide branch banking, the United States has elung to local or reglonal autonomy in banking in the face of the strong tendency towards the evolution of large geographically integrated enterprises throughout industry and trade. ${ }^{2}$

${ }^{2}$ Marcus Nadler and Jules I. Bogen, The Bank Holding Company (New York: New York Unlversity Graduate School of Business Administram tion, 1958), p. 8 .

In the Unlted States local banking institutlons have been preferred to an extensive system of branch banks, as found in Canada or Great Britain, in order to make the development of the community or area the primary concern of the local bank. Proponents of unit banking contend that a board of directors composed of local residents understands better the needs of the local area and can be relled upon to fulfill those needs.

As the businesses which commercial banks serve have grown larger, however, there has been a need for a wider range of services, and the small unlt bank has been unable to meet many of these demands. The shift of population away from rural areas tow ard large metropolftan centers has also resulted in a decline in the business of the rural banks. Many 
of the industries located in rural areas have merged with larger organizations with headquarters in metropolitan centers. This too has resulted In a loss of business for many small unit banks.

Local autonony in banking fails to serve its purpose when the local bank does not earn a profit adequate to provide the banking services which the community requires. The inabllity of many small banks to provide continued service in periods of economic adversity is reflected in the rapid decline in the number of commerclal banks between 1920 and 1940. In 1921 the number of commercial banks in the United States reached the all-time high of 30,546 . In the nineteen years which followed 16,012 commercial banks efther falled and passed out of existence, were absorbed through merger or consolidation, or underwent voluntary 11 quidation. 3

3Federal Reserve Board of Governors, All-Bank Statistics United States, 1896-1955 (Washington, D.C.: Federa1 Reserve System, 1959), p. 37 .

The agriculture depression of the 1920's and the industrial depression of the $1930^{\prime}$ s were the primary causes of the inabillty of many of the banks to continue operation; however, it was among the unit banks operating in rural areas that the heavfest losses occurred. The changes in banking structure during this period led to increased concentration in banking. 
Concentration in banking is generally recognized as a trend in which a larger proportion of the total banking resources comes under the control of a smaller number of banks.

The tendency toward concentration in banking may be defined as the transaction of a decreasing proportion of the nation's banking business by separate and independent managed banks. 4

4u. S., Congress, Senate, Comittee on Small Business, Concentration of Banking in the United States, 82nd Cong., and Sess., Staff Report of the Federal Reserve Board of Governors, 1952, p. 2.

The proble of concentration in banking in the United States continued after 1940. The small, Independent local bank is still the predominant type, but a few large metropolitan banks control the najority of bank resources.

The American banking system has long been characterized by a large number of relatively small banks. In 1959 more than half the banks in the country had less than $\$ 10$ million in deposits and more than 30 per cent had less than $\$ 2$ milit on deposits. However, in that year 67 banks controlled more than 40 per cent of the assets. 5

5 U. S., Congress, House, Comnlttee on Sall Business, Banking Concentration and Sma11 Business, 86th Cong., 2nd Sess., 1960, H. Res. 51 .

The continued decline in the number of unlt banks during the post-World War II period has resulted, however, from a different set of circumstances than those which accompanied the decline of the preceding twenty years. Instead of economic crises, the latter period has been 
characteri fed by larger personal income, a growing urban population, rapid industrial growth, and larger commercial and industrial organtzations. These factors have exercised a strong influence on the present structure of banking.

Whatever form our banking structure has taken, it was inevitable that, as our economy grew and developed larger and larger business units for production and distribution, larger units of banking and consequently some concentram tion would result. As urban population grew relative to rural population and especially metropolitan areas increased in nuber and size, banking needs becane more concentrated. The location of head or regional offices of large corporations in financial centers contributed especially to this trend since it gave rise to the need for large banking unlts capable of handling large transactions.6

6. S., Congress, Senate, Committee on Small Business, Concentration of Banking in the United States, 1952, p. 1.

\section{Purpose of the Study}

The purpose of this dissertation is to provide an analysis of the extent of concentration in the banking structure of ohio from 1945 to 1959. In addition, the study w1ll analyze the factors which tend to induce concentration, and the primary means whereby bank concentram tion is attained.

The problem of concentration in banking should not be accepted as evil per se. This study is an attempt to arrive at an objective evaluation of the desirability of bank concentration, to pave the way 
for more adequate regulation of banking, and to provide a better understanding of the causes and methods of bank concentration.

\section{Need for the Study}

The decline in the number of unit banks during the 1930's encouraged economists to take an interest in the causes and methods of bank concentration. ${ }^{7}$ After 1945 , however, more attention was directed toward

${ }^{7}$ Chapman, Concentration in Banking, p. 6.

the problems of monetary policy, and the preoccupation with monetary policy resulted in the temporary decline of banking structure as an area of research.

In the years following World War II monetary pollcy regained much of the attention it lost in the postm Keynesian disalssal of monetary pollcy as an important stablilzation tool. Money and banking speclallsts both before and after the accord the accord of 1951 between the Federal Reserve authorities and the Treasury Department concerning the Federal Reserve pollcy of supporting the price of Treasury bonds through open narket operations7 spent considerable time and effort debating the effects and effectiveness of monetary policy.

8aul M. Horvitz, Concentration and Competiti on in New England Banking (Boston: Federal Reserve Bank of Boston, 1958), p. 5. 
In recent years, however, there has been a renewed interest on the part of various nembers of Congress in the structure of commercial banking. 9 Much of this interest is a result of the increased number

${ }^{9}$ The Senate and House Conenittees on Banking and Currency and the House Comittee on the Judiclary have both held numerous hearings on various aspects of bank concentration since 1950. The Select Committee on San11 Business of the House of Representatives has also sponsored a number of reports concerned with bank concentratlon.

of bank mergers and consolidatl ons that have taken place since 1950. The research provided through Congressional action, however, has been national in scope.

A study of banking competition on a national scale provides 11ttle more than a brief analysis of the varlous factors which have brought about the changes in bank structure. After an attenpt to analyze the bank merger movement on a national basis. Professor John Ryan of Fordham University concluded his report with the following paragraph:

If any conclusion emerges fron this study it is that the number and size of bank mergers in the United States are very largely a local problem. We can learn little of practical value if we confine our attention solely to a nation-wide viewpolnt. - . Fur ther knowledge on this subject can cone only from study and analysis on a local basis. 10

10 John Ryah, "Inability of Bank Mergex Law to Deal with Local Mergers," The Comercial and Financlal Chronicle, October 18, 1956, p. 18 . 
The state of Ohio is a leader among the 50 states in commercial banking. As of December 31, 1959, Ohio ranked eighth among the 48 states in the number of banks and fourth in total banking offices. The total assets of banks in Ohio were seventh in the nation, and the total deposits placed sixth. The total loans and discounts of banks in ohio also ranked sixth in national standing. ${ }^{11}$ In addition, three of the

${ }^{11_{U}}$. S. Treasury Department, Annual Report of the Comptroller of the Currency (Washingtoi, D.C.: United States Government Printing Office, 1960), p. 1112.

nation's fifty largest commercial banks were located in ohio. ${ }^{12}$

\footnotetext{
12 "The Fortune Directory, Part II," Fortune Magazine, August, 1959 , p. 138 .
}

The structure of banking in Ohio also changed rapidly from 1945 to 1959. In 1945,175 branch banks were in operation in Ohio, and by 1959 the number had grown to $601 .^{13}$ In 1959 , Ohio placed fourth among

${ }^{13}$ Annual Report of the Federal Deposit Insurance Corporation, 1945 and 1959.

the 50 states in the number of branch banks in operation. 14

${ }^{14}$ Ibid.

From 1945 to 1959, 106 bank mergers and consolidations took place between banks in Ohio. Only California, New York, and 
Pennsylvania reported more bank comblnations than Ohio during this 14-year period. 15

15. S., Congress, Senate, Comittee on Banking and Currency, Hearlngs on S. 1062, Regulation of Bank Mergers, 86th Cong., 1st Sess , 1959, pp. 139-179.

U. S., Congress, House, Conmlttee on Banking and Currency, Hearings, on S. 1062, Regulation of Benk Mergers, 86th Cong., 2nd Sess., $1960, \mathrm{pp} \cdot 20-23$.

Although Ohio maintains a prominent position in banking, a comprehensive study of banking In Ohlo was last undertaken in 1940.16

16 J. M. Whitsett, Banking Operations in Ohio, 1920-1940 (Colubus, Ohio: Onio State University Bureau of Business Research, 1941).

That study provided an elaborate analysis of the structure of banking In the state; however, only brief mention was given to the problem of concentration of bank resources and facilities.

As a result of Ohio's importance in the nation's comercial banking structure, and the current interest in concentration in bankirg, an investigation of bank concentration in Ohio w 111 provide infornation valuable to bank management, regulatory agencies, and students of finance and banking.

\section{Scope of the Study}

Concentration in banking, as previously defined, refers to an increasing proportion of the total banking business being performed by a sualler number of banks. The destre for a larger operating base in 
banking, as In other lines of business, is without doubt one phase of the concentration movement. Such factors, however, as changes in the number of unit banks, the extent of branch chain, and group banking, the growth of competing nonbank financial institutions, and the geographic distribution of banks and banking offices are a necessary part of a study of concentration.

A study of the concentration movement involves a discussion of the changing unit bank, the growth and extent of bank mergers and consolidations, the development and status of branch banking, the history and problems involved in chain banking, and a copsideration of the more recent appearance of group banking. 17

${ }^{17}$ Chapman, Concentration in Banking, p. 5.

Each of these factors must be examined to determine the extent of its contribution as elther a cause or a deterrent of concentration. Analysis of nonbank financial institutions has been recognized as an important phase of the study of bank competiti on and concentration. 18

18. S., Congress, Senate, Concentration of Banking in the U. S., 1952, p. 2 .

For the purposes of this study, however, attention to nonbank financial Institutions will be 11 mited to those which are in direct competition with banks in ohio for consumer savings and lending, and for which statistics on operation in Ohio are available.

The term "postwar period" creates confusion when one falls to designate which war preceded the period in question. In this study 
the postwar period refers to the period beginning December 31,1945 and ending December 31, 1959.

In order to assure a full analysis of bank concentration in Ohio, the definition of a bank as set forth in the Ohio banking laws has been adopted.

"Bank" includes, uniess the context otherwise requires, any person, firm, association, or corporation soliciting receiving, or accepting money or its equivalent on deposit as a business, whether such deposit is made subject to check or is evidenced by a certificate of deposit, a passbook, a note, a receipt, or any other writing, and also includes comercial banks, savings banks, trust companies, special plan banks, and unincorporated banks. Such chapters do not apply to money left with an agent pending investment, in real estate or securities, for or on account of his principal; to building and loan associations or title guarantee and trust companies incorporated under the laws of this state; or to money or its equivalent received for transmittal by an incorporated rallroad, steamship, express, or telegraph company. 19

\section{${ }^{19}$ Banking Laws of Ohio Annotated (Ohio Department of Commerce, 1958), c. 1101, sec. 01 .}

As a result of the broad interpretation of a bank provided by Ohio law, the mutual savings banks located in Ohio wlil be included as a banking institution. 20 An additional reason for including mutual

${ }^{20}$ Ohio law forbids the use of the term. "Dank" in the title of a mutual savings bank. Chapter 1109 , section .02 of the Ohlo banking laws states ". . a mutual savings bank wi thout capi tal stock, to be known as a society for savings or a savings society. . " However, a savings society is subject to the banking laws of ohio, and is regulated by the Ohio Superintendent of Banks. 
savings banks is the 1955 amendment to Ohio law which allows these institutions to organize or acquire the stock of commerclal banks. ${ }^{21}$ 21 Ohio, Banking Laws, Annotated, c. 1109, sec. 051.

This, in effect, permits a mutual savings bank to indirectly accept demand deposits.

\section{Methodology}

An exaination of concentration in banking requires the use of varied methods of analysis and investigation. The primary approach is based on an examination and evaluation of the aggregate trend toward concentration. The purpose in selecting this method is to allow a closer examination of the effects of concentration on banking in Ohio.

A substantial part of the Investigation is devoted to an analysis of the causes of growth in branch banking and bank nergers and consolidations. Material of this nature does not lend itself to quantitative measure. Much of this analysis is a survey of the factors which induce these changes in the banking structure. The observations and impressions of bankers, supervi sory of ficials, and the officers of banking assoclations have been gathered to afford a better insight into the present cause of these changes.

Extensive use has been made of the statistical material provided in the reports and records of various governmental agencies and trade associations such as the Comptroller of the Currency, the 
Federal Deposit Insurance Corporation, Federal Reserve System, the Banking Division and Securlties Division of the Onlo Department of Commerce, Ohio Bankers Association, the Ohio Savings and Loan League, and the Ohio Credit Union League.

Private sources of information have been examined also, namely, banking journals, law reviews, financial newspapers, surveys and monographs published by universities and private organizations, and banking directories. These sources furnish an explanation of many general and technical problems of bank structure and provide a limited amount of statistical information.

The case study method is employed in an investigation of a snall number of carefully selected bank mergers and consolidations in ohlo. This method of research provides a close examination of the intrabank and interbank reasons for comblnation, and a better understanding of the financial and legal problems involved. In addition, the postmerger effect upon the banking community is assessed. The studies were conducted by the use of extended Interviews with offlcers of the subject banks, examination of pertinent records which bank managements nade avallable, and interviews with businessmen and residents of the affected comunities.

\section{Organi zation of the Study}

In exanining the problem of bank concentration in onlo a definite organizational plan is followed. The introductory chapter 
sets forth the purpose, need, and scope of the study. In addition, Chapter I outlines the methods employed in the Investigation.

Chapter II is designed to provide an analysis of the aggregate banking structure of ohlo during the postwar period, and to analyze the changes which have taken place. This chapter provides the setting for the balance of the study. Chapter II gives particular attention to the number, location, and affiliations of banks in ohio, and the financial structure of these institutions.

The purpose of Chapter III is to measure and analyze the trends In the concentration of resources and the geographical concentration among benks in Ohio during the postwar period, and to provide a ceaparison of bank concentration in Ohio with that of the total United States. In this chapter an exanination is made al so of competition between banks and of the competition resulting from the postwar growth of consumer savings and lending institutions.

Chapters IV, V, and VI serve as core chapters in the examination of the primary causes of bank concentration. Chapter IV deals with branch, group and chain banking in Ohlo during the postwar period. A statistical sumary of the growth and pattern of branch banking is provided in conjunction with a qualitative analysis of the causes of the branch movenent. The examination of branch banking is followed with a survey of group banking in Ohio, and the economies and diseconomles of the group banking system. 
The subject of Chapters V and VI is bank mergers and consolidations. Chapter $V$ examines the pattern and the causes of postwar bank combinations in Ohio. It also provides an analys is of state and federal regulation of banking combinations. Chapter VI presents the findings of the case studies of Ohio bank mergers and consolidations. The final chapter, Chapter VII, surmarizes the principal findings of the study, and offers tentative solutions to the problems involved in bank concentration in Ohio. 
CHAPTER II

THE POSTWAR BANKING STRUCTURE IN OHIO

The purpose of Chapter II is to examine the postwar banking structure of Ohio and to analyze the changes which have taken place. Particular attention is given to the number, location, afflilations, and financial structure of the banks and banking offices in onio.

\section{Number of Banks and Banking Offices}

Tables 1, 2, 3, and 4 present the number of banks and banking offices in operation in ohio during the postwar period, and the number of banks and banking offices per capita. The data relating to the number of banks and banking offices is further divided on the basis of total banks, national banks, and state banks operating in Ohio.

\section{A. Total Banks and Banking Offices}

From 1945 to 1959 the total number of banks in Ohio declined from 680 to 590 which is a 13.8 per cent reduction. This decline, however, was not uniform throughout the postwar period. From 1945 to 1950 the total number of banks in Ohio was reduced by 18, and in the following five years, 1950 to 1955, the total declined by 36 banks. In the remaining four years, 1955 to 1959, this number was further reduced by 36 banks. In 1959, the number of banks in Ohio declined by 18 , which was the largest decline in any single year of the 14 -year period. 
The total number of banking offices in Ohio includes all banks and branch bank offices. Banking offices have increased by 39.0 per cent in Ohio during the postwar period as show in Table 1. The total number of banking offices expanded from 855 in 1945 to 1,191 in 1959. The expansion in the number of banking offices has also falled to follow a uniform pattern. From 1945 to 1950, 33 additional banking offices were established in Ohio, and in the following five years 118 additional banking offices were provided. The remaining four years showed the most rapid increase in the postwar period when 185 banking offices were established in Ohio.

The increase in banking offices during a perlod of decline in the number of banks resulted from the expansion of branch banking operations in Ohio. From 1945 to 1959 the number of branch banks in Ohio Increased from 175 to 601 . The initial five years of the postwar period accounted for only 51 additional branch banks; however, in the period 1950 to 1955154 branch banks were authorized. During the final period, 1955-1959, 221 addftional branch operations were establi shed in chio.

The growing importance of branch banks as a proportion of total banking offices in Ohio is also reflected in the fact that in 1945 20.6 per cent of the total banking offices were branch banks, but by 1959 branch banks accounted for 50.4 per cent of the total banking offices in Ohio. 
TABLE 1

TOTAL NUMBER OF BANKS, BRANCH BANKS AND BANKING OFFICES IN OHIO

$1945-1959$

\begin{tabular}{lcccc}
\hline Year & $\begin{array}{c}\text { Number } \\
\text { of } \\
\text { Banks }\end{array}$ & $\begin{array}{c}\text { Number } \\
\text { of } \\
\text { Branch } \\
\text { Banks }\end{array}$ & $\begin{array}{c}\text { Total } \\
\text { Banking } \\
\text { offices }\end{array}$ & $\begin{array}{c}\text { Total Branches } \\
\text { as a Per cent } \\
\text { of Total } \\
\text { Bank1 ng offices }\end{array}$ \\
\hline 1945 & 680 & 175 & 855 & 20.6 \\
1946 & 677 & 176 & 853 & 20.7 \\
1947 & 671 & 189 & 860 & 22.1 \\
1948 & 669 & 204 & 873 & 23.4 \\
1949 & 664 & 215 & 879 & 24.5 \\
1950 & 662 & 226 & 888 & 25.5 \\
1951 & 659 & 246 & 905 & 27.3 \\
1952 & 654 & 271 & 922 & 29.4 \\
1953 & 647 & 308 & 952 & 32.1 \\
1954 & 637 & 343 & 980 & 34.4 \\
1955 & 626 & 380 & 1,006 & 37.2 \\
1956 & 620 & 446 & 1,066 & 41.3 \\
1957 & 614 & 503 & 1,117 & 44.6 \\
1958 & 608 & 565 & 1,173 & 47.6 \\
1959 & 590 & 601 & 1,191 & 50.4 \\
\hline & 650 & & & \\
\hline
\end{tabular}

Source: Anmual Reports of the Federal Deposit Insurance Corporation, 1945-1959. 


\section{B. The Number of Bants and Banking Offices Per Capita}

One measure of the adequacy of banking facillties is the average number of persons served by each bank and banking office. Table 2 presents these statistics for Ohio and the United States for the period 1945 to 1959.

During the postwar period the average number of persons per bank in Ohio increased by 60.4 per cent. In that $1 h_{+}$-year period the average number of people per bank in Ohlo rose from 10,215 to 16,403 . During the same period the average number of persons per bank in the United States increased from 9,220 to 12,283 providing a 39.0 per cent Increase. In 1959 the average number of persons per bank in Chio exceeded the average for the United States by 27.9 per cent. Only a part of the increase in the number of persons per bank in Ohio, however, can be attributed to the decline in the number of banks during the postwar perfod. In the same 14-year period the population in ohio expanded by 39.4 per cent. ${ }^{1}$ In addition, during the perlod 1950 to

Toivision of Economic Research, Ohio Population Growth and Distribution (Columbus, Ohio: Ohio Department of Industrial and Economic Development, 1960).

1959, Ohlo accounted for 7 per cent of the total population growth in the country, and placed fourth among the states in numerical population growth.?

2

Ibid., p. 1 . 
TABLE 2

AVERAGE NURBER OF PERSONS PER BANK AND BANKING OFFICE

IN OHIO AND THE UNIVED STATES

1945-1959

\begin{tabular}{ccccc} 
Year & $\begin{array}{c}\text { Number of Persons } \\
\text { per Bank in Onio }\end{array}$ & $\begin{array}{c}\text { Number of Persons } \\
\text { per Bank in the } \\
\text { United States }\end{array}$ & $\begin{array}{c}\text { Number of Persons } \\
\text { per Banking Office } \\
\text { in Ohio }\end{array}$ & $\begin{array}{c}\text { Number of Persons } \\
\text { per Banking Office } \\
\text { in the United States }\end{array}$ \\
\hline 1945 & 10,215 & 9,220 & 8,117 & 7,185 \\
1946 & 11,099 & 9,691 & 8,801 & 7,535 \\
1947 & 11,490 & 9,914 & 8,956 & 7,635 \\
1948 & 11,774 & 10,105 & 9,013 & 7,697 \\
1949 & 12,095 & 10,295 & 9,127 & 7,739 \\
1950 & 12,133 & 10,496 & 9,035 & 7,769 \\
1951 & 12,137 & 10,670 & 8,827 & 7,762 \\
1952 & 12,476 & 10,869 & 8,809 & 7,769 \\
1953 & 13,281 & 11,092 & 9,013 & 7,768 \\
1954 & 14,080 & 11,404 & 9,232 & 7,765 \\
1955 & 14,299 & 11,726 & 9,050 & 7,728
\end{tabular}


TABLE 2 (continued)

\begin{tabular}{ccccc} 
Year & $\begin{array}{c}\text { Number of Persons } \\
\text { per Bank in Ohio }\end{array}$ & $\begin{array}{c}\text { Number of Persons } \\
\text { per Bank in the } \\
\text { United States }\end{array}$ & $\begin{array}{c}\text { Number of Persons } \\
\text { per Banking Office } \\
\text { In Ohio }\end{array}$ & $\begin{array}{c}\text { Number of Persons } \\
\text { per Banking Office } \\
\text { in the United States }\end{array}$ \\
\hline 1956 & 14,700 & 11,999 & 8,621 & 7,640 \\
1957 & 15,067 & 12,287 & 8,354 & 7,579 \\
1958 & 15,346 & 12,560 & 8,077 & 7,498 \\
1959 & 16,403 & 12,823 & 8,132 & 7,407 \\
\hline
\end{tabular}

Source: Annual Report of the Federal Deposit Insurance Corporation, 1945-1959 and Statistical Abstract of the United States, 1953 and 1959. 
As a result-of the increase in the number of banking offices in Ohio, the average number of persons served by each banking office remained relatively stable during the postwar pertod. The average in Ohto exceeds the national average but the difference is narrow.

\section{State Banks and.Banking Offices}

An examination of Table 3 reveals that state chartered banks and banking offices have been the most numerous in Ohio. In 1945, 64.5 per cent of all banks in Ohio were operating under charters granted by the Ohio Superintendent of Banks, and this percentage remained relatively stable throughout the postwar period since 62.2 per cent were under state supervision in $195^{\circ}$.

The decline in the number of banks during the postwar period, however, has been principally in state banks. From 1945 to 1959 the number of state banks in operation declined by 71 , and this figure represented 79.7 per cent of the total decline in the number of banks in Ohio during the postwar period.

The total number of banking offices under the control of state chartered banks increased 18.4 per cent in the 14-year period in which 105 additional state banking offices were established in Ohio. Desplte the fact that the number of state banking offices increased, the proportion of total banking offices in ohio under the control of state banks declined from 67.0 per cent in 1945 to 56.9 per cent in 1959. 
The increase in the number of state banking offices in Ohio, in spite of the decline in the number of state banks, resulted from the rapid expansion in the number of state bank branch offices established in the same period. In the 14 years that followed the end of World War II the state banks in Ohio added 176 branch offlce operations throughout the state. These additional branch offlces provided a 131 per cent increase in the number of state bank branches in operation in Ohio. This Increase, however, was well below the 602 per cent increase posted by national banks in ohio during the same period.

The increase in state bank branches is reflected also in the fact that in $1945,23.5$ per cent of all state banking offices in ohio were branch offices, but by $1957,45.9$ per cent of all state banking offices were branch operations.

\section{National Banks and Banking Offices}

Table 4 presents the number of national banks and banking offices operating in Ohio from 1945 to 1959. The number of national banks declined less than state banks in Ohio during the postwar perlod. Fron 1945 to 1959 the total number of national banks in Ohio declined by 18 . As a result of this modest decline, and the relatively large decrease in the number of state banks, the number of national banks in ohio increased from 35.4 per cent of total banks in the state in 1945 to 38.9 per cent in 1959.

Between 1945 and 1959 the total number of national banking offices in ohio increased by 81.5 per cent. The increase in the number of 
TABLE 3

TOTAL NUMBER OF STATE BANKS, BRANCH BANKS, AND BANKING OFFICES IN OHIO

$$
\text { 1945-1959 }
$$

\begin{tabular}{|c|c|c|c|c|}
\hline Year & $\begin{array}{l}\text { Number } \\
\text { of } \\
\text { Barks }\end{array}$ & $\begin{array}{l}\text { Number of } \\
\text { Branch } \\
\text { Banks }\end{array}$ & $\begin{array}{l}\text { Total } \\
\text { Banking } \\
\text { Offices }\end{array}$ & $\begin{array}{c}\text { Total Branches } \\
\text { as a Per cent } \\
\text { of Total } \\
\text { Banking offices }\end{array}$ \\
\hline 1945 & 437 & 134 & 571 & 23.5 \\
\hline 1946 & 435 & 135 & 570 & 23.7 \\
\hline 1947 & 428 & 140 & 568 & 24.6 \\
\hline 1948 & 425 & 149 & 574 & 26.0 \\
\hline 1949 & 420 & 155 & 575 & 27.0 \\
\hline 1950 & 418 & 161 & 579 & 27.8 \\
\hline 1951 & 417 & 165 & 582 & 28.4 \\
\hline 1952 & 413 & 177 & 590 & 30.0 \\
\hline 1953 & 409 & 184 & 593 & 31.0 \\
\hline 1954 & 400 & 192 & 592 & 32.4 \\
\hline 1955 & 393 & 207 & 600 & 34.5 \\
\hline 1956 & 388 & 231 & 619 & 37.3 \\
\hline 1957 & 382 & 255 & 637 & 40.0 \\
\hline 1958 & 378 & 285 & 663 & 43.0 \\
\hline 1959 & 366 & 310 & 676 & 45.9 \\
\hline
\end{tabular}

Source: Annual Report of the Federal Deposit Insurance Corporation, 1945-1959. 
TABLE 4

TOTAL NUMBER OF NATIONAL BANKS, BRANCH BANKS, AND BANKING OFFICES IN OHIO

1945-1959

\begin{tabular}{|c|c|c|c|c|}
\hline Year & $\begin{array}{l}\text { Wumber } \\
\text { of } \\
\text { Banks }\end{array}$ & $\begin{array}{l}\text { Number of } \\
\text { Branch } \\
\text { Banks }\end{array}$ & $\begin{array}{l}\text { Total } \\
\text { Banking } \\
\text { Offices }\end{array}$ & $\begin{array}{l}\text { Total Branches } \\
\text { as a Per cent } \\
\text { of Total } \\
\text { Banking Offlces }\end{array}$ \\
\hline 1945 & 240 & 41 & 281 & 24.6 \\
\hline 1946 & 239 & 41 & 280 & 14.6 \\
\hline 1947 & 240 & 49 & 289 & 17.0 \\
\hline 1948 & 241 & 55 & 296 & 18.6 \\
\hline 1949 & 241 & 60 & 301 & 19.9 \\
\hline 1950 & 241 & 65 & 306 & 21.2 \\
\hline 1951 & 239 & 81 & 320 & 25.3 \\
\hline 1952 & 238 & 94 & 332 & 28.3 \\
\hline 1953 & 235 & 121 & 356 & 33.9 \\
\hline 1954 & 234 & 141 & 375 & 37.6 \\
\hline 1955 & 230 & 162 & 392 & 41.3 \\
\hline 1956 & 229 & 204 & 433 & 47.1 \\
\hline 1957 & 229 & 236 & 465 & 50.8 \\
\hline 1958 & 228 & 266 & 494 & 53.8 \\
\hline 1959 & 222 & 288 & 510 & 56.5 \\
\hline
\end{tabular}

Source: Annual Report of the Federal Deposit Insurance Corporation, 1945-1959. 
national banking offices during this period was 229 , and the proportion of total banking offices in hio under the control of national banks rose from 32.9 per cent in 1945 to 42.3 per cent in 1959.

Natfonal banks in Ohio also added 247 additional branch offices during the postwar period. The addition of these new branch offices resulted in a 602 per cent increase over the number in operation at the beginning of the period. The expansion in branch operations increased the proportion of total branch banks in ohio controlled by national banks from 23.4 per cent in 1945 to 48.1 per cent in 1959.

In $1945,14.5$ per cent of the national bank offices in Ohio were branch offices, but by 1959 the proportion of total national banking offices represented by branch operations had increased to 56.5 per cent.

\section{New Bank Formations}

During the 1h-year period following the end of world war II a combined total of 33 new state and national banks were chartered in Ohio by the Ohio Superintendent of Banks and the Comptroller of the Currency. Table 5 presents the number of state and national bank charters Issued in Ohio during the postwar period, and the year in whlch the charter was granted.

\section{A. New State Banks}

State bank charters were in greater demand than national charters during the postwar perlod in Ohio. The Ohio Superintendent 
TABLE 5

NEW NATIONAL AND STATE BANKS ANTHORIZED IN OHIO 1945-1959

\begin{tabular}{|c|c|c|c|}
\hline Year & $\begin{array}{l}\text { Nati iona 1 } \\
\text { Banks }\end{array}$ & $\begin{array}{l}\text { State } \\
\text { Banks }\end{array}$ & Total \\
\hline 1945 & 1 & 2 & 3 \\
\hline 1946 & 1 & 1 & 2 \\
\hline 1947 & 2 & 1 & 3 \\
\hline 1948 & 1 & 1 & 2 \\
\hline 1949 & & 1 & 1 \\
\hline \multicolumn{4}{|l|}{1950} \\
\hline 1951 & & 3 & 3 \\
\hline 1952 & & 3 & 3 \\
\hline 1953 & 2 & & 2 \\
\hline 1954 & 2 & 1 & 3 \\
\hline 1955 & 1 & 1 & 2 \\
\hline 1956 & & 2 & 2 \\
\hline 1957 & & 2 & 2 \\
\hline 1958 & & 3 & 3 \\
\hline 1959 & 1 & 1 & 2 \\
\hline Total & 11 & 22 & 33 \\
\hline
\end{tabular}

Source: Annual Report of the Comptroller of the Currency, 1946-1960, and Annual Report of the कhio DIvision of Banks, $1945-1960$. 
of Banks authorized 22 bank charters from 1945 to 1959 . There were only two years in the entire postwar perlod in which at least one additional state bank was not formed.

In every case state bank charters were granted for the purpose of forming a new bank rather than converting a national bank into a state chartered institution. ${ }^{3}$ A survey of the communities in which the

${ }^{3}$ Annual Report of the Ohio Division of Banks, $1946-1960$.

new state banks were established revealed that the smaller Ohio communities received the majority of the new state banks. 4 of the 22 new

$$
4 \text { Ibld., } 1946-1960 .
$$

state banks placed in operation since 1945, eight of these were established in communities of less than 1,000 inhabltants, and four of the eight were in communities of less than 500 inhabitants. A total of seven of the new state banks were located in communitles with a population ranging from 1,000 to 5,000. Five of the institutions were formed in communities with 10,000 to 20,000 citizens, and the two remaining banks were located in cities with a population exceeding 20,000 .

\section{B. New National Banks}

The Comptroller of the Currency authorized 11 additional national bank charters in Ohio during the postmar period. 
Five of the 11 national bank charters authorized in Ohio during the postwar perlod were granted for the purpose of converting an existing state bank to a national bank. All national bank charters authorized in onio in 1945, 1946 and 1947 were requested for this purpose, and the fifth conversion took place in 1955.5

\section{${ }^{5}$ Annual Report of the Comptroller of the Currency, 1946-1960.}

A survey of the Ohio communities in which new national banks were established revealed that the new national banks were established in larger communties than new state banks. ${ }^{6}$ A total of flve of the 11

$$
\text { 6Ibid., 1946-1960. }
$$

national bank charters were granted to institutions located in Ohio cities with a population exceeding 100,000 , and two of the new national banks were established in communities of 10,000 to 50,000 inhabitants. The remaining four national bank charters were granted for banks in communities with populations ranging from 1,000 to 5,000 .

III. Savings Banks and Unincorporated Banks in Ohio

A. Savings Banks

On December 31,1945 there were three mutual savings banks operating in Ohio. The three mutual savings banks in ohio in 1945 were The Society for Savings in Cleveland, The Springfield Savings Society in Springfield, and The Dime Savings Society in Marietta. 
On December 31, 1959 only the mutual savings banks located in Springfield and Marietta remained in operation. 7

$7_{\text {American Bank Directory (Atlanta, Ga,: McFadden Business }}$ Pub1ications, 1946 and 1960).

The mutual savings banks in Ohio operate under charters granted by the state of Ohio, and they are subject to regulation by the onio Superintendent of Banks. 8 Until 1955 the mutual savings banks

OChio Banking Laws Annotated, 1109.02.

accepted both time and demand deposits, but in that year an amendment to Ohio law was passed which expressly forbid these organizations from accepting demand deposits, and 1 t allowed them to form or acquire comercial banks to which existing demand deposits were transferred. 9

$9_{\text {Ibid., } 1109.05 .}$

In addition to mutual savings banks, the Ohio banking law al so provides for the formation of stock savings banks. 10 The ohio

$$
{ }^{10} \text { Ibid., } 1101.01 .
$$

Superintendent of Banks reported that there are no longer any stock savings banks in operation in Ohio. All Ohlo stock savings banks have elther passed out of existence, or they have amended the purpose 
clause in their corporate charter to allow the bank to engage in a commercial banking business. Many of these banks retain the name "savings bank," but they do not differ from any other commercial banking operation. 11

\footnotetext{
1961.

${ }^{11}$ Interview with the Ohio Superintendent of Banks, March 24 ,
} B. Unincorporated Banks

Table 41 (see Appendix) presents the number and total assets of unincorporated banks that have been in operation in ohio during the postwar period. The last unincorporated bank in Ohlo underwent voluntary 1iquidation in August of 1956.12

120. E. Anderson, "Chang1ng Times End Ohio's Last Private Bank," The Ohio Banker, August, 1956, p. 12.

Since 1919 onlo law has forbidden the formation of unincorporated banks, but those in operation prior to that date were allowed to continue operation.

No authority to transact a banking business in this state shall be granted except to corporations organized and qualified for that purpose. Unincorporated banks authorized to transact and actually transacting a banking business on July 12, 1919, may continue such banking business in the municipal corporation or township in which they were located so long as they comply with Chapters 
$1101,1103,1105,1107,1109,1111,1113,1115$, of the Revised Code. 13

\section{${ }^{13}$ Onio Banking Laws Annotated, 1115,02 .}

IV. Geographic Dispersion of Banks in Ohie

Table 42 (see Appendix) presents the number of state and national banks in each of Ohio's 88 counties in 1945 and in 1959.

During that 14-year period, 32 of Ohio's counties maintained the same number of banks as they had in 1945. In 16 countles the mmber of banks increased, and in 40 countles the number of banks declined.

In the 32 countles where the number of banks did not change during the pestwar period, all but two of these countles maintalned the same ratio of state and national banks as they had in 1945. Only Columblana and Harrison Counties had a change in the ratio of state and national banks, and both of these counties gained an additional national bank while losing a state chartered institution.

Among the 16 ohlo counties that had an increase in the number of banks during the postwar period, 13 recelved one additional bank. The remaining three counties each gained two additional banks. The 19 additional banks formed in these 16 counties were evenly divided between state and national banks.

The 40 Ohio counties which had a reduction in the maber of banks in operation lost a total of 102 banks. A total of 17 counties 
lost one bank each, 11 counties lost two banks each, and the remaining 12 counties lost three or more banks each. Hamilton County led with a decline of 17 banks during the postwar period.

During the entire postwar period, Ohio did not have a single county without a bank. The Federal Deposit Insurance Corporation reports that in June of 1958 there were only 62 counties in the United States without banking facilities. 14 In 1945, however, Ohfo had two

14 Division of Research and Statistics, Changes in the Number of Banking Offices, 1859-1958, and in Banking Concentration 1921-1958 (Washington, D.C.: Federal Deposit Insurance Corporation, 1961), p. 19.

counties with only one bank in operation, and the situation remained the same in 1959, although the particular counties had changed.

In 1945 there were seven Ohio counties without a national bank, and five counties without the services of a state chartered bank. By 1959 only five Ohio counties did not contain a national bank, and only three counties remalned without a state bank.

Hamiton county, in 1945 , led all onio counties with a total of 28 banks composed of 18 state banks and 10 national banks. By 1959, however, Hamilton County had been replaced by Frank1in County which supported a total of 16 banks composed of 12 state banks and four national banks. 
V. Federal Deposit Insurance Corporation and Federal Reserve Membership Among Ohio Banks

Table 6 presents the number of banks in Ohio which were members of the Federal Deposit Insurance Corporation during the postwar period, and the number of banks which were unable to qualify for membership or elected to remain a noninsured bank.

Every commerclal bank operating under a national bank charter and each state chartered bank holding membership in the Federal Reserve System must maintain membership in the Federal Deposit Insurance Corporation.

Every national member bank which is authorized to commence or resume the business of banking, and which is encaged in the business of recelving deposits other than trust funds as herein defined, and every such national nonmember bank which becomes a member of the Federal Reserve system, and every state bank which is converted into a national bank or which becomes a member of the Federal Reserve system, and which is engaged in the business of receiving deposits, other than truwt funds as herefn defined shall be an insured bank from the time it is authorized to commence or resume business or becomes a member of the Federal Reserve system. 15

15 Federal Code Annotated, Title 12, Section 1814 .

In 1945 there were 15 banks in Ohio which did not hold membership in the Federal Deposit insurance Corporation. These 15 banks comprised 2.2 per cent of the total number of banks in Ohlo. Of these 15 noninsured banks in Ohio, seven were unincorporated banks which were not eligible for membership. ${ }^{16}$ By 1959, however, only one bank

$$
\text { 16 Ib1d., Title 12, Sec. } 1814 \text {. }
$$


TABLE 6

NUMBER OF BANKS IN OHIO WITH MEMBERSHIP

IN THE FEDERAL DEPOSIT INSURANCE CORPORATION

$1945-1959$

\begin{tabular}{|c|c|c|}
\hline Year & $\begin{array}{l}\text { Number of } \\
\text { Banks in Ohio } \\
\text { with F.D.I.C. } \\
\text { Membership }\end{array}$ & $\begin{array}{c}\text { Number of } \\
\text { Banks in Ohio } \\
\text { without F.D.I.C. } \\
\text { Membership }\end{array}$ \\
\hline 1945 & 662 & 15 \\
\hline 1946 & 659 & 15 \\
\hline $19 \Lambda_{4} 7$ & 654 & 14 \\
\hline 1948 & 653 & 13 \\
\hline 1949 & 649 & 12 \\
\hline 1950 & 650 & 9 \\
\hline 1951 & 649 & 7 \\
\hline 1952 & 644 & 7 \\
\hline 1953 & 638 & 6 \\
\hline 1954 & 631 & 5 \\
\hline 1955 & 620 & 3 \\
\hline 1956 & 615 & 2 \\
\hline 1957 & 610 & 1 \\
\hline 1958 & 605 & 1 \\
\hline 1959 & 587 & 1 \\
\hline
\end{tabular}


In Ohio remained without Federal Deposit Insurance membership. The noninsured bank, on December 31, 1959, held total deposits of $\$ 1,827,000.17$

\section{Amerlcan Bank Directory, 1960, p. 2006.}

Although the state chartered banks which do not hold a membership in the Federal Reserve System are not legally compelled to become insured banks, the Ohio Division of Banks encourages membership in the Federal Deposit Insurance Corporation, and new state bank charters are not granted until the applicant has been approved for F.D.I.C. membership. ${ }^{18}$

\footnotetext{
${ }^{18}$ Interview with the Ohio Superintendent of Banks, March 24, 1961.

B. Federal Reserve Member Eanks

Many banks in Ohio maintain membership in the Federal Reserve System in addition to membership in the Federal Deposit Insurance Corporation. Table 7 presents the number and percentage of banks in Ohio which were Federal Reserve member banks from 1945 to 1959 , and the number of and percentage of state chartered banks in ohto which held membership in the Federal Reserve System.
} 


\section{TABLE 7}

NUMBER OF BANKS IN OHIO HITH MEMBERSHIP

IN THE FEDERAL RESERVE SYSTEM

$1945-1959$

\begin{tabular}{lcccc}
\hline Year & $\begin{array}{c}\text { Total Number } \\
\text { of Banks in } \\
\text { Ohi o with } \\
\begin{array}{c}\text { Federal Reserve } \\
\text { Membersh1p }\end{array}\end{array}$ & $\begin{array}{c}\text { Federal Reserve } \\
\text { Member Banks } \\
\text { as Per cent } \\
\text { of Total } \\
\text { Banks in Ohi }\end{array}$ & $\begin{array}{c}\text { Total Number } \\
\text { of Ohio State } \\
\text { Banks wi th } \\
\text { Federal Reserve } \\
\text { Membership }\end{array}$ & $\begin{array}{c}\text { State Member } \\
\text { Banks as a } \\
\text { Per cent of } \\
\text { Total State } \\
\text { Banks in Onio }\end{array}$ \\
\hline 1945 & 424 & 62.6 & 184 & 42.1 \\
1946 & 426 & 63.2 & 187 & 43.0 \\
1947 & 424 & 63.4 & 184 & 42.9 \\
1948 & 425 & 63.8 & 184 & 43.3 \\
1949 & 424 & 64.1 & 183 & 43.6 \\
1950 & 420 & 63.7 & 181 & 43.1 \\
1951 & 419 & 63.9 & 180 & 43.3 \\
1952 & 417 & 64.1 & 179 & 43.3 \\
1953 & 412 & 64.0 & 177 & 43.5 \\
1954 & 412 & 65.0 & 173 & 43.3 \\
1955 & 401 & 64.4 & 171 & 43.5 \\
1956 & 395 & 64.0 & 166 & 42.8 \\
1957 & 391 & 64.0 & 162 & 42.4 \\
1958 & 385 & 63.5 & 157 & 41.5 \\
1959 & 373 & 63.4 & 151 & 4.3 \\
\hline
\end{tabular}

Source: Annual Report of the Federal Deposit Insurance Corporation, $1945-1959$. 
Banks which have recelved their charter from the Comptroller of the Currency are required to become members of the Federal Reserve System.

Every national banking association wi thin each Federal Reserve district shall be required to subscr tbe to the capital stock of the Federal Reserve Bank for that district in a sum equal to 6 per centum of the pald up capital stock and surplus of such banks. . . 19

19 Federal Code Annotated, Title 12, Sec. 278.

Banks in Ohio which have received their charter from the State of Ohio may become a member of the Federal Reserve System if they are able to meet the recuirements for membership. 20

${ }^{20}$ Ohlo Banking Laws Annotated, 1105.02.

Table 7 reveals that 42.1 per cent of the state banks in onlo were nembers of the Federal Reserve System in 1945, and in 1959 the percentage had declined to 41.3 per cent. As a percentage of total banks in Ohio, membership in the Federal Reserve System was 62.6 per cent in 1945 and 63.4 per cent in 1959. The slight increase in Federal Reserve membership among all banks in Ohio is due to the Increase in the total number of banks in Ohio which operate under a natlonal charter.

VI. Financial Structure of Banks in Ohio Table 8 presents the total assets and average assets of a11 banks, national banks, and state banks for the perlod 1945 to 1959. 
TABLE 8

TOTAL AND AVERAGE ASSETS OF ALL BANKS, NATIONAL BANKS, AND STATE BANKS IN OHIO

1945-1959

(Thousands of Dollars)

\begin{tabular}{|c|c|c|c|c|c|c|}
\hline Year & $\begin{array}{c}\text { Al1 } \\
\text { Banks }\end{array}$ & $\begin{array}{l}\text { Total Assets } \\
\text { Dational } \\
\text { Banks }\end{array}$ & $\begin{array}{l}\text { State } \\
\text { Benks }\end{array}$ & $\begin{array}{l}\text { All Bank } \\
\text { Average }\end{array}$ & $\begin{array}{l}\text { Average Asset } \\
\text { National Bank } \\
\text { Average }\end{array}$ & $\begin{array}{c}\text { State bank } \\
\text { Average }\end{array}$ \\
\hline 1945 & $\$ 7,826,542$ & $\$ 3,418,938$ & $\$ 4,181,411$ & $\$ 11,559$ & $\$ 14,246$ & $\$ 9,567$ \\
\hline 1946 & $7,423,536$ & $2,192,656$ & $3,893,657$ & 11,015 & 9,176 & 8,952 \\
\hline 1947 & $7,663,443$ & $3,504,304$ & $3,903,678$ & 11,471 & 14,600 & 9,121 \\
\hline 1948 & $7,848,118$ & $3,625,255$ & $3,968,099$ & 11,780 & 15,041 & 9,336 \\
\hline 1949 & $8,021,377$ & $3,707,600$ & $4,052,941$ & 12,131 & 15,386 & 9,650 \\
\hline 1950 & $8,664,410$ & $4,025,022$ & $4,371,075$ & 13,154 & 16,701 & 10,457 \\
\hline 1951 & $9,234,434$ & $4,342,333$ & $4,613,301$ & 14,087 & 18,167 & 11,062 \\
\hline 1952 & $9,758,114$ & $4,604,380$ & $4,862,124$ & 14,990 & 19,345 & 11,772 \\
\hline 1953 & $10,214,975$ & $4,814,268$ & $5,074,364$ & 15,863 & 20,485 & 12,406 \\
\hline 1954 & $10,465,872$ & $4,948,951$ & $5,116,796$ & 16,508 & 21,149 & 12,093 \\
\hline
\end{tabular}


TABLE 8 (continued)

\begin{tabular}{|c|c|c|c|c|c|c|}
\hline \multirow[b]{2}{*}{ Year } & \multicolumn{3}{|c|}{ Total Assets } & \multicolumn{3}{|c|}{ Average Assets } \\
\hline & $\begin{array}{c}\text { A11 } \\
\text { Banks }\end{array}$ & $\begin{array}{l}\text { Nat1 one1 } \\
\text { Banks }\end{array}$ & $\begin{array}{l}\text { State } \\
\text { Banks }\end{array}$ & $\begin{array}{l}\text { A11 Bank } \\
\text { Average }\end{array}$ & $\begin{array}{l}\text { National Bank } \\
\text { Average }\end{array}$ & $\begin{array}{c}\text { State Bank } \\
\text { Average }\end{array}$ \\
\hline 1955 & $\$ 11,020,885$ & $\$ 5,175,081$ & $\$ 5,439,498$ & $\$ 17,690$ & 22,500 & $\$ 13,840$ \\
\hline 1956 & $11,383,465$ & $5,425,184$ & $5,602,573$ & 18,448 & 23,690 & $14,441$. \\
\hline 1957 & $11,567,500$ & $5,552,658$ & $5,666,693$ & 18,933 & 24,249 & 14,835 \\
\hline 1958 & $11,932,386$ & $5,825,371$ & $5,758,166$ & 19,690 & 25,548 & 15,233 \\
\hline 1959 & $12,177,944$ & $6,307,854$ & $5,839,514$ & 20,711 & 28,414 & 15,956 \\
\hline
\end{tabular}

Source: Annual Report of the Comptroller of the Currency, 1946-1960, and Annual Report of the Federal Deposit Insurance Corporation, 1945-1959. 
A. Growth and Distribution of Bank Assets in Ohio

The total bank assets in Chio increased $\$ 4,351,402$ during the postwar period. The increase in bank assets during the 14-year period represented 5.5 per cent of the total bank assets in Ohio in 1945.

The total bank assets in Ohio expanded most rapidly between 1950 and 1955. During this five-year period 53.9 per cent of the entire postwar expansion in bank assets in ohio took place.

As a result of the decline in the number of total banks in onio and the increase in total bank assets, the average assets size of all banks in Ohio increased by 80.4 per cent. The average bank asset size grew from $\$ 11,559,000$ in 1945 to $\$ 20,711,000$ in 1959 .

\section{National Banks}

National banks in Ohio, as a group, increased their total assets more than state banks in Ohio during the postwar period. Fram 1945 to 1959 national banks in the state increased their total assets by 84.5 per cent, and the proportion of total bank assets in ohio under the contro1 of national banks increased from 43.6 per cent in 1945 to 51.8 per cent in 1959.

The average asset size of national banks in Ohio Increased by 99.5 per cent during the subject perlod. In 1945 the average asset size of national banks in ohio was $\$ 14,246,000$ which was 23.2 per cent larger than the all bank average in Ohio. By 1959 the average 
asset size of national banks had increased to $\$ 28,414,000$ which exceeded the all bank average in Ohio by 37.1 per cent. 2. State Banks

The total assets of state banks in Ohio Increased by 39.6 per cent in the postwar period; however, state bank assets declined from 53.2 per cent of total bank assets in ohio in 1945 to 47.9 per cent in 1959.

The average asset size of Ohio state banks expanded by 85.6 per cent from 1945 to 1959. Again, however, state banks failed to keep pace with the rate of growth of national banks in Ohio. In 1945 the average asset size of state banks was 17.5 per cent below the all bant average in ohio, and in 1959 the gap had widened to 22.9 per cent.

\section{B. Conposition of Total Bank Assets in Ohio}

Table 9 presents the distribution of total bank assets in Ohio among the major asset categories from 1945 to 1959. 1. Loans and Discounts

The total loans of banks in Ohio have increased as a proportion of total assets in every year of the postwar perlod with the exception of 1957 and 1958. During the postwar period total loans of banks in Ohio Increased from 16.5 per cent to 44.6 per cent of total assets.

2. United States Goverment Obligations

The proportion of total assets held in the form of United States governent obligations declined from 58.2 per cent of total assets 
TABLE 9

COMPOSITION OF TOTAL ASSETS OF ALL BANKS IN OHIO

1945-1959

(Thousands of Dollars)

\begin{tabular}{|c|c|c|c|c|c|c|c|c|c|c|}
\hline Year & $\begin{array}{l}\text { Loans and } \\
\text { Di scounts }\end{array}$ & $\begin{array}{l}\text { Per } \\
\text { cent } \\
\text { of } \\
\text { Total }\end{array}$ & $\begin{array}{l}\text { United } \\
\text { States } \\
\text { Government } \\
\text { Obligat lons }\end{array}$ & $\begin{array}{l}\text { Per } \\
\text { cent } \\
\text { of } \\
\text { Total }\end{array}$ & $\begin{array}{l}\text { Obligations } \\
\text { of State } \\
\text { and Local } \\
\text { Governments }\end{array}$ & $\begin{array}{l}\text { Per } \\
\text { cent } \\
\text { of } \\
\text { Total }\end{array}$ & $\begin{array}{l}\text { Balances with } \\
\text { Other Banks } \\
\text { and Federal } \\
\text { Reserve Banks }\end{array}$ & $\begin{array}{l}\text { Per } \\
\text { cent } \\
\text { of } \\
\text { Total }\end{array}$ & $\begin{array}{c}\text { A11 } \\
\text { Other } \\
\text { Assets }\end{array}$ & $\begin{array}{l}\text { Per } \\
\text { cent } \\
\text { A11 } \\
\text { Assets }\end{array}$ \\
\hline 1945 & $\$ 1,292,405$ & 16.5 & $\$ 4,554,102$ & 58.2 & $\$ 213,211$ & 2.7 & $\$ 1,386,205$ & 17.5 & $\$ 380,619$ & 5.1 \\
\hline 1946 & $1,565,466$ & 21.1 & $3,758,098$ & 51.0 & 246,589 & 3.3 & $1,424,696$ & 19.1 & 428,687 & 5.5 \\
\hline 1947 & $1,869,712$ & 24.4 & $3,502,325$ & 45.7 & 299,514 & 3.9 & $1,577,400$ & 20.6 & 415,492 & 5.4 \\
\hline 1948 & $1,982,271$ & 25.3 & $3,495,897$ & 4.5 & 321,807 & L.1 & $1,616,665$ & 20.6 & 431,478 & 5.5 \\
\hline 1949 & $2,041,980$ & 25.4 & $3,758,801$ & 46.8 & 331,883 & 4.1 & $1,448,236$ & 18.0 & 490,477 & 5.7 \\
\hline 1950 & $2,504,369$ & 28.9 & $3,524,747$ & 40.7 & 406,665 & 4.7 & $1,737,540$ & 20.1 & 491,089 & 5.6 \\
\hline 1951 & $2,770,628$ & 30.0 & $3,610,853$ & 39.1 & 478,556 & 5.2 & $1,867,809$ & 20.2 & 506,588 & 5.5 \\
\hline 1952 & $3,090,162$ & 31.7 & $3,784,621$ & 38.8 & 524,411 & 5.14 & $1,863,261$ & 19.1 & 485,659 & 5.0 \\
\hline 1953 & $3,382,046$ & 33.1 & $3,810,420$ & $37 \cdot 3$ & 575,116 & 5.6 & $1,983,697$ & 19.4 & 453,696 & 4.6 \\
\hline 1954 & $3,506,788$ & 33.5 & $4,036,279$ & 38.6 & 615,252 & 5.9 & $1,860,608$ & 17.7 & 446,945 & 4.3 \\
\hline
\end{tabular}


TABLE 9 (continued)

\begin{tabular}{|c|c|c|c|c|c|c|c|c|c|c|c|}
\hline Yeạr & $\begin{array}{l}\text { Loans and } \\
\text { Di scounts }\end{array}$ & $\begin{array}{l}\text { Per } \\
\text { cent } \\
\text { of } \\
\text { Total }\end{array}$ & $\begin{array}{l}\text { United } \\
\text { States } \\
\text { Government } \\
\text { Obligations }\end{array}$ & $\begin{array}{l}\text { Per } \\
\text { cent } \\
\text { of } \\
\text { Total }\end{array}$ & $\begin{array}{l}\text { Obligations } \\
\text { of State } \\
\text { and Local } \\
\text { Governments }\end{array}$ & $\begin{array}{l}\text { Per } \\
\text { cent } \\
\text { of } \\
\text { Total }\end{array}$ & & $\begin{array}{l}\text { ances with } \\
\text { Dther Banks } \\
\text { and Federal } \\
\text { eserve Banks }\end{array}$ & $\begin{array}{l}\text { Per } \\
\text { cent } \\
\text { of } \\
\text { Total }\end{array}$ & $\begin{array}{l}\text { All } \\
\text { Other } \\
\text { Assets }\end{array}$ & $\begin{array}{l}\text { Per } \\
\text { cent } \\
\text { Al1 } \\
\text { Assets }\end{array}$ \\
\hline 1955 & $\$ 4,090,056$ & 37.1 & $\$ 3,777,772$ & 34.3 & $\$ 633,823$ & 5.8 & $\$$ & $2,010,317$ & 28.2 & $\$ 508,917$ & 4.6 \\
\hline 1956 & $4,575,785$ & 41.8 & $3,401,053$ & 30.7 & 650,158 & 5.7 & & $2,135,773$ & 18.7 & 620,696 & 4.1 \\
\hline 1957 & $4,821,064$ & 41.7 & $3,445,449$ & 29.9 & 708,135 & 6.1 & & $2,023,989$ & 17.5 & 568,863 & 4.8 \\
\hline 1958 & $4,931,807$ & 41.3 & $3,714,185$ & 31.1 & 761,367 & 6.4 & & $1,975,642$ & 16.5 & 549,385 & 4.7 \\
\hline 1959 & $5,434,698$ & 44.6 & $3,386,902$ & 27.8 & 801,830 & 6.5 & & $2,056,813$ & 16.9 & 497,701 & 4.2 \\
\hline
\end{tabular}

Source: Annual Report of the Comptroller of the Currency, 1946-1960. 
in 1945 to 27.8 per cent in 1959. The value of United States government obligations held by all banks in Ohio from 1945 to 1959 also declined by 25.6 per cent.

3. State and Local Government Obligations

Unlike United States government obligations, the total value of state and local government obligations held by banks in Ohio increased by 275 per cent from 1945 to 1959 . The proportion of total assets represented by state and local government obligations is, however, still smal1. In 1945 state and bcal government obligations represented only 2.7 per cent of total bank assets in Ohio, and In 1959 the proportion increased to 6.5 per cent of total assets.

1. Balances with Other Banks and the Federal Reserve Bank

As a proportion of total assets of all banks in Ohio the balancee maintained with correspondent banks and the Federal Reserve Bank of Cleveland remained between 16 and 20 per cent of total assets during the entire postwar period.

\section{Al1 Other Assets}

The "all other" assets category includes other investment securfties held by banks in Ohio, currency and coin, and bank real estate and premises. As a proportion of total assets, "other assets" demonstrated a decline from 5.1 per cent of assets in 1945 to 4.2 per cent in 1959. 
C. Distribution of Bank Loans in Ohio

Table 43 (see Appendix) presents the amount of total loans of all banks in Ohio and the proportion of the total held by national and state banks during the postwar period.

From 1945 to 1959 total bank loans in Ohio increased 320 per cent. The increase was not uniform, however, during the entire $14-y e a r$ period. The initial five-year period provided the most rapld rate of growth when the total loans of a 11 banks in onio increased 93.8 per cent. In the next five years, 1950 to 1955 , the rate of expansion of loans declined to 62.9 per cent, and in the final four years of the subject perlod, total loans increased 32.8 per cent.

\section{National Banks}

In $1945,42.5$ per cent of a 11 bank loans in Ohlo were controlled by national banks, and in 1959 the national bank share had expanded to 50.0 per cent. This increase in the proportion of total loans held by national banks was a result of the 394 per cent increase in the value of national bank loans in ohio, and the smaller increase in state bank loans during the same period.

\section{State Banks}

State chartered banks in Ohlo Increased their total loans by 300 per cent during the postwar period, but the proportion of total bank loans controlled by state banks was reduced from 52.5 per cent in 1945 to 50.0 per cent in 1959. 


\section{Composition of Bank Loans in Ohio}

Table 44 (see Appendix) presents the total bank bans in ohio by the major categories of loans held during the postwar period.

1. Comnercial and Industrial Loans

The commerclal and Industrial loans of banks in Ohio Increased by $\$ 1,057,906,000$ from 1945 to 1959 . As a percentage of total loans, conmercial and Incustrial loans ranged from 23.3 per cent in 1945 to 33.3 in 1947, and in 1959 they represented 27.2 per cent of total loans. The amount of commercial and industrial loans increased substantially during the period, but it appears to have become a rather stable proportion of total loans.

One reason for the lack of more pronounced growth in the proportion of total loans assigned to commercial and industrial borrowers is the alternative sources of supply that have become available to these borrowers during the postwar period.

While the traditional division of the financial markets between commercial banks and the securities markets has been between short- and long-term credit, there is much evidence that size is a more Important point of difference. Those big enough to have a "name" in the central capital markets finance themselves in these markets whether their needs are long-term or short-term. Those who cannot command credit in the central capltal markets content themselves with bank credit and adjust their affairs so that short-term borrowIngs fill their needs, even though they might, with more cholces at their command, prefer long-term credit. 20

20 Roland I. Robinson, Management of Bank Funds (New York: MoGraw-Hil1 Book Company, Inc., 1951), p. 100. 
2. Loans to Brokers and Dealers and Loans for the Purchase of SecuritTes

Loans to brokers and dealers and loans for the purchase of securities declined sharply as a proportion of total loans during the postwar period. In 1945 this category of loans represented 28.7 per cent of the total loans of a 11 banks in Ohio, and by 1959 it had been reduced to 5.8 per cent of the total. The greatest decline took place in the two years immediately following the end of World War II.

\section{Rea1 estate Loans}

Total real estate loans include farm real estate, non-farm residential real estate, as well as industrial and commerclal real estate loans. The total real estate loans of all banks in Ohio during the postwar period ranged from 28.9 per cent to 39.5 per cent of total loans. In 1959, real estate loans accounted for 33.3 per cent of total loans, and they served as the largest single category of bank loans in Ohio. The banis in Ohio increased the amount of real estate loans outstanding from $\$ 347,339,000$ in 1945 to $\$ 1,948,559,000$ in 1959 .

Much of the increase in real estate 1 oans by banks throughout the United States resulted from the increase in loans to real estate firms and mortgage companies. ${ }^{21}$ Unfortunately, statistics concerning loans of this type by banks in Ohio are not avallable.

\section{1 "Business Loans of Member Banks," Federal Reserve Bulletin} (washington, D.C.: Federal Reserve Board of Governors, Apr11, 1956), p. 329. 
4. Other Loans to Individuals

Other loans to Individuals are composed primarily of consumer instalment loans. As a proportion of total loans, this category has had the most rapid growth. In 1945 other loans to individuals accounted for only 9.7 per cent of total loans, but in 1959, 23.0 per cent of total loans were in the form of other loans to individuals. The largest expansion in this category took place between 1945 and 1950. During the total postwar period the increase in other loans to Individuals totaled $\$ 1,699,907,000$.

5. Other Loans

The other loans category is composed of loans to farmers, loans to other banks and flnancial institutions, and a number of mIscellaneous loans including overdrafts. As a total, other loans has been a stable proportion of total bank loans in Ohio. The increase in the other loans category in 1959 from 6.2 to 10.7 per cent, however, is a result of an increase in loans to other financial institutions, 22

22 Annual Report of the Comptroller of the Currency, 1959.

$$
\text { E. Bank Deposits in Ohio }
$$

Table 10 presents the total deposits of all banks in Ohio and the division of total deposits between national and state banks. Tables 11 and 12 present the demand and time deposits for all banks, national banks, and state banks in Ohio. 
TABLE 10

TOTAL DEPOSITS OF ALL BANKS, NATIONAL BANKS, AND STATE BANKS IN OHIO

19L5-1959

(Thousands of Dollars)

\begin{tabular}{cccc}
\hline Year & $\begin{array}{c}\text { Al1 } \\
\text { Banks }\end{array}$ & $\begin{array}{c}\text { National } \\
\text { Banks }\end{array}$ & $\begin{array}{c}\text { State } \\
\text { Banks }\end{array}$ \\
\hline 1945 & $\$ 7,389,965$ & $\$ 3,224,830$ & $\$ 3,955,198$ \\
1946 & $6,954,093$ & $2,982,343$ & $3,742,816$ \\
1947 & $7,178,404$ & $3,274,753$ & $3,667,072$ \\
1948 & $7,346,038$ & $3,385,925$ & $3,722,492$ \\
1949 & $7,491,816$ & $3,458,865$ & $3,790,562$ \\
1950 & $8,082,933$ & $3,756,384$ & $4,078,538$ \\
1951 & $8,609,130$ & $4,056,077$ & $4,296,884$ \\
1952 & $9,077,075$ & $4,288,187$ & $4,520,960$ \\
1953 & $9,483,162$ & $4,468,989$ & $4,712,506$ \\
1954 & $9,686,705$ & $4,574,971$ & $4,470,604$ \\
1955 & $10,200,430$ & $4,778,620$ & $5,045,409$ \\
1956 & $10,485,857$ & $4,998,310$ & $5,173,405$ \\
1957 & $10,589,593$ & $5,068,860$ & $5,203,569$ \\
1958 & $10,897,381$ & $5,312,326$ & $5,267,068$ \\
1959 & $11,055,875$ & $5,710,033$ & $5,318,277$ \\
\hline
\end{tabular}

Source: Annual Report of the Comptroller of the Currency, 1946-1960. 
TABLE 11

TOTAL DEMAND DEPOSITS OF ALL BANKS,

NATIONAL BANKS, AND STATE BANKS IN OHIO

1945-1959

(Thousands of Dollars)

\begin{tabular}{cccccccc}
\hline Year & $\begin{array}{c}\text { Al1 } \\
\text { Banks }\end{array}$ & $\begin{array}{c}\text { Per cent } \\
\text { of } \\
\text { Total } \\
\text { Deposits }\end{array}$ & $\begin{array}{c}\text { National } \\
\text { Banks }\end{array}$ & $\begin{array}{c}\text { Per cent } \\
\text { of } \\
\text { Total } \\
\text { Deposits }\end{array}$ & $\begin{array}{c}\text { State } \\
\text { Banks }\end{array}$ & $\begin{array}{c}\text { Per cent } \\
\text { of } \\
\text { Total } \\
\text { Deposits }\end{array}$ \\
\hline 1945 & $4,942,029$ & 66.9 & $2,407,576$ & 74.6 & $2,530,268$ & 63.9 \\
1946 & $4,250,629$ & 61.1 & $2,076,085$ & 69.5 & $2,169,997$ & 57.9 \\
1947 & $4,362,007$ & 60.7 & $2,260,756$ & 69.0 & $2,069,962$ & 57.1 \\
1948 & $4,469,396$ & 60.8 & $2,339,911$ & 69.2 & $2,125,692$ & 57.1 \\
1949 & $4,609,361$ & 61.5 & $2,421,044$ & 69.9 & $2,184,180$ & 57.6 \\
1950 & $5,213,170$ & 65.3 & $2,718,332$ & 72.3 & $2,489,819$ & 60.9 \\
1951 & $5,618,501$ & 65.5 & $2,957,112$ & 72.9 & $2,657,063$ & 61.8 \\
1952 & $5,958,815$ & 64.4 & $3,141,520$ & 73.2 & $2,807,636$ & 61.8 \\
1953 & $6,107,052$ & 63.1 & $3,236,761$ & 72.4 & $2,857,346$ & 60.6 \\
1954 & $6,112,763$ & 63.4 & $3,252,060$ & 71.0 & $2,830,874$ & 63.3 \\
1955 & $6,529,822$ & 64.0 & $3,433,763$ & 71.8 & $3,055,783$ & 60.5 \\
1956 & $6,723,756$ & 64.1 & $3,582,661$ & 71.2 & $3,140,635$ & 60.7 \\
1957 & $6,669,055$ & 62.9 & $3,578,525$ & 70.5 & $3,090,155$ & 59.3 \\
1958 & $6,771,430$ & 62.1 & $3,705,415$ & 69.7 & $3,064,991$ & 57.2 \\
1959 & $6,810,311$ & 61.5 & $3,733,416$ & 65.3 & $3,076,826$ & 57.4 \\
\hline & 504969 & & & & & &
\end{tabular}

19L6-1960.

Source: Annual Report of the Comptroller of the Currency, 
TABLE 12

TOTAL TIME DEPOSITS OF ALL, BANKS

NATIONAL BANKS, AND STATE BANKS IN OHIO

1945-1959

(Thousands of Dollars)

\begin{tabular}{|c|c|c|c|c|c|c|}
\hline Year & $\begin{array}{c}\text { All } \\
\text { Banks }\end{array}$ & $\begin{array}{c}\text { Per cent } \\
\text { of } \\
\text { Tota1 } \\
\text { Deposits }\end{array}$ & $\begin{array}{l}\text { National } \\
\text { Banks }\end{array}$ & $\begin{array}{c}\text { Per cent } \\
\text { of } \\
\text { Total } \\
\text { Deposits }\end{array}$ & $\begin{array}{l}\text { State } \\
\text { Banks }\end{array}$ & $\begin{array}{c}\text { Per cent } \\
\text { of } \\
\text { Tota1 } \\
\text { Deposits }\end{array}$ \\
\hline 1945 & $\$ 2,447,936$ & 33.1 & 817,254 & 25.4 & $\$ 1,424,930$ & 36.1 \\
\hline 1946 & $2,703,464$ & 38.9 & 906,258 & 30.5 & $1,572,819$ & 42.1 \\
\hline 1947 & $2,816,397$ & 39.3 & $1,013,997$ & 31.0 & $1,570,110$ & 42.9 \\
\hline 1948 & $2,878,642$ & 39.2 & $1,046,014$ & 30.8 & $1,596,800$ & 42.9 \\
\hline 1949 & $2,882,455$ & 38.5 & $1,037,821$ & 30.1 & $1,606,382$ & 42.4 \\
\hline 1950 & $2,869,763$ & 34.7 & $1,038,052$ & 27.7 & $1,588,719$ & 39.1 \\
\hline 1951 & $2,990,629$ & 34.5 & $1,098,965$ & 27.1 & $1,639,971$ & 32.2 \\
\hline 1952 & $3,118,260$ & 35.6 & $1,146,667$ & 26.8 & $1,713,324$ & 32.2 \\
\hline 1953 & $3,376,110$ & 36.9 & $1,232,228$ & 27.6 & $1,855,160$ & 39.4 \\
\hline 1954 & $3,573,942$ & 36.6 & $1,322,911$ & 29.0 & $1,909,730$ & 36.7 \\
\hline 1955 & $3,670,608$ & 36.0 & $1,344,857$ & 28.2 & $1,979,620$ & 39.5 \\
\hline 1956 & $3,762,101$ & 35.9 & $1,405,335$ & 28.8 & $2,032,770$ & 39.3 \\
\hline 1957 & $3,919,538$ & 37.1 & $1,490,335$ & 25.5 & $2,113,414$ & 40.7 \\
\hline 1958 & $4,125,951$ & 37.9 & $1,606,911$ & 30.3 & $2,202,077$ & 42.8 \\
\hline 1959 & $4,254,564$ & 38.5 & $1,976,617$ & 34.7 & $2,241,451$ & 42.6 \\
\hline
\end{tabular}
1960.

Source: Annual Report of the Comptroller of the Currency, 1946- 
The proportion of total deposits represented by time deposits Increased from 33.1 per cent in 1945 to 38.5 per cent in 1959. One important reason for the postwar growth in time deposits was the Federal Reserve Board rulling in the latter part of 1956 increasing the maximum interest member banks could pay from 2.5 per cent to 3 per cent on savings deposits and time deposits having a maturity date of six months or more. ${ }^{23}$

${ }^{23}$ Supplement to Regulation Q., Board of Governors of the Federal Reserve System, Jamuary 1, 1957.

Although demand deposits have never represented less than 60 per cent of the total deposits of banks in Ohio during the postwar period, the increase in demand deposits during the same period exceeded the increase in time deposits by a rather narrow margin of 3.2 per cent.

2. Deposits of National Banks

National banks operating in Ohio increased their total deposits by 77.0 per cent during the postwar period. The proportion of total bank deposits in onio held by national banks rose from 43.6 per cent in 1945 to 51.6 per cent in 1959.

During the postwar period the national banks in Ohio held a larger proportion of their total deposits in the form of demand deposits than the state banks. In $1945,74.6$ per cent of total national bank deposits were demand deposits; however, by 1959 demand depoutts represented only 65.3 per cent of the total deposits of 
national banks in the state. In $1959,54.6$ per cent of the total demand deposits in ohto were maintalned in national banks.

Mational banks held a larger proportion of total time deposits in Ohio in 1959 than in 1945. In 1945, 33.3 per cent of total time deposits in banks in Ohlo were deposited in national banks, and by 1959 the national banks had increased their share to 46.3 per cent of the total.

2. State Baniks

State chartered banks operating in ohio increased their total deposits 36.9 per cent from 1945 to 1959 . This deposit growth was, of course, substantially below the increase of deposits in national banks.

State banks throughout the subject perfod maintained a much smaller proportion of their total deposits in the form of demand deposits than the national banks in Chio. In 1945, 66.9 per cent of state bank deposits were demand deposits, but in 1959 only 61.5 per cent of their total deposits were payable on demand.

F. Growth and Distribution of Bank Capital in Ohio

Table 13 presents the total capital of banks in Ohto, and the distribution of the total between national and state banks during the postwar period. 
TABLE 13

TOTAL CAPITAL OF ALL BANKS IN OHIO

1945-1959

(Thousands of Dollars)

\begin{tabular}{|c|c|c|c|c|c|c|}
\hline Year & A11 Banks & $\begin{array}{l}\text { National } \\
\text { Banks }\end{array}$ & $\begin{array}{c}\text { Per cent } \\
\text { of } \\
\text { Total }\end{array}$ & $\begin{array}{l}\text { State } \\
\text { Banks }\end{array}$ & $\begin{array}{c}\text { Per cent } \\
\text { of } \\
\text { Total }\end{array}$ & $\begin{array}{c}\text { Total } \\
\text { Capital } \\
\text { Funds as a } \\
\text { Per cent of } \\
\text { Total Assets }\end{array}$ \\
\hline 1945 & $\$ 406,967$ & 188,580 & 46.2 & $\$ 218,487$ & 53.8 & 5.2 \\
\hline 1946 & 433,584 & 199,511 & 46.0 & 234,073 & 54.0 & 5.8 \\
\hline 1947 & 451,639 & 217,981 & 48.2 & 233,658 & 51.8 & 5.9 \\
\hline 1948 & 466,265 & 225,364 & 48.4 & 240,901 & 51.6 & 5.9 \\
\hline 1949 & 480,283 & 233,538 & 48.8 & 246,745 & 51.3 & 5.9 \\
\hline 1950 & 518,260 & 246,322 & 47.5 & 271,938 & 52.5 & 5.9 \\
\hline 1951 & 567,701 & 261,810 & 46.1 & 305,791 & 53.9 & 6.1 \\
\hline 1952 & 603,725 & 280,404 & 46.4 & 323,321 & 53.6 & 6.1 \\
\hline 1953 & 642,432 & 304,609 & 47.5 & 337,823 & 52.5 & 6.2 \\
\hline 1954 & 684,605 & 328,285 & 47.9 & 356,320 & 52.1 & 6.5 \\
\hline 1955 & 725,828 & 350,254 & 48.2 & 375,574 & 51.8 & 6.4 \\
\hline 1956 & 783,413 & 379,577 & 48.5 & 403,836 & 51.4 & 6.8 \\
\hline 1957 & 846,606 & 416,308 & 49.1 & 430,298 & 50.9 & 7.3 \\
\hline 1958 & 875,125 & 443,520 & 50.8 & 431,605 & 49.3 & 7.3 \\
\hline 1959 & 954,569 & 498,119 & 52.1 & 456,450 & 47.8 & 7.8 \\
\hline
\end{tabular}

Source: Annual Report of the Comptroller of the Currency, 1946-1960 and Annual Report of the Ohlo Division of Banks, 1946-1960. 
1. A11 Banks

In the 14-year period following World War II banks in onlo increased their total capital 133 per cent. The ratio of capital to total assets for all banks in Ohio increased from 5.2 per cent in 1945 to 7.8 per cent in 1959 . Increasing the capltal in relation to total bank assets is recognized by regulatory agencles and authorities in commercial banking as an 1mportant means of strengthening the structure of commercial banking.

Conversely, a high ratio of capital funds to assets places a bank in position to expand its $r$ isk asset holdings, elther directly or through acquisition of other banks through merger. Such banks can increase the ratio of profits to capital funds by more aggressive lending and investing policies and by expansion through acquisitions or in other ways, without having to welgh whether the capital position of the bank limits such expansion. 24

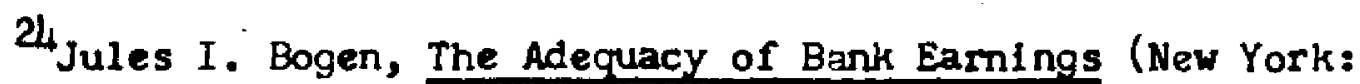
Graduate School of Business Adninistration of New York University, 1958), p. 30.

\section{National Banks}

National banks in Ohio increased their total capital by 165 per cent during the postwar period. In 1945 national banks controlled 1.6.2 per cent of the total bank capital in Ohio, and in 1959 the proportion held by national banks had risen to 52.1 per cent of the total.

\section{State Banks}

State banks managed to increase thelr total capital by 109 per cent during the subject perlod. In 1945 state banks accounted 
for 53.8 per cent of total bank capital in onlo; however, by 1959 this proportion had declined to 47.8 per cent.

$$
\text { G. Composition of Bank Capital in Ohio }
$$

Table 45 ( see Appendix) presents the major categories of bank capital in Ohio, and the proportion of total capltal each category represented curing the postwar period.

\section{Capital Stock}

All but a small fraction of the total outstanding stock of banks in Ohio is represented by common stock. In 1945 the banks in Ohio had outstanding $\$ 13,234,000$ in preferred stock, and in 1959 only $\$ 365,000$ remalned outstanding, all of which was accountable to state banks. 25

\section{Annual Report of the Comptroller of the Currency, 1946 and 1960.}

Although the value of outstanding stock of a 11 banks in Ohio was Increased by 93.4 per cent during the postwar period, the outm standing stock declined from 36.6 per cent of the total capital in 1945 to 30.2 per cent in 1959.

2. Notes and Debentures

During the postwar period the only outstanding notes and debentures of banks in Ohio were those of a small number of state banks. In 1945 the forementioned state banks had a total of $\$ 14,138,000$ In notes and debentures outstanding and in 1959 this total had been 
reduced to $\$ 100,000$. The issuance of notes and debentures by banks is looked upon unfavorably by bank management and regulatory agencies due to the structure of bank liabilities.

Because deposit liabilities resemble debt financing in some respects and because senior securities would have to be subordinated to the clalms of depositors if they are to function as capital funds, banks have generally linited their capitalization to capital stock. 26

\section{Bogen, Adequacy of Bank Earnings, p. 12.}

\section{Surplus}

In 1945 the surplus account represented 40.0 of total bank capital, but by 1956, 54.6 per cent of the total capital of all banks in Ohio was held in the surplus account. In 1959, the percentage had declined to 51.4 per cent.

The federal law requires that national banks create a surplus account equal to 20.0 per cent of total capital stock at the time of bank formation or conversion, and Ohio law requires the same of state chartered banks. 27

27 Federal Code Annotated, Title 12, Section 51, and Ohio Banking Law Annotated, 1103.10.

\section{Undivided Profits}

When retained earnings are placed in the undivided profits account management normally has more freedom actlon regarding what they may do with the account. Undivided profits may be used to pay 
future dividends, at a later time they may be placed in the surplus account, or they may be added to one of the reserve accounts for future contingencles.

The undivided profits account of all banks in ohio increased 236 per cent during the postwar period. As a proportion of the total capital of banks in ohio the undivided profits ranged from 12.2 per cen $t$ to 18.2 per cent of the total during the subject perlod. In 1959, 17.5 per cent of the total bank capital in Ohfo was carried in the undivided profits account.

\section{Reserves}

The reserves portion of the capital accounts of al 1 banks in ohio declined as a proportion of total capital throughout the postwar period. In 1945 reserves accounted for 7.8 per cent of total capital, and in 1959 the reserves accounted for less than 1.0 per cent of the total.

It should be noted, however, that the reserves portion of the capital accounts are only those reserves set aside for the retirement of stocks and bonds of banks in ohio. Valuation reserves set aside to meet possible losses on securities and loans are not included in the capital accounts. In 1959 the valuation reserves set aside to meet possible losses on loans of all banks in ohio amounted to $\$ 99,066,000$, or 10.3 per cent of total bank capital in ohio. 28

Annual Report of the Comptroller of the Currency, 1960. 
VII. Income and Operating Expense of Banks in Ohio

Table 14 presents the major components of operating income of banks in Chio during the postwar period, and the proportion of total operating Income provided by each component.

The statistics avallable on income and expense of all banks in Ohio are not segregated on the basis of national and state banks. The presentation of postwar income and operating expense, therefore, is 1 imf ted to total bank statistics rather than a division between national and state bank operations.

It should also be noted that the aggregate earnings of Federal Reserve member banks are larger than the aggregate earnings of nonmember banks. The earnings of member and nonmember banks in onio are not available; however, in 1959 the aggregate earnings of all member banks in the United States was five times as large as the aggregate earnings of all nonmember banks. At the same time member banks accounted for only 46 per cent of all banks in the United States. 29

\section{${ }^{29}$ Federa1 Reserve Bulletin, May, 1961, p. 616.}

\section{A. Composition of Total Operating Income}

The total operating income of all banks in onlo in 1959 exceeded the 1945 operating income by $\$ 339,794,000$. Expressed as a percentage the 1959 operating Income of all banks in Ohlo exceeded the 1945 operating income by 265 per cent. 
TABLE 14

COMPOSITION OF OPERATING INCOME OF ALL BANKS IN OHIO

1945-1959

(Thousands of Dollars)

\begin{tabular}{cccccccccccc}
\hline & $\begin{array}{c}\text { Total } \\
\text { Operating } \\
\text { Income }\end{array}$ & $\begin{array}{c}\text { Income } \\
\text { from } \\
\text { Loans }\end{array}$ & $\begin{array}{c}\text { Per } \\
\text { cent } \\
\text { of } \\
\text { Total }\end{array}$ & $\begin{array}{c}\text { Income } \\
\text { from In- } \\
\text { vestments }\end{array}$ & $\begin{array}{c}\text { Per } \\
\text { cent } \\
\text { of }\end{array}$ & $\begin{array}{c}\text { Income } \\
\text { from } \\
\text { Service } \\
\text { Charges }\end{array}$ & $\begin{array}{c}\text { Per } \\
\text { cent } \\
\text { of } \\
\text { Total }\end{array}$ & $\begin{array}{c}\text { Other } \\
\text { operating } \\
\text { Income }\end{array}$ & $\begin{array}{c}\text { Per } \\
\text { cent } \\
\text { of } \\
\text { Total }\end{array}$ & $\begin{array}{c}\text { Net } \\
\text { operating } \\
\text { Income }\end{array}$ & $\begin{array}{c}\text { Per } \\
\text { cent } \\
\text { of } \\
\text { Total }\end{array}$ \\
\hline 1945 & 128,375 & $\$ 38,457$ & 29.9 & $\$ 67,178$ & 52.3 & 10,257 & 8.0 & 12,484 & 10.2 & $\$ 29,839$ & 23.3 \\
1946 & 147,074 & 48,593 & 33.0 & 73,507 & 49.9 & 11,190 & 7.6 & 13,784 & 9.5 & 34,948 & 23.8 \\
1947 & 158,190 & 64,862 & 41.0 & 66,964 & 42.3 & 11,627 & 7.4 & 14,738 & 9.3 & 36,695 & 23.2 \\
1948 & 172,470 & 78,501 & 45.5 & 65,138 & 37.8 & 12,777 & 7.4 & 16,055 & 9.3 & 45,586 & 26.4 \\
1949 & 182,868 & 84,517 & 46.2 & 67,593 & 37.1 & 13,335 & 7.3 & 17,223 & 9.4 & 47,720 & 26.1 \\
1950 & 198,385 & 95,442 & 48.1 & 69,932 & 35.3 & 14,625 & 7.4 & 18,385 & 9.2 & 51,522 & 26.0 \\
1951 & 220,229 & 114,418 & 51.9 & 70,683 & 32.1 & 16,003 & 7.3 & 19,126 & 8.7 & 56,846 & 25.8 \\
1952 & 246,395 & 130,653 & 53.0 & 79,539 & 32.3 & 16,787 & 6.8 & 19,416 & 7.9 & 58,811 & 23.9 \\
1953 & 276,202 & 148,781 & 53.9 & 88,406 & 32.0 & 18,538 & 6.7 & 20,477 & 7.4 & 61,680 & 22.4
\end{tabular}


TABLE 14 (continued)

\begin{tabular}{|c|c|c|c|c|c|c|c|c|c|c|c|}
\hline Year & $\begin{array}{l}\text { Total } \\
\text { Operating } \\
\text { Income }\end{array}$ & $\begin{array}{l}\text { Income } \\
\text { from } \\
\text { Loans }\end{array}$ & $\begin{array}{l}\text { Per } \\
\text { cent } \\
\text { of } \\
\text { Total }\end{array}$ & $\begin{array}{c}\text { Income } \\
\text { from In- } \\
\text { vestments }\end{array}$ & $\begin{array}{l}\text { Per } \\
\text { cent } \\
\text { of } \\
\text { Total }\end{array}$ & $\begin{array}{c}\text { Income } \\
\text { from } \\
\text { Service } \\
\text { Charges }\end{array}$ & $\begin{array}{l}\text { Per } \\
\text { cent } \\
\text { of } \\
\text { Total }\end{array}$ & $\begin{array}{l}\text { Other } \\
\text { Operating } \\
\text { Income }\end{array}$ & $\begin{array}{l}\text { Per } \\
\text { cent } \\
\text { of } \\
\text { Total }\end{array}$ & $\begin{array}{l}\text { Net } \\
\text { Operating } \\
\text { Income }\end{array}$ & $\begin{array}{l}\text { Per } \\
\text { cent } \\
\text { of } \\
\text { Total }\end{array}$ \\
\hline 1954 & $\$ 290,443$ & $\$ 154,652$ & 53.3 & $\$ 91,944$ & 31.7 & $\$ 21,763$ & 7.5 & $\$ 22,083$ & 7.5 & $\pm 54,426$ & 18.6 \\
\hline 1955 & 321,684 & 174,767 & 54.3 & 98,247 & 30.5 & 24,558 & 7.6 & 24,112 & 7.6 & 81,051 & 25.1 \\
\hline 1956 & 367,451 & 210,409 & 57.3 & 104,330 & 28.4 & 27.158 & 7.4 & 25,554 & 6.9 & 95,553 & 26.1 \\
\hline 1957 & 405,722 & 238,940 & 58.9 & 109,229 & 26.9 & 30,066 & 7.4 & 27,486 & 6.8 & 92,533 & 22.9 \\
\hline 1958 & 420,497 & 245,801 & 58.5 & 114,077 & 27.1 & 31,934 & 7.8 & 28,686 & 6.6 & 73,129 & 17.3 \\
\hline 1959 & 466,069 & 276,937 & 59.4 & 123,869 & 26.6 & 34,937 & 7.5 & 30,327 & 6.5 & 117,359 & 25.1 \\
\hline
\end{tabular}

Source: How Does Your Bank Measure Up?, Ohio Bankers Associatl on, 1946-1960. 
1. Income from Loans

The Income generated by bank loans in 1959 exceeded the 1945 loan income by $\$ 248,480,000$. The income from bank loans rose from 20.9 per cent of total operating income in 1945 to 59.4 per cent in 1959. A partial explanation of the rapid increase in the income from loans is the increase in the rate of return on loans during the period. Table 15 presents the average rate of income on loans during the postwar period for all banks in Ohio. During the subject period the average income from loans increased from 2.98 per cent to 5.00 per cent.

2. Income from Investments

Income resulting from investments in securities by all banks in Ohio increased by 85.0 per cent during the period 1945 to 1959. As a proportion of total operating income, however, investment income declined from 52.3 per cent to 26.6 per cent during the period.

Table 15 reveals that the average rate of return on investments of 211 banks in Chio Increased from 1.36 per cent in 1945 to 2.76 in 1959. The differential in the average rate of return between loans and investments provides a partial explanation of the wide difference in the amount of income recelved from the two sources. In 1945 the total amount of income recelved from bank investments in ohio exceeded that recelved from loans by 76.3 per cent, but in 1959 the amount of income recelved on bank loans in Ohio exceeded the amount of income from investments by 58.9 per cent. 
TABLE 15

RATE OF INCOME ON TOTAL LOANS AND INVESTMENTS

OF ALL BANKS IN OHIO

1945-1959

(Thousands of Dollars)

\begin{tabular}{lccc}
\hline Year & $\begin{array}{c}\text { Rate of Income } \\
\text { on Loans } \\
\text { (Per cent) }\end{array}$ & $\begin{array}{c}\text { Rate of Income } \\
\text { on Investments } \\
\text { (Per cent) }\end{array}$ & $\begin{array}{c}\text { Rate of Income on } \\
\text { Loans and Invest- } \\
\text { ments Combined }\end{array}$ \\
\hline 1945 & 2.98 & 1.36 & 1.69 \\
1946 & 3.10 & 1.74 & 2.11 \\
1947 & 3.47 & 1.67 & 2.24 \\
1948 & 3.96 & 1.61 & 2.38 \\
1949 & 4.14 & 1.57 & 2.39 \\
1950 & 3.81 & 1.67 & 2.47 \\
1951 & 4.13 & 1.65 & 2.61 \\
1952 & 4.20 & 1.76 & 2.75 \\
1953 & 4.34 & 1.93 & 2.96 \\
1954 & 4.35 & 1.91 & 2.94 \\
1955 & 4.20 & 2.13 & 3.11 \\
1956 & 4.51 & 2.41 & 3.50 \\
1957 & 4.87 & 2.51 & 3.76 \\
1958 & 4.09 & 2.46 & 3.72 \\
1959 & 5.00 & 2.76 & 4.07 \\
\hline & & & \\
\hline
\end{tabular}

Source: How Does Your Bank Measure Up?, Ohi o Bankers Association, 1946-1960. 


\section{Income from Service Charges}

The amount of income received from service charges by banks in Oh10 in 1959 exceeded the amount received in 1945 by $\$ 24,680,000$. As a percentage of total operating income, however, service charges declined from 8.0 per cent in 1945 to 7.5 per cent in 1959.

4. Net Operating Income

The net operating income of all banks in Ohio in 1959 exceeded the 1945 flgure by 293 per cent. As a percentage of total operating income, however, net operating income remained rather stable throughout the postwar period. During the 14 -year period net operating income ranged from 17.3 per cent to 26.1 per cent of total operating income, and in only two of the 14 years net operating income declined below 20.0 per cent of total operating income.

\section{B. Composition of Total Operating Expense}

Table 16 presents the major categories of total operating expense of all banks in Ohio from 1945 to 1959, and the proportion of total operating expense provided by each category.

The total operating expenses of banks in chio in 1959 exceeded the 1945 total by $\$ 250,174,000$.

\section{Interest Paid on Deposits}

As a proportion of total operating expense, the interest paid on deposits was stable unti1 1957. From 1945 to 1956 the interest pald on deposits as a percentage of total operating expense ranged between 15.4 per cent and 19.9 per cent. The increase in the mount 
TABLE 16

COMPOSITION OF TOTAL OPERATIN, EXPENSE

OF ALL BANKS IN OHIO

$1945-1959$

(Thousands of Dollars)

\begin{tabular}{cccccccccc}
\hline Year & $\begin{array}{c}\text { Total } \\
\text { Operating } \\
\text { Expense }\end{array}$ & $\begin{array}{c}\text { Interest } \\
\text { Paid on } \\
\text { Deposi ts }\end{array}$ & $\begin{array}{c}\text { Per cent } \\
\text { of } \\
\text { Total }\end{array}$ & Taxes & $\begin{array}{c}\text { Per cent } \\
\text { of } \\
\text { Total }\end{array}$ & Salaries & $\begin{array}{c}\text { Per cent } \\
\text { of } \\
\text { Total }\end{array}$ & $\begin{array}{c}\text { Other } \\
\text { Operating } \\
\text { Expenses }\end{array}$ & $\begin{array}{c}\text { Per cent } \\
\text { of } \\
\text { Tota1 }\end{array}$ \\
\hline 1945 & $\$ 98,536$ & $\$ 19,168$ & 19.1 & 22,806 & 23.2 & $\$ 31,680$ & 32.3 & $\$ 24,703$ & 25.4 \\
1946 & 112,126 & 21,895 & 19.6 & 26,138 & 23.2 & 37,056 & 33.0 & 27,037 & 24.2 \\
1947 & 121,459 & 23,696 & 19.8 & 26,231 & 21.4 & 41,546 & 34.7 & 32,021 & 24.1 \\
1948 & 126,883 & 24,487 & 18.8 & 24,326 & 18.9 & 45,887 & 37.8 & 32,183 & 24.5 \\
1949 & 135,149 & 25,476 & 18.5 & 26,568 & 20.0 & 49,206 & 36.2 & 33,896 & 25.3 \\
1950 & 146,863 & 25,795 & 17.6 & 32,472 & 21.7 & 53,035 & 36.0 & 35,561 & 24.7 \\
1951 & 163,382 & 26,588 & 16.5 & 39,604 & 22.0 & 59,637 & 36.7 & 37,553 & 24.8 \\
1952 & 187,584 & 29,411 & 15.4 & 48,306 & 25.7 & 67,038 & 36.0 & 42,798 & 22.9 \\
1953 & 214,522 & 37,930 & 17.6 & 53,859 & 24.1 & 74,730 & 34.8 & 48,002 & 23.5 \\
1954 & 236,017 & 44,626 & 19.9 & 60,567 & 25.8 & 79,959 & 33.9 & 50,864 & 20.4
\end{tabular}


TABLE 16 (continued)

\begin{tabular}{cccccccccc}
\hline Year & $\begin{array}{c}\text { Total } \\
\text { Operating } \\
\text { Expense }\end{array}$ & $\begin{array}{c}\text { Interest } \\
\text { Paid on } \\
\text { Deposits }\end{array}$ & $\begin{array}{c}\text { Per cent } \\
\text { of } \\
\text { Total }\end{array}$ & Taxes & $\begin{array}{c}\text { Per cent } \\
\text { of } \\
\text { Total }\end{array}$ & Salaries & $\begin{array}{c}\text { Per cent } \\
\text { of } \\
\text { Total }\end{array}$ & $\begin{array}{c}\text { Operating } \\
\text { Total }\end{array}$ \\
\hline 1955 & $\$ 240,633$ & $\$ 48,384$ & 19.9 & $\$ 50,363$ & 20.7 & $\$ 85,868$ & 35.7 & $\$ 56,018$ & 23.7 \\
1956 & 271,897 & 53,615 & 19.8 & 59,053 & 21.6 & 95,604 & 35.2 & 63,624 & 23.4 \\
1957 & 334,389 & 67,546 & 20.3 & 72,900 & 21.8 & 104,273 & 31.1 & 69,470 & 24.8 \\
1958 & 347,369 & 78,580 & 22.7 & 82,325 & 23.6 & 109,882 & 31.1 & 73,316 & 22.6 \\
1959 & 348,710 & 92,484 & 26.3 & 62,496 & 17.7 & 115,123 & 32.9 & 78,608 & 23.1 \\
\hline
\end{tabular}

Includes Federal Corporate Income $\mathrm{Tax}$ as well as all other taxes.

Source: How Does Your Bank Measure Up?, Ohlo Bankers Association, 1946-1960. 
of Interest paid on time deposits in 1957 caused the percentage to increase, and in 1959 interest paid on deposits represented 26.3 per cent of total operating expenses of all banks in Ohio.

\section{Taxes}

The total taxes paid by a 11 banks in Ohio in 1959 exceeded the 1945 tax payment by 179 per cent. 30 As a proportion of total operating

30 UntI 12953 the statistics available on operating expenses of banks in Chio included Federal Corporate Income tax payments in the tax portion of total operating expenses. There was no indication of what part of the total tax expense was represented by income tax payments. In order to assure uniformity in the statistics the income tax payments total which was available after 1953 have been added to the other taxes paid by banks in Ohio, and the total has been treated as an operating expense throughout the entire postwar perlod.

expenses, taxes pald by banks in Ohio have ranged between 17.7 per cent and 25.8 per cent during the postwar period.

\section{Salaries}

The total salaries paid by all banks in Ohio in 1959 exceeded the total salaries paid in 1945 by $\$ 83,443,000$. As a proportion of total operating expenses, the salaries paid by banks in Ohio ranged from 31.1 per cent to 37.8 per cent of the total. In 1945 salaries accounted for 32.3 per cent of the total operating expenses, and in 1959 salaries represented 32.9 per cent of the total.

\section{Total Net Income and Dividends}

The net income of all banks in Ohio in 1959 was 63.8 per cent more than the net income in 1945. Table 17 presents the amount of 
TABLE 17

TOTAL NET INCOMI OF ALL BANKS IN OHIO 1945-1959

(Thousands of Dollars)

\begin{tabular}{ccc}
\hline Year & $\begin{array}{c}\text { Total } \\
\text { Net Income }\end{array}$ & $\begin{array}{c}\text { Total Income } \\
\text { as a Per cent } \\
\text { of Total } \\
\text { Capital }\end{array}$ \\
\hline 1945 & $\$ 46,844$ & 12.2 \\
1946 & 48,496 & 11.6 \\
1947 & 37,137 & 8.5 \\
1948 & 35,707 & 7.8 \\
1949 & 44,156 & 9.1 \\
1950 & 49,158 & 9.4 \\
1951 & 49,159 & 8.7 \\
1952 & 47,348 & 7.8 \\
1953 & 47,779 & 7.4 \\
1954 & 57,537 & 8.5 \\
1955 & 57,231 & 7.9 \\
1956 & 62,886 & 8.0 \\
1957 & 71,665 & 8.5 \\
1958 & 77,303 & 8.9 \\
1959 & 77,061 & 8.0 \\
\hline
\end{tabular}

Source: How Does Your Bank

Measure Up?, Ohio Bankers Association, 19461960. 
net income of all banks in ohio and the ratio of net income to total capital during the subject period.

The years 1945 and 1946 were the years in which the total net income represented the largest percentage of total capital funds. From 1947 to 1959 the net income of banks in Ohio ranged between 9.4 per cent and 7.5 per cent of total capital funds.

Table 46 (see Appendix) presents the amount of total cash dividends pald by banks in Ohio during the subject period, and the percentage of total net income paid out in cash dividends. It is apparent from an examination of Table 46 that the total amount paid in cash dividends by banks in Ohto increased in every year of the postwar period. The pay out ratio (percentage of total net income pald out in cash dividends) did not demonstrate the same stability as the mount of dividends. The range of the pay out ratio during the period 1945 to 1959 was 19.1 to 35.4 per cent. As a result of the fluctuations in the pay out ratio, it appears that no pattern exists in total dividend payments other than the fact that they increased in total amount each year of the postwar period.

\section{Summary}

In the 14 years following the end of world War II the structure of banking in Ohio changed in the number and affiliations of banks, the amount and composition of assets, deposits, and capital, and the income and expense pattern of banks. 
As a result of the increase in the number of branch banks in Ohio during the postwar period the number of banking offices increased while the number of banks declined. Due to the smaller number of basks in operation and an increasing population the average number of persons per bank in Ohio Increased, but the increase in branch offices provided approximately the same ratio of population per banking office as existed at the beglnning of the postwar perlod.

The national banks in ohio became more prominent in terms of the number of banks and banking offices. National banks, unltke state banks in Ohio, had a small decline in the number of banks in operation. At the same time the national banks increased branch bank operations at a swlfter pace than the state banks in Ohio. The result was that during the postwar perlod national banks in onlo increased the proportion of total banks and banking offices under their control. State banks, however, continued to account for the largest number of banks and banking of fices in Ohio throughout the postwar period.

The decline in the total number of banks in Ohlo more than offset the formation of new banks, but a combined total of 33 new national and state bank charters were granted by regulatory authorities. The majority of new banks were formed under state charters and were located in small and medium-sized Ohio communities.

Ohlo banks were geographically diversiffed throughout the period in splte of the reduction in the number of banks. Counties with heavy reductions in the number of banks were those with the 
largest number of banks in operation at the beginning of the postwar period. The majority of the Ohio counties were served by both national and state banks throughout the postwar period.

Membership in the Federal Deposit Insurance Corporation was maintained by all but a fraction of the banks in Ohlo during the entire period, and in 1959 only one bank in onlo remained as a noninsured bank. It should be noted that the noninsured bank remained as the only bank in Ohlo without some form of federal bank regulation and jurisdiction. Membership in the Federal Reserve System was maintained by approximately 60.0 per cent of all banks in Ohio throughout the 14-year period.

The resources of the banks in onio changed both in quantity and composition from 1945 to 1959 . The total bank assets in Ohio increased 55.5 per cent during this period. The national banks in ohio had the largest increase in assets, and as a result the total assets of national banks exceeded the total assets of state banks in Ohio during the postwar period. At the end of the subject period the average asset size of national banks in Ohio was 37.1 per cent larger than the average assets of all banks in the state. State banks, on the other hand, had average assets that were 22.9 per cent below the all bank average in ohio in 1959.

The proportion of total bank assets in Ohio held in the form of loans and discounts expanded during the postwar period, while the proportion of total assets represented by United States government 
obligations declined by nearly the same proportion. Loans for consumer instalment credit and real estate loans increased as a proportion of total loans while commercial and industrial loans remained stable, and loans for the purchase of securities and loans to dealers and brokers declined substantially as a proportion of total loans.

The total deposits of banks in Ohio expanded by 49.6 per cent during the postwar period. The most significant increase in deposits took place in the time deposits. During the subject period the time deposits of all banks in Ohfo increased 73.8 per cent while demand deposits increased 37.6 per cent.

The national banks in Ohio also gained control of the majority of total bank deposits during the postwar period. The state banks in Ohio falled to Increase total deposits at a rate equal to that of the national banks, and as a result the state banks relinquished the dominant position they held in total deposits at the beginning of the subject period. The state banks continued to hold the greatest portion of total bank time deposits in Ohio, but the national banks had narrowed the difference substantially by 1959.

The total capital of banks in Ohio increased by 133 per cent between 1945 and 1959. The most significant increase took place in the surplus accounts. Natfonal banks also surpassed state banks in the expansion of total capital during the subject perlod. The national banks in Ohio Increased total capltal 165 per cent while the state banks reglstered an increase of 109 per cent. 
The operating income of all banks in ohio increased in each year of the $W_{1}$-year period. The income resulting from bank loans became a larger proportion of total operating income during the perlod while the income earned from investments declined. Income resulting from service charges continued to provide approximately the same proportion of operating income throughout the postwar period.

The total operating expenses of banks in ohio increased rapidly during the postwar period, but the increase was less than that experienced in operating income. All of the major components of operating expense remained rather stable as a percentage of the total with the exception of interest paid on deposits which increased rather sharply after 1956.

The net income of banks in ohio increased in the postwar period, and as a result the total dividends paid to stockholders in Ohio banks increased in each year of the 14 -year period. 
CHAPTER III

BANKING CONCENTRATION AND COMPETITION IN OHIO

The purpose of this chapter is to measure and analyze the concentration of total bank resources exercised by the large metropolitan banks in onfo during the postwar period, and to compare the extent of bark concentration in Ohlo with the rest of the United States. In additi on, Chapter III contains an examination of the amount and methods of competition in banking in Ohio during the subject period.

I. Concentration Exercised by the Large Metropolitan Banks in Ohio During the Postwar Period

Tables 47 and 48 (see Appendix) present the total assets, deposits, and capltal of the 20 largest banks in ohio in 1945 and 1959. Table 18 presents the proportlon of total bank assets, deposits, and capital in Ohlo controlled by the 20 largest banks in 1945 and 1959. The basis of selection of the largest banks was the size of total assets in 1945 and 1959.

A. The Largest Bank in Ohio

The Cleveland Trust Company was the largest bank in Ohto in 1945 and remained in that position throughout the postwar period. In 1945 the total assets of the Cleveland Trust Company exceeded the total assets of the second largest bank in Ohio by 123 per cent, 
but in 1959 the dffference in the total assets of the two banks had been reduced to 76 per cent. Throughout the postwar period the Cleveland Trust Company was the only bank in Ohto with total assets of more than $\$ 1$ billion.

In 1945 the Cleveland Trust Company controlled 14.20 per cent of the total bank assets in Ohio and in 1959 it held 11.96 per cent of the total. At the beginning of the postwar period, 18.16 per cent of the total bank loans and discounts in Ohio were held by the Cleveland Trust Company, but in 1959 this percentage had been reduced to 15.21 per cent.

During the entire 14-year period the only category of assets In which the Cleveland Irust Company increased its control of the total was the "other securities" category. This category includes state and local goverment obligations, stock in the Federal Reserve Bank of Cleveland, and securities of private enterprises. In 1945, the Cleveland Trust Company accounted for 5.30 per cent of all "other securities" held by banks in Ohio, and in 1959 it had increased the proportion to 10.39 per cent of the total.

In 1945 the Cleveland Trust Company held 14.25 per cent of the total bank deposits in Ohio, but in 1959 the proportion of the total held by this bank had declined to 12.03 per cent.

The proportion of total bank capital in Ohio under the control of the Cleveland Trust Company remained stable during the postwar perlod. In 1945 this bank accounted for 11.91 per cent of total bank capital in Ohio, and in 1959 the percentage was 11.09 per cent. 
B. The Five Largest Banks in Ohio

In 1945 the three largest banks in Ohio were located in Cleveland, the fourth largest in Toledo, and the fifth in Cinclnnati. In 1959 the three largest banks in Ohio consisted of the same banks in the same order. The fourth and fifth largest banks, however, were located in Cincinnati and Columbus in 1959. In 1945 the difference in the total assets of the largest bank and the fifth largest bank in Chio totaled $\$ 829,880,000$, but by 1959 the difference in assets had been extended to $\$ 1,007,345,000$.

In 1945 the five largest banks in Ohio accounted for 33.12 per cent of the total bank assets, and in 1959 they held 31.26 of the total bank assets in the state.

The decline in the total deposits under the control of the five largest banks was nearly equal to the decline in the proportion of total assets held by these same banks. In 1945 the five banks accounted for 33.17 per cent of the total bank deposits in Onio, and in 1959 the percentage had declined to 31.31 per cent.

The proportion of total bank capltal in ohlo accounted for by the flve major banks was 30.15 per cent in 1959, as compared to 29.98 per cent in 1945.

C. The Ten Largest Bants in Onio

In 1945 the ten largest banks in Ohio were composed of four banks in Cleveland, three banks in Cincinnati, and the three remaining banks were located in Columbus, Dayton, and Toledo. In 1959 five of 
the ten largest banks in Ohio were located in Cleveland, and these five banks accounted for 65.52 per cent of the total assets of the ten largest banks in ohio and 33.70 per cent of the total bank assets in Ohio. The five remaining banks were located in Cincinnati, Columbus, and Toledo in 1959.

It is also notable that in 1945 and 1959 the ten largest banks in Ohlo were equally divided between national and state chartered banks. The five 1argest banks in 1945 were composed of two national banks and three state banks. In 1959, however, four of the five largest banks were national banks, and only The Cleveland Trust Company remained as the state chartered bank among the five major banks in the state.

The proportion of total assets under the control of the ten largest banks in Ohio experienced a smal1 dec1lne in the 14 years following the postwar period. In 1945 the 10 leading banks accounted for 46.29 per cent of the total bank assets in Ohio, and in 1959 this proportion had been reduced to 45.45 per cent. The share of total deposits accounted for by the ten banks also declined from 46.47 per cent in 1945 to 45.09 per cent in 1959.

The proportion of total capital held by the ten largest banks increased from 42.20 per cent in 1945 to 45.76 per cent in 1959. 
TABLE 18

PERCENTAGE OF TOTAL BANK ASSETS, DEPOSITS, AND CAPITAL IN OHIO CONTROLLD BY THE 20 LARGEST BANKS IN OHIO IN 1945 AND 1959

\begin{tabular}{|c|c|c|c|c|c|c|c|}
\hline 1945 & $\begin{array}{c}\text { Per cent } \\
\text { of } \\
\text { Total Assets }\end{array}$ & $\begin{array}{l}\text { Per cent } \\
\text { of Cash and } \\
\text { in Banks }\end{array}$ & $\begin{array}{l}\text { Per cent of } \\
\text { U.S. Govt. } \\
\text { Securities }\end{array}$ & $\begin{array}{l}\text { Per cent } \\
\text { of other } \\
\text { Securities }\end{array}$ & $\begin{array}{l}\text { Per cent } \\
\text { of Loans and } \\
\text { Discounts }\end{array}$ & $\begin{array}{l}\text { Pur cent } \\
\text { of } \\
\text { Total } \\
\text { Deposits }\end{array}$ & $\begin{array}{l}\text { Per cent } \\
\text { of } \\
\text { Total } \\
\text { Capital }\end{array}$ \\
\hline Largest Banik & 14.20 & 11.01 & 14.98 & $5 \cdot 30$ & 18.16 & 14.25 & 11.91 \\
\hline 5 Largest Banks & 33.12 & 29.83 & 33.87 & 14.13 & 40.08 & 33.17 & 29.28 \\
\hline 20 Largest Banks & 58.87 & 57.23 & 58.39 & 33.32 & 61.65 & 59.15 & 53.59 \\
\hline \multicolumn{8}{|l|}{1959} \\
\hline 20 Largest Banks & 58.78 & 65.57 & 54.68 & 51.27 & 59.92 & 58.71 & 57.80 \\
\hline
\end{tabular}

Source: Tables 47 and 48 . 
D. The 20 Largest Banks in Ohio

In 1945 and 1959 the 20 largest banks in Ohio were located in the seven largest metropolitan centers in onlo. The order and composition of representation changed, however, during the postwar period.

The proportion of total bank assets in Ohio controlled by the 20 leading banks in 1945 remained nearly the same in 1959. In 1945 , 58.87 per cent of the total bank assets in the state were held by the 20 1argest banks, as compared to 58.78 per cent in 1959 . The proportion of total bank deposits in Ohio accounted for by the 20 largest banks also remained substantially unchanged from 1945 to 1959 . The total bank capltal in Ohio held by the 20 largest banks increased from 53.39 per cent in 1945 to 57.80 per cent in 1959.

The 20 largest banks in Ohio were also evenly divided between national and state chartered banks in 1945 and 1959.

\section{Geographic Concentration}

Tables 47 and 48 (see Appendix) show the location of the 20 largest banks in Ohio in 1945 and 1959, and from these tables it is evident that the largest banks in Ohio are located in the seven major metropolitan areas in ohio.

Tables 19 and 20 present the total deposits, demand deposits, and time deposits of individuals, partnerships, and corporations located 
TABLE 19

DEPOSITS OF INDIVIDUALS, PARTNERSHIPS, AND CORPORATIONS

IN THE METROPOLITAN COUNTIES OF OHIO

DECETBER 31,1947

\begin{tabular}{|c|c|c|c|c|c|c|c|}
\hline County & $\begin{array}{c}\text { Total } \\
\text { Deposits }\end{array}$ & $\begin{array}{l}\text { Per cent of } \\
\text { Ohi o Total }\end{array}$ & $\begin{array}{c}\text { Demand } \\
\text { Deposits }\end{array}$ & $\begin{array}{l}\text { Per cent of } \\
\text { Ohio Total } \\
\end{array}$ & & $\begin{array}{l}\text { Time } \\
\text { Deposits }\end{array}$ & $\begin{array}{l}\text { Per cent of } \\
\text { Ohio Total }\end{array}$ \\
\hline Curyahoga & $\$ 1,970,842$ & 31.14 & $\$ 1,071,208$ & 29.39 & $\$$ & 899,634 & 33.17 \\
\hline Frankl1n & 341,424 & 5.38 & 247,064 & 6.78 & & 94,360 & 3.49 \\
\hline Hamilton & 788,130 & 12.45 & 556,689 & 12.54 & & 231,441 & 8.60 \\
\hline Lucas & 325,075 & 5.13 & 215,602 & 8.64 & & 109,473 & 4.05 \\
\hline Mahoning & 158,685 & 2.51 & 89,167 & 2.44 & & 69,518 & 2.60 \\
\hline Montgomery & 228,666 & 3.61 & 167,029 & 4.58 & & 61,637 & 2.30 \\
\hline Stark & 173,835 & 2.74 & 93,365 & 2.58 & & 80,470 & 2.97 \\
\hline Sumit & 261,531 & 4.13 & 141,892 & 3.84 & & 119,639 & 4.46 \\
\hline Total & $14,248,188$ & 67.09 & $\$ 2,582,016$ & 70.79 & $\$$ & $1,666,172$ & 61.64 \\
\hline $\begin{array}{l}\text { Ohio } \\
\text { Total }\end{array}$ & $6,329,003$ & 100.00 & $3,642,687$ & 100.00 & & $2,686,316$ & 100.00 \\
\hline
\end{tabular}

Source: Board of Governors of the Federal Reserve System, Distribution of Bank Deposits by Counties, July, 1948 . 
TABLE 20

DEPOSITS OF INDIVIDUALS, PARTNERSHIPS, AND CORPORATIONS

IN THE METROPOLITAN COUNTIES OF OHIO

DECENBER 31, 1959

(Thousands of Dollars)

\begin{tabular}{|c|c|c|c|c|c|c|}
\hline County & $\begin{array}{c}\text { Total } \\
\text { Deposits }\end{array}$ & $\begin{array}{l}\text { Per cent of } \\
\text { Ohio Total }\end{array}$ & $\begin{array}{l}\text { Demand } \\
\text { Deposits }\end{array}$ & $\begin{array}{l}\text { Per cent of } \\
\text { Ohio Total }\end{array}$ & $\begin{array}{l}\text { Time } \\
\text { Deposits }\end{array}$ & $\begin{array}{l}\text { Per cent of } \\
\text { Ohio Total }\end{array}$ \\
\hline Ouyahoga & $\$ 2,784,958$ & 29.96 & $\$ 1,481,357$ & 26.71 & $\$ 1,303,601$ & 31.58 \\
\hline Frank11n & 577,959 & 6.21 & 417,620 & 7.89 & 160,339 & 3.87 \\
\hline Hami 1ton & $1,007,934$ & 10.84 & 745,678 & 14.23 & 262,256 & 6.35 \\
\hline Lucas & 506,842 & 5.34 & 310,886 & 6.01 & 195,956 & 4.75 \\
\hline Mahon Ing & 249,576 & 2.69 & 137,460 & 2.65 & 112,116 & 2.71 \\
\hline Montgomery & 364,134 & 3.91 & 261,862 & 5.06 & 102,272 & 2.48 \\
\hline stark & 269,392 & 2.90 & 140,871 & 2.72 & 128,521 & 3.12 \\
\hline Sumit & 457,778 & 4.92 & 247,313 & 4.77 & 210,465 & 5.09 \\
\hline Total & $\$ 6,218,573$ & 66.77 & $\$ 3,743,047$ & 70.04 & $\$ 2,457,526$ & 59.95 \\
\hline Ohlo Total & $9,293,993$ & 100.00 & $5,168,651$ & 100.00 & $4,125,342$ & 100.00 \\
\hline
\end{tabular}

Source: Board of Governors of the Federal Reserve System, Distribution of Bank Deposits by Counties and Standard Metropolitan Areas, June, 1960. 
in the efght metropolitan counties of Ohio in 1947 and $19599^{1}$ Any

$1_{\text {The Federal Reserve System did not undertake surveys of total }}$ bank deposits by counties unt 11 1947; as a result statistics on benk deposits in the 88 ohio counties were not aval lable until 1947.

county which, at the time of the 1950 census, contained a city of 100,000 Inhabitants or more was classified as a metropolitan county. At that time there were eight metropolitan counties in Ohio: Cuyahoga, Franklin, Hamilton, Lucas, Mahoning, Montgomery, Stark, and Sumft. 2

'Division of Economic Research, Economic Data Series: Popula tion Series (Columbus, Ohio: Ohio Departinent of Industrial and Economic Development, 1960), p. 14 .

The population totals for the elght metrcpolitan counties in Onlo are not avallable for 1945, but actual figures are available for 1950 and estimated figures for $1959 .{ }^{3}$ In 1950 the elght metropolitan

3ibid., P. 1-R.

counties in ohio contained 54.89 per cent of the total population of Ohio, and in 1959, 55.10 per cent of Ohio's total population resided in the efght metropolitan counties.

In 1950 the metropolitan counties in Ohio provided 63.75 per cent of the total personal income in Ohio, as compared to 61.13 per cent in 1959.4

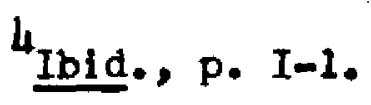


In $1947,67.09$ per cent of the total bank deposits in Onio were located in the banks in the eight metropolitan countles. In 1959 all the banks in the metropolitan counties accounted for 66.77 per cent of the total bank deposits in Ohio.

In 1947 the total demand deposits of a11 banks in the eight metropolitan counties accounted for 70.79 per cent of the total demand deposits in Ohio, and the time deposits in the subject banks represented 61.64 per cent of total time ceposits in Ohio. The demand deposits in the Ohio metropolitan counties represented 70.04 of the Ohio total in 1959, and at the same time 59.95 per cent of the total time deposits in the state were located in the banks in the metropolitan counties.

Cuyahoga County had the largest total bank deposits of the 88 ohio counties in 1947 and 1959. In 1947 the banks located in Cuyahoga County accounted for 31.14 per cent of the total bank deposits in Ohio, as compared to 29.96 per cent in 1959.

The banks in Hamilton County also held a smaller proportion of total bank deposits in Ohio in 1959 than in 1947. In 1959, however, the remaining six metropolitan counties in Ohio each contained a larger proportion of Ohio's total bank deposits than they had in 1947. Franklin County had the largest percentage increase. In 1947 Frank1 in County accounted for 5.38 per cent of the Ohio total as compared to 6.21 in 1959. 
IIT. Comparison of Bank Concentration in ohio and the United States

Table 49 and 50 (see Appendix) present the assets, deposits, and capital of all insured commercial banks in the United States on June 10, 1959, and the percentage of the total resources controlled by each deposit group. Tables 51 and 52 (see Appendix) present the same information for all insured commercial banks in ohio on the same date.

In 1959 there were 19 insured commercial banks in the United States with total deposits in excess of $\$ 1$ billion. These 19 banks represented . 14 per cent of the total insured banks in the Unlted States, and they controlled 27.33 per cent of the total insured bank assets. During the same period the state of Ohio had one bank with deposits in excess of $\$ 1$ billion which represented .16 per cent of the total number of Insured banis in Ohio, but it controlled only 12.50 per cent of the insured bank assets in the state.

In 1959 a total of 258 insured banks in the United States had total deposits exceeding $\$ 100$ million. These banks accounted for 1.85 per cent of all the insured banks and controlled 58.02 per cent of the assets in the United States. There were 16 banks in Ohio, on June 10,1959 , with deposits totaling $\$ 100$ million or more, and these banks represented 2.69 per cent of all of the insured banks in the state and held 54.91 per cent of the total assets.

The largest number of insured banks in both the United States and Ohio had total deposits ranging from $\$ 2$ to $\$ 5 \mathrm{million}$. The number 
of insured commercial banks in the United States in this deposit category represented 33.17 per cent of the total, and in chio this category accounted for 33.00 per cent of the insured banks in the state. The total deposits of these banks accounted for 6.72 per cent of the total insured bank deposits in the United States, a nd 6.10 per cent of the insured deposits in Ohio.

The insured banks in the United States with deposits of less than $\$ 10$ million totaled 9,687 and represented 81.58 per cent of all insured banks in the nation. The insured banks in Ohlo with total deposits under $\$ 10 \mathrm{mi} 111$ on numbered 455 and accounted for 76.21 per cent of all insured banks in Ohio. This deposit category provided 16.17 per cent of the total bank assets in Ohio and 16.65 per cent of the total bank assets in the United States.

It is apparent from this study that in June of 1959 the trend toward concentration of bank resources was less pronounced in Ohio than in the balance of the country.

\section{The Economies of Large Scale Banking in Chio}

As was previously stated the majority of the banking resources In Ohto during the postwar period have been controlled by the 20 largest banks in the state. One of the advantages which the se banks possess results from the $\infty$ st economies galned from operating on a larger scale. Table 21 presents the operating ratios for all Federal Reserve member banks in Ohio in 1959 grouped by deposit size. 
TABLE 21

OPERATING RATIOS FOR ALL FEDERAL RESERVE MEMEER BANKS IN OHIO GROUPED BY ASSET SIZE

1959

\begin{tabular}{|c|c|c|c|c|c|c|}
\hline $\begin{array}{l}\text { Deposit Size in } \\
\text { Millions of } \\
\text { Dollars }\end{array}$ & $\begin{array}{l}\text { Number } \\
\text { of } \\
\text { Banks }\end{array}$ & $\begin{array}{l}\text { Total Expenses } \\
\text { as a Per cent of } \\
\text { Total Earnings }\end{array}$ & $\begin{array}{l}\text { Return on } \\
\text { Total } \\
\text { Loans }\end{array}$ & $\begin{array}{l}\text { Return on } \\
\text { U.S. Govt. } \\
\text { Secur'ti es }\end{array}$ & $\begin{array}{l}\text { Net Profits } \\
\text { as a Per cent } \\
\text { of Total Assets }\end{array}$ & $\begin{array}{l}\text { Net Profits as } \\
\text { a Per cent of Total } \\
\text { Capltal Accounts }\end{array}$ \\
\hline Up to 1 & 24 & 77.2 & 5.83 & 2.77 & .38 & 2.9 \\
\hline 1 to 2 & 39 & 74.2 & 5.89 & 2.78 & .70 & 7.0 \\
\hline 2 to 5 & 118 & 71.2 & 5.79 & 2.83 & .67 & 7.0 \\
\hline 5 to 10 & 91 & 69.8 & 5.90 & 2.83 & .57 & 6.9 \\
\hline 10 to 25 & 61 & 71.6 & 5.78 & 2.79 & .55 & 6.9 \\
\hline 25 to 50 & 20 & 72.0 & 5.98 & 2.76 & .40 & 5.9 \\
\hline 50 to 100 & 10 & 66.8 & 5.68 & 2.72 & .66 & 8.7 \\
\hline 100 and over & 16 & 62.9 & 5.52 & 2.83 & .69 & 9.1 \\
\hline $\begin{array}{l}\text { Total Ohio Member } \\
\text { Banks }\end{array}$ & 369 & 71.0 & 5.82 & 2.81 & .60 & 6.9 \\
\hline
\end{tabular}


TABLE 21 (continued)

\begin{tabular}{lccc}
\hline $\begin{array}{l}\text { Deposit Size } \\
\text { in Millions } \\
\text { of Doliars }\end{array}$ & $\begin{array}{c}\text { Capital Accounts } \\
\text { as a Per cent of } \\
\text { Total Assets }\end{array}$ & $\begin{array}{c}\text { Capital Accounts } \\
\text { as a Per cent of } \\
\text { Risk Assets }\end{array}$ & $\begin{array}{c}\text { Time Deposits } \\
\text { as a Per cent of } \\
\text { Total Deposits }\end{array}$ \\
\hline Up to 1 & 12.9 & 26.6 & 47.6 \\
1 to 2 & 10.4 & 21.6 & 51.1 \\
2 to 5 & 9.7 & 20.2 & 48.6 \\
5 to 10 & 8.6 & 16.3 & 44.9 \\
10 to 25 & 8.2 & 14.9 & 46.5 \\
25 to 50 & 7.1 & 13.4 & 43.4 \\
50 to 100 & 7.7 & 15.6 & 37.8 \\
100 and over & 7.7 & 16.4 & 30.0 \\
Total Ohio Member Banks & 9.1 & 18.1 & 46.2 \\
\hline
\end{tabular}
assets.

* Risk assets equal total assets less U. S. rovt. securitles and cash

Source: Member Bank Operating Ratios, Fourth Federal Heserve District, Federal Reserve Bank of Cleveland, 1959. 
In 1959 the total expenses of member banks in ohio with deposits in excess of $\$ 100$ million was 62.9 per cent of the total income of these banks. The total expenses for all Ohio member banks in 1959 averaged 71.0 per cent of total income, and the highest ratlo of total expenses to total income was reglstered by member banks with total deposits of less than $\$ 1$ million.

Table 21 shows, however, that the reduction in the ratio of total expense to total income of a bank does not decline steadily as total deposits increase. The increase in deposits results in a lower ratio of total expense to total income until total deposits of $\$ 10$ million are acquired. An increase in total deposits beyond $\$ 10 \mathrm{ml11}$ ion results in an increase in the ratio of total expense to total income until $\$ 50 \mathrm{million}$ in deposits are acquired. The only explanation for the higher ratio of total expense to total income for member banks with total deposits ranging from $\$ 10 \mathrm{mill}$ on to $\$ 50 \mathrm{mi} 11$ ion is the fact that bank management is forced to Increase operating expense faster than total income increases in order to attract additional deposits. Once the $\$ 50 \mathrm{milli}$ on deposit level is reached, however, the bank then benefits from the cost advantages of a larger operating base.

From the viewpoint of its influences on expenses, the interest of a bank in growing rapldly is clearly evident in the relationship between size and costs. For while the immediate result of rapid growth appears to Increase costs, the longer-run influence is to reduce costs by permitting the bank to enjoy the cost advantages of larger scale operations. 5

\footnotetext{
5 mImortance of Size and Other Factors Affecting Bank Costs," Monthly Review of the Federal Reserve Bank of Kansas CIty, April 1961, p. 3.
} 
Meaningful comparisons of cost ratios must give attention to other characteristics of the assets and llabilities of different size banks. An analysis of the net profits in relation to the total assets and total capltal accounts of Ohio member banks also reveals the greater profitabllity of larger banks. The Ohio member banis in the largest deposit classification had the highest ratio of net profits to total capltal accounts, and the second largest deposit group had the second highest ratio. In 1959 the average ratio of net profits to total capital for all Ohio member banks was 6.9 per cent, and the banis with deposits in excess of $\$ 100 \mathrm{milli}$ in averaged 9.1 per cent. The member banks with deposits ranging from $\$ 1$ to $\$ 5$ million had a better return on total capital than those with deposits ranging from $\$ 5$ to $\$ 50$ million. The group with the poorest profit record in 1959 were the member banks with deposits under $\$ 1$ million.

One of the primary reasons for the larger banks reporting a higher ratio of net profits to capital accounts was their advantage In having a smaller ratio of capital to total assets. In 1959 the average ratio of capital accounts to total assets for all Ohio member banks was 9.1 per cent. In the same period the member banks with deposits exceeding $\$ 50 \mathrm{milli}$ on had an average capltal to assets ratio of 7.7 per cent, and the least profitable member banks, those with deposits of less than $\$ 1 \mathrm{million}$, had a capital to assets ratio of 12.9 per cent.

The larger banks' earnings advantage is partially offset, however, by their lower operating earnings per dollar of assets, 
which is due chiefly to the lower interest income on loans. The return on total loans for all member banks in 1959 was 5.82 per cent, and the member banks in the $\$ 100 \mathrm{mi} 111$ on deposit class averaged 5.52 per cent return on total loans.

The highest ratio of return on loans, however, was not earned by the smallest banks. The highest average return of 5.98 per cent on total loans was earned among the banks in $\$ 25$ to $\$ 50$ million class. It is interesting to note that this same deposit class demonstrated the second poorest ratio of net profits to total capital and total assets.

Another factor adding to the lower expense ratio of the larger banis was the ratio of time deposits to total deposits. The lower ratio of time deposits to total deposits reported by the larger banks permitted these banks to pay out a smaller proportion of total income in interest to deposit holders. In 1959 all Ohio member banks held 46.2 per cent of thelr total deposits in time deposits, but the time deposits of member banks in the $\$ 100$ million deposit class represented only 30.0 per cent of their total deposits.

V. Competition In Banking in Ohio

The competition that banks in Ohio faced during the subject period resulted from the activity within the banking industry, and the growth of nonbank financial institutions during the postwar perlod. 


\section{A. Competition in Commercial Banking}

\section{Entry}

As a result of the numerous bank fallures between 1921 and 1934 the bank regulatory agencies adopted more stringent policies regarding the formation of new banks. To assure a strong banking structure increased regulation has been substituted for unrestricted competition, and the primary method of 1 imiting competition in banking is the legal restrictions placed on entry.

The legal restrictions on entry into banking are primarily the minimum capital requirements imposed by federal and state laws. Under federal law, a national bank 1 s required to have a minimum capital stock of $\$ 50,000$ in communities of 6,000 and less; $\$ 100,000$ in cities with a population ranging from 6,000 to 50,000 ; and $\$ 200,000$ in cities of 50,000 population and more. In addition, a national bank must, at the time it receives a charter, have a paid-in surplus equal to 20 per cent of $i$ ts capital stock. 6

\section{Federal Code, Annotated, Title 12, sec. 51.}

To recelve a bank charter from the state of Ohio the banking law requires that a unit bank have capital stock of at least $\$ 35,000$ in villages, $\$ 50,000$ in cities the population of which does not exceed 25,000; and a minimum of $\$ 100,000$ in citles with a population in excess of 25,000 . The Ohio banking law also requires 
a paid-1n surplus equal to 20 per cent of the capltal stock before operation of a state chartered bank may begin.?

\section{Tohio Banking Law, Annotated, 1103.10.}

The Ohio Superintendent of Banks reported that neither he nor the. Comptroller of the Currency wl11 grant permission to open a new bank in a community where there are already a sufficient number of banks in operation, and the creation of an additional bank might result in undesirable competition. 8

\footnotetext{
${ }^{8}$ Interview with the Ohio Superintendent of Banks, March 24 , 1961.
}

Although the legislat Ive and regulatory barrlers to entry into banking have some undesirable effects upon the banking structure, It is generally conceded that the benefits of such regulation outwelgh the di sadvantages.

This type of regulation has resulted in the erection of statutory barriers, behind which inefficient institum tions may placidly exist, sheltered from the competition which, in another industry, would destroy them. But that, too, is a cost deemed necessary to attain the primary objective which is to protect the banks, the depositors in the banks, and those in the community who deal with the banks.?

9Henry Harfield, "Legal Restraint on Expanding Banking Facilities: Competition and the Public Interest, "The Business Lawyer, July 1959, p. 1018. 


\section{Market Area}

The size of the market which a bank can effectively serve also provides a limitation on the extent of competition in banking. The market area which a bank serves varies directly with the size of the bank. The small bank typically makes loans only to local businesses and individuals. The larger banks usually compete for business loans outside of their own metropolitan area, but in doing so, they are interested primarily in the loan account of the larger and betterknown business firms. Thus, the size of the lender and the size of the borrower are both dominant factors in determining the size of the credit market. 10

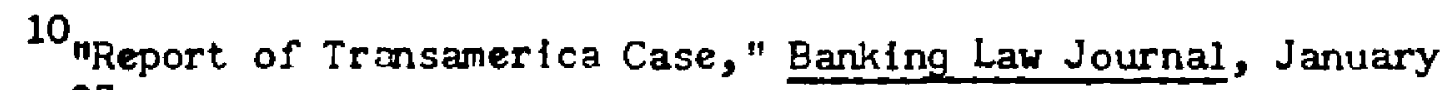
1954, p. 27.

As a result of the correlation between the size of the bank and the size of the banking market, the growtr objective ranks high among the goals of bank management. The limits to which a bank may influence Its growth rate, however, are much narrower than is the case for firms in most other industries. The growth of bank assets and deposits is dependent upon the expansion of bank reserves which, In turn, is regulated and controlled by the action of the Federal Reserve System. Other 11mitations to growth over which bank management has 11 ttle control are federal and state regulation of the operation of branch offices, the kinds and quality of assets acquired, and the Interest paid on deposits. 
3. Price Competition

The rates which banks charge thelr customers and pay for deposits do not appear to be a major competitive weapon. ${ }^{11}$ The rate

${ }^{11}$ Clay J. Anderson, "Competitive Factors in Business Loans," Business Loans of Amerlcan Banks, Ed. B. 1.. Beckhart (New York: Ronald Press Company, 1956), p. 305.

policy adopted by banks entering a market is the going rate. A bank attempting to charge a higher rate would place itself at a competitive disadvantage, and to charge a lower rate would invite retallatory action from competitors. Professor Robinson contends that the rate charged for loans is not the paramount concern of bank customers.

As said before, most customers are not keenly interested in rates; their chief interest is in not being treated unfalrly. While rates are a legitimate form of competitive activity, there are other and possibly better grounds for advancing the competitive case: better service, more flexible adjustment of credit terms to the true needs of the borrowgr, help in promoting more business for the customers. 12

\section{Robinson, Management of Bank Funds, p. 124 .}

In those cases where price competition does exist between banks, rate cutting is more likely to be disguised in the form of lowering the standards used to determine the rate to which a particular customer is entitled. 13

\section{3} Ander son, p. 306. 
The rates which banks charge for loans, however, are not determined solely by management. The interest rates charged by banks are also influenced by the monetary policies and actions of the Federal Reserve System. As a result, banking somewhat resembles a public utility in that the rates which they charge are partly determined by regulatory authorfties, rather than solely by supply and demand forces in the market. Professor Bogen points out an important difference, however, between the monetary policy of the Federal Reserve System and the rate-making policy of a public utillty commission.

But regulatory authorities set utility rates at levels that are designed to provide a falr return on the investment, and so to attract new capital as needed to the industry. The Federal Reserve authorities, by contrast, seek to promote economic growth and price stability by their credit policies with little or no regard to the impact of their actions upon the earning power of commercial banks.14

14 Bogen, Adequacy of Commercial Bank Earnings, p. 7.

Although there is little, if any, price competition among banks in the same market area, there are, however, differences in interest rates among separate markets. Interest rates on bank loans tend to be lower and more flexible in large cities than in small towns. This difference in rates reflects, in part, the lower operating costs of large banks and the type of customer to which the larger metropolitan banks make loans. The banks in the large cities deal with business firms that have several alternative sources of supply 
for short-term and intermediate-term capital. The loan rates of small banks located in small towns are typlcally hlgher and more rigid. This results from the higher operating costs which these banks experience, and the fact that the small business firms which these banks serve have few, if any, alternative sources of supply. 15

15 David A. Alhadeff, Monopoly and Competition in Banking, (Berkely and Los Angeles, University of Callfornia Press, 1954), p. 219.

As a result of the similarity of rates charged by banks which share the same market, many students of banking have asserted that collusion exists among the banks and that the means of enforcing it is the clearinghouse agreement which banks enter into. Professor Chandler in his examination of bank competition found little evidence to sustain such an argument.

It is impossible to ascertain the extent to which the interest rates on loans to customers are fixed by interbank collusion. Clearinghouse agreements are singularly silent on this point. There are probably several reasons for this silence. In the first place, the publication of such an agreement would evoke unfavorable customer reactions. In the second place, any uniform rate agreed upon could hardly be Imposed upon those borrowers with ready access to the open market or to distant banks. And, finally, an agreement on rates to be charged borrowers unable to resort to sources outside the areas covered by the clearinghouse agreement is probably considered unnecessary in that the majorlty of cases the rates on these loans are already flxed by custom of long standing. 16

16 Lester V. Chandler, Monopolistic Elements In Commercial Banking," Journal of Political Economy, February 1938, p. 11. 
4. Competition in jervices

Competition does exist in bankin!; however, the primary area of competition between banks is in the services which are provided customers. ${ }^{17}$ The true measure of the degree of competition in a bankp. 18. ${ }^{17}$ Annual Report of the Comptroller of the Currency, 1956 , ing market is the convenience, the range, and the quality of the services which are made available to customers.

A study conductec' at Western Reserve [iniversity by William C. Stewart revealed that the most important factor in the selection of a bank by a corporation is the services which a bants is capable of providing.

It seems quite apparent that the bank which bullds a good reputation in the business community, which, keeps its fences in sood repair by community service and frequent contact with the corporation, and wtich keeps up to date with the latest services which $c$ an be providec to its customers, gets the business. 18

\footnotetext{
18 William C. Stewart, "How Business Picks Banks," Burroughs Clearing House, January 1960, p. 33.
}

As a result of the demand for increased services by business customers many banks have established staff specialists in particular Industries in order to attract the business of large corporations. Banks located in predominantly agricultural areas have placed agricultural specialists on their staffs in order to attract the business of farmers. 
As a result of the demand for a broader range of bank services and the competition among banks to provice these services, the need has arisen for banks to become larger and to acquire a larger share of the existing market. This need for a larger operating base and market share is a direct outgrowth of the increased costs which result from offering new and diversfified services. Without a minimum operating base the individual banks cannot afford to uncertake the services which customers desire, and the outcome is an inability to compete effectively and the eventual loss of income.

B. Competition Between Banks and Other Savins and Lending Institutions

Banks in Ohio have received a substantial amount of competition from other savings and lending institutions in Ohio during the postwar period. The growth of many of these institutions was a result of either the inablity or the unisilingness of the banks in Ohio to provide services which the public desired.

Thus, if we stand back and appralse our competition with some degree of detachment, we would have to acknowledge that these competitors of ours in the fields of savings and credit were initiated and their growth stimulated because we commercial bankers falled to provide a desired service--or failed to provide it on desired terms. Perhaps we could not provlde the service; perhaps we should not have provided the service; but in any event we did not provide it.19

${ }^{19}$ Gaylord A. Freeman, Mutual Competition (Chicago, I11.: The First National Bank of Chicaco, 1950), p. 35. 
1. Savings and Loan Associations

The savings and loan associations were the most aggressive nonbank competitors in Ohio during the postwar period. Table 22 presents the total number of savings and loan associations in ohlo during the postwar period, and the total assets, first mortgage loans, and savings capital of the associations.

In the postwar period the number of savings and loan associations in operation in Ohio was reduced by 8.50 per cent, but the average assets per association increased from $\$ 2,134,000$ in 1945 to $\$ 10,711,000$ in 1959 . In 1959 ohio ranked third in the nation in the number of associations in operation. In the same year the total assets of savings and loan associations in ohio were second only to California, and the per capita assets in savings and loan associations in Ohio also placed second nationally. 20

${ }^{20}$ Savings and Loan Fact Book, 1960 (Chicaco, I11.: United States Savings and Loan League, 1960), p. 71.

The areas in which the savings and loan assoclations in ohio actively compete with banks are real estate loans and savings deposits. During the po:twar period the savings and loan associations in onio were quite successful in competing for savings deposits. In 1945 the time deposits of all banks in Ohio exceeded the savings capital of all savings and loan associations in Ohio by 120 per cent, but by 1959 the savings capital of the savings and loan associations exceeded bank time deposits in the state by 29.76 per cent. 
TAELE 22

NUMBER AND SELECTED BALANCE SHEET DATA OF ALL SAVINGS AND LOAN ASSOCIATIONS IN OHIO $1945-1959$

(Nillions of Dollars)

\begin{tabular}{|c|c|c|c|c|}
\hline Year & Number & Total Assets & $\begin{array}{l}\text { 1st Mortgage } \\
\text { Loans }\end{array}$ & $\begin{array}{l}\text { Savings } \\
\text { Capltal } \\
\end{array}$ \\
\hline 1945 & 635 & $\$ 1,355$ & 765 & $\$ 1,111$ \\
\hline 1946 & 627 & 1,535 & 965 & 1,324 \\
\hline 1947 & 622 & 1,689 & 1,145 & 1,454 \\
\hline 1948 & 615 & 1,815 & 1,265 & 1,577 \\
\hline 1949 & 611 & 1,953 & 1,411 & 1,694 \\
\hline 1950 & 609 & 2,151 & 1,590 & 1,829 \\
\hline 1951 & 607 & 2,419 & 1,794 & 2,051 \\
\hline 1952 & 605 & 2,769 & 2,068 & 2,362 \\
\hline 1953 & 601 & 3,111 & 2,364 & 2,676 \\
\hline $195 \mathrm{~L}$ & 600 & 3,504 & 2,688 & 3,027 \\
\hline 1955 & 596 & 4,041 & 3,152 & 3,468 \\
\hline 1956 & 593 & 4,059 & 3,529 & 3,925 \\
\hline 1957 & 585 & 4,961 & 3,881 & 4,356 \\
\hline 1958 & 582 & 5,463 & 4,295 & 4,771 \\
\hline 1959 & 581 & 6,225 & 4,994 & 5,354 \\
\hline
\end{tabular}

Source: Bureau of the Census, United States Department of Commerce, Statistical Abstract of the United States (Washington, D.C., United States Government Printing Office, 1946-1959), United States Savings and Loan League, Savings and Loan Fact Book, 1960. 
There are a number of reasons clted for the postwar success of savings and loan associations in attracting personal savings. Some commercial bankers argue that the primary reason for the success of the savings and loan associations is the alleged inequallty in taxation between the associations and the banks.

Under the current law a commercial bank may accumulate a bad debt reserve equal to its total loans outstanding multiplied by a loss ratio. The loss ratio is determined by one of two methods: either an average of the actual loss experlence of the bank during the twentyyear period Immediately preceding the present tax year, or the actual loss experience of the bank during the twenty-year period starting with 1927. The maximum amount that may be added to the bad debt reserve during any one year is an amount which will bring the accumulated bad debt reserve to three times the averape loss ratio multiplied by the total loans currently outstanding.

In the case of savings and loan associations the bad debt reserve is computed in the same manner as described for commercial banks if the sum of the surplus, reserves, and undivided profits is equal to or in excess of 12 per cent of the total savings capital; however, if these three items are not equal to 12 per cent of the savings capital the savings and loan associations are permitted to deduct any amount from taxable income as an addition to reserves for bad debts until the sum of the surplus, reserves, and undivided profits 
equals 12 per cent of savings capital. ${ }^{21}$ In addition, a savings and

${ }^{21}$ Federal Taxes, Volume I (Englewood, N.J.: Prentice-Hall Pub1ishing Company, 1961), p. 4869.

loan association is allowed to treat all amounts pald to depositors or shareholders or credited to their accounts as an expense before determining taxable income. The effect of this provision is that a savings and loan association, by paying out sufficient interest or divicends, can keep the aggregate of its surplus, undivided profits, and reserves below 12 per cent of its savings capital, and thus permanently avoid the payment of federal income tax. 22

22 Paul D. Lagomarcino, "The Impact of 12 Per cent Reserve Income Tax Provision Upon the Banking Structure, "Banking Law Journal, November 1958 , p. 922.

Spokesmen for commercial banking have contended that this difference in tax treatment between savings and loan associations and banks is the reason the savings and loan associations are capable of paying higher dividends or interest for personal savings, 23 There

${ }^{23}$ Ray M. Gidney, "Growth of the Nation's Banking Institutions," The commercial and Financial Chronicle, October 2, 1958, p. 25.

are, however, those in commercial banking who refute this argument.

We are all familiar with the handicaps of commercial banks

in competing for this [time deposits] business. The one we hear about the most is tax inequality. This is a real disadvantage, of course, but the figures show that it is nowhere as important relatively, as many persons assume. Its elimination would not solve the bank's competitive 
problem by any means. . - by far the greatest di sadvantage is the fact that other institutions pay savers appreclably higher rates of return and are thereby able to attract more savings. At the moment this is due in part to the 3 per cent celling on interest payments by commercial barks but pany banks are still paying less than the ceiling rate. 24

$2 L_{E}$. Sherman Adams, "Measures to Sustain Banks' Profit Position," The Commercial and Financial Chronicle, December 10, 195\%, p. 14.

One reeognized banking expert stated that "convenience, rate of return paid, services rendered and aggressive promotion determine the distribution of savings funds among financial institutions." 25

25 Bogen, The Competitive Position of Commercial Eanks, p. 32.

As a result of the ceiling imposed upon the rate of interest that conmercial banks may pay for time deposits, the banks are unable to compete with savings and loan associations by offering a higher rate of interest for deposits. The most effective means by which banks compete with savings and loan associations for savings accounts is by offering a more complete financial service to the depositor than is offered by the savings and loan associations.

Banks and savings and loan associations in Ohio also compete for residential real estate loans. In 1959 the savings and loan associations in Ohio held 57.22 per cent of the total home mortgage loans in Ohio, and the banks in Ohio accounted for 18.97 per cent of the 
total. ${ }^{26}$ The ablifty of the banks in Ohio to increase the proportion

${ }^{26}$ Savings and Loan Fact Book, 1960, p, 42.

of the real estate loans which they hold will depend upon their ablity to attract additional time deposits. Mortgage loans have much longer maturities than other classes of loans made by banks, and they have limited or no marketability. Hence they have been regarded traditionally as suitable only for the investment of a part of a commercial bank's time deposits.

The future competitive position of commercial banks in mortgage lending will depend chlefly on the volume of savings deposits they will attract. The ready availability and relatively favorable yields of fered by mortgages continue to favor the investment of a rising proportion of savings deposits gains in non-farm mortgage loans. 27

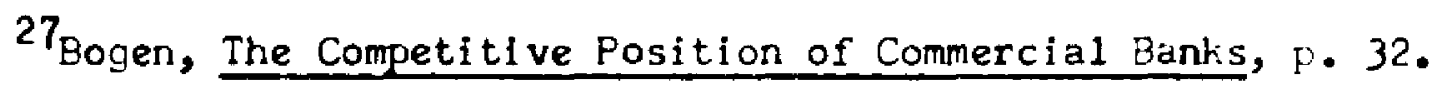

Thus the competition for real estate loans between savings and loan assoclations and banks in Ohio is closely linked with the competition which these institutions conduct to attract savings deposits.

2. Credit Unions

The credit unions in operation in Ohio during the postwar period have also provided competition for banks. The areas in which the credft unions compete with banks are savings deposits and consumer loans. Table 23 presents the total number of credit unions in 
Ohio during the postwar period and the total assets of these organizations.

The total assets of credit unions in ohio in 1959 shows that credit unions are not as important a competitor of tidits is the savings and loan associations. The growth of credlt unions in ohio during the postwar period, however, has been rapid. During the $11_{1}-$ year period following horld war IT, 565 additional credit unions were organized in Ohto, and the total assets of these organizations increased from $\$ 24,223,000$ in 1945 to $\$ 279,011,000$ in 1959 .

As a result of the growth in the creiit union movement, some commercial banks have attempted to meet the competition of credit unions by offering the same services within industrial plants or ad jacent to them. 28

28 "Answer to credit unions; the same services on the same premises," Banking, July 1959, p. 64.

\section{United States Savings Bonds}

The sale of United States Savinis Bonds to the public has also served as competition for the savings deposits of commercial banks in Ohio. The annual sale of savings bonds in Ohio has been rather stable throughout the postwar period as demonstrated by Table 24. Unfortunately, the net amount of savings in onio held in United States Savings Bonds is not available. The Treasury Department discontinued reporting redemptions by states after 1947. 
TABLE 23

MMMER AND TOTAL ASSETS OF ALL CREDIT UNIONS IN OHIO 1945-1959

(Thousands of Dollars)

\begin{tabular}{lcc}
\hline \hline Year & Number & Total Assets \\
\hline 1945 & 567 & $\$ 24,223$ \\
1946 & 565 & 28,510 \\
1947 & 571 & 35,041 \\
1948 & 585 & 42,766 \\
1949 & 614 & 48,729 \\
1950 & 663 & 60,170 \\
1951 & 706 & 74,156 \\
1952 & 751 & 95,141 \\
1953 & 783 & 117,937 \\
1954 & 856 & 137,330 \\
1955 & 945 & 164,310 \\
1956 & 988 & 194,016 \\
1957 & 1, olt5 & 220,868 \\
1958 & 1,082 & $242,1,12$ \\
1959 & 1,132 & 279,011 \\
\hline
\end{tabular}


TARLE 24

ANNIAL PURCHASE OF UNITEI) STATES SAVINCS BONIS IN OHIO $1945-1960$

(Thousands of Dollars at Issue Price)

\begin{tabular}{lcr}
\hline Year & $E$ and $H$ Bonds ${ }^{1}$ & $\begin{array}{c}F, \bar{J}, \mathrm{~J} \\
\text { and } \\
K \text { Bond s }\end{array}$ \\
\hline 1945 & $\$ 600,474$ & $\$ 172,798$ \\
1946 & 415,305 & 180,198 \\
1947 & 242,907 & 166,213 \\
1948 & 226,328 & 129,307 \\
1949 & 252,603 & 137,676 \\
1950 & 230,196 & 96,532 \\
1951 & 208,244 & 71,505 \\
1952 & 224,132 & 38,411 \\
1953 & 260,411 & 29,348 \\
1954 & 304,318 & \\
1955 & 342,104 & \\
1956 & 350,318 & \\
1957 & 306,608 & \\
1958 & 311,038 & \\
1959 & 283,876 & \\
\hline
\end{tabular}

1 jeries $H$ bonds have been issued only since June $1,1952$.

${ }^{2}$ Series $J$ and $K$ bonds were first issued on May 1 , 1952 to replace Series $F$ and $G$ bonds. Issuance of series $J$ and $K$ was discontinued in 1954 .

Source: United States Treasury Department, Annual Report of the Secretary of the Treasury on the State of Finances (Washington, D.C.: United States Government Printing office, 1946-1959). 
4. Consumer Finance Companies

During the postwar period banks in Ohio began to compete with specialized lenders for consumer loans. The relatively high rate of return, the successful credit experience, and the high level of employment made consumer loans attractive for banks.

The consumer loan companies proved to be capable competitors during the postwar period as demonstrated by Table 25. A portion of the funds which the consumer loan companies have available, however, are borrowed from commercial banks, and as a result the competition is significantly reduced.

A large portion of the funds loaned to consumers by specialized lenders is borrowed from commercial banks, and so is reflected in the business loans of the latter. As with factors and commercial finance companies, the specialized consumer lending institutions act as middle men between bank and borrower. They secure a large part of their funds from banks at relatively low rates, and lend them to consumers at the relatively high rates obtainable for consumer credit.29

${ }^{29}$ Bogen, The Competitive Position of Commercial Banks, $p .24$.

\section{Life Insurance Companies}

A portion of the funds in which onio citizens pay in the form of 1 ife insurance and annuity premiums represent personal savings and might otherwise have been placed in savings accounts. The annual amount of ordinary 1ife insurance premlums, as shown in Table 26, pald by Ohio citizens to domestic or foreign insurance companies increased in each year of the postwar period. The premiums paid for annuities also increased but at a slower rate. 
TABLE 25

NUMBER OF OFFICES AND TOTAL ASSFTS OF ALL CONSUMER LOAN COMPANIES IN OHTO

$1946-1959$

(Thousands of Dollars)

\begin{tabular}{ccc}
\hline Year & $\begin{array}{c}\text { Number of } \\
\text { Offices }\end{array}$ & Tota1 Assets \\
\hline 1946 & 517 & $\$ 128,000$ \\
1947 & 533 & 115,000 \\
1948 & 555 & 135,000 \\
1949 & 576 & 151,000 \\
1950 & 611 & 172,000 \\
1951 & 655 & 204,000 \\
1952 & 698 & 227,000 \\
1953 & 720 & 251,000 \\
1954 & 757 & 269,000 \\
1955 & 802 & 283,000 \\
1956 & 874 & 318,000 \\
1957 & 920 & 347,000 \\
1958 & 947 & 368,000 \\
1959 & 983 & 380,000 \\
\hline
\end{tabular}

Source: SSecurities Division, Analysis and Recapulation of Reports Filed by Offlces Licensed Under the Ohio Small Loan Act (Columbus, Ohio: Ohio Department of Commerce, 1946-1959). 
TABLE 26

PREMIUMS RECEIVEN IN OHTO BY LIFE TISLIRA:ICE COMPANIES AUTHORIZED TO OPERATE TU OHIO

1945-1.959

(Thous:nds of Dollars)

\begin{tabular}{lcr}
\hline Year & $\begin{array}{c}\text { Ordinary Life } \\
\text { Insurance }\end{array}$ & Annulties \\
\hline 1945 & $\$ 193,359$ & $\$ 31,145$ \\
1946 & 221,746 & 37,021 \\
1947 & 225,377 & 43,763 \\
1948 & 238,253 & 51,975 \\
1949 & 247,300 & 52,247 \\
1950 & 258,688 & 58,610 \\
1951 & 273,686 & 74,519 \\
1952 & 295,007 & 74,661 \\
1953 & 314,224 & 85,188 \\
1954 & 332,883 & 85,375 \\
1955 & 357,550 & 80,103 \\
1956 & 382,468 & 85,673 \\
1957 & 411,240 & 89,374 \\
1958 & 432,327 & 86,789 \\
1959 & 454,876 & 86,715 \\
\hline
\end{tabular}

Source: Superintendent of Insurance, Annual Report (Columbus, Chio: Ohio Department of Insurance, 1950 and 1960). 
Life insurance companies also compete with commercial banks in real estate loans. In $1959,4.0$ per cent of the total home mortgages in ohio were held by life insurance companies. 30

$$
{ }^{30} \text { Savings and Loan Fact Book, } 1960,0.42 .
$$

Life insurance companies al so are active in business loans; however, the long-term loans are of greater interest to these organizations than the short-term and intermediate-term loans.

Commercial banks, it is apvarent, are content to specialize in short-term and intermediate-term financing of business. They leave the long-term flnancing almost entirely to life insurance companies and pension funds, which have been willing to accept relatively low yields on long-term corporate obligations. . . . It is doubtful that commercial banks will find long-term, as distinct from short and intermediate term, lending to business attractive unless they are to receive a much larjer annual increment of savings deposits in the future. Even in that event, mortgage lending could prove more suitable as a large-scale investment outlet for such funds than would corporate bonds. 31

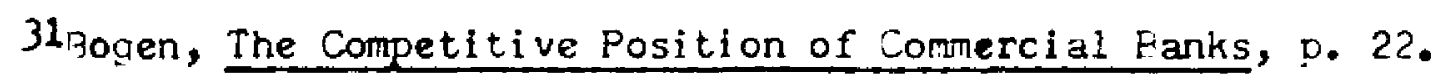

6. Investment in Corporate Securities

The postwar increase in purchases of common stock by the general public has also created a drain on the savings deposits of banks. Due to the lack of statistics, however, it is impossible to measure the amount of competition that common stock Investment provided for the banks in Ohio. 32

32 The writer contacted the odd-lot brokeraye house of Carlisie and Jacquelin, the Division of Trading and Exchanges of the Securities 
and Exchange Commission, and the Securities Division of the Ohio Department of Comnerce in an attempt to locate statistics on the odd-1ot and secondary sales of stock in Ohio diring the postwar period. Each of these organizations replied that they did not collect such statistics, and they had no knowledge of the existence of such statistics.

One of the more popular methods of investing in common stock is through the purchase of shares in an open-end investment company. From 1956 to 1959 the total value of open-end investment company stock purchased in Ohio increased from $\$ 47,405,000$ to $\$ 82,146,000.33$ The

${ }^{33}$ Statistics concerning the value of sales of open-end investment company stock by states were not collected until 1956. Investment Companies--A Statistical Sumary, 1940-1959 (New York: National Association of Investment Companies, 1960), p. 24.

open-end investment companies have also developed a number of convenient programs for investors with special requirements. 34

34 Arthur Wiesenberger, Investment Companies (New York: Arthur Wiesenberger and Company, 1960), p. 105.

VI. SUMMARY

The 20 largest banks in Ohio continued to control the majority of bank resources in Ohio throughout the postwar period, but the portion of the total resources these major banks controlled remained nearly unchanged from 1945 to 1959. The total assets of the 20 largest banks were more evenly distributed among all 20 banks in 1959 than they 
had been in 1945, and as a result the concentration of resources exerclsed by the 10 largest banks dec1ined between 1945 and 1959.

The geographic concentration of bank resources and bank deposits in Ohio also remained stable from 1945 to 1959. Throughout the postwar period the 20 largest banks in Ohio were located in the eight metropolitan counties, and the comblned deposits of all banks in the eight metropolitan counties was equal to 70 per cent of the total bank deposits in Ohio.

In comparison, however, with the entire nation the state of Ohio in 1959 had less concentration of bark resources than the rest of the country.

The economies of large scale banking in Ohio become evident when the ratio of total expense to total income of different size banks is examined. Another inducement to conduct bank operations on a larger scale is the above average ratio of net profit to total capital recelved by the largest banks. The economies gained as a result of large scale banking, however, are not present at all levels of deposit growth. Higher ratios of total expense to total income and a lower return on total capital are incurred at certain levels of deposit growth. In 1959 Ohio member banks with depostts in excess of $\$ 50 \mathrm{milli}$ on benefitted most from a larger scale of operation. The competition between banks is conducted in a manner which results in greater competitive advantage to the bank capable of providing the most desirable services. As a result of the demand for increased services, the baris must attain a minimum scale of operation 
before the services can be offered profitably. This has resulted in keen competition between banks to attract additional demand and time deposits.

The nonbank financial institutions in Ohio have provided increased competition for personal savings. The savings and loan associations in Ohio have been the most aggressive competition for the banks. The credit unions, United States Savings bonds, life insurance companies, and common stock investment have also challenged the banks for personal savings, but the threat has not been as serious as that provided by the savings and loan associations. The primary method by which banks attempt to compete with these instftutions is by providing more services to customers than the competitors are capable or willing to make avallable.

Many of the nonbank financial institutions also compete with banks in Whio for real estate and consumer loans. The savings and loan associations provide the strongest competition in real estate loans, and in 1959 these institutions held the majority of all home mortgage loans in Ohio. The ability of the banks in Ohio to Increase their proportion of total real estate loans depends upon their ability to attract additional time deposits, and again they face the savings and loan associations as competitors.

The credit unions provide competition in consumer loans, but as of 1959 the total resources of credit unions in Ohio equalled less than 3 per cent of total bank resources. The consumer finance companies a1so provide competition, but much of the capital loaned 
by these organizations is borrowed from banks; therefore, they act as middlemen between the bank and the borrower.

The primary means of competing with other banks and nonbank financial instltutions in Ohfo during the postwar period has been to promote the services of the bank. This has resulted in the need for a larger operating base and a larger share of the banking market in order to absorb the cost of additional services. The effect of this has been a reduction in the number of banks and an increase in the average size of the remaining banks. 
CHAPTER IV

BRANCH, GROIP, AND CHAIN BANKING IN

OHIO DURING THE POSTWAR PERIOD

\section{The Growth of Branch Banking in Onio}

In Chapter II it was noted that the banking structure in Ohio during the postwar period was characterized by a steady decline in the number of banks and a constant increase in the number of banking offices (see Tables 1, 3, and 4). The explanation of these opposing trends lies in the transformation of the banking structure in which the number of branch banks in ohio by 1959 exceeded the number of banks. The additi onal branches resulted from the establistment of new branches as well as the conversion of independent banks to branch offlces of larger banks. It is this latter trend which was primarily responsible for the decline in the number of banks in Ohio during the postwar period.

\section{A. Increase in Branch Banks}

The annual increase in the number of branch banks in operation in Ohio durling the postwar period is presented in Table 27. It is aparent that the rapid growth in branch operations took place after 1950, and the period from 1955 to 1959 provided 62.35 per cent of the entire increase in branch operations of all banks in Ohio during the posturar period. 
TABLE 27

NUMBER OF BRANCH OFFICES ESTABLISHED BY ALL, BANKS, NATIONAL BANKS, AND STATE BANKS IN OHIO

$$
\text { 1945-1959 }
$$

\begin{tabular}{|c|c|c|c|}
\hline Year & $\begin{array}{l}\text { Branch offices } \\
\text { Establi shed } \\
\text { by All Banks }\end{array}$ & $\begin{array}{l}\text { Branch Offices } \\
\text { Establi shed by } \\
\text { Nati onal Banks }\end{array}$ & $\begin{array}{l}\text { Branch Offices } \\
\text { Establi shed } \\
\text { by State Banks }\end{array}$ \\
\hline 1945 & 1 & 1 & \\
\hline 1946 & 2 & 1 & 1 \\
\hline 1947 & 13 & 8 & 5 \\
\hline 1948 & 15 & 6 & 9 \\
\hline 1949 & 11 & 5 & 6 \\
\hline 1950 & 11 & 5 & 6 \\
\hline 1951 & 20 & 16 & 4 \\
\hline 1952 & 25 & 13 & 12 \\
\hline 1953 & 37 & 27 & 7 \\
\hline 1954 & 35 & 20 & 8 \\
\hline 1955 & 37 & 21 & 15 \\
\hline 1956 & 66 & 42 & 24 \\
\hline 1957 & 57 & 32 & 24 \\
\hline 1958 & 60 & 30 & 30 \\
\hline 1959 & 47 & 22 & 25 \\
\hline Total & 439 & 249 & 176 \\
\hline
\end{tabular}

Source: Federal Reserve Bulletin, April and May issues, 1946-1960. 


\section{B. Number of Banks Operating Branch Banks}

Growth in branch banking may also be measured in terms of the number of banks which operate branch of fices. Table 28 presents the number of banks in Ohlo with and without branch operations.

\section{Al1 Banks}

During the postwar period the number of banks in Ohio with branch operations increased from 41 in 1945 to 176 in 1959. Expressed as a percentage of the total number of banks in Ohio, the banks which maintained branch offices rose from 6.05 per cent of the banks in ohio In 1945 , to 29.76 per cent of the total in 1959.

The increase in the number of banks with branch operations, however, was not uniform throughout the postwar perlod. From 1945 to 1950 only 16 additional banks established branch offices, and this increase represented 11.09 per cent of the entire postwar increase. From 1950 to 1955 branch offices were opened by 51 additional banks in Ohio. By the end of $1955,17.02$ per cent of all banks in Ohio maintained branch facilities. During the period 1955 to 1959, 68 additlonal banks established one or more branch offices, and this increase accounted for 52.99 per cent of the entire postwar growth In the number of banks with branch operations.

\section{National Banks}

The number of national banks in Ohfo with branch facilities increased from a total of nine in 1945 to 82 in 1959. As a proportion of the total number of national banks in Ohio, the national banks 
TABLE 28

ALl BANKS, NATIONAL BANKS, AND STATE BANKS

IN OHIO WITH AND WITHOUT BRANCH OFFICES

$1945-1959$

\begin{tabular}{|c|c|c|c|c|c|c|}
\hline \multirow[b]{2}{*}{ Year } & \multicolumn{2}{|c|}{$\mu 11$ Banks } & \multicolumn{2}{|c|}{ National Banks } & \multicolumn{2}{|c|}{ State Banks } \\
\hline & $\begin{array}{l}\text { Tumber of } \\
\text { Banks with } \\
\text { Branches }\end{array}$ & $\begin{array}{l}\text { Number of } \\
\text { Banks with- } \\
\text { out Branches }\end{array}$ & $\begin{array}{l}\text { Number of } \\
\text { Banks with } \\
\text { Branches }\end{array}$ & $\begin{array}{l}\text { Number of } \\
\text { Banks with- } \\
\text { out Branches }\end{array}$ & $\begin{array}{l}\text { Number of } \\
\text { Banks with } \\
\text { Branches }\end{array}$ & $\begin{array}{l}\text { Number of } \\
\text { Banks with- } \\
\text { out Branches }\end{array}$ \\
\hline $\begin{array}{l}1945 \\
1946 \\
1947 \\
1948 \\
1949\end{array}$ & $\begin{array}{l}41 \\
41 \\
41 \\
44 \\
50\end{array}$ & $\begin{array}{l}636 \\
635 \\
627 \\
622 \\
611\end{array}$ & $\begin{array}{r}9 \\
9 \\
11 \\
12 \\
14\end{array}$ & $\begin{array}{l}231 \\
230 \\
229 \\
229 \\
227\end{array}$ & $\begin{array}{l}32 \\
30 \\
30 \\
32 \\
36\end{array}$ & $\begin{array}{l}390 \\
390 \\
384 \\
380 \\
372\end{array}$ \\
\hline $\begin{array}{l}1950 \\
1951 \\
1952 \\
1953 \\
1954\end{array}$ & $\begin{array}{l}57 \\
61 \\
67 \\
85 \\
96\end{array}$ & $\begin{array}{l}602 \\
595 \\
584 \\
560 \\
539\end{array}$ & $\begin{array}{l}18 \\
21 \\
24 \\
36 \\
41\end{array}$ & $\begin{array}{l}223 \\
218 \\
214 \\
199 \\
193\end{array}$ & $\begin{array}{l}39 \\
40 \\
43 \\
48 \\
54\end{array}$ & $\begin{array}{l}370 \\
370 \\
363 \\
355 \\
341\end{array}$ \\
\hline $\begin{array}{l}1955 \\
1956 \\
1957 \\
1958 \\
1959\end{array}$ & $\begin{array}{l}107 \\
1 y_{4} \\
147 \\
164 \\
176\end{array}$ & $\begin{array}{l}517 \\
485 \\
491 \\
443 \\
413\end{array}$ & $\begin{array}{l}47 \\
61 \\
65 \\
76 \\
82\end{array}$ & $\begin{array}{l}183 \\
168 \\
164 \\
152 \\
140\end{array}$ & $\begin{array}{l}59 \\
71 \\
80 \\
87 \\
93\end{array}$ & $\begin{array}{l}331 \\
315 \\
301 \\
290 \\
272\end{array}$ \\
\hline
\end{tabular}

Source: Annual Report of the Federal Deposit Insurance Corporation, 1946-1960. 
operating branch offices equalled 3.75 per cent of the total in 1945 and 36.93 per cent in 1959.

The increase in the number of national banks with branch banks followed an irregular growth pattern during the postwar period. From 1945 to 1950 only nine additional national banks established branch offices. In the final four years of the subject period 35 national banks developed their first branch operation, and this increase represented 48.61 per cent of the entire 14 -year growth. National banks also accounted for 57.45 per cent of all banks in Ohio which established their first branch office between 1945 and 1959.

\section{State Banks}

The proportion of state chartered banks in Ohio with branch facilities rose from 7.58 per cent of the total number of state banks in 1945 to 25.48 per cent in 1959. The perlod in which the largest number of state banks undertook branch operations during the postwar period was also 1955 to 1959. During those four years 55.73 per cent of the total postwar increase in state bank branch offices took place.

Although from 1945 to 1959 the national banks provided the larger proportion of the total increase in the number of banks with branch operations in ohio, the state banks continued to account for the largest number of banks with branch offices. The gap between state and natlonal banks was narrowed conslderably, however, during the 14-year period. In 1945 the state banks in Ohio accounted for 
78.04 per cent of all banks with branch operations in the state. By 1959, however, state banks with branch facilitles represented only 52.21 per cent of the Ohio total.

\section{Pattern of Branch Banking in Ohio}

It is evident from the preceding analysis that the branch banks in operation in Ohio in 1959 were under the control of a larger proportion of the total banks in ondo than at the beginning of the postwar perlod. To provide a better understanding of the pattern of branch banking in Ohio during the postwar perlod, however, attention must also be focused upon the proportion of branch banks operated by the largest banks in the state and the geographic dispersion of branch banks in Ohto.

A. The Control of Branch Banking in Ohio Exerclsed by the 20 Largest Banks

Tables 29 and 30 present the number of branch offices operated by the 20 largest banks in Ohio in 1945 and 1959. 1. The Largest Bank in Ohio

The Cleveland Trust Company was the largest bank in Ohio in terms of total assets as well as total branch offices in both 1945 and 1959. In 1945, 46 branch of flces were belng operated by The Cleveland Trust Company and this number equalled 26.29 per cent of all branch banks in Ohio. In 1959 the Cleveland Trust Company had expanded Its branch offices to 68 ; however, the proportion of the 
total branch offices in Ohio which the Cleveland bank accounted for had declined to 11.37 per cent.

2. The Five Largest Banks in Ohio

In 1945 the five largest banks in the state operated a total of 82 branches which represented 46.85 per cent of all branch banks in Ohio. The flve leading banks in 1959 controlled a total of 152 branch offices, but they accounted for only 25.41 per cent of the Ohio total.

3. The 10 Largest Banks in Ohio

In 1945 two of the major banks in ohio did not operate any branch offices. The remaining elght banks operatec a total of 108 branch offices, and they accounted for 61.71 per cent of all branch offices in Ohio.

During the following 14 years all 10 of the largest banks in Ohio undertook branch operations, and in 1959 the 10 major banks controlled a total of 223 branch banks. This total, however, represented only 37.29 per cent of all branch offlces in Ohio in 1959.

4. The 20 Largest Banks in Ohlo

At the beginning of the postwar perlod the 20 largest banks in ohio operated a total of 132 branch offices as compared to a total of 298 branch offices in 1959.

In 1945 the 20 major banks in Ohic operated 75.42 per cent of the total branch banks in Ohio, and in 1959, 49.83 per cent of the 
MUMBER OF BRANCH BANKS OPERATED BY THE 20 LARCEST BANKS IN OHIO IN 1945

Name of the Bank
$\begin{aligned} & \text { Number of } \\ & \text { Branches }\end{aligned}$
$\begin{aligned} & \text { Total Branch } \\ & \text { Banks Cleveland Trust Company }\end{aligned}$
The National City Bank of Cleveland
The Central National Bank of Cleveland
The Toledo Trust Company
The Fifth Third Union Bank of Cincinnati
The Five Largest Banks in Ohio

Source: Polk's Bankers Encyclopedia, March 1946. 


\begin{tabular}{|c|c|c|}
\hline Name of Bank & $\begin{array}{l}\text { Number of } \\
\text { Branches }\end{array}$ & $\begin{array}{l}\text { Percentage of } \\
\text { Total Branch } \\
\text { Banks in Ohio }\end{array}$ \\
\hline $\begin{array}{l}\text { The Cleveland Trust Company } \\
\text { The National City Bank of Cleveland } \\
\text { The Central National Bank of Cleveland } \\
\text { The Ohio National Bank of Columbus } \\
\text { The First National Bank of Cincinnati }\end{array}$ & $\begin{array}{l}68 \\
18 \\
31 \\
18 \\
17 \\
\end{array}$ & 11.37 \\
\hline The 5 Largest Banks in Ohio & 152 & 25.41 \\
\hline $\begin{array}{l}\text { The Society National Bank of Cleveland } \\
\text { The Fifth Union Trust Company of Cincinnati } \\
\text { The Toledo Trust Company } \\
\text { The Central Trust Company of Cincinnati } \\
\text { The Union Commerce Bank of Cleveland }\end{array}$ & $\begin{array}{r}11 \\
26 \\
8 \\
14 \\
12\end{array}$ & \\
\hline The 10 Largest Banks in Ohio & 223 & 37.29 \\
\hline $\begin{array}{l}\text { The First National Bank of Akron } \\
\text { The Winters National Bank of Dayton } \\
\text { The Huntington National Bank of Columbus } \\
\text { The Provident Bank of Cincinnati } \\
\text { The City National Bank and Trust } \\
\text { Company of Columbus } \\
\text { The Dollar Savings and Trust Company } \\
\text { of Youngstown } \\
\text { The Ohio Citizens Trust Company of Toledo } \\
\text { The Firestone Bank of Akron } \\
\text { The National Bank of Toledo } \\
\text { The Dime Bank of Akron }\end{array}$ & $\begin{array}{r}14 \\
8 \\
1 \\
17 \\
6 \\
10 \\
6 \\
0 \\
9 \\
4\end{array}$ & \\
\hline The 20 Largest Banks in Ohio & 298 & 49.83 \\
\hline
\end{tabular}

Source: Number of Branches Operated by Member Banks and Nonmember Banks in Fourth Federal Reserve District, " Examination Department, Federal Reserve Bank of Cleveland, 1960. 
total branch offices in Ohio were under the control of the 20 leading banks.

The preceding analysis clearly demonstrates that the control of branch banking exercised by the major banks in Ohio was sharply reduced during the postwar period. This reduction in the control of branch banks took place despite the fact that the number of branch offices operated by the 20 largest banks in Ohlo Increased by 166 from 1945 to 1959.

B. The Number of Branch Banks in Operation in the Elght Metropolitan Counties in Ohio

The number of branch banks in operation in the el ght metropolitan counties in Ohio in 1945 and 1959 is presented in Table 31.

At the beginning of the postwar period the eloht metrofolftan counties accounted for 86.28 per cent of the total number of branch banks in Ohio. In that year the eight counties contained a total of 151 branch offices. In 1959 the metropolitan counties held a total of 369 branch banks; however, in that year these branch offices represented only 61.70 per cent of the total number in ohio.

In 1945 two of the metropolitan counties, Curahoga and Hamilton, had 123 branch offices which was equal to 70.28 per cent of all branch banks in ohio. In 1959 these two countles contained 223 branch banks, but this number accounted for only 36.95 per cent of the ohio total.

In 1945 Cuyahoga County had the largest number of branch banks of any of the 88 Ohio counties. In that year Cuyahoga County 
contained 70 branch banks or 40.00 per cent of all branch offices in the state. Fourteen years later Cuyahoga County remained the leading county with 142 branch offices, but this representec only 23.74 per cent of the total number of branch offices in Ohio.

It is evident that the most predominant characteristic in the pattern of branch banking in Ohio during the postwar period was greater diffusion of branch offices among the banks and trroughout the 88 counties in Ohio. The importance of major banks and metropolitan counties in branch banking underwent a significant decline during the 14 year perlod.

\section{Primary Causes of Increased Branch Banking}

Since bankers are businessmen, and, like all businessmen, the primary purpose in conducting a business operation is the maximazation of profit, it can be assumed that branch banks have been established as a result of the opportunities for profit. The principal objective of this section is to explain the primary reasons for the increased profits of branch banking since the end of world War IT.

\section{A. Retall Banking}

Gradually over the last 20 years commerclal banking has undergone a transformation from a so-called wholesale banking business in which the primary purpose of the bank was to serve the financial needs of business, to a retail banking business in which the role of 
TABLE 31

THE NUMHER AND PERCENTAGE OF BRANCH BANKS

IN THE OHIO METROPOLITAN CONNTIES

IN 1945 and 1959

\begin{tabular}{|c|c|c|c|c|}
\hline \multirow[b]{2}{*}{ County } & \multicolumn{2}{|r|}{1945} & \multicolumn{2}{|r|}{1959} \\
\hline & $\begin{array}{c}\text { Number of } \\
\text { Branch } \\
\text { Eanks }\end{array}$ & $\begin{array}{l}\text { Percentage of } \\
\text { the Total } \\
\text { Branch Banks } \\
\text { In Ohlo }\end{array}$ & $\begin{array}{l}\text { Number of } \\
\text { Eranch } \\
\text { Panks }\end{array}$ & $\begin{array}{c}\text { Percentage of } \\
\text { the Total } \\
\text { Branch Banks } \\
\text { in Ohio }\end{array}$ \\
\hline Cuyahoga & 70 & 40.00 & 142 & 23.74 \\
\hline Frank1 in & 12 & 6.85 & 31 & 5.18 \\
\hline Hamilton & 53 & 30.28 & 79 & 13.21 \\
\hline Lucas & 5 & 2.85 & 31 & 5.18 \\
\hline Mahoning & 3 & 1.71 & 22 & 3.67 \\
\hline Montgomery & 4 & 2.28 & 21 & 3.51 \\
\hline Stark & 2 & 1.14 & 21 & 3.51 \\
\hline Sumet & 2 & 1.14 & 22 & 3.67 \\
\hline Total & 151 & 86.28 & 369 & 61.70 \\
\hline
\end{tabular}

Source: Number of Branches Operated by Member Banks and Nonmember Banks in Fourth Federal District," Examination Department, Federal Reserve Bank of Cleveland, 1960, and Polk's Bankers Encyclopedla, March, 1946. 
the bank is to serve not only the credit needs of business but the general public as well. As one banker stated it:

Just as in the production and distribution industries, banking is now on a mass basis. Mass production and seliling have inevitably brought about sharp change in the distribution of credit. The personal, consumer, and installment loans have become an essential factor in the mass production and di stribution of goods. 1

I Statement by Lee P. Miller, President of the Citizens Fidelity Bank and Trust Company, Loulsville, Kentucky, contained in U. S. Congress, House, Antitrust Subcommittee of the Committee on the Judiciary, Hearings, Premerger Notification, 85th Cong., 1st Sess., 1957, p. 245 .

Retall banking calls for banking at the community level, and If a bank is to engage in retail banking successfully, it must establish offices which are convenient for its customers. The bank customers, primarily the middle-income group, have tended to move to the suburbs and this, in turn, has dictated the need for the formation of branch offices in the outlying areas. ${ }^{2}$ Retail banking

${ }^{2}$ See, for example, statement of John J. McCloy, Chairman of the Chase Manhattan Bank of New York, contained in U. S. Congress, House, Antfrust Subcommittee of the Committee on the Judiciary, Hearings, Bank Mergers, 84th Cong., 1st Sess., 1955, p. 16.

also requires that 2 wide range of services be made avai lable to bank customers. This creates higher operating costs for the individual banks. Through branch operations, however, the banks are able to attract the large volume of deposits they need to support such services. 
The Comptroller of the Currency stated that consumer lending has been a factor of such importance in the expansion of branch banking that any major contraction in the amount of such business could lead to the eventual abandonment of many brench banks. ${ }^{3}$

${ }^{3}$ Annual Report Comptroller of the Currency, 1955, p. 10.

B. Population and Pusiness Movements to the Suburbs

Other significant forces in the formation of branch tanks since the end of horld war II are the formation of shopping centers in non-congested suburban areas and the decentralization of industry which has placed an increasing proportion of the new industrial sites on the periphery of metropolitan areas. In order to retain not only individual accounts but also business accounts many banks have found it necessary to follow their customers to the suburbs. 4

4 "The Growth of Branch Banking," New England Business Review of the Federal Reserve Bank of Boston, Apri1, 1959, p. 3.

The question has arisen as to whether or not the banking needs of the suburban consumers and business customers are best served by the establishment of new unft banks or through the extension of operations of existing banks. It is generally recognized, however, that the branch banking offices provide a more economical means of serving the banking needs of these areas. 
There are many suburban communities which generate substantial demand for personal and real estate loans but relatively small deposit volume. A unit bank in such a community would be unable to satisfy filly the banking needs of this community because it would not have sufficient funds to meet the demand for loans unless it invited larger banks to particlpate in its loans. On the other hand in communities with large deposit volume but inadequate loan demand, a unit bank might experlence difficulty in making the most efficlent use of its available funds. A branch bank, however, could find such offices profitable. 5

$$
\text { IIbid., p. } 4 \text {. }
$$

A report by the Federal Denosit Insurance Corporation provides three other reasons for the establishment of branch banis in the suburban areas rather than organizing new unit banks. First, there is more difficulty in obtaining permission from the regulatory officials to operate a new bank as opposed to a branch bank. Second, existing bants are usually abie and desirous of opening branch offices in these areas before the community provides enough banking business to support an independent bank. Third, many of the residents of the outlying areas prefer to deal with banks which are larg̣er and better known throughout the region. 6

6 Federal Deposit Insurance Corporation, Changes in the Number of Banking Offices, 1859-1958, and in Banking Concentration, 1921-1958, p. 33.

The movement out of the city by industry has been prompted by the desire to set up extensive one-level production lines and provide ample room for future expansion. The increased use of truck 
transportation as a means of moving goods to market has also made it possible for industry to move to the outlying areas. The banking needs of these organizations, however, are best served through the branch operations of larger banks rather than the creation of independent suburban banks.?

7 House Select Comittee on Small Eusiness, Banking Concentration and Small Business, 86th Cong., 2nd Sess., p. 48 .

The growtr. of the suburban areas in ohio, like the rest of the country, has also greatly exceeded that of the major cities since the end of world war II. 8

8

Ohfo Population Growth and Distribution, p. 21.

\section{Operating Costs}

In discissions with bank officers in Oh:o and officers in the various regulatory agencies it became evident that little concrete evidence concerning the costs of operation of branch banis as opposed to unit banks is avallable. Most bankers interviewed stated that they employ a centralized accounting system, and any allocation of costs to branches is on a "rule of thumb" basis.

In 1958 a study of branch bank operating costs in New England was made by Paul Horvitz with the aid of the Federal Reserve Bank of 
Eoston. This study was handicapped by a lack of sufficient information; however, $r$. Horvitz concluled his study with the following statement:

When a very small banking office is concerned (say one or two million dollars of deposits), it cannot be operated any cheaper as a branch than as a unit bank. . . . It is when bank offlces with a deposit volume of three to five millton dollars or more are involved that savings in branch operation become possible. Even in the case of these larger branches there is some amblgulty as to the possible savings of branch operations. In the majority of cases, the branch is gperated with a considerable savings of direct costs."

$9_{\text {Horvitz, pp. 127-128. }}$

The most cogent argument presented for the lower costs that branch banking can provide is based upon the need for a mass market in banking in order to efficiently tap the growing demand for consumer credit, acivertising in mass media, diversification of risk, and the opportunity to employ automation. It is aroued by many banking experts that to compete successfully in the mass market an extensive branch banking policy must be acopted. 10

$10_{\text {The Triple Banking System, }}$ (New York: M. A. Schapiro and
Company, Incorporated, 1956), p. L. Normally, the services offered by a large metropolitan bank are also available to customers of the branch offices, but in most 
cases a small independent bank would be unable to offer these services as a result of the prohibitive cost. 11

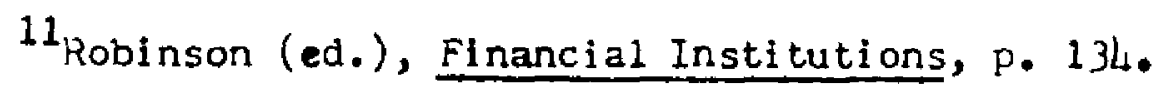

\section{Bank Management.}

The difficulty which banks have experienced in attracting competent management during the postwar period has served as still another factor which has favored the creation of branch banks as opposed to unit banks.

In a larger branch system the management may be more highly paid, therefore, attracting more capable personnel at the top levels. The branch managers need not be trained in all phases of bank management since many of the more technical and speciallzed aspects of banking are centralized at the head office. 12

\section{Alhadeff, Monopoly and Competition in Banking, p. 105.}

In addition to the economies resulting from the centralization of management in the branch system, the branch personnel are able to call upon the speciallsts in the central office for ald or information in various problems. This, in turn, provides the community which the branch bank serves with a higher quality banking service than a smaller unlt bank could afford. 
IV. Bank Supervision and Branch Banking in Ohio

The laws concerning the establishment of branch banks have been of paramount importance in determining the extent and pattern of branch banking in the United States. ${ }^{13}$

13 For a history of the legislation and development of branch banking in the United States see John M. Chapman and Ray $B$. Westerfield, Branch Banking (New York, N.Y.: Harper and 3rothers, Publi shers, 1942).

The regulation of branch banking in Ohio is provided for in both federal law and Ohio law. Eoth the federal government and the state government have the authority to permit the establi shment of branch banks in Ohio. There are four separate regulatory anencies which are active in the sunervision of branch banking in Ohio: the Comptroller of the Currency, the Ohio Superintendent of Banks, the Federal Reserve System, and the Federal Deposit Insurance Corporatlon. All banks in Ohio which operate under a natfonal bank charter must obtain permission from the Comptroller of the Currency before they may establish a branch bank. ${ }^{14}$ The state chartered banks in onio

14

Federal Code, Annotated, Title 12, sec. 36.

must receive the permission of the Ohio Superintencient of Banks before opening a branch bank, and in addition they may be compelled to obtain 
permission from one of two federal bank regulatory agencies. ${ }^{15}$ The

\section{${ }^{15}$ Banking Laws of Ohio, Annotated, 1103.09.}

state chartered banks in Ohio which are members of the Federal

Reserve System must obtain authorization from the Federal Reserve Board of Covernors before operating a branch office, and the nonmember state banks which belong to the Federal Deposit Insurance Corporation must receive approval from this agency before branch operations can be undertaken. ${ }^{16}$ Neither the Federal Reserve System 16 Federal Code, Annotated, Title 12, sec. 1828.

nor the Federal Deposit Insurance Corporation will consider the branch application of a state bank, however, before the Ohio Superintendent of Banis has given approval.

In examining the application for a branch office both state and federal agencies attempt to determine whether or not additional banking facilities are needed in the particular locality; if there is sufficient prospective business to justify the establishment of a branch; and whether or not an unnecessary duplication of banking facilities would result. ${ }^{17}$

17

Interview with the Ohio Superintendent of Banks, March 24 , 1961. Intervi ew with Mr. Paul Stetzelberger, Vice President, The Federal Reserve Bank of Cleveland, January 31, 1961. Interview with Mr. Gilbert E. Mounts, Supervising Examiner, District Four, Federa1 Deposit Insurance Corporation, February 3, 1961. 
Both state and federal law place two basic types of limitations on the formation of branch offices by the banks under their jurisdiction: geographical 1 imitations and minimum capital requirements.

\section{A. Teographical Limitations}

1. Ohio Law

The state law in Ohio as early as 1919 placed limitations on the distance from its main office which a state chartered bank could operate a branch office. A law passed on April 4, 1919 limited the operation of branch banking by state banks in the following manner:

No branch bank shall be establi shed until the consent and the approval of the superintendent of banks has been first obtained, and no bank shail establish a branch bank in any place other than that designated in its articles of incorporation, except in a clty or village contiguous thereto. $18^{\circ}$

18 Ohio, General Code, Annotated (Pace 1926), Section 710-73.

In 1931, however, the Ohio law was amended in order to provide greater opportunity for branch banking. The amendment resulted in the following change:

No branch bank shall be established unti 1 the consent and the approval of the superintendent of banks has been first obtalned, and no bank shall operate a branch bank in any place other than that designated in its articles of incorporation except in a city or village contiguous thereto, or in other parts of the county or counties in which the municipality contalning the main bank is located.19

${ }^{19}$ Laws of Onio, $710-73 ; 114 \times 109$ 
Again in 1935 the Ohio law was amended to further liberalize branch banking activity; however, since 1935 no further changes have been made. The present law in Ohio concerning the operation of branch banks permits the following:

No branch shall be established until the consent of the superintendent of banks has been obtained, and no bank shall establish a branch bank in any place other than that designated in Its articles of incorporation, except in a municipal corporation contiguous to such designated place or in other parts of the county in which the municipal corporation containing the main bank is located, provided any bank may maintain and operate as a branch banik a bank located in a county which is contiguous to the county in which the municipal corporation containing the main bank is located, and which on Jamuary 1, 1935, and prior thereto, bore to the main bank the relationship of "afflliate" within the meaning of that term as 1 it is used ig "The Banking Act of $1933^{\prime \prime}$ and the amendments thereto. 20

${ }^{20}$ Qhio Banking Laws, Annotated, 1103.09.

In the Baniking Act of 1933 (Glass-Steagall Act) the term "affiliate" was defined as any organization which a commerciai benk either directly or indirectly controlled. The act also included as an "affiliate" any organization which has a majority of its directors or trustees also serving as directors of one bank, 21

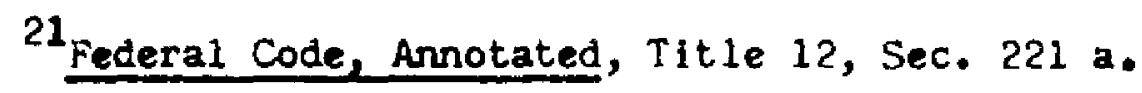

2. Federal Law

Until 1933 national banks in the United States were not permitted to operate branch banks outside of the city of the parent 
bank. 22 In the Banking Act of 1933 national banks became subject to

${ }^{22}$ Chapnan and Westerfleld, pp. 107-108.

the geographical linitations on branch banking imposed by the law of

the state in which they operate.

A national banking association may, with the approval of the Comptroller of the Currency, establish and operate new branches: (1) Within the linits of the city, town, or village in which said association is situated, if such establishment and operation are at the time expressly authorfzed by the law of the State in question; and (2) at any point within the State in which said association is situated, if such establishment and operation are at the time authorized, to State banks by the statute law of the State in question. ...23

${ }^{23}$ Federal Code, Annotated, Title 12, Sec. 36.

The federal law concerning the operation of branch banks by national banks has remalned the same since 1933. As a result, the geographical 1 imltations on branch banking in Ohio which are imposed by Ohio law apply to both national and state banks.

Table 53 (see Appendix) presents the 1 ocation of all branch banks in Ohio from 1945 to 1959 in relation to the location of the parent bank. In $1945,67.42$ per cent of all branch banks in Ohio were located in the same city as the parent bank, and 27.42 per cent of all branch offices were located in the same county as the parent bank but not the same city. The remaining 5.16 per cent of the branch bants in Ohio were located efther in counties contiguous to the 
county in which the parent bank was located, or on United States government property.

Py 1959 the proportion of all branch banks in Ohio located in the same city as the parent bank had been reduced to 52.41 per cent of the total, and the proportion of the total number of branch banks which were operating within the same county but outside of the clty in which the parent bank was located was 45.42 per cent. During the 14-year period there were 426 additional branch banks placed in operation in Ohio; and of that total 197 were located in the same city as the parent bank, 225 were opened in the same county but outside of the same city as the parent bank, and flue additional branch banks were established in a county contiguous to the county in which the parent bank was located.

\section{B. Capital Requirements}

\section{State Law}

In addition to Imposing geographical restrictions on the operation of branch banks, the Ohio law also requires that specific capital requirements be met by a state bank prior to the operation of a branch office.

No bank shall establish a branch as provided in section 1103.09 of the Revi sed Code unless each bank has, In addition to the minimum capital required by section 1103.10 of the Revised Code, sufficient capital equal to a minimum of thirty-five thousand dollars for each such branch to be establi shed in a village; to a minimum of fifty thousand dollars for each such branch to be established in a city the population of wich does not exceed twenty-five 
thousand; and to a mininum of one hundred thousand dollars for each such branch to be established in a city the population of which exceeds twenty-five thousand. 24

\section{$2 \mathrm{~h}_{\text {Banking Laws of Ohio, Annotated, }} 1103.11$.}

\section{Federal Law}

The national banks which desire to establish branch offices must also meet minimum capital requi rements which are 1 mposed by federal law and administered by the Comptroller of the Currency.

The aggregate capital of every national banking assoclation and its branches shall at no time be less than the aggregate mininum capital required by law for the establishaent of an equal number of national banking associations situated in the various places where such association and its branches are situated. 25

25 Federal Code, Annotated, Title 12, sec. 36.

This, in effect, neans that a national bank must provide an additional $\$ 50,000$ In capital for each branch which is operated in a town of 6,000 inhabltants or less, an additional $\$ 100,000$ of capital for each branch operated in communities with population ranging from 6,000 to 50,000 , and $\$ 200,000$ of additional capital for each branch operated in a comunity with a population in excess of 50,000 . $^{26}$ 
The state chartered banks which are members of the Federal Reserve System are required to meet the same capital requirements for estab1lshing a branch bank as national banks before the Federal Reserve Board of Governors will approve the operation of a branch bank. 27

27 Ibid., Title 12, Sec. 321.

An analysis of the differences in state and federal law concerning capital requirements for the establishment of a branch bank reveals that the national banks and state member banks in Ohio are required to meet more stringent capital requirements than the state nonmember banks in Chio.

Although the capital requirements for the formation of a branch bank differ in state and federal law, the most important impediment to the development of branch banking has been the geographical limitations placed on both state and national banks by Ohio law.

\section{Group and Chain Banking in Ohio}

Before proceeding with a discussion of chain and group banking in Ohio during the postwar period a distinction should be drawn between the two terms. Although both chain and group banks are simflar in the method of operation, nearly all experts in baniking recognize a distinction between the two methods of banking. Chain banking is an arrangement by which two or more banks--each of which retains $i$ ts 1 dentity, capital and personnel-are brought under common control by any 
device other than a holding company. Such control may be exercised in varying degree by majority stock. ownership or interlocking directorships and officerships. Group banking is a similar arrangement except that the Individual banks are controlled or owned directly or indi rectly by a holding company, or holding company affl liate. 28

$28_{\text {W. H. Steiner, E11 Sharpiro, and Ezra Solomon, Money and }}$
Banking (New York: Henry Holt and Company, 1958), P. 94.

Both the chain and group method of banking have been used as a means of circumventing the prohibitions against statewide branch banking.

Bank holding companies are most frequently found in those states where branching is prohibited, severely restricted, or Inadequately developed. 29

${ }^{29}$ Kurt F. Flexner, The Role of Savings and Loan Associations In the Banking Community of the State of New York (New York: The Savings As sociation League of New York, 1959), p. 19.

Many independent bankers view chain and group banking as evils which can only result in increased concentration in banking. 30

30 Statement of Ben BuBois, Secretary, Independent Rankers Association, contained in U. S. Congress, Senate, Committee on Banking and Currency, Hearings, Bank Holding Legislation, Part 3, 83 rd Cong., 2nd Sess., 1954, Pp. 723-726. 
There is no record of chain banking in Ohio during the postwar period. 31 on December 31, 1959, however, there were two registered 31 Interview with the Ohio Superintendent of Banks, March 24, 1961.

bank holding companies in operation in ohio. 32

${ }^{32}$ House Select Committee on Small Business, Banking Concentration and Small Business, 86th Cong., 2nd Sess., p. 39.

A. Group Banking in Ohio

During the entire postwar period there was a total of three bank holding companies in operation in Ohio; however, there were never more than two in operation at the sume time. 33

33 Interview with Paul Stetzelberger, Vice President, Federal Reserve Bank of Cleveland, January 31, 1961.

1. Morris Plan Corporation of America

From 1945 until 1954 the Morris Plan Corporation of America, a bank holding company, controlled The Bank of Ohio Company in Cleveland. In 1954 the holding company sold 1 ts interest in The Bank of Ohio Company to the Society for Savings in Cleveland which, in 
turn, liquidated The Bank of Ohio Company and distributed the proceeds to its depositors. 34

$34_{\text {Palmer T. Hogenson, The Economics of Group Banking }}$
(Washington, D.C.: Public Affairs Press, 1955), p. 19L.

\section{The Springfield Savings Society}

The Springfield Savings Society was the largest of the two mutual savings banks in Ohio in 1959 and, in addition, the organization controlled two commercial banks operating in Clark County.

In 1950 the Springfield Savings Society obtained permission from the Ohio Superintendent of banks to accuire the controlling interest in The F1rst State Bank of South Charleston, and in 1956, The Savings Society Commercial Bank was formed by the management of the mutual savings bank. 35 Immediately after the formation of The

35 Interview with Mr. Donald Wiegel, President, The Springfield Savings Society, March 21, 1961.

Savings Society Commerclal Bank in 1956 the management of the Springfield Savings Soclety was informed by the Federal Reserve Board of Governors that the formation of the second bank qualified the Springfield Savings Society as a bank holding company, and they were required to register and submit to regulation by the Federal Reserve Board of Governors. 36 36 Ib1d. 
The Springfleld Savings Soctety was not formed for the purpose of circumventing Ohio branch banking law, since all of the banks affillated with this particular holding company are located within Clark County. In 1959 the deposits of the three banks in the group totaled $\$ 33,004,000$, which was equal to 31.43 per cent of the total bank deposits in Clark County. ${ }^{37}$

\section{$37_{\text {American Bank Di rectory, }} 1960$, pp. 2035-2036.}

It is noteworthy that in 1959 the Springfield Savings Soclety started construction of a new buflding which will house both the mutual savings bank and The Savings Sockety Commercial Bank. This will result in the only joint operation of a mutual savings bank and a comercial bank of its kind in the United States. In addition, the Springfield Savings Society is the only mutual savings bank in the United States which also qualifies as a registered bank holding company. 38

${ }^{38}$ Interview with Mr. Donald Wiegel, March 21, 1961.

\section{The Bancohio Corporation}

The Bancohio Corporation in Columbus is the oldest and the largest bank holding company in Ohio. The organization was incorporated in Ohlo in 1929, and at the time of incorporation the group was 
composed of two commerclal banks. Bancohio Corporation has never maintained any affiliates outside of the state of onio.39

39 Interview with Mr. Henry Honrath, Comptroller, Bancohio Corporation, March 13, 1961.

Tables 54 and 55 (see Appendix) present the total number of banks which were affiliated with the Bancohio Corporation in 1945 and 1959. In addition, the total resources and the number of branches of each affillate are presented for the same dates.

In 1945 the 19 banks afflilated with the Bancohio Corporation were composed of 14 national banks and five state banks, and these 19 banks operated a total of 31 banking offices. The total assets of the 19 banks equalled 4.34 per cent of all bank assets in Ohio in 1945. The Ohio National Bank was the largest among the 19 affiliates, and the assets of The Ohio National Bank represented 60.87 per cent of the combined total assets of the Bancohio affiliates in 1945. At the beginning of the postwar perfod the 19 afflilated banks were operating in 18 ohio counties. The counties in whlch these banks were operating were located in central and southern Ohio. Franklin County, in 1945, contained three Bancohio affiliates, and these three institutions accounted for 42.71 per cent of all bank assets in Franklin County. 40

\section{Po1k's Bankers Encyclopedia, March 1946.}


The Ohlo National Bank was the only affiliate of the Bancohio Corporation that operated any branch offices in 1945. Including the 12 branch offices of The Ohio National Bank, 15 of the 31 banking offices controlled by the Bancohio Corporation were located in Frankiln County at the beginning of the postwar perfod. In 1945 only two of the 19 banks affiliated with the Banconio Corporation were not wholly-owned by the holding company. The Bancohio Corporation owned 99.27 per cent of the outstanding stock of The National Bank of Portsmouth and 99.00 per cent of the outstanding stock of The First National Bank in Chilif cothe. 41

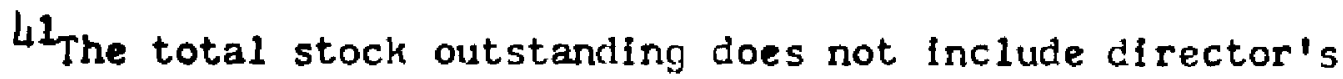
qualifying shares. Moody's Manual of Investments, 1946, p. 597.

In 1959 the Bancohto Corporation had a total of 22 affilfated banks and 51 banking offlces under its control. The banks were composed of 16 national banks and slx state banks. The total assets of the 22 affillated banks were equal to 5.93 per cent of the total bank assets in Ohto in 1959. The Ohlo Natfonal Bank remained the largest bank in the group w1th assets equal to 62.24 per cent of the total assets of the entire group.

The Bancohio Corporation had affiliates in 20 counties in central and southern Ohio in 1959. Two of the afflilates in Frank1 in County in 1945 were absorbed Into The Ohio National Bank during the postwar period, and two new affillates were acquired in Frank1In County during the same period. In $1959,57.78$ per cent of all bank assets 
in Franklin County were held by the three Bancohio affiliates operating in the county. 42

\section{Polk's Bankers' Encyclopedia, 1960.}

A total of elght of the Bancohio affiliates were operating branch offices in 1959; however, of the 29 branch banks in operation 22 were under the control of the three affllated banks in Franklin County. As a result of the concentration of branch banks in Frank1in County, 25 of the 51 banking offices of the Bancohio Corporation were located in Franklin County in 1959.43

43 For a discussion of the concentration of banking exercised by the Bancohio Corporation in Franklin County, see Federal Reserve Bulletin, April 1961, pp. 412-415.

In 1959 the Bancohio Corporation owned 100 per cent of the outstanding stock of all but five of the affillated banks. The percentage of the outstanding stock of these five banks held by the Banconio Corporation ranged from 83.0 per cent to 99.27 per cent. 44

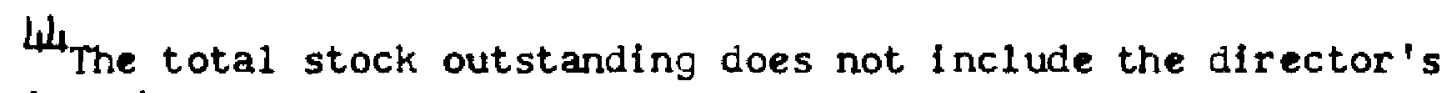
qualifying shares. Moody's Manual of Investments, 1960 , p. 681.

It is evident from the scope of operation of the Banconio Corporation during the postwar period that group baniking provides a means of circumventing the ohlo laws pertaining to the geographical restrictions on the operation of branch banks. Although the Bancohio 
Corporation increased the proportion of total bank resources which it controlled in Ohio during the postwar period, this expansion could hardly be judged as a major force toward bank concentration in Ohio. On a regional or county basis, however, the Bancohio Corporation exercised a significant degree of concentration during the subject period as evidenced by the proportion of total resources controlled by Bancohio in Franklin County in 1945 and 1959.

\section{B. Regulation of Croup Banking in Ohio}

1. State Law

Although bank holding companies have operated in Ohio since 1929, the Chio banking law makes no mention of group banking.

\section{Federal Law}

The primary reason for the lack of state regulation of group banking is the interstate nature of many group banking systems. The opponente of group banking, therefore, have tried to encourage the passage of federal laws to restrict group banking rather than attempting to persuade the varlous state legislatures to pass laws prohibiting group banking in their respective states.

Congress first passed laws regulating holding companies in 1933. 45 The Banking Act of 1933 required that all national banking

45 House Select Committee on Small Business, Banking Concentration and Small Business, 86th Cong., 2nd Sess., p. 39. 
associations obtain three reports annually from their holding company affiliates and submit them to the Comptroller of the Currency along with any other information the Comptroller requested concerning the relationship between the holding company and the national bank. The bank holding compantes were deprived of the right of voting the stock which they held in member banks unless a voting permit had been granted by the Federal Reserve Board of Governors. The Board of Governors was directed to determine the financial condition of the applicant and the probable effects of the holding company upon competition in banking before issuing a voting permit. In addition, holding companies were required to divorce themselves from control of securities and investment companies, to agree to hold a certain percentage of marketable assets, submit detailed financial reports to the Board of Governors, and recetve bank examiners. 46

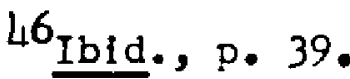

The 1933 legislation was found, however, to be an inadecuate method of regulating bank holding companies. There were several means which bank holding companies utilized to avoid regulation. Some holding companies had affliates wh thdraw membership from the Federal Reserve System in order to avoid having to acquire a voting permit from the Board of Governors. The law stated that a bank holdIng company was one which owned or controlled 50 per cent of the stock of one or more member banks. As a result, many holding companies were able to control affiliates with less than 50 per cent 
of the outstanding stock. Others were able to retain control over majority owned banks without voting their stock. 47

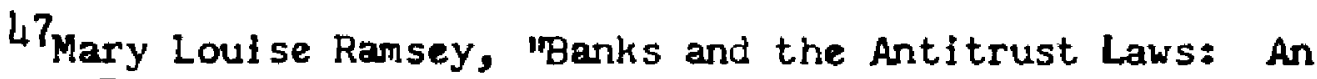
Unresolved Problem," American Bar Association Journal, June, 1951, F. L27.

Soon after the passage of the 1933 law there was a widespread cemand for more adequate legfslation to control group banking; however, it was not unti 1956 that Congress passed legislation to strengthen the 1933 act.

In 1938, the President, in a special message to the Congress, urged legislation which, in effect, would have resulted in the dissolution of bank holding companies. After 18 years of controversy and many pages of testimony, Congress decided upon regulation, not abolition. Thus, under the new law, the formation and growth of bapk holding companies are controlled but not prohibited. 48

48 The Triple Banking System, p. 25.

The Bank Holding Company Act of 1956 (Public Law 511) did not replace the 1933 legislation but reinforced the earlier legislation. The 1956 law defined a bank holding company more strictly by providing that a bank holding company is any organization that holds 25 per cent of the stock of two or more banks, controls in any manner the election of a majority of the directors of two or more 
banks, or where 25 per cent or more of the voting shares of each of two or more banks is held in trust. 49

${ }^{49}$ Federal Code, Annotated, Title 12, sec. 1841.

Under the 1956 Act the Federal Reserve Board of Governors has the right to approve or prohibit accuisitions which would convert a company into a bank holding company or the acquisition of one bank holding company by another. In addition, any bank holding company which desires to make an intrastate acouisition must submit an application to the Board of fovernors which, in turn, directs the application to the Comptroller of the Currency if a national bank is involved, or to the Superintendent of Banks if it is a state bank. The Comptroller of the Currency or the Superintendent of Banks must approve the acquisition before the Board of Governors will consider the petition. The law states clearly what factors the Board of Governors should consider in reaching their decision concerning the approval or disapproval of the acquisition. 50

50 Ibid., Title 12, sec. 1842 .

The 1956 law also flaced strict limitations on the acquisition of a bank located outside of the state in which the bank holding company maintains its principal office and conducts its operations. The 1 aw requires that before a holding company may acquile a bank in another state the statute law of the state in which the bank is 
located must specifically provide for such a purchase. 51 It seems

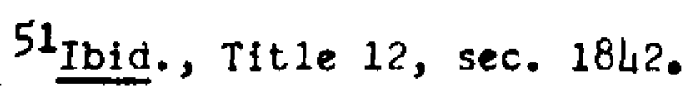

rather doubtful if many state lecislatures would be willing to pass legislation which would expressly permit a bank holding company located outside of the state to gain control of a bank located within the state.

The 1956 act further strengthened the earlier 1 aw by regulating any company which held 25 per cent of the stock or exercised control over two or more banks regardless of whether or not the two banks were member or nonmember banks, commercial banks or savings banks, and whether or not the stock of the banks was voted by the holding company. 52

52 Ibid., Title 12, sec. 1841.

The 1956 legislation also required that by no later than May 9, 1961 all bank holding companies had to divest themselves of ownership or control of any woting shares of any company which was not related to banking. The divestment requirements did not apply, however, to any company all of whose activities were of a financial, fiduciary, or insurance nature, and which the Board of Governors ruled to be closely related to the business of banking. 53

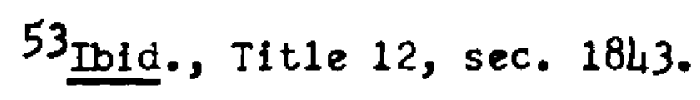


Finally, the law forbids a bank holcing company to borrow from a subsidiary bank, and a subsidiary bank is prohlbited from lending to any other subsidiary in the same group. 54

54 Ibid., Title 12 , sec. 1845

After the passage of the bill there were many bankers who held the opinion that the legislation had not been strong enough in regulating group banking activities, and President Eisenhower stated at the time he signed the Act that he believed the legislation should be stronger. 55 All banking experts seem to agree, however,

55 John Donoghue, "The Spence-Robertscn Act," Burroughs Clearing House, June, 1956, p. 37.

that the new legislation provides a substantial improvement over what existed before 1956.

VI. Advantages and Di sadvantages of Group Banking with Particular Reference to the Bancohio Corporation

In an attempt to determine the advantages and dfsadvantages of group banking an extended interview was held with Mr. Henry Honrath, Comptroller, Bancohio Corporation, on March 13, 1961. At that time Mr. Honrath discussed the competitive advantages and dism advantages which Bancohio affillates have encountered as a result of operating within a group system, and the effect of group banking upon 
the respective communities in wilch the afflifates operate. The literature concerned with group banking supports the statements made by Mr. Honrath.

\section{A. Advantages of Group Banking}

\section{Bank Investments}

A group systea is in a position to offer greater diversification and specialization in investments than is an independent bank. The Bancohio organization provides centralized investment for cash and reserve management for all affiliated banks. This service provides a caliber of investment services that the competing independent banks could not afford to maintain. Dafly contact is maintained with the money market by the Bancohio investment department, and as a result the profitability of the afflliated banks has been improved.

\section{Specialization in Management}

An independent unit bank, unless it is large, is unable to afford the services of a speciallzed staff. The Bancohto Corporation has developed and trained a staff which is capable of preparing tax returns for the affiliated banks, studying and recommending simplifications in accounting methods and forms, interpreting new banking regulations and legivlation, providing statistlcal and analytical data necessary for sound bank management, and providing 
information and suidance with respect to additions, remodeling, and improvements in physical facilities. 56

56 See statements of Bancohio Corporation contained in $\mathrm{U} . \mathrm{S}$. Congress, Senate, Committee on Banking and Currency, Hearings, Contro1 of Bank Holding Companies, 8hth Cong., 1st Sess., 1955, pp. 227-230.

\section{Examinations}

Although all banks in Ohio are examined by elther a federal or state regulatory agency, or both, only the larger banks can afford to maintain an internal auditing staff to make current investigations between the perlodic official examinations. The Bancohio Corporation, like other group systems, periodically examines each affiliate to assure that proper management is maintained. 57

$$
57_{\text {Hogenson, p. } 140 .}
$$

\section{Cost reduction}

The group banking system offers the opportunity of reducing operating costs through the centralized purchasing of equipment and supplies. The Banconto organization is able to reduce the operating costs of affiliated banks through the centralized purchasing of insurance, equipment, and supplies. Bancohio has also adopted a policy of centralized architecture which, according to Mr. Honrath, has materlally reduced bullding costs. All advertising of the Bancohio Corporation affiliates is centralized in order to reduce the cost of planning, layout and media. 


\section{Bank Services}

The banks affillated with the group system are often able to provide services to the community that competing independent banks are unable to afford. Many of the affiliates of the Bancohio Corporation are able to offer trust services to their respective communities through their affiliation with The Ohio Nation 1 Bank without encountering the cost of operating a trust department within their own banks. The banks in direct competition with the group system are often unable to absorb the cost of such additional services and, therefore, face a competitive di sadvantage.

\section{Personnel}

Group banking provides several advantages in the attraction and training of personnel. First, the opportunities for promotion are more numerous since each affillated bank has 1 ts own president and officers. Secondly, promotion opportunities are not limited to one bank but all banks within the groups. Third, group banking usually provides a large enough operation to enable the organization to undertake formal trainfing programs, retirement plans, and stock ownership programs for employees. 58

$$
{ }^{58} \text { Nadler and Bogen, The Bank Holding Company, pp. 32-33. }
$$

\section{Larger Lines of Credit}

If an afflliated bank receives a loan application which it is unable to grant due to lack of sufficient funds or loan limitations, 
another affiliate may be called upon to particlpate in the loan. An Independent bank, however, would either be forced to turn down the loan application or ask another independent bank to participate in the loan thereby surrendering a portion of the profit.

The Ohio National Bank often participates in loans with other affiliates of the Bancohlo Corporation. There is also cooperation among the Bancohio affiliates in the sale of municipal bonds and in the short-term financing of municipal and county governments. 59

\section{$59^{\text {Ibid., p. } 28 .}$}

\section{Decentralization}

Another primary advantage of group banking is the local character of each of its affliates. In a group each unit is managed by its own directors, who usually represent local interests and better understand local problems. The decentralization of management tends to promote operating efficiency and keener competition than a broad system of branch banks might provide. 60

60 Lent, p. 20.

In the Bancohio Corporation none of the directors or offlcers of the holding company serve as a director or an officer of an affillate. The officers and directors of each afflliated bank are citizens of the communties in which the banks are located. Mr. Honrath stated that as a result of this policy of decentralization 
many of the customers of the affiliated banks are unaware of the fact that their respective banks are part of a group system.

\section{Capital Needs}

The common stock of a bank holding company might prove to be more attractive to a potential stockholder than the common stock of an independent bank che to the marketability and the diversification present in the holding company stock. Professors Nadler and Bogen point out that no class of securities of comparable size has as limited marketability as commercial bank stocks. ${ }^{61} \mathrm{Mr}$. Honrath stated that

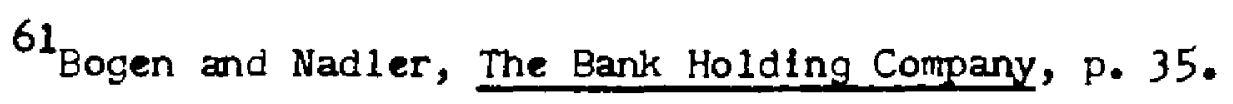

the stock of the Bancohio Corporation enjoys a much larger market than any of the stocks of the affliated banks before they entered into the holding company.

The diversification of banks represented by a holding company also attracts stockholders who might otherwise not desire to hold the common stock of an independent bank. As a result of the wider market for holding company stock, the capital structure of the individual banks may be expanded more easily and at a lower cost.

\section{B. Disadvantages of Group Banking}

1. Contrary to the Spirit of the Banking Law

There $c$ an be little argument that the operation of a bank holding company in Ohlo serves as a conventent means of circumventing 
the county line 1 imftations on branch bank operations. Through the holding company device individual banks become reglonal branches of the dominant or key bank in the group.

The primary factor in [bank holding companies7 their creation has been the search for a way to circumvent laws restricting the establishment of branches. If bank holding companies are 11 mited to the same geographical areas as are applied to branches, they are found to disappear. 62

62

F1exner, p. 23.

If the Ohio legislature and Ohio Superintendent of Banks are of the opinion that permitting the operation of branch banks outside of the county in which the parent bank is located is undesirable, then it would seem consistent to place the same limitations upon bank holding companies in Ohio.

2. Community Desire for an Independent Bank

There is still a strong desire for an independent and locally owned bank in many communities large enough to support a bank. As a result, the group banks are often placed at a disadvantage in attemptIng to compete with an independent bank.

Mr. Honrath stated that The First National Bank of Delaware, which is an affiliate of Bancohio, had recently received increased competition resulting from The Delaware County Bank radio and newspaper advertising which stated that inhabitants of Delaware should bank with a locally owned institution instead of a bank owned by nonresidents. 
The president of a bank in Steubenville reported that he had recently been approached by leading cftizens of Cadiz who hoped to persuade him to help organize a new bank in Cadiz in order to provide a locally owned bank to compete with the Eancohio affiliate which is the only bank in the community. It was the opinion of the citizens that their banking needs were not being properly met because of "absentee ownership." 63

${ }^{63}$ Interview with Mr. Charles L. Long, President, The First National Bank and Trust Company in Steubenvi1le, March 27, 1961.

\section{Loss of Local Responsibility}

Banking experts point out that although a local board of directors is nominally in charge of each of the banks in the group, they handle only routine operational matters, and the general policy making is retained by the officers of the holding company. The objection to this arrangement is that much of the responsiveness to local banking needs is lost. 64

$$
64,64 \text { Hogenson, p. } 145 .
$$

\section{Summary}

The pattern of growth in branch banking in Ghio during the postwar period resulted in a reduction in the concentration of branch banks among the larger banks and in the metropolitan counties in Ohio. In addition, a sioniffcantly larger proportion of all banks 
in Ohio were operating branch offices in 1959 than at the beginning of the postwar period. Turing the subject period the total number of banks in Ohio operating branch facilities was also more evenly distributed between national and state banks.

The rapid growtr of branch banking in ohio is a result of the change in the structure of the banking market, the shift of population and inclustry away from the cities to the outlying suburban areas, and the economies of operation provided through branch operation. The branch of an existing bank has proven, in many cases, to be a more efficient and desirable method of meeting the denand for additional banking offices than the formation of a new independent bank.

The Ohio law and federal law relating to the formation of branch banks has remained essentially unchanged during the postwar period. The two primary methods by which both ohio and federal law attempt to limit the expansion of branch banking are the geocraphical and $c \equiv$ Fital restrictions.

The most important of the two legal restrictions is the geographical limitation. Ohio law limits branch banking to the same county in which the parent bank is located with one minor exception. The federal law provides that all national banks are subject to the geographical restrictions on branch banking imposed by the 1 aw of the state in which they operate.

Ohio and federal law differ concerning the additional amount of capital that must be provided before a branch bank may be operated. 
The federal law requires a larger amount of capital per branch for national banks and state member banks than does the Ohio law which applies to state chartered nonmember banks.

The bank holding company serves as a convenient device for circumventing the geographical restrictions on branch banking imposed by Ohio law. Ohio law is silent on the operation of bank holding companies, and federal law permits the operation of statewide, and in some instances, interstate bank holding conpanies.

During the subject period there were three bank holding companies in operation in Ohio, and in 1959 two remained in operation. The largest of the bank holiing companies in Ohio is the Bancohio Corporation which, in 1959 , operated in 20 counties in central and soithern Ohlo and held 5.93 per cent of the total bank assets in Ohio.

The primary acivantage of group bankino is the abllity to avold compliance with the Ohio law on county-wide branch banking. Froup banking aiso offers the opportunity for bank management to acquitre increased specialization and economies of scale. One of the disadvantages of group banking is the desire of some communities to be served by independent, locally-owned banks. Another disadvantage stems from the inconsistency between Ohio branch bank law and the statewide operation of group banking. If the administrative and legislative officials in Ohio believe that a county-wide limitation on branch banking is needed to assure continued competition 
in banking, similar limitations should be placed on group banking. If, however, these officials elect to allow group banking in Ohio to continue on a stitewide basis then there would appear to be little justification in maintaining legislation which restricts branch banking to anythinç less than statewide operation. 


\section{CHAPTER V}

POSTWAR BANK CONHOLIDATTONS A:D :HARES IN OHIO

The purpose of this chapter is to examine the pattern of bank consolidations and mergers in ohio from 1945 to 1959 . In addition, the chapter considers the underlying causes of postwar bants combinations, anc the measures adopted by both federal and state government to control the combinations.

\section{Methods of Acquisition}

There are three primary methods by which one bank may absorb other banks: consolidation, merger, and purchase of assets. The official reports of regulatory agencies and banking law make little, if any, distinction between these methods. To be technically correct, however, a difference exists between the methods, and it should be recognized.

\section{A. Consolidation}

Writers on corporate finance describe a consolidation as the formation of a new corporation for the purpose of acquiring the assets and liabilities of two or more corporations which then pass out of existence as separate entities. The consolidation is usually carried out by having the newly formed corporation exchange shares 
of stock with the shareholders of the other corporations, and then the shares of the other corporations are cancelied upon dissolution of the issuer. ${ }^{1}$ Bank consolidations are also carried out by

1 Elvin F. Donalcison, Corporate Finance (New York: The Ronald Press Company, 1957), p. 689 .

organizing a new corporation and accuiring a new corporate charter, but normally a new bank charter is not acquired. Nearly all benk consolidations are carried out unier an existing bank charter of one of the absorbed banks, but if a new corporate charter is obtained banking authorities classify it as a consolication.?

2Interview with 'r. Paul Stetzelbercer, Vice President, Federal Reserve Bank of Cleveland, January 31, 1961.

\section{Merger}

A merger Is said to occur when two corporations are united in such a way that one is taken over $b$, the other, the absorbing corporation assumes all the assets and liabilities of the absorbed corporation. The absorbed corporation surrenders its charter and becomes an integral part of the absorbing institution which retains its original charter. ${ }^{3}$ In some instances a corporation will acquire ${ }^{3}$ Donaldson, p. 687. 
a stock interest in the corporations which it expects to absorb; however, banks are prohibited by both federal and state law from holding the stock of another bank. As a result, a bank merger is usually carried out on a basis whereby the stockholders of the absorbed bank exchange their shares for stock in the absorbing bani, and the absorbed bank stock is cancelled upon dissolution of the issuing corporation.

\section{Purchase of Assets}

Many banking authorities do not distinguish between a bank merger and a purchase of assets. In a purchase of assets the absorbing bank will assume the 1 iabilities (in total or in part) and purchase the assets (in total or in part) of the absorbed bank. The stoctholders of the absorbed bank receive the proceeds from the sale of their assets to the absorbing bank, plus any remaining assets of the absorbed bank, and the latter w11l then be dissolved.

In a purchase of assets the stockholiers of the absorbed bank may receive stock of the purchasing bani, or cash, or a combination of stock and cash. There are advantages in receiving stock of the absorbing bank rather than cash. If the assets are sold for cash, any profit arising will be treated as a capital gain, and a tax must be paid in the year in which the sale took place; whereas if stock is recelved for the assets, it can usually be carried out under. 
tax-free exchange, and the capital gains tax is not applicable until the stock is sold. 4

4 trithe Branch and Merger lovement in the Third Fecteral Reserve District," Business Review of the Federal Reserve Bank of Philadelphia, November, $195 \mathrm{~h}, \mathrm{p} .11$.

The purchase of assets method of acquisition has an advantage in that it is a more flexible method of combination. In a merger, the two banks are combined in total. Under a purchase of assets arrangement only a part of the assets and $1 \mathrm{i}$ abilities need be included. It occasionally happens that a bank $i$ interested in assuming oniy the savings deposit liabilities of another bank, or perhaps only the trust department. In some cases there is some portion of the absorbed bank's loan or inves'ment portfolio which the absorbing bank does not wish to assume. In cases such as these the purchase of assets is a preferable method of accuisition.

As was stated earlier, there is little distinction made between the meaning of a combination, merger, and a purchase of assets in the field of banking. These terms are used generally when referring to all types of combinations among banks. 5 In reporting

${ }^{5}$ Chapman, Concentration in Banking, p. 43.

the number of banks absorbed during the postwar period, regulatory agencies have not distinguished between the different methods of acquisition. The terms "consolidation" or "mergers," therefore, 
are used throughout the balance of this treatise to include all three methods of acquistion.

\section{Bank Consolidations and Mercers in Ohio}

A. The Number of Paniks Absorbed in Ohio

Ohio has been one of the leading states in the number of bank mergers that have taken place since the end of World har II. From 1950 to 1959 Ohio placed fourth behind Pennsy I vania, New York, and California in the number of banis absorbed through consolidation or merger. 6

6

Senate Committee on Banking and Currency, Regulation of Eank Mergers, 1959 , pp. 138-180; and House Comittee on Banking and Currency, Regulation of Bank Mergers, 1960 , pp. 20-23.

Table 32 presents the number of banks in thio that were absorbed by other banks during the postwar period. It is noteworthy that of the 106 banks which were absorbed by other banks in inio during the postwar period, 83 of the banks, or 78.30 per cent, were absorbed between 1952 and 1959. This indicates that the trend toward bank mergers in Ohio became stronger in the latter half of the postwar period. This observation is further supported by the fact that in the four-year period 1955 to 1959, a total of 56 banks in Ohio were absorbed, and in the year 1959, 18 banks in Ohio were absorbed which was the largest number in any single year of the entire postwar perfod. 
The pattern of bank mergers and consolidations in ohio during the postwar period closely paralleled the national pattero. During the 1h-year perlod which followed the end of World war II, 1,906 banks in the United States were absorbed, and approximately $6 t .98$ per cent of the combinations took place between 1952 and 1959.

7 House Committee on Banking and Currency, Regulation of Bank Mergers, 1960, p. 135.

of the 106 banks in Ohio absorbed from 1945 to 1959, state chartered banks accounted for 78 or 64.64 per cent of the total. This provides a partial explanation of the decline of state chartered banks as a proportion of all banks in Ohio during the same period. National banks, on the other hand, accounted for only $2^{p}$, or 26.41 per cent, of the total number of banks which were absorbed in ohio in the postwar period.

\section{B. The Size of the Banks Absorbed in Ohio During the Postwar Period}

Table 33 presents the number of banks in Ohio which were absorbed auring the postwar period classiffed according to the amount of assets.

It is evident from an analysis of Table 33 that the smaller banks in Ohio were the ones which were acquired during the postwar consolidation and merger movement. Of the total number of banks absorbed in Ohio during the subject period, 66.03 per cent had total 
TABLE 32

MUMBER OF BANKS IN OHIO ABSORPED

THROUGH CONSOLIDATION OR MERGER

1945-1959

\begin{tabular}{cccc}
\hline Year & $\begin{array}{c}\text { Al1 } \\
\text { Banks }\end{array}$ & $\begin{array}{c}\text { National } \\
\text { Banks }\end{array}$ & $\begin{array}{c}\text { State } \\
\text { Banks }\end{array}$ \\
\hline 1945 & 1 & 1 & 1 \\
1946 & 3 & 2 & 2 \\
1947 & 6 & 4 \\
1948 & 2 & & 2 \\
1949 & 4 & & 4 \\
1950 & 4 & 1 & 4 \\
1951 & 3 & 1 & 2 \\
1952 & 7 & 4 & 6 \\
1953 & 10 & 3 & 6 \\
1954 & 10 & 5 & 7 \\
1955 & 13 & & 8 \\
1956 & 8 & & 8 \\
1957 & 8 & & 8 \\
1958 & 9 & 5 & 12 \\
1959 & 18 & 6 & 77 \\
\hline Tota1 & 106 & 28 & \\
\hline
\end{tabular}

Source: Annual Report of the

Comptroller of the Currency, 1946-1960 and Annual Report of the Ohlo Division of Banks, 1946-1960. 
TABLE 33

ALL BANKS IN OHO AESORBED THROKFH CONSOLIDATION OR MERGER, CLASSIFIED ACCORDIMS TO AMOUNT OF ASSETS

1945-1959

\begin{tabular}{|c|c|c|c|c|c|c|c|c|}
\hline Year & $\begin{array}{l}\text { Less than } \\
\$ 1 \text { million }\end{array}$ & $\begin{array}{l}\$ 1 \text { to } 2 \\
\text { milition }\end{array}$ & $\begin{array}{l}\text { "2 to } 5 \\
\text { milition }\end{array}$ & $\begin{array}{l}\$ 5 \text { to } 10 \\
\text { million }\end{array}$ & $\begin{array}{l}\$ 10 \text { to } 25 \\
\text { million }\end{array}$ & $\begin{array}{l}\$ 25 \text { to } 50 \\
\text { millt on }\end{array}$ & $\begin{array}{l}\$ 50 \text { to } 100 \\
\text { millit on }\end{array}$ & $\begin{array}{c}\text { Over } \\
\$ 100 \mathrm{milli} \text { in }\end{array}$ \\
\hline $\begin{array}{l}19145 \\
1946 \\
1947 \\
1948 \\
19149\end{array}$ & 1 & $\begin{array}{l}1 \\
1 \\
2\end{array}$ & $\begin{array}{l}1 \\
3 \\
2\end{array}$ & $\begin{array}{l}1 \\
1\end{array}$ & 1 & & & \\
\hline $\begin{array}{l}1950 \\
1951 \\
1952 \\
1953 \\
1954\end{array}$ & $\begin{array}{l}2 \\
2\end{array}$ & $\begin{array}{l}1 \\
1 \\
3 \\
4\end{array}$ & $\begin{array}{l}2 \\
2 \\
1 \\
1\end{array}$ & $\begin{array}{l}1 \\
3\end{array}$ & $\begin{array}{l}1 \\
1 \\
2 \\
1\end{array}$ & $\begin{array}{l}2 \\
1\end{array}$ & 1 & \\
\hline $\begin{array}{l}1955 \\
1956 \\
1957 \\
1958 \\
1959\end{array}$ & $\begin{array}{l}1 \\
1 \\
1 \\
1\end{array}$ & $\begin{array}{l}3 \\
3 \\
1 \\
1 \\
5\end{array}$ & $\begin{array}{l}3 \\
4 \\
3 \\
4 \\
7\end{array}$ & $\begin{array}{l}2 \\
2 \\
1 \\
2\end{array}$ & $\begin{array}{l}3 \\
1 \\
4\end{array}$ & 1 & & 1 \\
\hline Total & 10 & 27 & 33 & 13 & 15 & 5 & 2 & 1 \\
\hline
\end{tabular}

Source: U. S. Congress, Senate Committee on Banking and Currency, Hearings, Regulation of Bank Mergers, 86th Cong., ist Sess., S. 1062 and U. S. Congress, House Commlttee on Banking and Qrrency, Hearings, Regulation of Pank Meroers, 86th Cong., and Sess., S. 1062. 
assets of less than $\$ 5 \mathrm{million}$, and 92.45 per cent of the absorbed banks had total assets of less than $\$ 25 \mathrm{ml} 11$ ion. The group which accounted for the largest number of absorbed banks was the group with assets ranging from $\$ 2$ to $\$ 5$ million.

The only bank to be absorbed during the postwar period with assets in excess of $\$ 10 \mathrm{mi} 11$ ion was a mutual savings bank rather than a commercial bant. The Society for Savings in Cleveland with total assets of $\$ 334,487,457$ was absorbed by The Society National Bank of Cleveland in 1958.8

\section{${ }^{8}$ Ibid., p. 25.}

C. The Size of Banks with Acruired Other Sanks in Ohio During the Postwar Period

Table 34 presents the number of banis in Ohio which acquired other banks through consolidation or merger during the postwar period.

In contrast to the many statements before Congressional committees concerning the dominance of the larger banks as acquiring banks in combinations during the postwar period, the larger banks in ohio did not account for the majorlty of the bank acquisitions during the subject. period. Table 34 reveals that the banks in ohio with assets of less than $\$ 50$ million accounted for 62.26 per cent of all the bank acquisitions in the postwar period, and the banks with 
TABLE 34

ALI ACOUIRIIG BANKS IN OHIO, CLASSIFIED ACCORDINF: TO THE AMOUN OF ASSETS, $1945-1959$

\begin{tabular}{|c|c|c|c|c|c|c|c|c|}
\hline Year & $\begin{array}{l}\text { Less than } \\
\$ 1 \text { million }\end{array}$ & $\begin{array}{l}\$ 1 \text { to } 2 \\
\text { million }\end{array}$ & $\begin{array}{l}\$ 2 \text { to } 5 \\
\text { milli on }\end{array}$ & $\begin{array}{l}\$ 5 \text { to } 10 \\
\text { million }\end{array}$ & $\begin{array}{l}\$ 10 \text { to } 25 \\
\text { million }\end{array}$ & $\begin{array}{l}825 \text { to } 50 \\
\text { million }\end{array}$ & $\begin{array}{l}\$ 50 \text { to } 100 \\
\text { million }\end{array}$ & $\begin{array}{c}\text { Over } \\
\$ 100 \mathrm{mill1} \text { on }\end{array}$ \\
\hline $\begin{array}{l}1945 \\
1946 \\
1947 \\
1948 \\
1949\end{array}$ & & & $\begin{array}{l}1 \\
3\end{array}$ & $\begin{array}{l}1 \\
1\end{array}$ & 1 & 1 & 2 & $\begin{array}{l}1 \\
1 \\
2 \\
1\end{array}$ \\
\hline $\begin{array}{l}1950 \\
1951 \\
1952 \\
1953 \\
1954\end{array}$ & 1 & 1 & $\begin{array}{l}2 \\
1\end{array}$ & $\begin{array}{l}1 \\
3\end{array}$ & $\begin{array}{l}1 \\
1 \\
1 \\
2 \\
1\end{array}$ & $\begin{array}{l}1 \\
2 \\
2\end{array}$ & 1 & $\begin{array}{l}2 \\
4 \\
3 \\
2\end{array}$ \\
\hline $\begin{array}{l}1955 \\
1956 \\
1957 \\
1958 \\
1959\end{array}$ & & & 1 & $\begin{array}{l}2 \\
4 \\
3 \\
4 \\
1\end{array}$ & $\begin{array}{l}4 \\
1 \\
8\end{array}$ & $\begin{array}{l}1 \\
1 \\
2 \\
1 \\
2\end{array}$ & $\begin{array}{l}1 \\
1 \\
1 \\
3\end{array}$ & $\begin{array}{l}4 \\
3 \\
2 \\
1 \\
4\end{array}$ \\
\hline Total & 1 & 1 & 9 & 22 & 20 & 13 & 9 & 31 \\
\hline
\end{tabular}

Source: Moody's Mamual of Investments, 1946-1960. 
assets ranging from $\$ 5$ to $\$ 25 \mathrm{~m} 111$ ion acquired 41.51 per cent of all the absorbed banks in Chio during the same period. The largest burks in Ohio, those with total assets in excess of $\$ 100 \mathrm{million}$, were responsible for only 29.24 per cent of the acquisition during the entire postwar period.

A comparison of Tables 33 and 34 shows that the basic pattern of bank consolidations and mergers in Ohio during the postwar perlod was one of small hanks being absorbed by primarily small and medium-sized banks. The largest class of hanks in ohio absorbed only 31 banks during the period, and the charge that the postwar Increase in consolidations and mergers resulted from an attempt by the largest banks to increase their share of the total banking rescurces is not valid as an explanation of the postwar bank consolidation and merger movement in Ohlo.

\section{IT. Factors Contributing to Bank Mergers and Consolldations During the Postwar Perlod}

The purpose of this section is to examine the primary causes of bank combinations during the period 1945 to 1959. Each bank combination has its own specific contributory causes; however, the officials of the federal and state bank regulatory agencies and other banking authorities have recognized some common causes which occur more frequently than others, and these are discussed in the following pages. 


\section{A. The Increase in Branch Banking}

The postwar increase in branch banking has proceeded along two main lines: the establishment of de novo branches, and the acquisition of existing banks and conversion of them into branches of the acruiring bank.

The establishment of branch offices by acguiring existing banis has several advantaces over the other method. When an existing bank is acquired and converted to a branch office, the acouiring bank benefits from the existing banier-customer loan relationstips, and the branch does not have to buile its deposits from zero. The problem of obtalning permission to estahlish a branch operation may also be facilitated by acquiring an existing bank.

Legal considerations also often impel branch bank expansion by acquisition rather than by de novo branches. A de novo branch must satisfy the regulator: authorities of the "need" for its existence, and that is not always easy when other banks already exist in the area. Moreover, it would be difficult to obtain authorization for as many de novo branches as could be obtained in a large, multibank merger. 9

${ }^{9}$ Charlotte P. Alhadeff and David A. Alhadeff, "Recent Fank Mergers," Quarter 1y Journal of Economics, November, 1955, p. 517.

A further advantace of acquiring a branch via the consolicam tion or merger route lies in the fact that the problem of providing personnel to staff the branch is automatically solved by retaining most of the old personnel. The postwar shortage of trained bank personnel, and the difficulty which banks have encountered in 
attracting capable employees acts as a further stimulus to acquiring branch offices by this method.

Even where legal and personnel problems are not obstacles to establishing a de novo branch, the comblnation method may prove more satisfactory where the construction costs are high and where the acquisition would eliminate some of the competition. In addition, the consolldation or merger method is "a better basis for estimating the future success of the branch which the operating experience of the existing banik provicies." 10

10 "The Bank Merger Movement," New England Business Review of the Federal Reserve Bank of Boston, Nay, 1950, p. 5 .

\section{B. Fallure to Attract Successor Manacement}

One of the most important reasons for bank combinations during the postwar feriod has been the inability of many banks to attract or the failure to train replacements for aging members of bank management.

Top management problems have been among the most important reasons. In many banks the advancing age of officers, and fallure to provide successor manacement, has resulted in mergers. In others, the managing owners have wished to retire from the banking business. 11

11 Annual Report of the Comptroller of the Currency, 1954, p. 9.

The Ohio Superintendent of Banks stated that the fallure to provide successor management was the primary cause of bank 
consolidations and mergers in ohio during the postwar period, and this statement was supported by Mr. Paul Stetzelberger of the Federal Reserve Bank of Cleveland. 12

${ }^{12}$ Interview with the Ohio Superintendent of Banks, March 24 , 1961, and interview with Mr. Paul Stetzelbercer, Vice-Presicent, Federal Reserve Bank of Cleveland, January 31, 1961.

A survey taken by the Federal Reserve Bank of Philadelphia revealed that bank supervisors considered the problem of successor management as the greatest weakness in present bank management. The survey further indf cated that management problems played a part in bringing about one-half of 66 bank mergers involved in the study. 13

13"The Branch and Merger Movement in the Third Federal Reserve District," Business Review of the Federal Reserve Benk of Philadelphia, January, 1955, p. 6.

The management problem has occurred most frequently among the smaller rural banks. The Ohio Superintenient of Banks pointed out that many of these banks fail to earn a large enough income to allow them to pay the salaries needed to attract desirable management, and in many cases even adequate salaries did not provice inducement enough to persuade younger men to reside outside of metropolitan areas and leave the employment of larger banks where the promotion possiblittes are more promising. 


\section{Financial Considerations}

The market for the stock of 'small banks is thin. Typically, there are few stockholders, and the ownership is heavily concentrated. The president of a small bank ginite often makes the market in the bank's stock. To sell his shares a stockholcer contacts the president of the small bank, who may be able to supply a buyer, but more often the seller's name is placed on a list to wait until someone places a bic. As a result, the stock of a small bank has little marketablity and usually sils below its book value. ${ }^{14}$

14 Eugene $H$. Lerner and Donald P. Jacobs, "Why i.e Need a Better Market for Bank Stocks, "Banking, September, 1960, p. 128.

Since the end of World war II many stockholders in small banks have been able to realize a fair price for their shares through a consolidation or merger with another bank. In testimony before the House Judiclary Comittee the Comptroller of the Currency stated the following as one rea on for the postwar increase in bank consolications and mergers.

Prices or terms have been of fered which the shareholders have found most attractive. These prices or terms have been equal to book value of the assets, and in many cases have been on a fair value basis plus a premium. This has been a particularly strong factor because the stock of

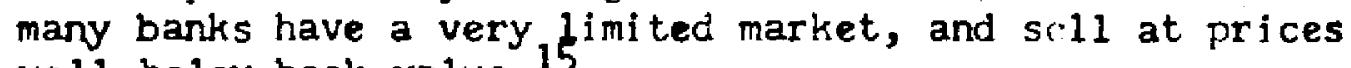
well below book value. 15

15 . S. Congress, House, Committee on the Judiciary, Hearings, Current Antitrust Problems, Part I, 86th Cong., 1st Sess., p. 462 . 
In determining the value of a bank in negotiating a consolication or merger some assets of the bank are often written up in order to reflect their real value. This practice often resilts in the payment of a premium above what the stockholders of the absorbed bank considered the book value of their stock. Probably the most frequent adjustment is the value of the bank buildings. Many banks carry the value of bank buildings at a conservatively low figure. Another adjustment may be in the value assicned to investments. Banks often carry investments at original cost which may be increased to conform with current market values. 16

16 "The Branch and Merger Movement in the Third Federal Reserve District," Business Review of the Federal Reserve Bank of Philadelrihia, November, $1954, \mathrm{p} .15$.

The amount of premium which may be paid above book value in a bank consolidation or merger is limited indirectly by the supervisory authorities. Because the bank supervisory authorfties discourace writing-up the value of assets, the acquirin bank will normally absorb the premium which it paid by relucing its surplus or undivided profits rather than capitalizing the premium on its books. Even then the supervisory authorities may refuse to approve such transactions, or may insist that the absorbing bank acquire additional capl tal. Thus, the desire for a premium above book value by stockholders of a small bank has in some instances resulted in the decision by bank management to scrap plans to absorb another bank. 
There would be even more mergers than there are today if many banks did not ask premiums ranging from 6 to 10 per cent of their deposits. To pay such a premium often would mean a period of ten years before the acouiring bank could earn it from employment of assets acquired.17

${ }^{17}$ Ed Tyng, "Bank Merging Today. . . No Job for Poys," Burroughs Clearing House, December, 1960, p. 47.

The stockholders of smaller banks have favored an exchange of stock with a larger bank as a means of acquisition. The securities of larger banks are usually traded in wider markets, more information on larger banks is published in financial manuals, bid and ask quotations for the stock of larger banks often appear in many of the urban newspapers, and, as a result the securities of the larger banks have better marketability. Lerner and jacobs stated that the marketability of the stock of the larger banks "has contributed to the fact that they sell at a hicher price earnings ratio than the smaller banks, and tyoically at a premium over book rather thar at a discount from book. ${ }^{18}$

18 Lerner and Jacobs, Banking, September, 196\%, p. 128.

\section{Loan Limitations}

Another specific problem which bank management has attempted to solve by consolidation or merger is the problem of loan limitations imposed by 1aw. Both federal and Ohio law $11 \mathrm{~m}$ t the maximum unsecured loan which a national or state bank can make to any non- 
governmental borrower to 10 per cent of the total capital, surplus, and undivided profit of the bank. ${ }^{19}$

\footnotetext{
${ }^{19}$ Federal Code Annotated, Title 12 , sec. 81, and Ohio Banking Law, Annotated, 1105.21 .
}

As the volume of business continues $t$ grow at a faster pace than the number of businesses, the trend during the postwar period has been toward 1 arger and larger business units. These larger business units also have larger credit needs. In addition, many corporate customers have become increasingly attracted to the use of term loans to meet their credit needs, and as the size of the corporate needs grow, the size of the lending banlis must expand to meet these needs. 20

${ }^{20}$ Francis W. Cuantlus, "Bank Mergers: important Factor in Economic Frowth," The Commercial and Financial Chronicle, Au ust 20, 1959 , p. 1.

Bank term lending has received competitive pressure from insurance companies, and the insurance companies have been able to strengthen thelr competitive position because they have kept better pace in size and loan 1 imits with the growth of the large corporations than have commercial banks. Although a number of banks can pool their resources to meet the credit needs of one large 
borrower, the method is cumbersome and may not satisfy the borrower. 21

${ }^{21}$ Statement by reorge A. Mooney, Superintendent of Banks of the State of New York, contained in House Commlttee on the Judiciary, Current Antitrust Problems, 1955, Part IIT, p. $200 \mathrm{~h}$.

Many bank managements have found that the swiftest method of attaining the additional capital needed to provide greater lending capacity is through a consolidation or mercer with another bank. Closely assoclated with the need for larger lending capacity is the fact that many local businesses and industrial concerns which were of major importance to local banks have been sold to large corporations which malntain their banking connections in metropolitan areas. In these cases the local banks usually receive a smaller percentage of the banking business of the local subsidiary. In an attempt to recover a portion of the lost banking business and to reduce the bank operating costs, the local banks sometimes find it advantageous to consolidate or merge with each other or with a larger metropolitan bank. 22

${ }^{22}$ Statement by the Comptroller of the Currency, contained in, House Committee on the Judiciary, Hearings, Current Antitrust Problems, 1955, Part I, p. 463. 


\section{E. Diversification}

Another motive for consolidations and mergers has been the desire to offer a complete line of banking services. A bank doing primarily a commercial business may seek to merge with a bank which does a large trust business. In many cases a bank which has been reluctant to enter into retail banking may seek to establish itself quickly as a consumer bank by merging with suburban banks and operating them as branch offices in order to attract the deposits and loans of consumers and small businesses located in the suburban areas. $^{23}$

${ }^{23}$ Statement of the Comptroller of the Currency contained in, House Committee on the Judiclary, Hearings, Current Antitrust Problems, 1955, Part I, p. 464.

Bank management may besome interested in merging. with another bank that has failed to develop a special banking service in an area where the acquiring bank management believes such services would be profitable. Many small banks do not have the varlety of services offered by a larger bank, and a merger might offer the larger bank an opportunity to expand its customers' services in a new and unexploited area. 24

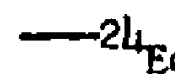

${ }^{2 L_{\text {Ed }}}$ Tyng, Burroughs Clearing House, December, 1960, p. 47.

On the other hand, an acquiring bank can be materially

influenced by the opportunity of acquiring special services developed 
to a high degree by the bank that is to be absorbed in a prospective combination.

\section{F. Market Position}

Any commercial or industrial enterprise that is to effectively compete in a highly dynamic economy must maintain a strong and viable market position. Maintaining a competitive position depends upon the ability of management to respond and adapt to changing demands of the customer, communtty, and the local economy. Consolidations and mergers have provided one of the methods which commercial and industrial organizations have employed to retain thelr market position.

Banks whlch have not grown proportionately have found themselves limited in ability to serve some of their old customers and handlcapped in their efforts to obtain new accounts. Competitive pressures force the bank to increase Its size. The desire to be one of

- the largest banks in the state, regi on or country for the greater prestige is a reinforcing factor. Mergers have been a solution which many banks faced with this problem have chosen. 25

\footnotetext{
${ }^{25}$ New England Business Review of the Federal Reserve Bank of Boston, Nay, 1959, p. 5.
}

In orcer to retain their market position many banks have entered into bank consolidations or mergers after a series of similar moves on the part of competitors. Char lotte and David Alhadeff polnt out that a number of acquisitions by a few banks are often sufficient to bring about a mave of mergers" in a banking 
market. They further state that the "wave of mergers" results from a defensive reaction on the part of other banks. The market position of these imitating banks is threatened, and the surest way of defending their market position is to enter into a retaliatory merger. ${ }^{26}$

${ }^{26}$ Charlotte P. Alhadef $r$ and David A. Alhadeff, Quarterly Journal of Economics, November, 1955, p. 518. .

\section{G. Bank Earnings}

The fallure of some banks to meet the changing demands placed upon banking during the postwar period has resulted in a poor earnings record. The primary cause of poor earnings is poor management. In a study conducted by the Federal Reserve Bank of Boston in 1958 1t was reported that the absorbing banks in the postwar bank mergers in the First Federal Reserve District were "more proititable, more aggressive, and more efficiently operated" than the banks which were acquired. 27 in a similar study conducted by the Federal

\footnotetext{
27 New England Business Review of the Federal Reserve Bank of Boston, May 1959, p. 6 .
}

Reserve Bank of Phlladelphla the following was reported:

In almost two-thirds of the mergers the absorbed bank had a higher capital ratlo (capital to risk assets) than the absorbing bank. Loans often were low and the absorbing bank had opportunities for more intensive and profitable use of capital funds. Our figures show that in almost seven out of ten mergers the absorbed bank had relatf vely lower earnings (as a ratio to capital accounts) 
than the absorbing bank. In nine out of ten mergers $1 t$ pald lower dividends (as a percentage of capltal accounts). 28

\section{${ }^{28}$ Business Review of the Federal Reserve Bank of Philadelphia, January, 1955, p. 5 .}

Some banks have been over-capitalized in the sense that their deposits could be considerably larger on the basis of their existing capital. In order to remedy this situation they have acquired other banks and have established new branches in growing areas in order to expand deposits and, hence, earnings. 29

${ }^{29}$ The Superintendent of Banks of New York 1isted the above average capital to deposits ratio of many large New York City banks as a primary factor in the postwar increase in bank mergers among metropolitan banks and suburban banks in and around New York City. George A. Mooney, Superintendent of Banks, New York, House Committee on the Judiciary, Hearincs, Current Ant1trust Problems, 1955, Part IIT, P. 2009.

IV. Regulation of Bank Consolfdations and Mergers

A. General Antitrust Legislation

The Sherman Antftrust Act of 1890 and the Clayton Act of 1914 were the first federal antitrust laws affecting bank consolidations and mergers. The purpose of the sherman Antitrust Act is to prohibit combinations in restraint of trade, and block attempts to form monopolies and gain monopolistic control of trade or commerce. Any consolidation or merger, regardless of how it was accomplished, may be attacked under the Sherman Antitrust Act if there is 
substantial proof that the transaction has resulted in an unreasonable lessening of competition. Although the Sherman Antitrust Act has been used against bank consolications and mergers, it has not been used extensively due to the doubt concerning the applicability of the antitrust laws to banking.

In 1959 the Department of Justice employed the Sherman Ant1trust Act for the first time in the field of banking, and the action was directed against a bank holiang company. In that case the Department of Justice acted to block the acquisition of the California Bank of Los Angeles by the Firstamerica Corporation. The Department of Justice consented to drop its case against the Firstamerica Corporation after the bank holding company agreed to a plan whereby it would organize a new bank with 65 offices and then "spinoff" the new bank within six years. This new bank will provide competition for the bank holding company affiliates. ${ }^{30}$ Early in 1961

30 House Select Committee on Small Business, Banking Concentration and Sma11 Business, 1960, pn. $44-45$.

the Department of Justice again employed the Sherman Act to block the merger of the First National Bank and Trust Company with the Security Trust Company both of which are located in Lexington, Kentucky. At this writing the case still remains in court. 31

31 Albert L. Kraus, "Governgent Eyes Banking Mergers," The New York Times, March 5, 1961, p. F 1. 
Section 7 of the Clayton Act, originally enacted in 1914, prohiblts a company from acquiring the stock of another company where the effect of the acquisition may result in a substantial lessening of competition. Banks are also subject to control under this act; however, section 11 of the Clayton Act authorizes the Board of Governors of the Federal Reserve System to enforce the provisions of this act where they are applicable to banks. 32

${ }^{32}$ Henry Harfield, The Business Lawyer, July, 1959, p. 1023.

The original section 7 of the Clayton Act pertained only to consolidations and mergers accompli shed through stock acquistions, but since national banks, member banks of the Federal Reserve System, and most state banks are prohibited from acquiring stock in other banks, the original section 7 had little applicability in bank mergers and consolidaticris. 3 ?

\footnotetext{
33 Senate Committez on Banking and Currency, Regulation of Bank Mergers, 1959.
}

The Eoard of Governors of the Federa1 Reserve System has exercised 1 ts power under section 11 of the Clayton Act only once. In June, 1948 the Board of Governors issued a complaint agalnst the Transamerica Corporation, then a west coast bank holding company, charging that the control of banking which the organization had acquired as a result of stock acquisitions was in violation of 
section 7 of the Clayton Act. In 1953 the Board of Governors abandoned the case after an unfavorable decision by a Federal Court of Appeals and a refusal by the United States Supreme Court to review the case. 34

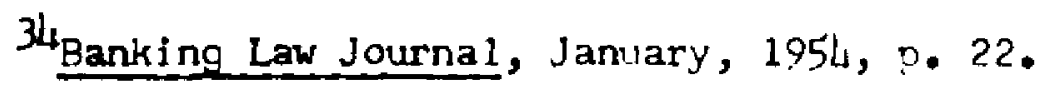

As was stated earlier, the original section 7 of the Clayton Act was applicable only to consolidations and mergers which were accomplished by stock acquisition. As a result, combinations which were accomplished via asset acquisition were not covered under the law. In 1950, however, section 7 of the Clayton Act was amended to include combinations by asset acquisjtion as well as stock accuisition. This amendment, however, did not include within its scope corporations other than those suhject to the jurisdiction of the Federal Trade Commission; and under sections 5 and 6 of the Federal Trade Commission Act and section 11 of the Clayton Act, banks are expressly exempt from the jurisdiction of the Federal Trade Commission. 35

${ }^{35}$ Statement of Emanuel Cellar, Representative from New York, contained in, Senate Committee on Banking and Currency, Regulation of Bank Mergers, 1959.

The effect of section 7 of the Clayton Act on bank combinations is negligible as a result of the exception provided in both the original act and the 1950 amendment. As one writer has stated it: The implications from these two laws when read together is that banks can acquire the assets of another 
corporation except as they may be subject, or as they

may be 1 imited by provisions under the Sherman Act. 36

\footnotetext{
$36_{\text {Edward }}$. . Gruis, "Antitrust Laws and Their Application to Banising," Banking Law Journal, Novemher, 1959, D. 79L.
}

Throughout the history of antitrust lenislation and $f$ ts enforcement in the United States there appears to have been considerable uncertainty concerning the extent to which antitrust laws are applicable to the field of banking. There seems to be a division of opinion as to whether banking should be treated as any other competitive industry, or should enjoy a status similar to a public utillty. It is generally agreed, however, that considerations other than perpetuation of competitive conditions must temper the applicam tion of the antitrust laws to the field of banking. 37

37 Carl w. Funk, "Antitrust Leglslation Affecting Zank Mergers," Eanking Law Journal, May, 1950, p. 369.

B. Banking Laws Pertaining Specifically to Consolldations and Mergers

Much of the confusion surrounding the regulation of bank consolidations and mergers is an outgrowth of the divided administration and regulatory authority connected with the comblnations. At the present time the Comptroller of the Currency, Board of Governors of the Federal Reserve System, Federal Deposit Insurance Corporation, and each state banking authority have some limited jurisdiction over bank mergers and consolidations. 


\section{Ohio Banking Law}

The Ohio law provides for consolidation, merger, and conversion of banks. The Ohio law permits a state bank to be absorbed by a national bank or convert to a national bank without the permission of the ohio Superintencient of Banks. In addition, the Ohio law permits a national bank operating in ohis to be absorbed by a state bank or convert to a state charter with permission only of the Ohio Superintendent i Banks. Two or more state banks in ohis may combine, of course, with the permission of the Superintendent of Banis.

The law requires, however, that before a combination may take place, a two-thiris majority of the shares of each bank must vote In favor of the consolidation or merger. The law states also that unless the corporation articles state otherwise, any shareholder of a state chartered bank in Shio who dis not vote in favor of any proposed consolidation or merger may request a fair cash value for his shares. 38

${ }^{38}$ Oni o Banking Lar, Annotated, 1103.37.

\section{Federal Banking Law}

In 1918 an amendment to the National Banking Act made it possible for one national bank to comblne with another national bank after receiving permission from the Comptroller of the currency. In 1927 the McFadden-Pepper Act provided for the direct combination of national and state banks under the national bank charter. It was not until 1950, however, that a national bank could be absorbed 
by a state bank or convert to a state charter without first undergoing dissolution. Before 1950 a national bank could not leave the national banking system except by dissolution. The dissolution of a national bank often resulted in a capital gains tax liability for the stockholders. As a result, few national banks were willing to surrender their national charter in order to be absorbed by a state bank or convert to a state charter. 39

39 Thomas 3. Paton, "Conversion, Meruer, Consolidation Legislam tion--'Two-Way Street' for National and State Banks," Banking Law Journa1, January, 1954, p. 15.

In 1950 the National Eank Conversion Act, or Public Law 706 (often referred to as the "two-way street law"), was passed by Congress which permitted a national bank to combine directly with a state bank uncier state charter or convert to a state charter without first undergoing dissolution and without permission of the Comptroller of the Currency. 40

40 Federal Code, Annotated, Title 12 , sec 214 .

Before a national bank may be absorbed by a state bank or convert to a state charter without permission of the Comptroller of the Currency, the state legislation, in the particular state, must permit state banks to be absorbed by national banks or converted to national charter without approval of any state banking authority. 
From 1945 to 1959 only four national banks in Ohio were absorbed by state banks, and there were no national banks converted to state chartered institutions. During the same period LO state banks in Ohio were absorbed by national banks, and five state banks were converted to national banks.

Federal law also provides that at least two-thirds of the participating bank' shares must approve a consolidation or merger before $1 \mathrm{t}$ will be approved by the Comptroller of the Currency. In addition, until 1952 the dissenting shareholders of each bank were entitled to recelve cash payment for their shares. In 1952, however, the National Banking Act was further amended to eliminate the right of dissenting shareholders in the absorbing bank to receive cash payment for their shares. This law applies, of course, only to national banks. The Comptrolier of the Currency stated that the purpose of the 1952 amendment was to el1minate the obstacle that dissenting stockholders of a large bank could provide to a combination of a large and a small bank. In many cases the threat of a substantial number of shareholders demanding cash for their shares has blocked the efforts of a large bank to absorb a smaller bank. 41

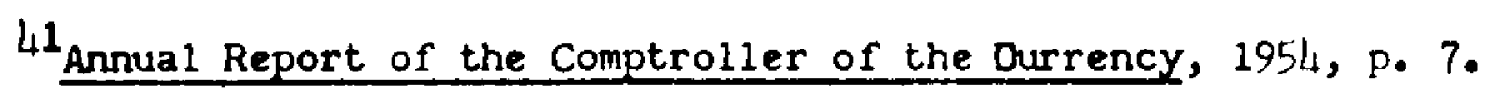

The federal law also provides for approval of the Federal Deposit Insurance Corporation and the Board of Governors of the Federal Reserve System in certain bank consolidations and mergers. 
Section $18(\mathrm{c})$ of the Federal Deposit Insurance Act recuires that before an insured bank may consolldate or merge with another insured bank prior written consent must be obtained from the Comptroller of the Currency if the resulting bank is to be a national bank, the Federal Reserve Board of Governors if the resulting bank is to be a state member bank, or the Federal Deposit Insurance Corporation if the resulting bank is to be a nonmember insured bank. In addition, if any insured bank desires to combine with a noninsured bank, the written approval of the Federal Deposit Insurance Corporation must be obtained regardless of whether the resulting bank is to be a national bank or a state member or nonmember bank. 142

$$
42
$$
Federal Code, Annotated, Title 12, sec. 1828(c)

Unt11 1960, approval of the Federal Deposit Insurance Corporation and the Federal Reserve Board of Governors was not necessary unless the capital and surplus of the resulting bank was less than the aggregate capital and surplus of the particlpating banks. This served as a serious obstacle to federal regulation of bank consolidations and mergers. 43 Passage of an amendment to section $18(\mathrm{c})$

43 In 1955 Governor J. L. Robertson of the Board of Governors of the Federal Reserve System reported that from 1950 to 1955 there were 162 cases of mergers and consolidations involving state member banks, but as a result of the rule that the Board of Governors approval was needed only in the case of a diminution of capital and surplus, only 81 of the mergers and consolidations were subject to the approval of the Board of Governors. U. 5. Congress, House 
Committee on the Judiclary, Hearings, H.R. 5948, Bank Mergers, 84th Cong., 1st Sess., 1955, p. 53.

in 1960 removed this qualification, and the approval of one of the agencles must now be obtained by an insured state bank regardless of the amount of capital and surplus of the resulting banis.

\section{Recent Legislation}

Throughout the postwar period Congress focused a great deal of attention on the bank consolidation and merger movement and the methods by which the regulatory agencies attempted to control the movement and retain a desirable level of competition in the banking industry. All of the participants in the various hearings and studies which were sponsored by Congress agreed that additional legislation was needed to prevent undesirable bank comblnations. Substantial disagreement has arisen, hovever, concerning the best method of providing greater control of bank mergers and consolidations.

The bank regulatory agencies have supported legislation which would provide greater control of bank combinations but would leave the regulation and review under their jurisdiction. Others have supported legislation which would eliminate the protection which banks have from the full force of the antitrust laws. This, in effect, would give the Department of Justice the right to decide whether or not a bank consolidation or merger should be approved, and the same means of determining the desirability of a combination in the nonbanking field would be applied to proposed banking combinations. 
The Comptroller of the Currency, Federal Deposit Insurance Corporation, Foard of Governors of the Federal Reserve System, and the National Association of Supervisors of the State Banks have opposed any legislation which would cive the Department of Justice the ultimate responsibility over bank mergers and consolidations. They argue that banking is a highly specialized field in which a substantial amount of familiarity with banking structure and operating policies is necessary in order to reach a sound decision on the merits of a proposed combination of banks. The Comptroller of the Currency stated the following:

Frankly, I don't believe that a group of lawyers sitting in the Department of Justice who have had lots of experience in antitrust work, in a myriad of fields, have the grasp of the banking business necessary to enable them to do a good job on that. We start with the fund of knowledge that it would take them a long time to acquire in any particular case.

$$
44_{\text {Ibid. }}, \text { p. } 76 .
$$

Those who support the plan to allow the Department of Justice to have ultimate responsibility over bank mergers and consolidations have based their argument on the need for uniformity of policy and greater attention to the effect of combinations on competition in banking. The proponents of this policy argue that the three federal banking agencies have falled to attain uniformity in their policies toward combinations, and that many consolidations and mergers are 
approved without adequate consideration of the ultimate effect upon compet 1 tion. 45

${ }^{45}$ Statement of Robert A. Ficks, Acting Assistant Attorney Ceneral, Antitrust Division, Department of Justice, contained in, House Committee on Ranking and Currency, Regulation of Rank Mergers, 1960 , p. 161 .

In 1960 Congress finally passed new legislation relating to bank consoliciations and mergers. The legislation attempted to meet many of the demands of both factions; however, it provicied that the primary authority in the regulation of bank combinations would remain with the bank regulator: agencies.

The legislation passed in 1960 amenced section $18(\mathrm{c})$ of the Federal Deposft Insurance Act, and it is referred to as Public Law 86-463. The amendment changed the law in three basic ways. First, as stated earlier, the powers of the Federal Deposit Insurance Corporation and the Board of Governors of the Federal Reserve System have been broadened in that they must give their approval to any member or nonmember insured state bank combination before the combination may be undertaken. Previous to the 1960 amendment the approval of these agencles was necessary only if the capital and surplus of the resulting banks was less than the aggregate capital and surplus of the participeting banks.

Second, the amendment broadened the number of factors which the three bank regulatory agencies must consider in evaluating proposed combination. Prior to 1960 they were required to consider 
the following: the financial history and condition of each of the banks involved, the adeguacy of its capital structure, its future earnirgs prospects, the general character of its manacement, the convenience and needs of the community to be served, and whether or not its corporate powers are consistent with the purposes of the Federal Deposit Insurance Corporation. The 1960 amendment addec a factor which requires the anencies to consicer the effect of the transaction on competition including any tendency toward monopoly. Third, in an attempt to bring about uni form standards among the federal bank regulatory agencies, all three anencies before approving a combination must request a report on the competitive effects of the proposed combination from the attorney reneral of the United States and the other two federal laning agencies. Aithough the law requires that the deciding agency must seek the advice of the other two banking acencies and the Attorney reneral, it is not obliged to heed the advice. In addition, the amendment requires that each of the regulatory agencies include in its annual report a description of each consolication or merger which it aprroved during the period covered by the report, along with general information on the banks involved, the opinion of the Attorney reneral concerning the effects upon competition that would result from each combination, and a statement as to why the combination was approved.46

Federal Code, Annotated, T1tle 12, sec. 1828(c) 
The disagrement between the two factions cannot be considered settled as a result of the passage of the 1960 act. Early in 1961 the Department of Justice filed suit to block two bank mergers which had been approved by the Comptroller of the Currency after the passage of the new legislation in 1960. Most bankers and regulatory officials consider this as an attempt by the Justice Department to test whether or not a regulatory agency can disregard the opinion of the Attorney General and approve a hank combination. Only after these cases have been ceciced will the effect of the new legislation be clear. 4 ?

47 Alhert L. Kraus, The New York Times, Marct 5, 1961, p. F 1.

\section{Summary}

Ohio was a leading state in the number of bank consolidations and mergers which took place from 1945 to 1959. A total of 106 banks were absorbed in Ohio during the 14 -year period, and the majority of these were absorbed after 1952. An analysis of the size of both the absorhed banks and the acquirin: banks reveals that all but a few of the absorbed banks had total resources of less than $\$ 25$ million, and 62.26 per cent of the acquiring banks had total resources of less than $\$ 50 \mathrm{million}$. These facts quickly dismiss any charge that the bank consolication and merger movement in ohio during the postwar perlod resulted in an increased concentration of banking resources and facilities among the largest banks in Ohio. 
Although each bank consolidation and merger has its own causative factors, there appear to be certain fundamental causes that are offered in most postwar mercers and consolications as the primary or secondary reasons for combinations. The consolidation and merger movement is closely associated with the expansion in branch banking activity. The economies that ray be realized in establishing a branch office via combination with another bank rather than undergoing the staffing problems, construction costs, and other difficulties encountered in establishing a de novo branch office have been of importance in the increase in bank consoliciations and mercers. The poor market for bank stock during the postwar period has also been a major factor. Many stockholcers of small banks have been able to realize a fair value for their shares only by consolidation or merger. The exchange of stock resulting from a combination has also proviced many bank stockholders with shares of a larger bank which offer larger dividends ani hetter marketability than the stock which they exchanged.

The prohlem which many small rural banks encounter in attracting successor management for aging or retired bank officers has often resulted in a decision to combine with another bank and allow the acquiring bank to provide management replacement from their staff.

The growth of business firms during the subject period resulted in the demand for larger loans and lines of credit from the banks which service these organizations. This has taxed the maximum 
loan limitations of incividual banks, ani it has constituted a sinnificant cause of baik combinations.

The increase in banir combinations also reflects the attempt of many banks to enhance or retain their market position and the desire to diversify their operations. The consolidation and merger device has enabled many banks to attain both of these objectives more rapidly than other methods they micht have employed.

Finaliy, the inability of many banks to earn a sufficient return on capital, and in other cases the overcapt talization encountered by both large and small banks, have served as an inducement to enter into consolidations or merners with other banks in an attempt to utilize bank capital more efriciently and secure a large enough market to enable the resulting bank to enjoy certain economies of scale.

In general, the postwar consolidation and merger movement in banking is a result of the banking incustry's attemts to adapt to the postwar changes in the institutional complex in which it operates. The changes in the local economy, the community, and the demands of bank customers have beer. the paramount cause of bank combinations rather than a conscious effort to eliminate competition and secure greater concentration of banking resources.

Through the regulation of bank consolidations and mergers an attempt has been made to preserve competition in banking. The antitrust laws have been of 11 mited usefulness aclainst banking combinations. The Department of Justice has applied the Sherman Antitrust 
Act agalnst banking combinations only twice. Section 7 of the Clayton Act has been of little value in attempting to block bank consolldations and mergers as a result of the $11 \mathrm{~m}$ ted applicability in the original section 7 and the exempt status of banking in the 1950 amendment to section 7 .

The primary legal restraints to bant comblnations lie in the specific state and federal statutes pertaining to bank consolidations and mergers. The Ohio law relating to bank combinations provides few limitations on bank consolidations and mergers. The federal law has been under Congressional review throughout the postwar period. All those participating in the Concressional hearincs on bank mergers agree that additional leglslation is desirable, but disagreement arises as to whether the ultimate responsitility for regulating bank combinations should rest with the Department of Justice or the three federal bank regulatory acencies.

In 1960 Congress amended the Federal Deposit Insurance Act to furnish the bank regulatory agencies with broader powers over bank combinations. The law provided for more attention to the competitive aspects of bank combinations by the regulatory agencies before approval is granted. It also attempted to ensure that greater uniformity of policy among the three agencies and the Department of Justice would be attained by requiring that each of the three federal acencies solicit the views of the other two federal bank regulatory agencies and the Department of Justice before aporoving a proposed consolldation or merger. 
Action of the Department of Justice since the passage of the 1960 leglslation would Indicate that the Department still seeks a stronger role in the approval of bank combinations, and the new law must be tested in the courts before its ultimate effect can be determined.

It is doubtfi:l if the highly regulated and supervised nature of banking justifies or recuires the strict adherence to what the Department of Justice views as a satisfactory amount of competition. Banking from 1921 to 1934 was highly competitive in the sense that a large number of small unit banks in local markets characterized the banking structure of the United States. It is generally recognized, however, that the disastrous collapse of the banking structure in the early 1930's was partially a result of a large number of small banks which were poorly managed and, as a result, unable to withstand economic adversity.

The purpose in maintaining a competitive system is the economic efficiency which such a system is thought to provide. It is recognized, however, that in some cases efficiency is better maintained by limiting the number of participants in a particular market or industry. The keenest competition is found among equals, and thousands of small unit banks have been threats to no one in banking. To insist upon a large number of independent banks may indirectly limit competition and perpetuate inefficlency. Those who Insist upon measuring competition in banking by the number and size of banks may, in fact, be encouraging inefficlency. 


\section{CHAPTER VI \\ SELECTED CASE STUDIES OF RECENT \\ BANK CONSOLIDATIONS AND MERGERS IN OHIO}

The purpose of this chapter is to provide a thorough analysis of the causes, methods, and effects of a select group of bank consolidations and mergers which took place In Ohio during the postwar perlod.

One of the primary shortconings of studies and Congressional hearings concerned with bank concentration during the postwar period is the fallure to consider bank consolidations and mergers from the standpolnt of the individual banks and communities involved. Throughout the numerous Congressional hearings on bank concentration the varlous state and federal bank regulatory agencies have objected to subjecting the benking industry to the fuld force of the antitrust 1aws. They have objected on the grounds that the Department of Justice lacks sufficient famillarlty with local banking conditions, bank management, and banking practice. The state and federal banking agencies, on the other hand, have been able to acquire an Immense amount of knowledge regarding bank management and management practices and the way in which these practices differ in the numerous local and reglonal banking markets. This knowledge is a result of the bank exanination and supervision activities in which these agencles are engaged. The agencies argue that this background and understanding of 
banking gives them greater ablilty to assess the desirablity of a proposed consolidation or merger.

Close examination of the local economic conditions, the structure of the banking market, the condition and management of the affected banks, and the methods of accomplishing a small number of carefully selected bank combinations provides a better understanding of the entire bank combination movement. This type of research can expose many facets of the bank combination movement which even the closest examination of the aggregate banking statistics can never reveal.

I. Methods Enloyed in Selecting the Case Studies

When the case method of research is used, the sample is more restricted than in other methods whlch might be employed. The other method, namely the questionnaire method, is not practical or useful, however, in attempting to conduct an exasination in depth. As a result, the samples for the case studies must be chosen with care to assure that the samples which are finally used are highly representative.

In selecting the cases for this study several criteria were used. First, to assure that equal representation was given to the different types of banking markets in Ohio, combinations were selected which were representative of banks in a predominantly agricultural market, banks in an Industrial area, and banks operating in a commercial or trade center. 
Second, closely associated with the selection of combinations according to the banking market, an attempt was made to ensure geom graphical diversification. The samples were selected with a view toward providing equal representation to the varlous geographical sectors of the state.

Third, the various sizes of banks were also considered in selecting the sample. As a result, combinations were chosen which included large, medium, and small banks in Ohi $\bullet$.

Fourth, representation was provided for both state and nationally chartered banks.

Fifth, attention was directed toward the methods by which the combination night be accomplished. As a result, the sample included cembinations which were achieved by consolidation, merger and purm chase of assets.

Finally, to assure that the detalls of the combination had not been blurred with the passage of time, comblnations which took place only after 1954 were considered. In addition, to assure that anple tine had passed to allow for sound analysis of the effects of the combl nation, any comblnation which took place after 1958 was ruled out.

After selecting a total of 15 bank combinations which took place between 1955 and 1958, and which net the standards previously di scussed, Interviews vere held with the Ohlo Super Intendent of Banks, the Supervising Exaniner in the Fourth District of the Federal Depesit Insurance Corperation, the Vice President in charge 
of the Exanination Department of the Federal Reserve Bank of Cleveland, and the Executive Manager of the Ohto Bankers Association. The purpose of the interviews was to solicit criticisn of the methods used in selecting the prelininary sample, and to enlist their ald in choosing the final sample from the 15 comblnations in the pre11 inary group.

There were no objections to the methods used in selecting the prelininary sample by any of the individuals interviewed. All agreed that liniting the sample to comblnations which took place after 1954 was an excellent 1dea, and they also approved of 1958 as a cutoff date in the selection. It was also noteworthy that all of the individuals interviewed were responsive to the Idea of using the case study approach rather than circulating questionnaires anong a large number of banks. They commented that the circulation of questionnaires has become so common a method of research that many of the bank officers who receive questionnaires elther delegate the work to a subordinate who has little knowledge of the information that is desfred, or the questionnalres are never returned.

The individuals interviewed were asked to select from the 15 conbinations those banks which in their opInion vere most representative and whose managenent would be willing to cooperate in a case study. Of the 15 combinations a total of five were Imediately eliminated on the grounds that it was highly doubtful if the present bank management would lend its cooperation to such research. An additional five combinations were elialnated on the grounds that some 
special circumstance which brought about the combination might render them less representative than the remalning five. Of the remaining five comblnations two resulted from quite similar clrcumstances. It was finally agreed that three of the initial 15 samples would provide a sound case study of the postwar bank consolidation and merger movenent in ohio.

The Ohio Bankers Association generously of fered to correspond with the three banks which were chosen to explain the purpose of the research and encourage their participation. All three banks agreed to cooperate in the study providing that the name of the banks and the communities in which the banks are located would not be disclosed in the study. In addition, the president of each bank agreed to participate in the study personally rather than assign another officer of the bank to the research.

of the three banks Involved in the study one is located in a predoninantly agricultural area, a second is located in a heavy Industrial area, and the third benk is located in a trade and aanufacturing center. Each bank is situated in a different geographical sector of the state, and they represent small, mediun, and large banking operations. Both state and national banks are represented in the study, and a different method of acquisition is represented In each of the three case studies.

In order to honor the agreement with the particlpating banks the names of the banks w111 not be disclosed and the resulting or acquiring bank in each of the case studies will be referred to as 
Bank $A$ and the absorbed bank as Bank $B$. In the case of the bank censelidation the two absorbed banks will be referred to as Bank $B$ and Bank $C$ and the resulting bank as Bank $A$.

\section{Case Study 1}

The first case study involves the combination in 1958 of twe banks which were located in different communities in the same southwestern Ohlo county. The absorbing bank, Bank $A$, is located in the largest community in the county which also serves as the county seat. The comunity has a population of approximately 9,000. The absorbed bank, Bank $\mathrm{B}$, was located in a coanuni ty of 1,000 inhabitants in the southwestern corner of the county approximately 15 alles from the county seat.

A. The Economic Base of the Banking Conmunity

In 1958 the county in which the two banks were located had a population of approxinately 32,000 . The county covers 412 square miles and has a population density of 78 inhabitants per square mile, as compared to an Ohio population density of 237 inhabitants per square mile.

The prinary economic activity in the county is agriculture. Approximately 90.1 per cent of the total land area of the county is devoted to farming, and in 1958 the county contained 1, L62 farms. In 1950 the county ranked 14 th anong all ohlo counties in the total anount of cash receipts recelved from agricultural products; however, by 1959 the county ranked 23rd anong all 88 Ohio counties. 
The leading agricultural products of the county are 11 vestock and dalry products. In $1958,79.0$ per cent of the total cash recelpts from agricultural products recelved in the subject county resulted from the sale of hogs, cattle, and dalry products.

Industrial and comercial activities have increased since 1945. In 1950 the subject county had approxinately 3,500 people enployed in industrial and comerclal activity, and by 1958 the number had increased to over 5,000. Manufacturing activity accounted for the largest number of employees in Industrial and comercial acti 1 ty. In 1958 nearly 2,300 individuals were employed in manufacturing firms, and approxinately 1,400 people were exployed in wholesale and retal 1 businesses in the county.

The primary manufacturing activity is 1 ight manufacturing and metal working. The value added by manufacturing increased from $\$ 4,329,000$ in 1957 , to $\$ 14,732,000$ in 1958 . The number of retal 1 establi shments in operation remained relatively stable during the postwar period, and the value of retall sales increased from $\$ 26,035,000$ in 1947 to $\$ 35,605,000$ in 1958 .

From 1950 to 1959, the total personal income in the county increased 90.0 per cent as compared to a 71.2 per cent increase for all of Oh10. Expressed on a per capita basis, the personal income of the subject county increased 53.6 per cent as compared to a 41.6 per cent increase for all of onfo during the same period. As a result, however, of its predoninantly agricultural economic base, the county throughout the postwar period had a lower per capita incone 
than the entire state. In 1959, the subject county had a per capita Incone of $\$ 1,846$ and the state of chio had a personal income per capita of $\$ 2,328$.

B. Competitive Position of Bank $A$ and Bank $B$

In 1958, prior to the acquisition of Bank B, there were seven comercial banks operating in the county. The total was composed of four national banks and three state chartered banks. A11 of the banks were members of the Federal Deposit Insurance Corporation, but only five of the banks were nenbers of the Federal Reserve System.

The banking resources in the county at that time totaled $\$ 27,500,000$. The national banks accounted for $\$ 23,000,000$ of the total, and the two largest banks held approximately 55 per cent of the total banking resources in the county. The two largest banks, both of whlch were national banks, were located in the county seat, and the remaining five banks were located in small towns throughout the county. The second largest benk in the county is an afflliate of the Bancohio Corporation.

During the same period there were four savings and loan associations in the county. The total resources of all of the savings and loan associations totaled approxinately $\$ 4,800,000$, and the largest association had total resources of $\$ 1,486,000$. The two largest assoclations were located in the county seat. None of them operated under a federal charter or held nembership in the Federal Savings and Loan Insurance Corporatien. 
In 1958 there were also four consumer loan offices in the county, and one credit union was in operation on a military base lecated in the county.

The banks lecated in the county also recelved a substantial amount of competition from large and aggressive financial institutions located in nearby metropolitan areas. The county seat is within 40 niles of two of Chio's five largest metropolltan areas.

1. Bank A

Bank $A$ is a national bank, and even before the combination it was the largest bank in the county. Table 35 presents the statement of condition for Bank A prior to the combination. At that time Bank A had total resources of $\$ 9,439,000$ which represented 34 per cent of the total banking resources in the county.

Bank $A$, prier to absorbing Bank $B$, did not operate any branch offices, nor did any other bank in the county. Bank $A$ operated the only trust department in the county, although the second largest bank had access to the services of the trust department of The Ohle National Bank in Colubus. This cooperative arrangenent had been werked out by the Banconio Corporation.

The President of Bank A reperted that the small loan offices provide substantial competition for automobile loans. Bank A estab1Ished an Installment loan department prior to World War II, and it had been active in granting loans for the purchase of constuner durables. 
TABLE 35

\section{Bank A}

Statement of Condition

December 31, 1957

\section{Assets}

Cash and in banks

\$ 1,564,000

U. S. government securities

3,033,000

Other securities

875,000

Loans and discounts

$3,640,000$

Bank buildings, etc. 312,000

Other assets

15,000

Total assets

$\$ 9,439,000$

Liablitties and Net Worth

Deposits

$\$ 8,471,000$

Other llabilities

27,000

Capital stock

250,000

Surplus

300,000

Undivided profit and reserves

391,000

Total liablities and net worth

$59,439,000$ 
The county seat contains a total of 18 manufacturing firas which are engaged primarily in setal working. Many of these organfzations are small firns and rely primarily upon the local banks for short and Internediate-tern capital. The President of Bank A reperted, however, that in recent years sone of the local manufacturing firms have been acquired by larger corporations whlch alntain their headquarters in nearby metropolitan areas, and they maintain all banking connections with one or more of the large metropolitan banks. This has resulted in a loss of business for the banks located in the coumty seat.

The prinary business of Bank $A$, however, is meeting the demands for agricultural credit. The President of Bank A explained that the expanding size of farms and the new mechanical methods of farming have forced the farmers to make substantial increases in their capital investment in erder to maintain an efficient operation. In an effort to gain a greater share of the agricultural credit market, Bank $A$ added an agricultural specialist to its staff for the purpose of advising local farmers on new techniques, and at the same tine to di seuss their credit needs with then.

2. Bank B

Prior to the acquisition Bank $B$ was the only bank in the saall rural comunity which it served. It had been the only bank in the community since 1915. In addition, it was the only financlal institution because the communlty had never been served by a savings and 
loan assoctation, small loan office, or any other type of financial institutions.

At the time of 1ts acquisition Bank $B$ was an insured nonmenber state bank, and It was the sixth largest of the seven banks operating in the county. Table 36 presents the statement of condition of Bank $B$ prior to the combination.

The comanity which Bank $B$ served is a small agricultural center, and all but a small portion of the loans which Bank $B$ held at the time of Its acquisition were agricultural loans. In addition, the community had two small locally-owned nanufacturing firms and a few commerclal enterprises such as grain elevators, a farm implement dealer, and the customary group of retallers that serve a farming comminity.

\section{Reasons for the Combination}

The board of directors of Bank B was cemposed of local farmers none of whos took an active part in the actual managenent of the bank. As a result, the cashier was placed in charge of the dally management of the bank, and he reported directly to the beard of directors. In the year and a half that preceded the comblnation, the board of directors of Bank $B$ had appointed a new cashier three tiaes. The President of Bank A reported that each time a new cashier was appointed he would soon be offered a nore attractive position with another bank as a result of his experience in managing Bank $B$. The inablity to retain a permanent replacement in the cashier's 
TABLE 36

Bank B

Statement of Condition

December 31, 1957

\section{Assets}

Cash and due from banks

\& 248,398

Bonds and other securities 703,810

Loans and discounts 580,170

Bank prem I ses 2,100

Other assets

3,038

Total assets

$\$ 1,537,546$

Liabilities and Net Worth

Deposits

$\$ 1,298,894$

Other 1 iablifies

142

Capital stock

60,000

Surplus

60,000

Undivided profits and reserves

118,510

Total liabillties and net worth

$1,537,546$ 
position was one of the primary reasons that the stockholders of Bank $B$ elected to 11 quidate the operation.

Another reason for the combl nation was the fact that nany of the stockholders were retired farmers 1 iving in the comunity or individuals who had inherited their shares and no longer resided in the comunity. Most of the stockholders no longer desired to retain ownership in the bank, but they found that no market existed for their shares. The opportunity to sell the assets to Bank $A$ was an ideal solution to their problem.

In an interview with a former director of Banis $B$, he commented that nany of the customers had requested that Bank B start offering new services, but the board of directors was reluctant to develop additional services for fear that the operating costs of the bank would be increased and a smaller proflt would result. In the opinion of the former director and the President of Bank A, Bank B had been a profitable operation. They both reported that Bank $B$ had shown an above average return on investment for a bank of its size. The board of directors had maintalned a pollcy of paying a sall but regular dividend.

The former director further stated that the entire board of directors, prior to the acquisition, began to realize that if additional services were not introduced the profit position of the bank would probably be adversely affected. As a result, the opportunity to sell the assets to Bank $A$ and to allow the latter to operate the local bank as a branch office would provide the community 
with the pdditional banking services it desired, and it would alse permit the stockholders to receive a falr price for their shares. From the standpoint of Bank $A$, the opportunity to acquire Bank $B$ was also attractive. The President of Bank $A$ stated that prior to the acquisition he had realized that if Bank $A$ were to continue to offer additional banking services a larger banking warket was needed to help absorb a portion of the fixed costs involved in the additional services.

The President of Bank A reasoned that if his banking market was to be increased, branch offices would have to be opened in the smaller conmunities throughout the county. He stated, however, that he was mare, as were the regulatory agencles which would have to pass on branch operations, that none of the smaller communities would support both a local unit bank and a branch offlce of his bank. His only cholce, therefore, was to try to acquire the local banks in these conmunities and operate them as branches.

After studying the problems of Bank $B$, the President of Bank A came to the conclusion that Bank $B$ had been managed too conservative1y. He based his conclusion on the fact that Bank B's total loans outstanding represented only 38 per cent of its total assets, but at the sane time requests for consumer loans, business loans, and residential real estate loans were being refused by the board of directors. He contended that by retaining the present business of Bank $B$, and in addition granting consumer, business, and residential 
real estate loans, Bank $B$ would prove to be a profitable branch office.

\section{Method of Combination}

The method of acquisition exployed in this particular case was a purchase of assets. The manaement of Bank A in negotiating the acquisition with the shareholders of Bank $B$ offered them a choice of two plans. The first plan called for a merger of Bank B into Bank A in which the stockholders of Bank $B$ would exchange thelr shares for shares of stock in Bank $A$ and $B$ would then be dissolved. Under the second plan Bank B was to undergo voluntary 11 quidation, and Bank $A$ would assume all the 11 abillties and acquire all the assets of Bank $B$. The net asset value would be pald to Bank $B$ and then distributed to Its stockholders.

The stockholders of Bank $B$, of which there were less than 50, elected to accept the second alternative. The president of Bank $A$ cormented that the board of directors of Bank $A$ favered the second method since they vanted to avold increasing the number of stockholders in Bank A. At the time of the acquisition there were approxinately 75 stockholders in Bank $A$.

Bank $A$ paid a snall premiun above the book value of Bank $B$ stock. The net asset value of Bank $B$ stock at the tine of the acquisition was approximately $\$ 240,000$, and the President of Bank $A$ stated that the stockholders of Bank B recelved $\$ 250,000$ in cash. According to the President of Bank $A$, the premiun resulted after a 
portion of the Investment portfollo of Bank $B$ had been valued upward from original cost to present market value.

\section{E. Changes In Banking Practice and Competition Which Resulted from the Combination}

The only basic change in the structure of the county banking system resulting from the acquisition was the fact that there was one less Independent bank, but the same number of banking offices realined in operation. Another change resulted from the fact that after the acquisition, Bank A controlled 40 per cent rather than 34 per cent of the total banking resources in the county.

After acquiring Bank $B$, the management of Bank $A$ deciced to retain the entire board of directors of Bank $B$ as an advisory board which meets once each month to advise the managenent of Bank $A$ on loan applications recelved by the branch office, real estate values, and the banking needs of the local community. The President of Bank A reported that the retention of the board of directors as an advisory group made the transition from a locally-owned bank to a branch office much easier and less objectionable to the local community.

In addition to the liberalization of the loan pollcy the management of Bank $A$ made other changes in the operations of the branch office. One of the first changes introduced was a complete remodelling of the branch office and the addition of several pleces of bookkeepling equfpment. A branch manager was appointed from the 
staff of Bank $A$, and as a part of his responsibility he began a vigorous campalgn of promoting the services of the branch office in the local community.

The writer visited the community where the branch bank is located for the purpose of interviewing local residents. In general, the people in the community seemed to be pleased with the change in banking practice.

The first person interviewed was the owner of an appliance and hardware store. In response to a question concerning his opini on of the change froa a local bank to a branch bank he replled that his business had increased as a result of the change. He explained that his appliance sales had increased significantly as a result of the local residents being able to secure installment loans from a local banking office. Prior to the acquisition many of the local residents purchased appliances at the county seat where they could obtain instaliment loans from one of the banks or from a consumer loan office located there.

The local farm Implement dealer expressed satisfaction with the change. He comented that the maximum anount that he could borrow from Bank B was 4,000 , but when the branch office opened the new management increased his 11 ne of credit to $\$ 12,000$ without his even requesting the increase.

The owner of a swall metal working shop stated that he favored the change because he also could borrow larger anounts from the branch bank that he formerly could from Bank B. He pointed out, 
however, that many of the local farmers had expressed dissatisfaction with the change. He explained that when Bank $B$ was in operation the board of directors was composed of farmers, and a loan applicam tion from a local farmer was approved with little question. Since the conversion of Bank $B$ to a branch offlce, however, the farmers making application for a loan are asked to provide more information concerning their operation. A grain elevator operator explained that many of the farmers view this change in policy as an attempt to interfere in their personal affairs. When asked if he agreed with the farmers he replied that he did not, and that with the passage of time he thought the farmers would accept the change as a part of necessary bank management.

A receptionist in a small manufacturing plant stated that as a result of beling able to finance the purchase of her new car through the local banking office she had transferred her checking and savings account from the competing bank in the county seat to the branch office of Bank A.

The owner of a men's clothing store commented that the remode1Ing of the banking office had improved the appearance of the business district. In his opinion the branch office was of much greater service to the entire communlty than the former bank had been.

\section{Case Study 2}

The second case study considers a consolidation which took place between two nedium-sized banks in 1955. The banks involved in 
the consolidation, Bank $B$ and Bank $C$, were both located in a communt ty of approximately 40,000 inhabitants in an eastern Ohio county. In addition to being the largest community in the county it also serves as the county seat.

A. The Economic Base of the Banking Community

The county in which the two banks were located serves as the major distribution and Industrial center of the Upper Ohio River Valley. In 1959 the county had a population of 100,501. The county covers 411 square miles, and it has a population density of 245 Inhabitants per square mile which is slightly in excess of the average population density of Ohio.

The primary economic activity in the county is manufacturing and mining. Manufacturing activity centers around steel and chenlcal production. In 1958 the county ranked 15th among the 88 ohfo counties in total value added by manufacturing. In that year the value added by zamufacturing in the county was $\$ 118,088,000$ as compared to $\$ 53,652,000$ in 1947. Of the 19,091 people employed in Incustrial or commercial activity in the county in 1958, approximately 50 per cent were aployed in hanufacturing firms.

Because of the low cost transportation facllities provided by the Chio River, the abundance of natural resources, and other econoufe reasons, scores of new industrial plants have been bulit in and around the county during the postwar period. 
In 1958 the county ranked third among all Ohio counties in the number of tons of bituminous coal produced. The value of the coal produced in 1958 was $\$ 12,841,345$ as compared to $\$ 18,437,616$ in 1950. The importance of coal production in the county has been declining since the end of World War II. In 1950 there were 2,558 people employed in mining, and by 1958 this number had declined to 1,010. The payroll resulting from mining activity in the county in 1950 totaled $\$ 9,056,000$ as compared to $\$ 4,739,000$ in 1958 . In addition, surface mining accounted for nearly 70 per cent of the coal produced in 1958 as compared to approximately 50 per cent in 1950. From 1947 to 1958 the total sales of retall establl shrents in the county increased from $\$ 78,906,000$ to $\$ 113,782,000$, and the total sales of services increased from $\$ 6,680,000$ to $\$ 8,057,000$ during the same perlod.

The county is of minor importance from the standpoint of agricultural production, and agricultural activity has continued to decline throughout the postwar period. Between 1954 and 1959 the proportion of all land in the county devoted to agricultural production declined from 53.7 to 43.6 per cent of the total land are a During the same perlod the number of farms in operation was reduced from 1,273 to 871 . One of the major factors in the reduction of agricultural activity is the increased amount of land being consuned in "strlpmining."

Due to the importance of steel, chemical, and coal production In the region it has often been referred to as the "Ruhr Valley of 
the United States"; however, the economic base of the county also provides some rather serlous economic problems. During periods of economic recession it is one of the earliest and hardest hit areas of unemployment. In addition, the coal industry has provided an unemployment problem throughout most of the postwar period. From 1950 to 1959 the total personal income of the county increased by 51.5 per cent while total personal Income in Ohio increased 71.2 per cent. The personal incone per caplta in the county, however, placed 15th among all ohio counties in 1959. In that year the per capita personal income in the subject county was $\$ 2,158$, and the per capita personal income in Ohio was $\$ 2,289$.

B. Competitive Position of Bank $B$ and Bank $C$

In 1955, prior to the consolidation of the two banks, there were 13 commercial banks and 15 banking offices in the county. The banks were composed of five national banks and elght state chartered banks. Al1 13 banks were nembers of the Federal Deposit Insurance Corporation, but only the five national banks held nembership in the Federal Reserve System.

The resources of the 13 banks in 1955 totaled approximately $\$ 98,000,000$, and the total was evenly divided between the natlonal and the state banks. The largest bank, a state bank, accounted for $\$ 25,828,191$ of the total. The four largest banks in the county were composed of two national banks and two state banks, and together they controlled 83 per cent of all the bank assets in the county. All 
four of the banks were located in the county seat, and two of the banks operated one branch office each.

In the same year there were four savings and loan assoctations in operation in the county. The aggregate resources of the four associations approxinated $\$ 19,500,000$, and the largest of the four accounted for $\$ 8,700,000$ of the total. None of the associations operated under a federal charter, and only one was a nember of the Federal Savings and Loan Insurance Corporation. Three of the four associations were located in the county seat, and none of them operated branch offices.

There was only one credit union in the county in 1955, but there were numerous consumer loan offlces in operation.

In addition to the intracounty conpetition, the subject banks also received a substantial amount of competition from banks located In Plttsburgh, Pennsylvania, and Wheeling, West Virginfa.

1. Bank $\underline{B}$

Bank $B$ was a national bank and the second largest bank in the county. At the time of consolidation Bank $B$ had total assets of \$25,575,099. Table 37 presents the statement of condition of Bank B prior to the consolidation. At that time Bank B controlled approximately 25 per cent of the total bank resources in the county. Bank $B$ did not operate any branch offices, and the majority of Its business consisted of business loans and accounts. The trust departaent of Bank $B$ was the most active and successful in the county. 


\section{TABLE 37}

Bank B

Statement of Condftion

October 5, 1955

Assets

Cash and in banks

+ $4,214,190$

Unlted States government securities

$11,032,866$

Other securlties

$1,762,371$

Loans and discounts

$7,977,417$

Bank prealses

407,377

Other assets

180,878

Total assets

$\$ 25,575,099$

\section{Llabilities and Net Worth}

Deposits

$\$ 23,771,920$

Other 11 ablities

114,979

Capltal stock 500,000

Surplus 800,000

Undivided profits 282,247

Reserves 105,953

Total 11 ablifties and net worth

$\frac{105,953}{25,575,099}$




\section{Bank $\subseteq$}

Bank $C$ was also a national bank and the third largest bank in the county. At the time of consolidation Bank $C$ had assets totaling $\$ 14,923,537$. Table 38 presents the last statement of condition of Bank C prior to the consolidation.

The primary business of Bank $C$ was business loans; however, shortly before the consolidation the managenent of Bank $C$ became interested in gaining a greater share of the retall banking market, and a branch office of Bant $C$ was opened in a small residential conmunity near the county seat.

According to the President of Bank $A$, the bank resulting from the consolidation, the earnings of both Bank $B$ and Bank $C$ had been sat1sfactory, and they both earned an above average return on investment.

\section{Reasons for the Comblnation}

The President of Bank A reported that the consolidation of Bank $B$ and Bank $C$ had been under consideration by the managenent of both institutions for at least five years prior to 1 ts completion. In 1953 the consolidation was smost completed when a disagreement arose concerning who would act as the President of the resulting bank, and a reconciliation was not reached until 1955.

The primary reason for the consolidation was the need for a larger beak in the comunity to meet the growing denand for short and Intermedlate-tern loans by comercial, manufacturing, and aining 
TABLE 38

Bank C

Statement of Condition

October 5, 1955

\section{Assets}

Cash and in banks

1 2,521,516

United States government securities

$5,153,360$

Other securities

$2,011,500$

Loans and discounts

$4,904,094$

Bank premises

333,067

Other assets

Total assets

\$ $14,923,537$

Liabilities and Met Worth

Deposits

$\$ 13,663,317$

Other liablifties

124,235

Capital stock

500,000

Surplus

500,000

Undivided profits

135,985

Reserves

Total 11abilities and net worth

$\$ 14,923,537$ 
enterprises located in and around the county. As a result of the rapid economic growth of the Upper Ohio River Valley during the postwar period many of the local business firms required larger lines of connercial bank credit. The local banks, however, had not expanded as rapidiy as the businesses which they served, and they were encountering Increased difficulty in meeting the business credit needs as a result of the federal and state law which prohibits making loans to any one person or corporation in an amount exceeding 10 per cent of capital and surplus of the bank.

Because of this restrictlon many local borrowers were being forced to seek the loan services of larger banks in Pittsburgh and Wheeling. The Pittsburgh and wheeling banks required that compensating balances be malntalned by the borrowers, and this in turn resulted in not only a loss of the loan business but also a loss of deposits for the subject banks.

The President of Bank A commented that prior to the consolidam tion, Bank $B$ and Bank $C$ had cooperated in making business loans that were too large for elther bank to make independently, but he stated that this system was unsatisfactory from the standpoint of where the compensating balances would be naintained. He also pointed out that many business firms avolded this type of lending since they preferred to deal with only one bank.

Another factor which favored the consolidation was the difference in the managment of the two banks. The President of Bank $B$ had been an anployee of the bank since 1905, and he directed the operation of 
his bank with little asslstance. He had made no provision for successor management, and he was reluctant to delegate any of his responsibility so that his subordinates could acquire the experience needed to operate the bank. The President of Bank $C$, on the other hand, was a retlred industriallst who knew little about banking, and he was dependent upon his subordinates for the wanagement of the bank. As a result, Bank $C$ was vell prepared with successor management. By comblining the two banks the resulting bank was directed by a capable president with a well-tralned staff. Upon consolidation, the President of Bank $B$ becane the President of the resulting bank, and two years later he retired from that post. HI s successor was formerly the Executive Vice President of Bank C.

A third factor which prompted the consolidation was the location of the two banks. Prior to the consolidation the two banks had been located directly across the street from each other. Bank $C$ was unable to acquire property for expansion, and the managenent faced the prospect of having to relocate and construct a new building. The anagement of both banks realized that a comblnation of the two banks would result in a substantial reduction in operating costs and the opportunity to avold an umecessary duplication of facilities. After the consolldation was carrled out, the resulting bank was located in the 12-story bullding which formerly housed Bank $B$, and the bullding which Bank $C$ had occupled was sold. The branch office which Bank $C$ had operated was maintained and operated as a branch office of Banik $\boldsymbol{A}_{\text {. }}$ 
The President of Bank A comented that a further consideration In the consolfdation was the fact that the managenent of both banks reallzed that additional capital would have to be ralsed regardless of whether or not the consolldation was carrled out. They reasoned, however, that it would be more efficient to allow one larger bank to ralse the capital than for the two banks to attempt independentiy to sell additional stiock.

In 1957, two years after the consolidation, Bank A decided to issue an additional 37,500 shares of common stock through a privileged subscription. The Ohlo Company, an investment banking firm, agreed to underwrite the issue on a standby agreenent. In an interview with nembers of the Statistics Department of The Chio Company it was learned that 26,959 shares were subscribed. Of the 13,541 shares which The Ohio Company acquired, a total of 5,150 shares were acquired during the subscription period. As a result of the sale of additional stock, the number of stockholders in Bank $A$ increased from approximately 200 in 1957, to over 500 in 1959. The President of Bank A expressed the oplnion that the increased number of stockholders improved the narketablllty of the bank's stock and the prospects for ralsing additional capital in the future. He al so commented that nefther of the absorbed banks could have afforded the sorvices of The Onlo Company, and in his opinion the investment banking firm had been a major factor in the successful sale of the stock. 


\section{Method of Combination}

Under the agreement between the two absorbed banks a new corporation was formed under the national banking charter of Bank B. The reason for retaining the charter of Bank B rather than Bank C was the fact that the charter of Bank B was originally granted in 1865 one year after the Natlonal Banking Act was passed by Congress, and it is one of the oldest national bank charters In Ohio.

All of the assets and liablitties of the absorbed banks were then transferred to Bank A. Bank B contributed 59.92 per cent of the aggregate fair value of the net assets of Bank $A$, and Bank $C$ corm tributed 40.08 per cent.

The anount of capital stock of the new bank was $\$ 1,000,000$, and It was divided into 100,000 shares with a par value of $\$ 10.00$ a share. The stockholders of Bank $B$ recelved 60,000 shares of Bank A in exchange for all of the stock of Bank $B$, and the stockholders of Benk C recelved 40,000 shares in exchange for all the stock of Bank C.

The President of Bank A stated that the consolidation method was employed in order to overcome possible objections from stockholders or employees. He commented that the boards of directors of both banks were of the opinion that if each bank were treated as an equal in the conbination, rather than to allow one bark to absorb the other and continue operation under its former name, it would prevent 111 feeling on the part of the stockholders, employees, and customers. In discussing the success of the consolidation the President of Bank $A$ pointed out that not one dissenting vote was cast 
by the stoctholders of el ther bank, all employees of both banks were retained in the new bank, all nembers of the board of directors of both banks were appointed as members of the board of directors of Bank $A$, and only a few eustoners were lost as a result of the consolidation.

\section{E. Changes in Banking Competition and} Practice Resulting from the Consolidation

On December 10, 1955 the two banks vere consolidated, and on Decenber 31, 1955 the resulting bank held assets totaling $140,200,170$. As a result of the consolidation Bank $A$ becane the largest benk in the county, and at the end of 1955 it controlled approxinately 40 per cent of the total bank resources in the county.

In the four years which followed the consolidation, Bank $A$ acquired four of the small state banks in the county through either merger or purchase of assets. All of these banks were located in small communities, and Bank A contlnued to operate then as branch offices. By the end of 1959, Bank A was operating a total of $s i x$ banking offlces, and it controlled 46 per cent of the total banking assets in the county.

When asked what advantages accrued fron the consolidation, the President of Benk A replied that in his opinion it is the responsibility of management to see that the bank is operated in a manner that assures that adequate banking services are provided the pubilic. He stated that the consolldation from which his bank resulted and the 
mergers and purchase of assets in which his bank had been Involved since that tine were the means of providing the banking services which the banks in the county had theretofore been unable or unwillIng to provide.

The consolidation also brought advantages to the operation of the resulting bank. The President of Bank A pointed out that the investment portfollo of the bank is now large enough that the services of an Investaent counselor are ut111zed, and the result has been a more profitably managed portfollo.

The larger size of the resulting bank has also made it possible to provide formal training for many of the bank employees. Trust officers of the bank are oc casionally sent to New York City to attend a training progran for trust officers sponsored by the Chase Manhattan Bank of New York. Employees in the loan department are sent to Cleveland to attend a course for loan officers sponsored by the Central National Bank of Cleveland. In addition, employees are encouraged to attend the banking schools sponsored by the Americen Institute of Banking and the Onio Bankers Association. Bank A also has formal training prograns for employees in the trust department, loan department, accounting department, and the savings department. The President comented that Bank $A$ is the only bonk in $t$ he county large enough to be able to support this type of eployee training.

In addition to eaployee training, the bank has encountered less difficulty attracting and retaining personnel as a result of a higher salary seale introduced soon after the consolidation, and an 
employee pensfon plan in which all contributions are made by the bank. Bank $A$ is the only bank in the county which provides a pension plan for employees.

Bank $A$ has been able to recover much of the business which was lest to Pittsburgh and theeling banks. An owner of a manufacturing firm reported that as a result of his betng able to acquire the loans he needed from Bank $A$, his average balance in Bank $A$ had increased from between $\$ 10,000$ and $\$ 20,000$ to over $\$ 100,000$. Previously his firm borrowed from a bank in Pittsburgh which insisted that the firm maintain large compensating balances.

An automoblle dealer commented that with the establishment of Bank A it became possible for the local autcomoblle dealers to finance a large inventory of new cars through a local bank. Previous to the formation of Bank $A$ he had used a sales finance organization, and the local banks loaned to the sales finance organization at a much lower rate than the automablle dealer recel ved. He comented that with the formation of Bank $A$ the sales finance organlzation was no longer used, and as a result both he and the bank were doing a "little better" on rates.

An officlal of the Chamber of Commerce stated that with the formation of Bank $A$ the local banking structure became more compet1tive. He pointed out that Bank $A$ had adopted a pollcy of establishing branch offices throughout the county, the first bank in the county to provide a drive-in window for its customers, and the first to actively promote the services of the bank to the public. He expressed 
the opinion that as a result of the conpetition a combination of the second and third largest bank in the county might take place. He admitted that there was little, if any, price competition anong the banks, but he argued that there was a substantial amount of competition in banking services. He concluded the interview by stating that the majority of bank customers in the county had desired better banking service, and that the bank consolidation had provided the means whereby these services could be made aval lable.

\section{Case Study $\not 3$}

The third and last case study considers a merger which occurred between a large bank and a medlum-sized bank in 1958. Both banks were located in the same metropolitan area in central Ohio.

\section{A. The Economic Base of the Banking Community}

The metropolitan area in which the two banks operated encompasses a substantial portion of the county in whlch it is located. In 1958 the county had a population of approximately 650,000, and it covered 538 square miles. It had a population density of 1,298 Inhabitants per square mile as compared to 237 per square alle for the entire state. In addition, the population of the county had Increased by 34.7 per cent between 1950 and 1959 as compared to a 21.4 per cent increase for all of onlo.

The metropolitan area serves as the major trade and distribution center for central oni 0 . In addition, the county has benefitted 
from extensive increases in manufacturing activity during the postwar period. Manufacturing activity centers around metal processing and fabricating, shoe and textile production, manufacture of wood and paper products, and a limited amount of chemical production. A number of branch plants of national organizations have been estabIf shed in the county since the end of World War II. The increase in manufacturing activity can be attributed primarily to geographlcal location.

The comminity is an excellent distributing point for both consumer and Industrial markets throughout the north central section of the United States. The community also offers accessibility to industrial raw materials, and it provides adequate transportation facilities. For many comoditles the county has becone a manufacturing In-transit point. Steel and other metallic raw materials move from the production centers in Cleveland and Pittsburgh into the community for further processing and fabrication. The fabricated parts are then shipped to the assembly centers in Indiana and Michlgan. The establishment of the branch plants of national organizations has also stimulated the formation of smaller mamufacturing firns that provide subcontracting services. In 1959 approximately 181,000 people were employed in Industrial and comercial activity in the county, and of that total 70,000 were engaged in manufacturing. The county ranked fourth among all onlo counties in 1958 in the value added by manufacturing. Between 1947 and 1958 the total value 
added by manufacturing in the county increased from $\$ 277,964,000$ to $\$ 613,870,000$.

Approximately 30 per cent of the Industrial and commerclal employment in the county is provided by retall and wolesale estab11 shments. Proof of the county's importance as a trade center is the fact that in 1958 the sub ject county ranked third among all Ohio counties in total sales by retall establishments. In that year the total sales of retailing establishments were $\$ 852,633,000$. In addition, the sale and distribution of services plays an important part in the economy of the cormunity. In 1958 the county had 3,639 service establishments with total sales of $\$ 132,303,000$ as compared to 2,991 service establishents in 1954 with total sales of $\$ 88,281,000$.

Agricultural activity is of some importance in the county, and in $1959, \$ 14,556,000$ in cash recelpts were earned from agricultural production. The proportion of total land area devoted to agricultural production, however, declined from 63.2 per cent in 1954 , to 57.8 per cent in 1959.

In addition, a substantial amount of employment and incone ie derived from the operation of various state and federal government agencles located within the county.

As a result of the diversification in its economic base, the economic recessions which have created serious social and economic problems in other Ohio communitles have not serlously affected the subject county. From 1950 to 1959, the estluated personal income in the county Increased by 89.4 per cent as coupared to a 71.2 per cent 
increase in all of Chlo. Due to the rapld increase in the population of the county, however, the per capita personal income advanced at the same rate as the balance of the state. In 1959 the per capita personal income in the county was $\$ 2,523$ as compared to $\$ 2,289$ for the entire state.

\section{B. Competitive Position of Bank $A$ and Bank B}

In 1958, prior to the merger of the subject banks, there was a total of 16 comercial banks operating in the county. The banks were composed of four national banks, and 12 state chartered banks. all 16 of the banks were nembers of the Federal Deposit Insurance Corporation, and the four national banks and one state bank held nembership in the Federal Reserve System. A total of nine of the 16 banks were operated within the metropolitan area, and seven of the banks operated a total of 28 branch offices throughout the county.

The resources of the 16 banks in 1958 totaled approximately $\$ 853,000,000$, and of that total the four national banks accounted for $\$ 732,000,000$. The three largest banks in the county were all national banks, and together they controlled approximately 84 per cent of the total resources in the county. In addition, two of the three largest banks controlled 22 of the 27 branch offices in the county In 1958. The largest of the 16 banks held assets which totaled $\$ 414,000,000$, and It operated 18 branch offices.

The savings and loan assoclations in the county are very aggressive competitors for the banks. In 1958 there were a total of 
21 savings and loan associations in operation in the county, and the aggregate assets of the associations totaled $400,000, \infty 00$. Eleven of the savings and loan associations operated under a federal charter, and all but one of the 21 associations belonged to the Federal Savings and Loan Insurance Corporation. There were also 15 branch offices of savings and loan associations in operation within the county. The largest association was a federal chartered institution, and it held total resources of approxinately $\$ 70,000,000$ in 1958. At the end of 1957 there were 72 credft unicns and approxinately 70 consumer loan offlces operating in the county.

1. Bank $\underline{A}$

Bank $A$ is a national bank and the second largest bahk in the county. In addition, it is one of the 15 largest banks in Ohlo. At the time of the merger Bank $A$ held assets totaling $\$ 176,700,373$. Table 39 presents the statement of condition for Bank A prior to the merger. In 1958 Bank A controlled nearly 24 per cent of the total bank assets in the county.

Prior to the merger Bank $A$ did not operate any branch offices. The primary business of the bank consisted of business loans and accounts. Previous to the merger the management had shown a mild interest in developing a retal1 banking business, but little had been done to promote and develop this aspect of the banking business. Bank $A$ was also active in developing correspondent banking relationships. 


\section{TABLE 39}

Bank A

Statement of Condition

March 4, 1958

\section{Assets}

Cash and in banks

$+58,268,871$

United States government securities

$45,168,591$

Other securities

$11,664,132$

Loans and discounts

$57,690,328$

Bank prenlses

$3,035,378$

Other assets

873,073

Total assets

$\$ 176,700,373$

\section{Liablifties and Net Worth}

Deposits

$+158,528,286$

Other liabilities

$3,266,296$

Capital Stock

$6,000,000$

Surp1us

$7,000,000$

Undlvided profits

$1,905,789$

Reserves

Total liabllities and net worth

$176,700,373$ 
2. Bank $\underline{B}$

Bank $B$ was a state chartered nonmember bank, and the fourth largest bank in the county. Table 40 presents the last statement of condition for Bank $B$ prior to the merger. At that time Bank $B$ had total assets of $\$ 32,113,098$, and it controlled 4.3 per cent of the total bank resources in the county.

Bank $B$ was also without any branch offices, and the primary business of the bank was providing local businesses with short and Internedlate-term credit. The bank had developed sound customer relationships with many retall and wholesale business firms. Bank $B$ also had a large number of personal deposits, but it offered few retall banking services.

\section{Reasons for the Combination}

The President of Bank A stated that although Bank A had remalned the second largest bank in the county throughout the postwar period, the proportion of the banking market which it controlled had declined during the same period. In 1945 Bank $A$ controlled nearly 30 per cent of all the bank assets in the county, but by 1958 it held less than 24 per cent of the total. The largest bank in the county, and the chlef competitor of Bank $A$, had increased its share of the total bank resources in the county from approximately 40 to 48 per cent during the same period.

Between 1945 and 1958 Bank A did not open any branch offices or conbine with any other banks. The largest bank, however, opened 
TABLE 40

Bank B

Statement of Condition

March 4, 1958

\section{Assets}

Cash and in banks

$\$ 3,953,714$

United States government securities $15,766,881$

Other securities $4,400,076$

Loans and discounts $7,975,214$

Bank prenises

Other assets

17,212

Total assets

$32,113,098$

Liablifies and Net Worth

Deposits

$\$ 29,508,619$

Other llabllities

955,077

Capital stock

600,000

Surplus

600,000

Undivided profits

349,402

Reserves 100,000

Total 11abli1ties and net worth

$\frac{100,000}{32,113,098}$


seven branch offices and absorbed two other state banks during the same period. In addition, the third largest bank in the county opened four branch offlces during the postwar perlod.

It was the opinion of the management of Bank $A$ at the time of the merger that the reason for the success of the county's largest bank in capturing a greater share of the banking market was its retail banking practice which was promoted through its branch offices. Until 1950 Bank A would not make residential real estate loans, and it was even later in the postwar period before a polfcy of making consumer loans was adopted.

Wuch of the conservatism in the operating policies of Bank $A$ resulted frow the fact that the management of the bank remained under the control of men who viewed the role of a commercial bank as serving the credit needs of business and little else. Later in the postwar perlod, however, the management of the bank began to change as a result of death and retlrement. The new nanagement began to realize that if Bank $A$ were to maintain its position in the banking market and attempt to recover that part which had already been lost, the former polfcy of limiting retail banking would have to be reversed. They reasoned that the soundest method of acquiring branch offices was to comblne with smaller banks in the communty in order to gain the advantage of estab1lshed customer relatlonships and existing deposits.

Bonk $B$ was located in a section of the metropolitan area that had formerly been ldeally sulted for a bank serving comercial 
enterprises, but due to shifts in the location of the conmerclal section of the city, and the movenent of businesses and banking offices to suburban shopping centers, Bank B lost much of its advantage. In addition, the bank was located on the edge of a mium area," and plans had been made for reclanation of the area. There were tentative plans to convert the area into a combination of low cost housing and governnent offices. Fortunately, the reclamation plans did not include the bullding in which the bank was located, and Benk $B$ had signed a 99-year lease for the bullding in 1921 which carried a very reasonable annual lease payment.

The management of Bank $B$ realized that if the reclamation plans were carried out its location would possibly be of much greater value as a branch office than as a unit bank. With the increase in office employees and residents which the reclamation would bring near the bank, the personal deposits would increase rapidly, and the opportunIty to make consumer loans would be enhanced. At that time Bank $B$ did not make consumer loans, and the addition of a consumer laan department would have required an expansion in physical facilities. The balance of the butlding in which Bank B was located had been subleased to a state government agency, therefore, any expansion which Bank $B$ night have undertaken would have been in another location. The ownership of Bank $B$ was closely held, and the largest stockholder served as the President of the bank. He was a young man who had numerous business investiments, and many of these interested him more than banking. He was not willing, however, to become an 
absentee owner of the bank. It was his desire to exchange his ownership in Bank B for shares in a larger bank which offered greater marketability, and a bank which had greater diversification in its operation.

The reputation and background of Bank $A$ and Bank $B$ were quite similar. Both banks had been formed in the latter part of the 19th century by familles who were still active in the management of the banks. Both banks had derived their business from serving industrial and comerclal enterprises in the region. The similarity between the two banks served as a further stimulus to merge.

The President of Bank A stated that at the time the merger was being considered, the managenent of Bank $A$ viewed the acquisition of Bank $B$ as an excellent opportunity to initiate a policy of branch banking. The fact that Bank $B$ was an established bank with existing deposits and an experienced staff provided Bank $A$ with the opportunity of acquiring its first branch office with a minimum of organization and personnel problens. In adjition, the acquisition of Bank $B$ would permit Bank A to acquire a branch office without investing in additional property since Bank $B$ leased rather than owned the building in which it was located. The additional space which was needed to open a consumer loan operation could be provided by combining many of the activities of Bank $B$ with similar activities in Bank $A$ and thereby creating additional space in the present Bank B location. The President of Bank A stated that even if the reclamation plans should not materlalfze, Bank $B$ had been a profitable operation 
previous to the merger, and there was no reason to belleve that this could not be continued and even improved upon through the reduction of operating costs resulting from the merger. He pointed out that one of the strongest assets of Bank $B$ had been an excellent personal relationship with its customers.

\section{Method of Combination}

The nethod of combination employed in this case was a merger. According to the agreement between the two banks, Bank $B$ was absorbed Into Bank A.

This method of combination was chosen for two reasons. First, Bank $A$ was a large and well-known bank throughout ohlo; therefore, it was $\log$ ical that the name and charter of Bank $A$ would be retalned. Second, the major stockholder of Bank $B$ desired to avoid paying any capital gains tax that might have resulted from a purchase of assets. He also desired to hold shares in a larger bank as was prevlously mentioned.

In exchange for 60,000 shares of common stock of Bank $A$, the shareholders of Bank $B$ surrender ed 60,000 shares of stock of Bank $B$. The aggregate book value of the shares which the stockholders of Bank $B$ surrendered was $\$ 1,649,402$, but the aggregate estimated fair value of the shares was $\$ 3,464,684$. The difference between book value and fair value of the shares resulted from a revaluation of assets. The President of Bank A reported, however, that none of the Bank B stockholders insisted upon a cash payment for their shares. The 
board of directors of Bank $A$ after the merger consisted of 16 members which were composed of the 14 members of Bank A prior to the merger, and two members of the board of directors of Bank $B$.

\section{E. Changes in Banking Competition and Practice Resulting from the Merger}

On June 2, 1958 the merger between the two banks becane effective. The only change in the local banking structure which resulted from the merger was the ellmination of one bank. Bank A remained the second largest bank in the county, and at the end of 1958, Bank A had increased its market share from 24 per cent to 28 per cent of the total banking assets in the county.

The acquisition of Bank $B$ was the first branch office for Bank $A$, but by the end of 1960 Bank $A$ was operating a total of three branch offices in the metropolitan area. The other two branch offices were de novo branches which had been establi shed in sections of the city which had previously provided substantial business for Bank $A$, or were not being adequately served by a branch of a competing bank. In addition, the Comptroller of the Currency had approved an application for a fourth branch office of Bant. A which they expected to have in operation by the aidale of 1961. This office will also be a de novo branch.

In discussing the merger with the President of Bank $A$ he curmmented that the merger had produced two major changes in the operation of his bank. First, Bank A had become a much more serious 
competitor for the largest bank in the county and this improved the local banking structure and had been of benefit to the public. Second, it was his opinion that the operation of Bank $A$ was better diversified than it had been previous to the merger. The introduction of the branches permitted Bank $A$ to engage more extensively in retail banking. As a result, a greater proportion of the total deposits are personal deposits, and a larger proportion of the total loans are consumer and residential real estate loans. By dividing the business of the bank between wholesale and retall banking the deposits and loans of the bank are auch more stable and affected much less by cyclical changes in the econony.

The President pointed out that the management of Bank $A$ had encountered one major disadvantage and one major advantage in being the last large bank in the community to establish branch offices. The major disadvantage they had encountered was the fact that many of the cholce locations for a branch office had already been acquired by the other banks and the savings and loan associations in the comminity. The primary advantage gained in being late to enter branch banking was the fact that they were able to benefit from the rl stakes that other banks had made in establishing their branch offices. As an example, a vice president of Bant $A$ is placed in charge of each branch office. Instead of appointing a branch manager who has Ifmited authority and must refer much of his business to the main office, Bank $A$ pernits the vice president in charge of each branch to operate nearly a full service bank, and if a customer 
requests a service which the branch ordinarily does not handle, a spectallst from the main office is sent to the branch office rather than sending the customer to the main office. The President of Bank $A$ stated that as a result of this pollcy they have been able to attract many customers away from branch offlces of other banks. He polnted out that this policy had special appeal for businessmen operating in the suburbs who want to carry on all banking transactions at the branch office.

A number of interviews with businessmen and individuals connected with the banking industry were held in order to solicit their opinions concerning the advantages and disadvantages which had resulted from the subject merger. The opinions expressed by these indivlduals were qulte sinilar. They all expressed pleasure over the fact that Bank $A$ was becouing a stronger competitor for the largest bank in the conmunity. Many polnted out that all three of the largest banks in the county are competing aggressively, and the public is the beneficiary of the competition. In addition, many referred to the aggressive managenent which the savings and loan assoclations are providing.

A few comnented that Bank $B$ could have contInued as an Independent bank had the managenent of the bank been wiling to establish branch offices and offer a broader line of banking services. They added, however, that the branch offlce of Bank A offered more services than Bank $B$ had offered its customers. 
Mearly all of those interviewed emphasized that prior to the eerger, Bank $A$ had been unresponsive to the banking needs of the public. Many were of the opinion that with the establishment of branch offices and a broader line of banking services that Bank $A$ could more than recover the share of the banking market which it lost during the postwar period. In general, all of those interviewed seemed to agree that the merger had improved the banking structure rather than danaged $1 t$.

\section{Sumary}

In each of the bank combinations previously examined the econonic base of the banking community, location of the affected banks, size of the banks, neans of accomplishing the combination, and the basic causes of the combination differed. There were, however, definite sinllarities between the three cases, and an analysis of those sinilaritles provides a better understanding of the bank combination movement.

In each of the cases an analysis of the causes of the combination reveals that there were basic econonlc changes in the communlty and the banking market which created a need for the comblnation. In each of the cases the demand for additional banking services played a role in bringing about the comblnation. In one case the rapld grouth and expansion of industrial and comerclal enterprises resulted in a need for a larger bank in the communt ty which was finally provided by a consolidation. In each of the $c$ ases discussed 
the desire to compete more vigorously with other banks and financial institutions served as an influencing factor. In two of the cases the fallure to train or attract successor management played an important part in the desire to combine with another bank. In two of the three cases the opportunity to operate on a larger scale and thereby reduce the operating costs served as an inducement to comblne. In not one of the cases was there any evidence that the combination had been undertaken in an effort to secure a monopolistic position in the banking market, or to force a competitor out of the market. Nor was there any evidence in any of the cases that the combinations had been undertaken in order to gain an objective that would be disadvantageous to the general public. In short, none of the Insldious purposes so often assigned to postwar bank consolldations and mergers by those testifying before Congressional conaittees was found as a motivating factor in the three combinations which were studied. Furthermore, the purposes behind postwar bank combinations In Ohio are no different than the objectives of bank conbinations In other parts of the United States. This has been verified through a comparison of thi study with sinflar studies in other parts of the country.

In addition, interviews held with citizens of the communities In which the combinations took place revealed that the combinations had inproved the banking structure. The majority of those interviewed neasured the strengths and weaknesses of their respective banking 
structure by the desirablity of the services which the local banks made aval lable. In each of the cases nearly all of the Individuals interviewed placed particular emphasis upon the additional banking services and the improved quality of banking services that resulted from the combination. In general, the majority of those interviewed were of the oplaion that the bank combinations in their respective conmuntiles had provided a superior banking structure.

It is granted that the three bank combinations anaiyzed in this study do not provide a sufficient sample upon whlch to base conclusions concerning the entire postwar bank combination movement in the Unt ted States. The study does reveal, however, that many of the conclusions reached by Congressional comalttees concerning the causes and effects of bank combinations have been erroneous. The error results from the fallure to give adequate attention to the specific banks and communties involved in consolidations and mergers.

For this reason the abjectlons of the federal bank regulatory agencies to subjecting the banking industry to the antitrust laws and the regulation of the Department of Justice seem valid. A know1edge of the differences in bank magement and banking practices in the numerous local and reglonal banking markets does seem a necessary prerequisite for the agency or agencles assigned with the responsibilfty of approving applications for bank consolldatlons and mergers. 


\section{CHAPTER VII}

\section{SUMMARY AND CONCLUSIONS}

This dissertation is devoted to an analysis and evaluation of concentration in banking in Ohlo from 1945 to 1959 , and within its scope there are six objectives. The first of these is to deternine and evaluate the changes in the structure of baniking in Ohio between 1945 and 1959, and to focus spectal attention on those changes which have affected conpetition. Second, the study measures and analyzes the proportion of total bank resources held by the large netropolitan banks in Ohio during the postwar period. The third objective of the dissertation is to evaluate the nature of competition anong banks and between banks and nonbank financial Institutions in Ohio. Fourth, it provides an examination of the pattern of growth of branch banks and group banking, and evaluates the primary causes of their growth during the subject period. Fifth, the study considers the effect of bank consolidations and mergers on bank competition and concentration in Ohio during the postwar period, and 1t analyzes the methods employed by both federal and state governments in an attempt to control the postwar increase in bank comblnations. The sixth and last objective of the dissertation is an analysis of the underlying causes of bank consolldations and mergers in Ohio during the postwar perlod, and an evaluation of their effect on the local banking markets. 


\section{Sumary}

A. Changes in Banking Structure in Ohio

The years following World War II witnessed rapid changes in the banking structure of onlo. The most significant was the reduction in the number of unit banks and the rapld expanst on in the number of branch banks. The largest decline in the muber of unit banks was anong state chartered banks while naticnal banks provided the largest increase in branch offices anong all banks in Ohio. As a result, during the postwar period national banks in Ohio increased the percentage of total banks and banking offices under thelr control; however, state banks continued to account for the largest number of banks and banking offices in Oh1o throughout the subject perlod.

The total resources of all banks in Ohio changed both in quantity and composition during the postwar perlod. The total bank assets in ohio expanded by 55.5 per cent between 1945 and 1959, and the composition of bank assets changed from predoninantly United States government obligations in 1945 to loans and discounts in 1959. The largest increase in loans and discounts of all banks in ohfo occurred in consuner and real estate loans. Despite the fact that national banks in Ohio were fewer in number than state banks throughout the subject period, by 1959 national banks controlled the majority of bank resources in Onfo, and in 1959 the average asset size of national bants in Ohio exceeded the average asset size of state banks by 37.1 per cent. 
The change in the composition of bank assets was also reflected in the total operating income of banks in Ohio. In $1945,52.3$ per cent of the total operating incone of all banks in Onio was derived from investments in securities, but by 1959 the proportion of operating income galned from this source had declined to 28.4 per cent. During the sane period the Income acquired from loans and discounts of banks in Ohlo Increased fron 29.9 per cent to 57.3 per cent of total operating income.

The grourth in income from loans and discounts also resulted from the higher yields aval lable on loans, princlpally consuner and real estate loans, as compared to the yield on securlties held by banks. The result was that the banking structure changed to facilitate the making of loans and to attract additional deposits.

\section{B. Concentration and Conpetition} In Banking in Chio

An analysis of the 20 largest banks in Ohio revealed that throughout the postwar period these banks controlled more than 58 per cent of the total bank resources in Ohlo, but there was no increase In the proportion of total resources under their control during this period. On the other hand, the proportion of total bank resources in Ohio held by the 10 largest banks declined slightly from 46.29 per cent in 1945 to 45.45 in 1959, and the largest bank in Ohio controlled 11.96 per cent of the total bank assets in the state in 1959, whereas In 1945 , 14.20 per cent of the total bank resources in Ohio were held by the largest bank. 
The 20 largest banks in Oh10 in 1945 and in 1959 were all located in the elght netropolitan counties, and in order to determine the extent of geographic concentration of bank resources in Ohio, the assets of the 20 largest banks were combined with all other banks operating in the metropolitan counties. This analysis revealed that the banks in the elght metropolitan counties accounted for approximately 70 per cent of the total banks resources in Onio at the beginning and at the end of the subject period.

In order to compare the extent of bank concentration in Ohio in 1959 with the rest of the United States, the concentration of assets of all insured banks in Ohio was compared with the concentram tion of assets anong all insured banks in the Unfted States. The investigation revealed that Ohio had less concentration of bank assets in 1959 than the balance of the nation.

The postwar decline in the number of unit banks in onio and the increase in bank assets resulted in a substantial increase in the average size of the remaining banks. Another prinary cause of Increased bank size was the realization by bank management of the econonles and competi tive advantages of a larger operating bese. Operating ratios for Federal Reserve nenber banks in Ohio in 1959 Indicate that the banks with total deposits of more than $\$ 50 \mathrm{milli}$ on were more profitable in terms of net profit to total capital aecounts than those with deposits of less than $\mathbf{5 0}$ million. Analysis of the operating ratios of the various sizes of meaber banks in 1959 alse disclosed that econonies of scale re not present at all levels of 
deposit growth. The immediate result of rapid growth of deposits appears to be an increased ratio of operating costs to gross income, but over a period of time the influence of growth is to reduce the ratio of operating costs to gross income as the operating base of the bank continues to expand and the cost advantages of larger scale operations are encountered.

Another reason for bank managenent's desire to acquire a larger operating base during the postwar perfod was the nature of the compet1tion anong banks and between banks and nonbank financial institutions in Chio. It is generally conceded by banking authorities that competition in banking does not center around the charges made for loans and services. Extensive competition does exist among banks, however, in the number and quallty of services which are provided customers. During the postwar period banks in Ohio were also subjected to an increased anount of competition from nonbank financlal Institutions. These organizations, especially savings and loan assoclations, grew rapidly as a result of their ablitty and willingness to eet demands for financial services that the banks were el ther unable or unwliling to provide. As a result, the competition which these organizations provide for banks also centers around the number and quality of services offered customers. In order, therefore, to compete nore effectively with other banks and nonbank financlal institutions, banks in ohlo have found it necessary to offer new and superior services. These services, in turn, have increased the fixed operating costs of the respective banks and, in an effort to 
offset the increased costs, management has attempted to acquire a larger operating base over which the additional fixed costs may be distributed.

\section{Branch and Group Banking in Ohio}

During the period 1945 to 1959 , there were 437 additional branch banks placed in operation in Ohio. The primary reason for the rapid growth in branch banking was the shift in exphasis from a primarily wholesale banking business to a combination of both wholesale and retail banking. Retal 1 banking requires that the banking offices be readily accessible to the consumer for both deposit and loan purposes. During the postwar perlod consuners and many businesses began to move from the cities to the outlying suburban areas. In an effort to retain the business of the industrial and commercial enterprises moving to the suburbs and to attract the business of the consumer, banks began to establish branch offices in the suburbs. These branches were established by absorbing existing banks or creating de novo branches. In many instances, the branch of an existing bank has proved to be a more efficlent and desirable method of serving the banking needs of small communitles and newly establl shed suburbs than small unft banks.

During the postwar perlod there was a substantial decline in the percentage of total branch banks in Ohio controlled by the large metropolitan banks. From 1945 to 1959 the proportion of total branch offices in Ohio under the control of the 20 largest metropolitan benks 
declined from approximately 75 per cent to 49 per cent, and the proportion of total branch banks operated by all banks located in the eight metropolitan countles declined from approximately 86 to 62 per cent of the total number of branch banks in the state during the same period.

The Ohio law which 1 imlts the operation of branch bank offices to the same county in which the parent bank is located is the primary reason for the reduction in the concentration of banking offices in the metropolltan counties of chio. This law applies to both national and state chartered banks.

The federal law requires that all national banks comply with the laws concerning geographical $11 \mathrm{mltati}$ ons on branch banking of the state in which they are located.

The large metropolitan banks in Ohlo establl shed numerous branch offices prior to 1945, and as a result of the restrictions placed on branch operations by Ohio law, the postwar opportunlties for additional branch operations for the banks located in the elght metropolftan countles were somewhat 1 imited. On the other hand, the banks located In other parts of Ohio generally did not adopt branch operations until after the end of World War II, and there were numerous opportunitles for additional offices in wany of the nometropolitan counties.

The bank holding coupany or group banking serves as a convenlent device for circumventing the geographical restrictions placed on branch banking by Ohlo law. Through the holding company device Individual banks become reglonal branches of the dominant or key bank 
in the group. Ohio law is silent on the operation of bank holding companies, and federal law permits the operation of statewide and, in some instances, interstate group banking. During the entire postwar period there were three bank holding companies in operation in Onio, and by 1959 two remained in operation. The largest and the oldest of the holding companies is the Banconio Corporation. In 1959, the Bancohio Corporation had 22 affillated banks operating 51 banking offices in 20 Ohio counties. The total assets of the 20 banks accounted for nearly six per cent of the total bank resources in Ohio. The dominant or key bank in the Bancohio group is the onio National Bank in Columbus, which in 1959, accounted for approximately 62 per cent of the total assets of the entire group.

\section{Bank Consolidations and Mergers in Ohio}

During the 14-year period following the end of World War II Ohfo had the fourth highest muber of bank consolidations and mergers among the 48 states. Between 1945 and 1959 there were 106 banks absorbed in Ohio. An analysis of the absorbed banks revealed that they were predominantly swaller banks each with total assets of less than $\$ 25 \mathrm{~m} 1111 \mathrm{on}$, and approximately 64 per cent of the absorbed banks each had assets of $\$ 5$ alllion or less. In contrast to the opini on of any people concerning the dominance of large banks in postwar bank consolidations and mergers, an a nalysis of acquiring banks in Ohio during the subject period revealed that over 62 per cent of the acquiring banks each had total resources of $\$ 50$ million or 
1ess. On the other hand, the banks in Ohio with resources of $\$ 100$ million or more vere responsible for only 29 per cent of the acquisitions during the same perlod.

The information acquired from selected case studies of postwar bank consolidations and mergers in ohio and a survey of current banking 11terature revealed that the postwar bank combination novement resulted primarily from attempts of the banking industry to adapt itself to the various economic changes in particular communities and to meet the demands of banking customers, rather than from a consclous effort to elininate competition and secure greater concentration of banking resources.

Some of the more important causes of bank consolldations and mergers during the postwar period have been: (1) the advantage of establishing a branch bank by absorbing an existing bank rather than forming a de novo branch; (2) small bank shareholders desire to el ther recelve a falt cash value for their stock or exchange their shares for those of a larger bank which offers increased marketablifty and a more attractive yield; (3) the problem of attracting capable successor anagement in the small rural bank; (4) the growth of business enterprises during the postwar period which has resulted in the deand for larger loans and lines of credlt from the banks which service these organizations; (5) the desire on the part of many banks to increase or retain their market position and diversify their operations; and (6) the inabllity of many small banks to earn an adequate rate of return on investment. 
During the postwar period one of the most publicized problems of banking was the Congressional effort to pass legislation to deal more effectively with bank consolldations and mergers. The antitrust laws have been of $1 \mathrm{fmited}$ usefulness against banking comm binations. The Sherman Antitrust Act has been exployed only once in the field of banking, and in that case the action was directed by the Department of Justice to block acquisition of The California Bank of Los Angeles by the Firstamerica Corporation. The Department of Justice, however, agreed to drop the case after an agreement was reached with the Firstamerfca Corporation, and as a result the Sherman Ant1trust Act has never been fully tested agalnst banking combinations. The Clayton Act has also been of little value in attempting to block bank consolidations and mergers. The origlnal sectlon 7 of the Clayton Act prohibited only combinations accomplished through stock acquisition if they resulted in a substantial lessening of competition, but bank combinations are usually accompllshed through asset acquisition. The 1950 amendment to the Clayton Act made the law applicable to asset acquisitions as well as stock acqui sitions, but banks are specifically exempt from the 1950 amendment.

The regulation of bank consolidations and mergers throughout the postwar perlod has been under the supervision of the Comptroller of the Currency, the Federal Deposit Insurance Corporation, the Federal Reserve Board of Governors, and the varlous state banking authorities. Attempts have been made, however, throughout the subject period to Introduce leglslation which would give the Department of 
Justice authority to el ther approve or disapprove proposed benk comblnations, and to make the antitrust laws fully applicable to the banking industry. The aforementioned federal and state bank regulatory agencies have argued, however, that banking is a highly specialized field which requires a substantial anount of fanilfarity with banking structure and bank operating pollcles before a sound decision can be reached concerning the merits of a proposed consolidation or merger. The case studies of postwar bank consolidations and mergers in Ohto also provided a substantlal amount of evidence concerning the importance of analyzing and understanding the local economy and banking conditions before passing fudgaent on the effects of a proposed bank combination.

In 1960 , legislation was passed by the $U$. $\mathbf{s}$. Congress which broadened the powers of the Comptroller of the Currency, Federal Deposit Insurance Corporation, and the Federal Reserve Board of Governors with regard to the control of bank mergers and consolidations, and the legislation provided that the ultimate responsiblilty for approving bank combinations rearains under the control of these three agencles. The new law stipulated, however, that each of the three agencies, the Comptroller of the Currency, the Federal Deposit Insurance Corporation, and the Federal Reserve Board of Governors, must give specific consideration to the competitive effects of any proposed combination under their respective furisdictions. In addition, each of the three aforenentioned agencies nust soliclt the opinion of the other two agencies and also the opini on of the 
Attorney General of the United States concerning the effect upon competition of any proposed bank combination under their respective furisdictions. The law does not stipulate, however, that any of the three federal bank regulatory agencies are obliged to heed the oplnion of el ther of the other two agencfes or the Attorney General in electing whether or not to approve a proposed combl nation.

The Department of Justice, which advocated that the antitrust laws be applied to the banking industry, was not satisfied with the new legislation, and at the present writing the Attorney General is attempting to block several bank comblnations which were approved by the three federal bank regulatory agencies after the passage of the 1960 law. The Attorney General has brought sult against the particlpating banks on grounds that the combinations would be in violation of the antitrust laws. The final decision as to who will exercise approval over bank consolidations and mergers will be made by the courts.

\section{E. Case Studies of Postwar Bank Consolidations and Mergers In Ohio}

In order to gain a better understanding of the causes and consequences of bank consolidations and mergers in Ohio, a series of carefully selected case studies were conducted. In selecting the cases an attempt was made to choose combinations that vould provide (1) econoulc and geographlc diversiffcation, (2) a sample of both large and sall banks in Ohio, (3) an example of both state and national chartered banks, and (4) 11lustrations of the three prinary 
methods of carrying out a bank comblnation. After selecting a large sample of bank combinations which took place between 1955 and 1958, Interviews were held with the Ohio Superintendent of Banks, and offlcers of the Federal Reserve Bank of Cleveland, the Federal Deposit Insurance Corporation, and the Ohio Bankers Association. With the help of these individuals the original sample was narrowed to three case studies which in their opini on provided a good sample of postwar bank combinations in Ohio.

Each case study was conducted by holding an extended interview with the president of the resulting bank regarding the primary notives behind the combination, the means by which the combination was carried out, and the advantages or di sadvantages which resulted from the combination. Following the interview with the bank president, a number of interviews were held with residents and businessmen of the respective communitles to sollcft their opinions concerning the advantages which their communitles and businesses had received as a result of the bank combination. In addition, interviews were held with local businessmen and officers of local chambers of commerce to acquire information regarding the economic base of the banking commities.

In each of the case studies the prinary reasons for the bank combinations stemed from fundamental changes in the local econony, the community, the needs of the bank's customers, and in the management polfcies of the subject banks. In not one of the cases was there any indication that the purpose of the combination was an 
attempt to gain an abjectl ve that would have been to the disadvantage of the general public and the banking community. In interviews with local residents and businessmen, nearly all stated that the bank combination had provided the communtty with wore efficient and desirable banking service. In two of the three cases it was the opinion of a najority of those interviewed that the combination resulted in Increasing competition among the local banks and between the banks and nonbank flnancial Institutions.

\section{Conclusions}

Throughout the postwar period the 20 largest banks in Ohlo accounted for approximately 60 per cent of the total bank assets in the state. It has been asserted that as a result of the decline in the number of unit banks and the rapid increase in the number of branch banks in Ohlo during the postwar perlod, the large banks increased the proportion of bank resources which they controlled in the state and, therefore, that competition in banking in onlo decreased during the subject period. The results of this study indlcate, however, that there was no increase in bank concentration in Onio during the period 1945 to 1959. Furthermore, the study revealed that the proportion of total banking offices in anio under the control of the largest benks declined between 1945 and 1959, and this fact lends support to the proposition that bank competition in Ohfo increased during the subject period. 
The mistaken idea that competition in banking in Ohio decreased between 1945 and 1959 resulted from attempts to measure the extent of competition in the banking market by counting the number of banks in operation. This method of neasuring competition can be quite misleading. For example, if the number of banks in a cormunity is reduced from six to three, is competition increased or decreased if the result is three strong banks rather than six weak banks? If a community at an earlier date had two banks and now has in their places two branches each of a different bank, is the banking competition in the community reduced?

The fact that banking is a partially regulated industry also linlts attempts to measure bank competition on the basis of the mumber of banks in operation. The bank regulatory agencies have recognlzed the need for 1 imitations on the number of banks in operation in order to make certain that the banking structure is not weakened by an excessive number of small and poorly managed banks as existed between 1921 and 1934. To prevent a recurrence of these conditions the bank regulatory agencles have insisted that certain standards be met prior to the is suance of a bank charter, and they have refused to issue charters for new banks in conmunities where, in the opinion of the regulatory agencies, a sufficient number of banks are already in operation.

Another oversight on the part of those who attempt to measure bank competition by counting the number of banks in operation is the 
failure to consider the growing importance of nonbank financial institutions as a source of competition for banks.

In the volumes of testimony before various Congressional committees throughout the postwar period regarding concentration and competition in commercial banking, the Comptroller of the Currency, the Federal Deposit Insurance Corporation, the Federal Reserve Board of Governors, and the various state banking agencies insisted upon using a more sultable measure of competition in banking than merely counting the number of banks in operation. If adequate regulation of banking is to be maintained and sound leglslation provided, a more scientific method of measuring competition must be utflized. Unfortunately, the Department of Justice has shown reluctance to use any method of determining competition other than counting the number of competitors and measuring market shares. The Department of Justice a1so seems unwiling to consider the local economic conditions and the condition of the participating banks when attempting to judge the desirability of a proposed bank consolidation or merger. The best way, therefore, to assure that a competitive, but strong banking structure is maintained is to allow the regulation of bank combinations to remain under the furlsdiction of the aforementioned federal and state bank regulatory agencies.

With the continued growth of Ohio's econony and its metropolItan communities there is adequate reason to believe that more independent banks in Ohfo will be replaced by branch offices of other banks. Much of the postwar growth in branch banking in Ohio was in 
response to the migration of people and business enterprises from the cities to the suburbs. It is expected that this migration will continue, and as the peripheries of Ohio's metropolitan areas continue to expand, they will extend beyond the boundaries of the county in which the center of the metropolitan area is located. At present, however, the banks in ohio are not allowed to operate branch offices outside the county in which the main office is located. In anticipation of the continued mi gration of people and businesses to the suburbs it would seem advisable to liberallze the banking law of Ohio to permit branch banking across county lines where metropolltan areas and trade areas exceed the boundaries of a single county. Otherwise, as the metropolitan and trade areas expand beyond the county lines, the problem of serving these areas with adequate banking facilities may become a major banking problem.

At the same time, group banking in Ohlo should be restricted to intracounty operations with the exception of metropolitan and trade areas that extend beyond the boundarles of a single county. This would eliminate the present inconsistency which exists in the regulation of muliple office banking in Ohio.

In conclusion, the evidence resulting from this study clearly indicates that, during the period from 1945 to 1959, Ohio had a strong and competitive banking structure. To assure that the system remains responsive to the banking needs of Ohio, however, 
proper regulation and control must be maintained, but restrictions must not be Imposed which prevent the banking structure from adapting itself to changes in the economy and to the banking needs of the state. 
APPENDIX

\section{5}


TABLE 41

Number of Unincorporated Banks in Operation in Ohio 1945-1959

(Thousands of Dollars)

\begin{tabular}{ccc}
\hline Year & Number In & Total Assets \\
\hline 1945 & 7 & 5,939 \\
1946 & 7 & 6,697 \\
1947 & 7 & 6,640 \\
1948 & 6 & 5,979 \\
1949 & 6 & 6,181 \\
1950 & 5 & 5,720 \\
1951 & 4 & 5,131 \\
1952 & 4 & 5,438 \\
1953 & 3 & 2,953 \\
1954 & 2 & 1,193 \\
1955 & 1 & 836 \\
1956 & - & - \\
1957 & - & - \\
1958 & - & - \\
1959 & - & - \\
\hline
\end{tabular}

Source: Annual Reports of the Comptroller of the Currency, 1946-1960. 
TABLE 42

LOCATION OF MATIONAL AND STATE BANKS IN OHIO

BY COUNTY

1945-1959

\begin{tabular}{|c|c|c|c|c|c|c|}
\hline \multirow{2}{*}{ County } & \multicolumn{3}{|c|}{1945} & \multicolumn{3}{|c|}{1959} \\
\hline & Nat Ional & State & Total & Jat Ional & State & Total \\
\hline Adans & 2 & 3 & 5 & 2 & 3 & 5 \\
\hline Allen & 3 & 3 & 6 & 3 & 2 & 5 \\
\hline Ashland & 1 & 4 & 5 & 1 & 4 & 5 \\
\hline Ashtabula & 2 & 9 & 11 & 1 & 7 & 8 \\
\hline Athens & 4 & 3 & 7 & 4 & 4 & 8 \\
\hline Auglai ze & 2 & 3 & 5 & 3 & 4 & 7 \\
\hline Beimont & 8 & 4 & 12 & 7 & 4 & 11 \\
\hline Broun & 5 & 3 & 8 & 6 & 3 & 9 \\
\hline But1er & 4 & 4 & 8 & 6 & 3 & 9 \\
\hline Carrol1 & 2 & 2 & 3 & 1 & 2 & 3 \\
\hline Champaign & 3 & 4 & 7 & 2 & 3 & 5 \\
\hline Clark & 3 & 3 & 6 & 3 & 4 & $?$ \\
\hline Clermont & 5 & 4 & 9 & 4 & 4 & 8 \\
\hline Clinton & 4 & 3 & 7 & 4 & 2 & 6 \\
\hline Columbl ana & 3 & $\overline{8}$ & 11 & 4 & 7 & 11 \\
\hline Coshocton & 2 & 1 & 3 & 2 & 1 & 3 \\
\hline Crawford & 2 & 5 & 7 & 2 & 6 & $\overline{8}$ \\
\hline Curahoga & 3 & 8 & 11 & 3 & 5 & 8 \\
\hline Darke & 5 & 7 & 12 & 4 & 7 & 11 \\
\hline Defi ance & $=$ & 3 & 3 & - & 4 & 4 \\
\hline Delavare & 1 & 4 & 5 & 1 & 5 & 6 \\
\hline Erie & 1 & 5 & 6 & 1 & 5 & 6 \\
\hline Falrfield & 4 & 9 & 13 & 3 & 7 & 10 \\
\hline Fayette & 2 & 3 & 5 & 1 & 3 & 4 \\
\hline Franklin & 4 & 13 & 17 & 4 & 12 & 16 \\
\hline Fulton & - & 6 & 6 & - & 6 & 6 \\
\hline Gallia & 1 & 3 & 4 & 1 & 2 & 3 \\
\hline Geauga & 1 & 2 & 3 & 2 & 2 & 4 \\
\hline Greene & 3 & 2 & 5 & 3 & 3 & 6 \\
\hline Guernsey & 4 & 3 & 7 & 3 & 1 & 4 \\
\hline Hall 1 ton & 10 & 18 & 28 & 4 & 7 & 11 \\
\hline Hancock & 1 & 4 & 5 & $\overrightarrow{1}$ & $\dot{4}$ & 5 \\
\hline Hardin & 4 & 5 & 9 & 4 & 3 & 7 \\
\hline Harri son & 2 & 3 & 5 & 3 & 2 & 5 \\
\hline Henry & - & 6 & 6 & - & 6 & 6 \\
\hline
\end{tabular}


TABLE 42 (continued)

\begin{tabular}{|c|c|c|c|c|c|c|}
\hline \multirow{2}{*}{ County } & \multicolumn{3}{|c|}{1945} & \multicolumn{3}{|c|}{1959} \\
\hline & Bational & State & Total & Iational & State & Total \\
\hline HI ghland & 3 & 3 & 6 & 3 & 3 & 6 \\
\hline Hocking & - & 2 & 2 & - & 2 & 2 \\
\hline Holnes & - & 3 & 3 & - & 4 & 4 \\
\hline Hur on & 2 & 6 & 8 & 3 & 6 & 9 \\
\hline Jackson & 2 & 3 & 7 & 2 & 2 & 4 \\
\hline Jefferson & 5 & 7 & 12 & 4 & 6 & 10 \\
\hline Knox & 1 & 5 & 6 & 1 & 4 & 5 \\
\hline Lake & - & 1 & 1 & 1 & 2 & 3 \\
\hline Lawrence & 2 & $=$ & 2 & 2 & 1 & 3 \\
\hline Licking & 3 & 9 & 12 & 3 & 7 & 10 \\
\hline Logan & 1 & 8 & 9 & 1 & 8 & 9 \\
\hline Lorain & 1 & 11 & 12 & 1 & 9 & 10 \\
\hline Lucas & - & 10 & 10 & 1 & 6 & 7 \\
\hline Madi son & 3 & 2 & 5 & 3 & 2 & 5 \\
\hline Mahoning & 3 & 4 & 7 & 4 & 4 & 8 \\
\hline Marion & 2 & 4 & 6 & 2 & 2 & 4 \\
\hline Medi na & 2 & 6 & 8 & 2 & 5 & 7 \\
\hline Melgs & 3 & 2 & 5 & 3 & 2 & 5 \\
\hline Mercer & 2 & 6 & 8 & 2 & 6 & 8 \\
\hline Miani & 6 & - & 6 & 6 & 1 & 7 \\
\hline Monroe & 2 & - & 2 & 1 & - & 1 \\
\hline Montgomery & 6 & 10 & 16 & 6 & 6 & 12 \\
\hline Morgan & 5 & - & 5 & 5 & - & 5 \\
\hline Morrow & 1 & 2 & 3 & 1 & 1 & 2 \\
\hline Musk1 ngun & 2 & 1 & 3 & 2 & 1 & 3 \\
\hline Noble & 1 & 1 & 2 & 1 & 1 & 2 \\
\hline Ottawa & 2 & 5 & 7 & 2 & 5 & 7 \\
\hline Paulaing & 1 & 3 & 4 & 1 & 3 & 4 \\
\hline Perry & 1 & 7 & 8 & 1 & 7 & 8 \\
\hline PI ckaway & 4 & 3 & 7 & 5 & 4 & 9 \\
\hline Pike & 1 & 1 & 2 & 1 & 1 & 2 \\
\hline Portage & 4 & 3 & 7 & 3 & 3 & 6 \\
\hline Preble & $\overrightarrow{4}$ & 3 & 7 & 4 & 3 & 7 \\
\hline Putnani & 2 & 5 & 7 & 2 & 5 & 7 \\
\hline Richland & 3 & 6 & 9 & 2 & 4 & 6 \\
\hline
\end{tabular}


TABLE 42 (continued)

\begin{tabular}{|c|c|c|c|c|c|c|}
\hline County & Tational & $\frac{1945}{5+36}$ & Totgl & Thtionat & $\frac{1959}{5+9+0}$ & Tato \\
\hline $\begin{array}{l}\text { Ross } \\
\text { Sandusky } \\
\text { Scloto } \\
\text { Seneca } \\
\text { Shelby }\end{array}$ & $\begin{array}{l}3 \\
1 \\
2 \\
4 \\
3\end{array}$ & $\begin{array}{l}4 \\
9 \\
1 \\
8 \\
3\end{array}$ & $\begin{array}{r}7 \\
10 \\
3 \\
12 \\
6\end{array}$ & $\begin{array}{l}3 \\
1 \\
2 \\
4 \\
1\end{array}$ & $\begin{array}{l}4 \\
7 \\
1 \\
7 \\
3\end{array}$ & $\begin{array}{r}7 \\
8 \\
3 \\
11 \\
4\end{array}$ \\
\hline $\begin{array}{l}\text { Stark } \\
\text { Sumit } \\
\text { Trumbull } \\
\text { Tuscarawas } \\
\text { Uni on }\end{array}$ & $\begin{array}{l}4 \\
8 \\
3 \\
5 \\
1\end{array}$ & $\begin{array}{r}15 \\
8 \\
6 \\
12 \\
2\end{array}$ & $\begin{array}{r}19 \\
16 \\
9 \\
17 \\
3\end{array}$ & $\begin{array}{l}4 \\
1 \\
2 \\
3 \\
1\end{array}$ & $\begin{array}{r}10 \\
5 \\
5 \\
8 \\
2\end{array}$ & $\begin{array}{r}14 \\
6 \\
7 \\
11 \\
3\end{array}$ \\
\hline $\begin{array}{l}\text { Van Wert } \\
\text { Vinton } \\
\text { Warren } \\
\text { Washington } \\
\text { Wayne }\end{array}$ & $\begin{array}{l}2 \\
1 \\
4 \\
2 \\
3\end{array}$ & $\begin{array}{l}2 \\
- \\
1 \\
9 \\
9\end{array}$ & $\begin{array}{r}4 \\
1 \\
5 \\
9 \\
12\end{array}$ & $\begin{array}{l}2 \\
1 \\
4 \\
2 \\
5\end{array}$ & $\begin{array}{l}2 \\
0 \\
1 \\
6 \\
9\end{array}$ & $\begin{array}{r}4 \\
1 \\
5 \\
8 \\
14\end{array}$ \\
\hline $\begin{array}{l}\text { Wi } 11 \text { iams } \\
\text { Wood } \\
\text { Wyandot }\end{array}$ & $\begin{array}{l}3 \\
1 \\
2\end{array}$ & $\begin{array}{r}6 \\
13 \\
5\end{array}$ & $\begin{array}{r}9 \\
14 \\
7\end{array}$ & $\begin{array}{l}3 \\
1 \\
2\end{array}$ & $\begin{array}{r}6 \\
11\end{array}$ & $\begin{array}{r}9 \\
12 \\
6\end{array}$ \\
\hline Total & 24,0 & 437 & 677 & 222 & 366 & 588 \\
\hline
\end{tabular}

Source: American Bank Di rectory (Atlanta, Ga.: McFadden Business Publications, 1960) and Polk's Bankers Encyclopedin (Detrolt: Michigan: R. L. Polk and Co., Publishers, 1946). 
TABLE 43

TOTAL LOANS AND DISOONMTS OF ALI BANKS MATIONAL BANKS, AND STATE BANKS IN OHIO 1945-1959

(Thousands of Dollars)

\begin{tabular}{|c|c|c|c|}
\hline Year & $\begin{array}{c}\text { A11 } \\
\text { Banks }\end{array}$ & $\begin{array}{l}\text { Mational } \\
\text { Banks }\end{array}$ & $\begin{array}{l}\text { State } \\
\text { Banks }\end{array}$ \\
\hline 1945 & $\$ 1,292,405$ & 549,630 & 674,753 \\
\hline 1946 & $1,565,466$ & 649,244 & 832,789 \\
\hline 1947 & $1,869,712$ & 821,278 & 945,138 \\
\hline 1948 & $1,982,271$ & 873,645 & $1,003,668$ \\
\hline 1949 & $2,041,980$ & 886,792 & $1,053,499$ \\
\hline 1950 & $2,504,369$ & $1,084,020$ & $1,295,583$ \\
\hline 1951 & $2,770,628$ & $1,215,787$ & $1,418,745$ \\
\hline 1952 & $3,090,162$ & $1,375,339$ & $1,564,112$ \\
\hline 1953 & $3,382,046$ & $1,509,307$ & $1,701,564$ \\
\hline 1954 & $3,506,788$ & $1,556,418$ & $1,750,733$ \\
\hline 1955 & $4,090,056$ & $1,835,503$ & $2,047,871$ \\
\hline 1956 & $4,575,785$ & $2,070,440$ & $2,309,632$ \\
\hline 1957 & $4,821,064$ & $2,168,428$ & $2,455,976$ \\
\hline 1958 & $4,931,807$ & $2,224,974$ & $2,507,502$ \\
\hline 1959 & $5,434,698$ & $2,719,426$ & $2,700,911$ \\
\hline
\end{tabular}

Source: Anmual Report of the Comptroller of the Currency, 1946-1960. 
TABLE LU

COMPOSITION OF TOTAL LOANS AND DISCONNTS OF ALL BANKS IN OHIO 1945-1959

(Thousands of Dollars)

\begin{tabular}{|c|c|c|c|c|c|c|c|c|c|c|}
\hline Year & $\begin{array}{l}\text { Cowmerciel } \\
\text { and Indusm } \\
\text { trial Loans }\end{array}$ & $\begin{array}{l}\text { Per } \\
\text { cent } \\
\text { of } \\
\text { Total }\end{array}$ & $\begin{array}{l}\text { Loans to Brokers } \\
\text { and Dealers and } \\
\text { Other Loans for } \\
\text { the Purchese of } \\
\text { Securities }\end{array}$ & $\begin{array}{l}\text { Per } \\
\text { cent } \\
\text { of } \\
\text { Total }\end{array}$ & $\begin{array}{l}\text { Real Estate } \\
\text { Loans }\end{array}$ & $\begin{array}{l}\text { Per } \\
\text { cent } \\
\text { of } \\
\text { Total }\end{array}$ & $\begin{array}{c}\text { Other Loans } \\
\text { to } \\
\text { Indi viduals }\end{array}$ & $\begin{array}{l}\text { Per } \\
\text { cent } \\
\text { of } \\
\text { Total }\end{array}$ & $\begin{array}{l}\text { M11 } \\
\text { Other } \\
\text { Loans }\end{array}$ & $\begin{array}{l}\text { Per } \\
\text { cent } \\
\text { of } \\
\text { Total }\end{array}$ \\
\hline 1945 & 300,703 & 23.3 & * 373,319 & 28.7 & $\$ 374,339$ & 28.9 & 126,536 & 9.7 & $\$ 117,508$ & 9.4 \\
\hline 1946 & 499,819 & 31.9 & 177,160 & 11.3 & 536,189 & 34.3 & 214,135 & 13.7 & 138,173 & 9.8 \\
\hline 1947 & 621,772 & 33.3 & 129,974 & 7.0 & 686,292 & 36.7 & 342,836 & 18.3 & 88,838 & 4.7 \\
\hline 1948 & 641,323 & 32.0 & 83,587 & 4.2 & 775,529 & 38.7 & 396,559 & 19.7 & 85,273 & 5.4 \\
\hline 1949 & 585,009 & 28.2 & 106,262 & 5.1 & 819,455 & 39.5 & 444,231 & 21.5 & 87,023 & 5.7 \\
\hline 1950 & 758,273 & 29.8 & 145,075 & 6.0 & 940,935 & 37.0 & 561,813 & 22.1 & 98,263 & 5.1 \\
\hline 1951 & 898,403 & 31.9 & 112,136 & 3.9 & $1,047,562$ & 37.2 & 606,632 & 21.6 & 125,895 & 5.4 \\
\hline 1952 & 988,832 & 31.5 & $126,34,9$ & 4.0 & $1,150,616$ & 36.7 & 697,999 & 22.3 & 126,366 & 5.5 \\
\hline 1953 & 947,728 & 27.6 & 153,758 & 4.5 & $1,233,435$ & 35.9 & 835,219 & 24.4 & 211,856 & 7.6 \\
\hline 1954 & 894,564 & 25.1 & 211,118 & 5.9 & $1,362,758$ & 38.2 & 828,859 & 23.3 & 209,489 & 7.5 \\
\hline
\end{tabular}


TABLE L4 (continued)

\begin{tabular}{|c|c|c|c|c|c|c|c|c|c|c|c|}
\hline Year & $\begin{array}{l}\text { Conmercial } \\
\text { and Indus- } \\
\text { trial Loans }\end{array}$ & $\begin{array}{l}\text { Per } \\
\text { cent } \\
\text { of } \\
\text { Total }\end{array}$ & $\begin{array}{l}\text { Loans to Brokers } \\
\text { and Dealers and } \\
\text { Other Loans for } \\
\text { the Purchase of } \\
\text { Securities }\end{array}$ & $\begin{array}{l}\text { Per } \\
\text { cent } \\
\text { of } \\
\text { Total } \\
\end{array}$ & $\begin{array}{l}\text { Real Estate } \\
\text { Loans }\end{array}$ & $\begin{array}{l}\text { Per } \\
\text { cent } \\
\text { of } \\
\text { Total } \\
\end{array}$ & $\begin{array}{l}\text { Other Loans } \\
\text { to } \\
\text { Indi viduals }\end{array}$ & $\begin{array}{l}\text { Per } \\
\text { cent } \\
\text { of } \\
\text { Total } \\
\end{array}$ & & $\begin{array}{l}\text { All } \\
\text { Other } \\
\text { Loans }\end{array}$ & $\begin{array}{l}\text { Per } \\
\text { cent } \\
\text { of } \\
\text { Total } \\
\end{array}$ \\
\hline 1955 & $\$ 1,109,133$ & 26.7 & I 283,461 & 6.8 & $\$ 1,457,403$ & 37.2 & 962,990 & 23.2 & $\$$ & 278,069 & 6.1 \\
\hline 1956 & $1,109,133$ & 28.7 & 286,270 & 6.1 & $1,678,127$ & 36.0 & $1,222,171$ & 24.1 & & 380,084 & 5.1 \\
\hline 1957 & $1,419,899$ & 28.9 & 304,624 & 6.2 & $1,735,734$ & 35.3 & $1,199,666$ & 24.4 & & 161,141 & 5.2 \\
\hline 1958 & $1,383,307$ & 27.5 & 311,162 & 6.2 & $1,848,772$ & 36.3 & $1,196,443$ & 23.8 & & 192,823 & 6.2 \\
\hline 1959 & $1,358,609$ & 27.2 & 312,513 & 5.8 & $1,948,559$ & 33.3 & $1,196,443$ & 23.0 & & $1,618,574$ & 10.7 \\
\hline
\end{tabular}

Source: Annual Report of the Comptroller of the Currency, 1946-1960. 
TABLE 45

COMPOSITION OF TOTAL CAPITAL OF ALL BANKS IN OHIO 1945-1959

(Thousands of Dollars)

\begin{tabular}{rrrrrrrrrr}
\hline Year & $\begin{array}{c}\text { Capital } \\
\text { Stock }\end{array}$ & $\begin{array}{c}\text { Per cent } \\
\text { of } \\
\text { Total }\end{array}$ & $\begin{array}{c}\text { Notes and } \\
\text { Debentures }\end{array}$ & $\begin{array}{c}\text { Per cent } \\
\text { of } \\
\text { Total }\end{array}$ & $\begin{array}{c}\text { Undivided } \\
\text { Profit }\end{array}$ & $\begin{array}{c}\text { Per cent } \\
\text { of } \\
\text { Total }\end{array}$ & Reserves & $\begin{array}{c}\text { Per cent } \\
\text { of } \\
\text { Total }\end{array}$ \\
\hline 1945 & $\$ 148,599$ & 36.6 & $\$ 14,138$ & 3.4 & 50,121 & 12.2 & 27,189 & 7.8 \\
1946 & 153,013 & 35.2 & 9,872 & 2.3 & 59,804 & 13,8 & 27,191 & 6.3 \\
1947 & 158,013 & 34.8 & 6,267 & 1.3 & 67,245 & 14.6 & 22,920 & 5.8 \\
1948 & 160,217 & 34.3 & 896 & - & 75,608 & 16.3 & 17,494 & 3.8 \\
1949 & 159,980 & 33.3 & 780 & - & 80,227 & 16.9 & 17,200 & 3.5 \\
1950 & 161,855 & 31.0 & 728 & - & 86,888 & 16.8 & 17,436 & 3.8 \\
1951 & 176,199 & 30.9 & 474 & - & 96,501 & 17.0 & 13,723 & 3.0 \\
1952 & 188,205 & 31.1 & 1,013 & - & 103,792 & 17.2 & 13,984 & 2.6 \\
1953 & 195,805 & 30.5 & 865 & - & 116,629 & 18.2 & 8,692 & 2.5 \\
1954 & 205,120 & 29.8 & 165 & - & 355,762 & 16.8 & 8,802 & 1.5
\end{tabular}


TABLE 45 (continued)

\begin{tabular}{lrrrrrrrrrr}
\hline Year & $\begin{array}{c}\text { Capital } \\
\text { Stock }\end{array}$ & $\begin{array}{c}\text { Per cent } \\
\text { of } \\
\text { Total }\end{array}$ & $\begin{array}{c}\text { Motes and } \\
\text { Debentures }\end{array}$ & $\begin{array}{c}\text { Per cent } \\
\text { of } \\
\text { Total }\end{array}$ & $\begin{array}{c}\text { Undivided } \\
\text { Profit }\end{array}$ & $\begin{array}{c}\text { Per cent } \\
\text { of } \\
\text { Total }\end{array}$ & \multicolumn{2}{c}{$\begin{array}{c}\text { Per cent } \\
\text { of } \\
\text { Total }\end{array}$} \\
\hline 1955 & 219,387 & 30.1 & 160 & - & 375,884 & 16.6 & 9,288 & 2.2 \\
1956 & 232,808 & 29.8 & 110 & - & 118,810 & 15.1 & 8,194 & - \\
1957 & 252,733 & 29.8 & 100 & - & 131,731 & 15.5 & 8,489 & 1.2 \\
1958 & 259,028 & 29.6 & 100 & - & 148,451 & 16.9 & 6,812 & - \\
1959 & 288,972 & 30.2 & 100 & - & 168,228 & 17.5 & 6,692 & - \\
\hline
\end{tabular}

Source: Annual Report of the Comptroller of the Currency, 1946-1960 and Annual Report of the कilo Division of Banks, 1946-1960.

Yote: - Indicates less than 1.0 per cent. 
TABLE 46

TOTAL DIVIDENDS ON COMMON STOCK OF ALl BANKS IN OHIO 1945-1959

(Thousands of Dollars)

\begin{tabular}{lcc}
\hline Year & $\begin{array}{c}\text { Total Dividends on } \\
\text { Common Stock }\end{array}$ & $\begin{array}{c}\text { Dividends on Comon } \\
\text { Stock as a Per cent } \\
\text { of Total Het Income }\end{array}$ \\
\hline 1945 & 19,980 & 19.7 \\
1946 & 10,146 & 20.9 \\
1947 & 10,879 & 29.3 \\
1948 & 11,416 & 31.9 \\
1949 & 12,729 & 28.8 \\
1950 & 14,021 & 28.5 \\
1951 & 16,643 & 35.4 \\
1952 & 17,000 & 21.4 \\
1953 & 18,929 & 22.4 \\
1954 & 19,921 & 19.8 \\
1955 & $21,9.0$ & 24.6 \\
1956 & 24,218 & 23.4 \\
1957 & 27,166 & 21.9 \\
1958 & 28,532 & 20.3 \\
1959 & 30,442 & 26.3 \\
\hline
\end{tabular}

Source: How Does Your Bank Measure Up?, Ohfo Benkers Association, 1946-1960. 
TABLE 47

TOTAL ASSETS, DEPOSITS, AND CAPITAL OF THE 20 LAFGEST BANKS IN OHIO

December 31, 1945

(Thousands of Dollars)

\begin{tabular}{|c|c|c|c|c|c|c|c|c|c|c|c|}
\hline Nane of Bank & & $\begin{array}{l}\text { Totn1 } \\
\text { Assets }\end{array}$ & $\begin{array}{l}\text { Cash and } \\
\text { In Banks }\end{array}$ & & $\begin{array}{l}\text { S. Govt. } \\
\text { ecurl ities }\end{array}$ & $\begin{array}{r}\mathrm{T} \\
\text { Sec }\end{array}$ & $\begin{array}{l}\text { otal } \\
\text { urities }\end{array}$ & $\begin{array}{l}\text { Loans and } \\
\text { Di scounts }\end{array}$ & $\begin{array}{l}\text { Total } \\
\text { Deposits }\end{array}$ & & $\begin{array}{l}\text { Total } \\
\text { apital }\end{array}$ \\
\hline Cleveland Trust Company & & $1,111,815$ & \$ 166,442 & $\$$ & 682,305 & $\$$ & 21,172 & 234,765 & $\$ 1,052,730$ & $\$$ & 47,509 \\
\hline $\begin{array}{l}\text { Mational City Banik of } \\
\text { Cleveland }\end{array}$ & & 499,362 & 96,808 & & 281,140 & & 12,230 & 105,622 & 471,161 & & 22,294 \\
\hline $\begin{array}{l}\text { Central Wational Bank } \\
\text { of Cleveland }\end{array}$ & & 415,563 & 76,579 & & 239,655 & & 2,735 & 89,828 & 392,329 & & 18,974 \\
\hline The Toledo Trust Company & & 284,412 & 49,878 & & 206,019 & & 2,056 & 24,194 & 272,747 & & 11,417 \\
\hline $\begin{array}{l}\text { Fifth Third Union Bank } \\
\text { of Cincinnati }\end{array}$ & & 280,935 & 60,995 & & 133,535 & & $\underline{18,182}$ & 63,662 & 262,457 & & 18,262 \\
\hline 5 Largest Baniks in Ohio & & $2,592,087$ & $\$ 450,702$ & $\$ 1$ & $1,542,654$ & $\$$ & 56,465 & $\$ 518,071$ & $\$ 2,451,424$ & $\$$ & 118,456 \\
\hline $\begin{array}{l}\text { First Mational Bank of } \\
\text { CIncinnati }\end{array}$ & $\$$ & 253,609 & $\$ 61,630$ & $\$$ & 105,763 & $\$$ & 3,392 & \& 80,842 & 234,741 & $\$$ & 17,838 \\
\hline $\begin{array}{l}\text { The Central Trust } \\
\text { Company of Cincinnat1 }\end{array}$ & & 215,170 & 47,699 & & 144,847 & & 240 & 20,939 & 205,395 & & 9,088 \\
\hline $\begin{array}{l}\text { The Chio liational Bank } \\
\text { of Columbus }\end{array}$ & & 207,015 & 58,802 & & 89,688 & & 20,287 & 39,876 & 198,554 & & 8,461 \\
\hline $\begin{array}{l}\text { The Soclety for Savings in } \\
\text { the City of Cleveland }\end{array}$ & & 198,106 & 16,439 & & 95,520 & & 20,844 & 63,158 & 184,803 & & 11,538 \\
\hline $\begin{array}{l}\text { The Winters Yational Bank } \\
\text { of Dayton }\end{array}$ & & 156,792 & 33,650 & & 110,643 & & 150 & 11,562 & 150,442 & & 5,429 \\
\hline 10 Largest Bahks in onlo & & $3,622,779$ & $\$ 668,922$ & 52 & $2,089,115$ & $\$$ & 101,378 & $\longdiv { 6 5 3 , 6 0 6 }$ & $\$ 3, \overline{434,359}$ & & $\overline{170,810}$ \\
\hline
\end{tabular}


TABLE 47 (conti nued)

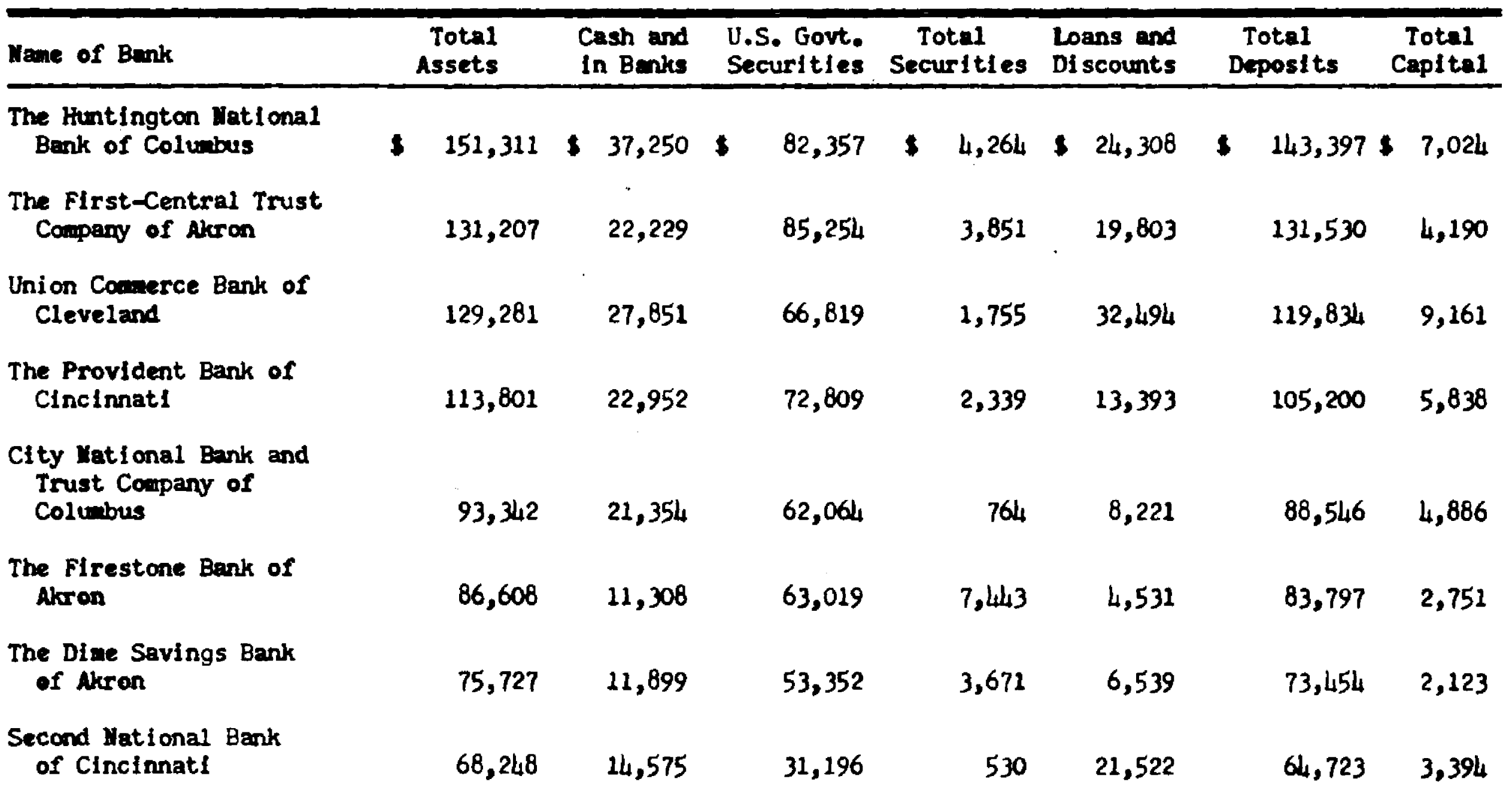


TABLE 47 (continued)

\begin{tabular}{|c|c|c|c|c|c|c|c|c|c|c|c|c|c|c|}
\hline \multirow[b]{2}{*}{$\begin{array}{l}\text { Union llational Bank of } \\
\text { Youngstown }\end{array}$} & \multicolumn{2}{|c|}{$\begin{array}{l}\text { Total } \\
\text { issets }\end{array}$} & \multicolumn{2}{|c|}{$\begin{array}{l}\text { Cash and } \\
\text { in Banks }\end{array}$} & \multicolumn{2}{|c|}{$\begin{array}{l}\text { U.S. Govt. } \\
\text { Securities }\end{array}$} & \multicolumn{2}{|c|}{$\begin{array}{c}\text { Total } \\
\text { Securities } \\
\end{array}$} & \multicolumn{2}{|c|}{$\begin{array}{l}\text { Loans and } \\
\text { Di scounts }\end{array}$} & \multicolumn{2}{|c|}{$\begin{array}{l}\text { Totel } \\
\text { Deposits }\end{array}$} & \multicolumn{2}{|c|}{$\begin{array}{c}\text { Total } \\
\text { Capital } \\
\end{array}$} \\
\hline & $\$$ & 67,935 & 8 & 14,224 & $\$$ & 41,072 & $\$$ & 5,905 & $\$$ & 5,036 & 3 & 62,971 & $\$$ & 4,647 \\
\hline $\begin{array}{l}\text { Third Mational Bank } \\
\text { and Trust Company } \\
\text { of Dayten }\end{array}$ & & 66,235 & & 12,106 & & 44,973 & & 1,176 & & 7,367 & & 63,655 & & 2,445 \\
\hline 20 Largest Bunks in Ohio & & 606,564 & & 864,671 & & 650,958 & & 33,076 & & 96,820 & & 371,466 & & 17,269 \\
\hline
\end{tabular}

Source: Moody's Bank and Finance Manual (New York: Moody's Investors Service, 19L6). 
TABLE 48

TOTAL ASSETS, DEPOSITS, AND CAPITAL OF THE 20 LARGEST BANKS IN CHIO

December 31, 1959

(Thousands of Do1lars)

\begin{tabular}{|c|c|c|c|c|c|c|c|c|c|c|c|c|c|}
\hline \multirow{2}{*}{$\frac{\text { Yane of Bank }}{\text { Cleveland Trust Company }}$} & \multicolumn{2}{|r|}{$\begin{array}{l}\text { Tota1 } \\
\text { Assets }\end{array}$} & \multicolumn{2}{|c|}{$\begin{array}{l}\text { Cash and } \\
\text { in Banks }\end{array}$} & \multicolumn{2}{|c|}{$\begin{array}{l}\text { U.s. Govt. } \\
\text { Securities }\end{array}$} & \multicolumn{2}{|c|}{$\begin{array}{l}\text { Other } \\
\text { Securities }\end{array}$} & \multicolumn{2}{|c|}{$\begin{array}{l}\text { Loans and } \\
\text { D1 scounts }\end{array}$} & \multirow{2}{*}{$\frac{\substack{\text { Total } \\
\text { Deposits }}}{1,332,147}$} & \multirow{2}{*}{\multicolumn{2}{|c|}{$\frac{\begin{array}{c}\text { Total } \\
\text { Cop1tal }\end{array}}{\$ 116,218}$}} \\
\hline & & $1,457,548$ & $\$$ & 236,330 & $\$$ & 286,935 & $\$$ & 97,166 & $\$$ & 826,933 & & & \\
\hline $\begin{array}{l}\text { Yational City Bank of } \\
\text { Cleveland }\end{array}$ & & 823,526 & & 204,143 & & 166,524 & & 77,302 & & 364,441 & $74 h, 379$ & & 66,655 \\
\hline $\begin{array}{l}\text { Central Mational Bank of } \\
\text { Cleveland }\end{array}$ & & 614,806 & & 141,513 & & 140,264 & & 34,586 & & 289,313 & 559,887 & & 49,154 \\
\hline $\begin{array}{l}\text { First Hat lonal Bank of } \\
\text { Cincinnat1 }\end{array}$ & & 461,282 & & 106,493 & & 120,156 & & 10,902 & & 217,054 & 414,113 & & 40,459 \\
\hline $\begin{array}{l}\text { Ohlo Mational Bank of } \\
\text { Colubuse }\end{array}$ & & 450,203 & & 112,674 & & 128,095 & & 60,543 & & 145,166 & 414,348 & & 25,100 \\
\hline 5 Largest Banks in Ohio & & $3,830,364$ & $s$ & 801,153 & $\$$ & 842,334 & $\$$ & 280,499 & & $, 842,907$ & $\$ 3,464,874$ & & 297,586 \\
\hline $\begin{array}{l}\text { Soctety Mational Bank } \\
\text { of Cleveland }\end{array}$ & $\$$ & 421,113 & $\$$ & 45,799 & $\$$ & 100,769 & $\$$ & 43,900 & $\$$ & 222,441 & 386,463 & $\$$ & 31,000 \\
\hline $\begin{array}{l}\text { Fifth Third Union Irust } \\
\text { Company of Cincinnati }\end{array}$ & & 371,010 & & 95,553 & & 75,155 & & 14,253 & & 179,796 & 334,776 & & 31,790 \\
\hline Toledo Trust Conpany & & 330,103 & & 55,015 & & 159,049 & & 20,367 & & 93,612 & 306,297 & & 21,310 \\
\hline $\begin{array}{l}\text { Centrai Trust Company } \\
\text { of Cincinnati }\end{array}$ & & 312,834 & & 78,555 & & 60,859 & & 5,342 & & 163,327 & 283,129 & & 24,849 \\
\hline $\begin{array}{l}\text { Uni on Comerce Banis of } \\
\text { Cleveland }\end{array}$ & & 292,680 & & 74,975 & & 50,715 & & 18,489 & & 135,485 & 258,958 & & 30,206 \\
\hline 10 Largest Banks in Chio & & $5,535,104$ & $\$$ & $1,152,308$ & $\$ 1$ & $, 288,881$ & & 382,846 & & $, 637,568$ & $\$ 4,989,497$ & & 436,741 \\
\hline
\end{tabular}


TABLE 48 (continued)

\begin{tabular}{|c|c|c|c|c|c|c|c|c|c|c|}
\hline \multirow{2}{*}{$\begin{array}{l}\text { Nane of Bank } \\
\begin{array}{c}\text { First Matlonal Bank of } \\
\text { Akron }\end{array}\end{array}$} & \multicolumn{2}{|c|}{$\begin{array}{l}\text { Total } \\
\text { Ausets }\end{array}$} & \multicolumn{2}{|c|}{$\begin{array}{l}\text { Cash and } \\
\text { In Banks }\end{array}$} & \multicolumn{2}{|c|}{$\begin{array}{l}\text { U.S. Govt. } \\
\text { Securities }\end{array}$} & $\begin{array}{c}\text { Other } \\
\text { Securities }\end{array}$ & $\begin{array}{l}\text { Loans and } \\
\text { Di scounts }\end{array}$ & $\begin{array}{c}\text { Total } \\
\text { Deposits }\end{array}$ & $\begin{array}{l}\text { Total } \\
\text { Capl tal }\end{array}$ \\
\hline & $\$$ & 266,625 & $\$$ & 43,721 & $\$$ & 88,939 & $13,2 \mathrm{k} 6$ & 116,380 & 245,667 & $\$ 17,358$ \\
\hline $\begin{array}{l}\text { The WInters National Benk } \\
\text { and Trust Company of } \\
\text { Dayten }\end{array}$ & & 254,667 & & 52,924 & & 84,914 & 2,807 & 110,764 & 224,746 & 19,833 \\
\hline $\begin{array}{l}\text { The Huntington National } \\
\text { Bank of Columbus }\end{array}$ & & 220,590 & & 60,236 & & 71,195 & 11,465 & 73,882 & 192,567 & 18,478 \\
\hline $\begin{array}{l}\text { The Provident Bank of } \\
\text { Cincinnat I }\end{array}$ & & 161,911 & & 27,113 & & 54,607 & 16,227 & 60,614 & 148,215 & 12,086 \\
\hline $\begin{array}{l}\text { The City Uaticnal Bank } \\
\text { and Trust Company of } \\
\text { Columbus }\end{array}$ & & 144,298 & & 36,363 & & 61,349 & 779 & 42,700 & 133,393 & 10,400 \\
\hline $\begin{array}{l}\text { The Dollar Savings and } \\
\text { Trust Coampany of } \\
\text { Youngstown }\end{array}$ & & 123,042 & & 18,756 & & 49,601 & 5,996 & 46,853 & 114,714 & 7,304 \\
\hline $\begin{array}{l}\text { The Ohio Citizens Trust } \\
\text { Compeny of Tolede }\end{array}$ & & 117,711 & & 32,832 & & 28,902 & 7,314 & 47,706 & 110,055 & 7,716 \\
\hline $\begin{array}{l}\text { The Fitrestone Bank of } \\
\text { Akron }\end{array}$ & & 113,840 & & 15,898 & & 50,570 & 12,439 & 33,446 & 105,045 & 7,906 \\
\hline
\end{tabular}


TABLE 48 (continued)

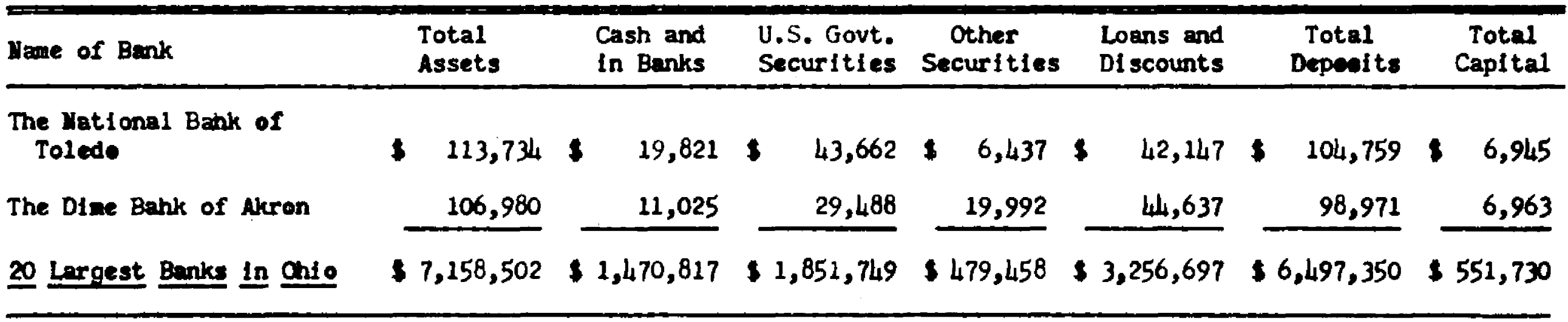

Source: Moody's Bank and Finance Mamual (New York: Moody's Investors Service, 1960). 
TABLE 49

ASSETS AND LIABILITIES OF ALL INSURED COMERCIAL BANKS IY THE UNITED STATES GROUPED BY DEPOSIT SIZE June 10,1959

(Amounts in Thousends of Dollars)

\begin{tabular}{|c|c|c|c|c|c|c|}
\hline $\begin{array}{l}\text { Depesit slze in } \\
\text { millons of } \\
\text { dollars }\end{array}$ & $\begin{array}{l}\text { Number of } \\
\text { Banks }\end{array}$ & $\begin{array}{l}\text { Cash and Due } \\
\text { from Banks }\end{array}$ & $\begin{array}{l}\text { U.S. Govt. } \\
\text { Obli gations }\end{array}$ & $\begin{array}{c}\text { Other } \\
\text { Securfities }\end{array}$ & $\begin{array}{l}\text { Loans, Di scounts } \\
\text { and Drafts }\end{array}$ & Total \\
\hline Less than 1 & 1,397 & 204,459 & 400,434 & 70,048 & 459,463 & $1,153,486$ \\
\hline 1 to 2 & 2,657 & 724,602 & $1,521,079$ & 357,360 & $1,743,338$ & $4,386,798$ \\
\hline 2 to 5 & 4,345 & $2,567,271$ & $5,166,240$ & $1,608,162$ & $6,107,010$ & $15,634,421$ \\
\hline 5 to 10 & 2,288 & $2,805,824$ & $5,552,167$ & $1,987,754$ & $6,976,956$ & $17,567,027$ \\
\hline 10 te 25 & $1,4,66$ & $3,914,998$ & $7,554,671$ & $2,570,759$ & $9,788,777$ & $24,321,533$ \\
\hline 25 to 50 & 462 & $2,754,426$ & $5,313,456$ & $1,727,153$ & $7,140,114$ & $17,24,9,607$ \\
\hline 50 to 100 & 224 & $2,977,096$ & $4,963,435$ & $1,739,449$ & $7,334,972$ & $17,332,659$ \\
\hline 100 to 250 & 151 & $5,059,282$ & $6,776,024$ & $2,132,558$ & $11,611,235$ & $26,077,340$ \\
\hline 250 to 500 & 60 & $4,988,985$ & $5,637,429$ & $1,804,276$ & $11,015,171$ & $23,915,216$ \\
\hline 500 te 1,000 & 28 & $4,366,061$ & $4,939,892$ & $1,689,585$ & $9,960,779$ & $21,991,073$ \\
\hline 1,000 or more & 19 & $12,314,352$ & $13,639,054$ & $4,697,881$ & $31,244,209$ & $63,549,435$ \\
\hline Total United States & 13,097 & $\$ 42,687,356$ & $\$ 61,463,881$ & $\$ 20,394,285$ & $\$ 103,282,024$ & $\$ 232,486,595$ \\
\hline
\end{tabular}


TABLE 49 (continued)

\begin{tabular}{|c|c|c|c|c|}
\hline Deposit Size in & & Deposits & & \\
\hline $\begin{array}{c}\text { Millions of } \\
\text { Dollars }\end{array}$ & $\begin{array}{l}\text { Business and } \\
\text { Persenel }\end{array}$ & Government & Interbank & $\begin{array}{l}\text { Accounts } \\
\text { Ala }\end{array}$ \\
\hline Less than 1 & 869,063 & 126,014 & 2,461 & 150,112 \\
\hline 1 to 2 & $3,455,233$ & 411,892 & 11,533 & 456,031 \\
\hline 2 to 5 & $12,475,704$ & $1,578,697$ & 61,949 & $1,425,179$ \\
\hline 5 to 10 & $14,134,372$ & $1,739,850$ & 98,158 & $1,447,516$ \\
\hline 10 to 25 & $19,609,380$ & $2,146,872$ & 326,646 & $1,839,140$ \\
\hline 25 to 50 & $13,927,627$ & $1,399,036$ & 404,145 & $1,238,140$ \\
\hline 50 to 100 & $13,226,131$ & $1,546,910$ & 838,857 & $1,312,629$ \\
\hline 100 to 250 & $18,976,259$ & $2,180,777$ & $2,198,951$ & $1,962,617$ \\
\hline 250 to 500 & $17,259,446$ & $1,840,138$ & $2,139,566$ & $1,867,037$ \\
\hline 500 to 1,000 & $15,752,637$ & $1,251,595$ & $2,051,566$ & $1,669,006$ \\
\hline 1,000 or more & $44,398,957$ & $3,009,246$ & $7,226,102$ & $5,425,834$ \\
\hline Total United States & $\$ 174,084,808$ & $\$ 17,231,027$ & $15,359,934$ & $\$ 18,793,241$ \\
\hline
\end{tabular}
1959.

Source: Anmal Report of the Federal Deposit Insurance Corporation, December 31 , 


\section{TABLE 50}

PERCEMTAGE COMPOSITION OF ASSETS AND LIABILITIES OF ALI INSURED COTMERCIAL BANKS IN THE UNITED STATES GROUPED BY DEPOSIT SIZE, JUNE 10, 1959

\begin{tabular}{lccccrr}
$\begin{array}{c}\text { Deposit Size In } \\
\text { Millions of } \\
\text { Dollars }\end{array}$ & $\begin{array}{c}\text { Mumber of } \\
\text { Banks }\end{array}$ & $\begin{array}{c}\text { Cash and Due } \\
\text { from Banks }\end{array}$ & $\begin{array}{c}\text { U.S. Govt. } \\
\text { Obligations }\end{array}$ & $\begin{array}{c}\text { Other } \\
\text { Securities }\end{array}$ & $\begin{array}{c}\text { Loans, } \\
\text { Di scounts } \\
\text { and Drafts }\end{array}$ & $\begin{array}{r}\text { Total } \\
\text { Assets }\end{array}$ \\
\hline Less than 1 & 10.67 & .48 & .65 & .34 & .44 & .50 \\
1 to 2 & 20.28 & 1.70 & 2.47 & 1.84 & 1.68 & 1.88 \\
2 to 5 & 33.17 & 6.01 & 8.40 & 7.89 & 5.91 & 6.72 \\
5 to 10 & 17.46 & 6.57 & 9.03 & 9.75 & 6.76 & 7.55 \\
10 to 25 & 11.19 & 9.17 & 12.29 & 13.48 & 9.47 & 10.46 \\
25 to 50 & 3.52 & 6.45 & 8.64 & 8.47 & 6.91 & 7.42 \\
50 to 100 & 1.71 & 6.97 & 8.08 & 8.53 & 7.10 & 7.46 \\
100 to 250 & 1.15 & 11.85 & 11.02 & 10.45 & 11.24 & 11.21 \\
250 to 500 & .45 & 11.68 & 9.17 & 8.84 & 10.66 & 10.28 \\
500 to 1,000 & .21 & 10.23 & 8.03 & 8.28 & 9.64 & 9.20 \\
1,000 or more & .14 & 28.84 & 22.19 & 23.04 & 30.15 & 27.33
\end{tabular}


TABLE 50 (continued)

\begin{tabular}{lcccc}
$\begin{array}{c}\text { Deposit Size in } \\
\text { Milions of } \\
\text { Dollars }\end{array}$ & $\begin{array}{c}\text { Business and } \\
\text { Personal }\end{array}$ & $\begin{array}{c}\text { Deposits } \\
\text { Government }\end{array}$ & $\begin{array}{c}\text { Interbank } \\
\text { Accounts }\end{array}$ \\
\hline Less than 1 & .50 & .73 & .01 & .80 \\
1 to 2 & 1.98 & 2.39 & .08 & 2.42 \\
2 to 5 & 7.17 & 9.16 & .40 & 7.58 \\
5 to 10 & 8.12 & 10.09 & .70 & 7.70 \\
10 to 25 & 11.44 & 12.46 & 2.13 & 9.78 \\
25 to 50 & 8.00 & 8.12 & 2.63 & 6.59 \\
50 to 100 & 7.60 & 8.98 & 5.46 & 6.98 \\
100 to 250 & 10.90 & 12.67 & 14.32 & 10.44 \\
250 to 500 & 9.91 & 10.67 & 13.93 & 9.93 \\
500 to 1,000 & 9.05 & 7.26 & 13.36 & 8.88 \\
1,000 or more & 25.50 & 17.46 & 47.04 & 28.87 \\
\hline
\end{tabular}

Source: Table XXIX. 
TABLE 51

ASSETS AND LIABILITIES OF ALL INSJRED CONRERCIAL BANKS IN OHIO GROUPED BY DEPOSIT SIZE JNE 10, 1959

(Amounts in Thousands of Dollars)

\begin{tabular}{|c|c|c|c|c|c|c|c|c|c|}
\hline $\begin{array}{l}\text { Deposit Size in } \\
\text { Milliens of } \\
\text { Dollars }\end{array}$ & $\begin{array}{l}\text { Murber of } \\
\text { Banks }\end{array}$ & $\begin{array}{l}\text { Cash and } \\
\text { Due from } \\
\text { Banks }\end{array}$ & & $\begin{array}{l}\text { S. Govt. } \\
\text { igations }\end{array}$ & $\begin{array}{l}\text { other } \\
\text { Securitles }\end{array}$ & $\begin{array}{l}\text { Loan: } \\
\text { ar }\end{array}$ & $\begin{array}{l}\text { Discounts } \\
\text { Drafts }\end{array}$ & & Total \\
\hline Less than 1 & 41 & 5,922 & 5 & 11,608 & 2,855 & 1 & 15,095 & $\$$ & 35,878 \\
\hline 1 to 2 & 94 & 23,908 & & 53,893 & 14,811 & & 68,214 & & 162,556 \\
\hline 2 to 5 & 197 & 109,925 & & 226,027 & 64,844 & & 298,577 & & 708,477 \\
\hline 5 to 10 & 123 & 138,697 & & 289,717 & 94,227 & & 433,479 & & 972,806 \\
\hline 10 to 25 & 91 & 213,997 & & 441,183 & 154,750 & & 657,642 & & $1,493,456$ \\
\hline 25 to 50 & 23 & 124,496 & & 275,676 & 76,184 & & 349,234 & & 840,936 \\
\hline 50 to 100 & 12 & 158,901 & & 351,010 & $96, \mathrm{LOL}$ & & 395,819 & & $1,020,748$ \\
\hline 100 to 250 & 7 & 269,650 & & 465,528 & 73,212 & & 538,669 & & $1,378,189$ \\
\hline 250 to 500 & 6 & 425,991 & & 657,815 & 153,427 & & 966,270 & & $2,234,333$ \\
\hline 500 to 1,000 & 2 & 272,282 & & 308,390 & 116,216 & & 602,727 & & $1,314,717$ \\
\hline 1,000 or more & 1 & 224,473 & & 272,168 & 107,411 & & 836,337 & & $1,451,187$ \\
\hline Total Ohlo & 597 & \$ 1,968, 242 & $\$$ & 353,015 & \$ 954,341 & $\$ 5$ & $, 162,063$ & & $1,613,283$ \\
\hline
\end{tabular}


TABLE 51 (continued)

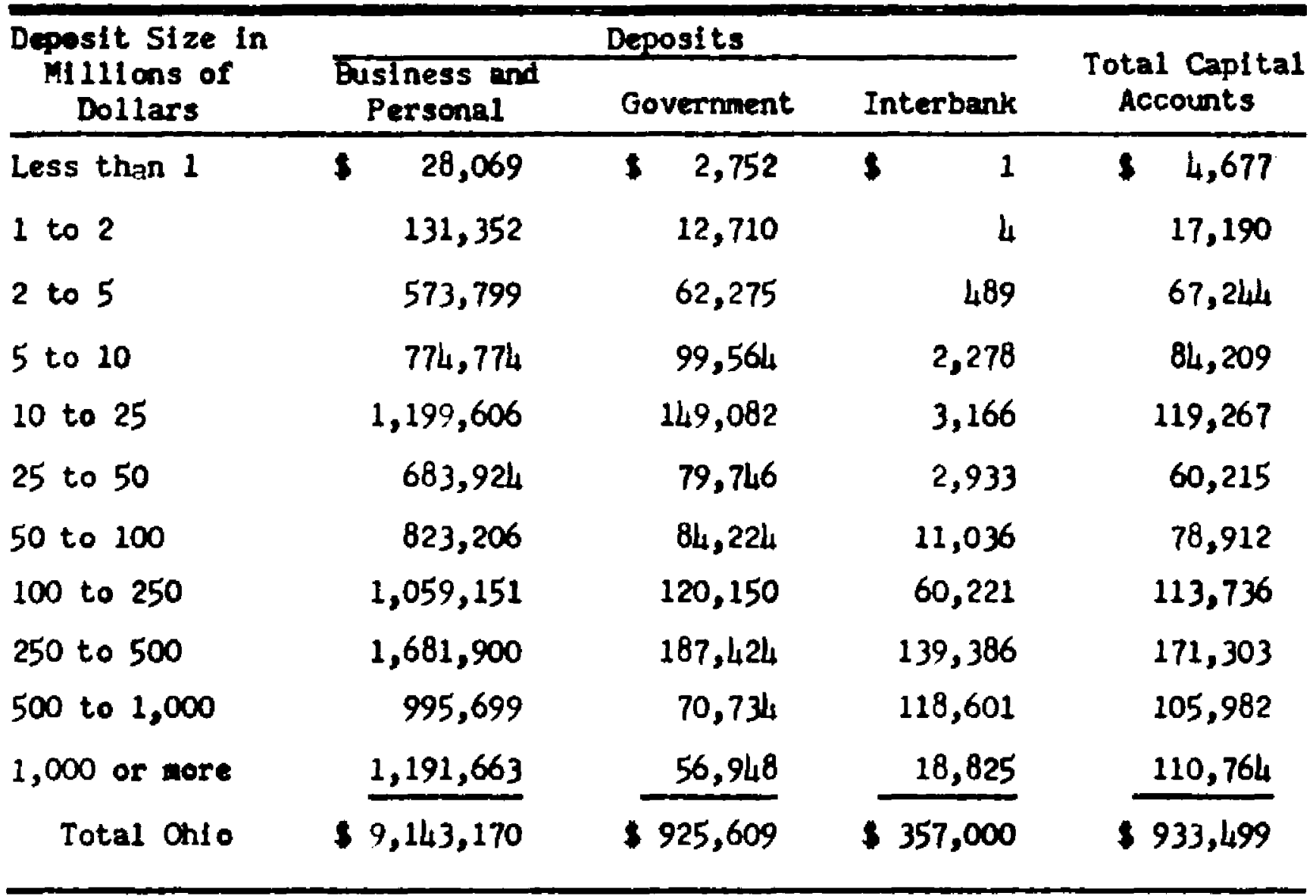

Source: Annual Report of the Federal Deposit Insurance Corporation, Decenber 31, 1959. 
TABLE 52

PERCEMTAGE COMPOSITION OF ASSETS AND LIABILITIES OF ALL IUSURED CONAERCIAL BANKS IN OHIO GROUPED

BY DEPCSIT SIZE, JUNE 10, 1959

\begin{tabular}{|c|c|c|c|c|c|c|}
\hline $\begin{array}{l}\text { Deposit Size in } \\
\text { Millions of } \\
\text { Dollars }\end{array}$ & $\begin{array}{l}\text { Number of } \\
\text { Banks }\end{array}$ & $\begin{array}{l}\text { Cash and Due } \\
\text { from Banks }\end{array}$ & $\begin{array}{l}\text { U. S. Govt. } \\
\text { Obiligations }\end{array}$ & $\begin{array}{c}\text { Other } \\
\text { Securities }\end{array}$ & $\begin{array}{l}\text { Loans, } \\
\text { Discounts, } \\
\text { and Drafts }\end{array}$ & $\begin{array}{l}\text { Total } \\
\text { Assets }\end{array}$ \\
\hline Less than $\$ 1$ & 6.86 & .30 & .35 & .30 & .29 & .30 \\
\hline 1 to 2 & 15.74 & 1.21 & 1.60 & 1.55 & 1.32 & 1.40 \\
\hline 2 to 5 & 33.00 & 5.58 & 6.74 & 6.79 & 5.78 & 6.10 \\
\hline 5 to 10 & 20.60 & 7.04 & 8.64 & 9.87 & 8.39 & 8.37 \\
\hline 10 to 25 & 15.24 & 10.87 & 13.15 & 16.21 & 12.73 & 12.86 \\
\hline 25 to 50 & 3.85 & 6.32 & 8.22 & 7.98 & 6.76 & 7.24 \\
\hline 50 to 100 & 2.01 & 8.07 & 10.47 & 10.10 & 7.66 & 8.79 \\
\hline 100 to 250 & 1.17 & 13.70 & 13.88 & 7.67 & 10.44 & 11.86 \\
\hline 250 to 500 & 1.01 & 21.64 & 19.61 & 16.08 & 18.71 & 19.23 \\
\hline 500 to 1,000 & .33 & 13.83 & 9.20 & 12.17 & 11.67 & 11.32 \\
\hline 1,000 or more & .16 & 11.40 & 8.12 & 11.25 & 16.20 & 12.50 \\
\hline
\end{tabular}


TABLE 52 (continued)

\begin{tabular}{lcccc}
\hline $\begin{array}{c}\text { Deposit Size in } \\
\text { Milions of } \\
\text { Dollars }\end{array}$ & $\begin{array}{c}\text { Business and } \\
\text { Personal }\end{array}$ & $\begin{array}{c}\text { Deposits } \\
\text { Government }\end{array}$ & $\begin{array}{c}\text { Interbenk } \\
\text { Total Copital } \\
\text { Accounts }\end{array}$ \\
\hline Less than $\$ 1$ & .31 & .30 & - & .50 \\
1 to 2 & 1.43 & 1.37 & - & 1.84 \\
2 to 5 & 6.27 & 6.72 & .01 & 7.20 \\
5 to 10 & 8.47 & 10.75 & .63 & 9.02 \\
10 to 25 & 13.12 & 16.10 & .88 & 12.77 \\
25 to 50 & 7.48 & 8.61 & .82 & 6.45 \\
50 to 100 & 9.00 & 9.09 & 3.09 & 8.45 \\
100 to 250 & 11.58 & 12.98 & 16.86 & 12.18 \\
250 to 500 & 18.39 & 20.24 & 39.04 & 18.35 \\
500 to 1,000 & 10.89 & 7.64 & 33.22 & 11.35 \\
1,000 or more & 13.03 & 6.15 & 5.27 & 11.86 \\
\hline
\end{tabular}

Source: Table 31. 
TABLE 53

DISTRIBUTION OF BRAMCH BANKS IN OHIO IN RELATION TO THE LOCATION OF THE PAREAT BANK

1945-1959

\begin{tabular}{llccc}
\hline Year & $\begin{array}{c}\text { Wumber of } \\
\text { Branches Located } \\
\text { in the Same CIty } \\
\text { as the Parent Bank }\end{array}$ & $\begin{array}{c}\text { Wunber of } \\
\text { Branches Located } \\
\text { in the Sane County } \\
\text { as the Parent Bank }\end{array}$ & $\begin{array}{c}\text { Nuber of Branches Located } \\
\text { in a County Cont ingent to } \\
\text { the County in Which the } \\
\text { Parent Bank Is Located }\end{array}$ & $\begin{array}{c}\text { Nuber of Branch Bank } \\
\text { Located at Uni ted } \\
\text { States Government } \\
\text { Establi shments }\end{array}$ \\
\hline 1945 & 118 & 48 & 5 & 4 \\
1946 & 120 & 48 & 5 & 4 \\
1947 & 128 & 53 & 5 & 3 \\
1948 & 140 & 56 & 5 & 3 \\
1949 & 145 & 61 & 6 & 3 \\
1950 & 149 & 70 & 5 & 2 \\
1951 & 159 & 80 & 5 & 3 \\
1952 & 175 & 88 & 5 & 3 \\
1953 & 190 & 110 & 5 & 3 \\
1954 & 207 & 128 & 5 & 3 \\
1955 & 226 & 146 & 5 &
\end{tabular}


TABLE 53 (continued)

\begin{tabular}{ccccc}
\hline $\begin{array}{c}\text { Nuber of } \\
\text { Year }\end{array}$ & $\begin{array}{c}\text { Mranches Located } \\
\text { in the Same City } \\
\text { as the Parent Bank }\end{array}$ & $\begin{array}{c}\text { Branches Located } \\
\text { in the Sane County } \\
\text { as the Parent Bank }\end{array}$ & $\begin{array}{c}\text { Nuber of Branches Located } \\
\text { in a County Contingent to } \\
\text { the County in Which the } \\
\text { Parent Bank Is Located }\end{array}$ & $\begin{array}{c}\text { Number of Branch Bahk } \\
\text { Located at United } \\
\text { States Governaent } \\
\text { Establl shments }\end{array}$ \\
\hline 1956 & 259 & 178 & 6 & 3 \\
1957 & 262 & 212 & 6 & 3 \\
1958 & 307 & 246 & 9 & 3 \\
1959 & 315 & 273 & 10 & 3 \\
\hline
\end{tabular}

Source: Federal Reserve Bullet in, April and May issues, 1946-1960. 
TABLE 54

TOTAL RESQURCES AND BRANCH OFFICES OF ALI BANKS AFFILIATED WITH THE BANCOHIO CORPORATION ON DECEMBER 31, 1945

\begin{tabular}{|c|c|c|}
\hline Name of Bank & $\begin{array}{c}\text { Total } \\
\text { Resources }\end{array}$ & $\begin{array}{c}\text { Number of } \\
\text { Branch } \\
\text { Offices }\end{array}$ \\
\hline $\begin{array}{l}\text { The Onio Mational Bank, Colunbus } \\
\text { The First Mational Bank, Springfield } \\
\text { The First Mational Bank, Coshocton } \\
\text { The Citizens Mational Bank, Zanesville } \\
\text { The First Mational Bank, Chillicothe }\end{array}$ & $\begin{array}{r}207,015,000 \\
24,481,000 \\
12,471,000 \\
11,725,000 \\
11,346,000\end{array}$ & 12 \\
\hline $\begin{array}{l}\text { Uni nn-Lick Ing Bank, Newark } \\
\text { The First Wat fonal Bank, Delaware } \\
\text { Fifth Avenue Savings Bank, Colunbus } \\
\text { Nat onal Bank of Portshouth } \\
\text { The Hocking Valley Mati onal Bank, Lancaster }\end{array}$ & $\begin{array}{l}8,570,000 \\
8,394,000 \\
7,975,000 \\
7,614,000 \\
6,427,000\end{array}$ & \\
\hline $\begin{array}{l}\text { The First National Bank, Washington C.H. } \\
\text { The First Mati cnal Bank, Tiffin } \\
\text { The First Natl onal Bank, Cadiz } \\
\text { The First National Bank, London } \\
\text { The Farners and Merchants Bank, Logan }\end{array}$ & $\begin{array}{l}5,099,000 \\
5,014,000 \\
4,844,000 \\
4,836,000 \\
4,116,000\end{array}$ & \\
\hline $\begin{array}{l}\text { The First Mational Bank, Marysville } \\
\text { The Second Mational Bank, Circleville } \\
\text { The State Industrial Bank, Columbus } \\
\text { Perry County Bank, New Lexington }\end{array}$ & $\begin{array}{l}4,043,000 \\
2,429,000 \\
1,816,000 \\
1,554,000\end{array}$ & \\
\hline Total & $\$ 339,669,000$ & 12 \\
\hline
\end{tabular}

Source: Moody's Manua1 of Investments, 1946. 


\section{TABLE 55}

TOTAL RESOURCES AND BRAYCH OFFICES OF ALl BANKS AFFILIATED WITH THE BANCOHIO CORPORATION ON DECEMBER 31, 1959

\begin{tabular}{|c|c|c|}
\hline Name of Bank & $\begin{array}{c}\text { Total } \\
\text { Resources }\end{array}$ & $\begin{array}{l}\text { Huber of } \\
\text { Branch } \\
\text { Offlces }\end{array}$ \\
\hline $\begin{array}{l}\text { The Ohio National Bank, Columbus } \\
\text { The First Hational Bank, Springfield } \\
\text { The First National Bank, Hewark } \\
\text { Citizens Mational Bank, Zenesville } \\
\text { The First National Bank, Chil11 cothe }\end{array}$ & $\begin{array}{r}450,203,000 \\
36,145,000 \\
24,435,000 \\
20,552,000 \\
18,843,000\end{array}$ & $\begin{array}{r}18 \\
2 \\
1 \\
2\end{array}$ \\
\hline $\begin{array}{l}\text { The Flrst National Bank, Coshocton } \\
\text { The Onfo State Bank, Columbus } \\
\text { The First Hational Bank, Deleware } \\
\text { Hocking Valley Uational Bank, Lancaster } \\
\text { Worthington Savings Bank, Worthington }\end{array}$ & $\begin{array}{l}16,485,000 \\
16,183,000 \\
14,019,000 \\
13,324,000 \\
13,323,000\end{array}$ & $\begin{array}{l}2 \\
2\end{array}$ \\
\hline $\begin{array}{l}\text { The Hational Bank of Port smouth } \\
\text { The First Wat ional Bank, Wilinlington } \\
\text { Farmers and Merchants Bank, Logan } \\
\text { Knox County Savings Bank, Mt. Vernon } \\
\text { The Flrst Wattonal Bank, Washington C.H. }\end{array}$ & $\begin{array}{r}12,956,000 \\
12,150,000 \\
11,008,000 \\
9,638,000 \\
8,587,000\end{array}$ & 1 \\
\hline $\begin{array}{l}\text { The First Hational Bank, Cadiz } \\
\text { The First Hational Bank, Tiffin } \\
\text { The First Mational Bank, Marysvilie } \\
\text { The First National Bank, London } \\
\text { Kenton Savings Bank, Kenton }\end{array}$ & $\begin{array}{l}8,562,000 \\
8,366,000 \\
7,947,000 \\
7,231,000 \\
5,42,000\end{array}$ & 2 \\
\hline $\begin{array}{l}\text { The Second National Bank, Circleville } \\
\text { Perry County Bank, New Lexington }\end{array}$ & $\begin{array}{l}4,426,000 \\
3,522,000\end{array}$ & \\
\hline Total & $\$ 723,329,000$ & 29 \\
\hline
\end{tabular}

Source: Moody's Monual of Investments, 1960. 
BIBLIOGRAPHY

304 


\section{BIBLIOGRAPHY}

\section{A. BOOKS}

Alhadeff, David A. Monopoly and Competition In Banking. Berkeley, California: University of Callfornia Press, 1954.

Bach, George L. Federal Reserve Pollicy-Making. New York: Alfred A. Knopf, 1950 .

Beckhart, Benjamin H. (editor). Business Loans of American Counercial Banks. New York: The Ronald Press Company, 1959.

Chapman, John M. Concentration of Banking. New York: Columbla Universi ty Press, 1934.

Chapnan, John M, and Westerfield, Ray B. Branch Banking. New York: Harper and Brothers, 1942.

Cartinhour, Gaines T. Branch, Group and Chain Banking. New York: The Macnillan Company, 1931.

Donaldson, Elvin F. Corporate Finance. New York: The Ronald Press Compeny, 1957.

Finney, Katherine. Interbank Deposits. New York: Columbia University Press, 1958.

Hogenson, Palmer T. Econonics of Group Banking. Washington, D.C.: Public Affairs Press, 1956.

Livingston, Homer J. Management Policies in American Banks. Hew York: Harper and Brothers, 1956.

Robinson, Roland I. (editor). Financial Institutions. Homewood, Illinols: Richard D. Irwin, Inc., 1959.

- The Managenent of Bank Funds. New York: MoGraw-Hill Book Company, Inc., 1951.

Stelner, W. H., Shaplro, Eli, and Solcmon, Ezra. Money and Banking. New York: Henry Holt and Company, 1958.

Vernon, Raymond. The Changing Economic Function of the Central City. New York: Comittee on Economic Development, 1958 . 
Whitsett, James M. Banking Operations in Ohio, 1920-1940. Colubus, ohio: The Ohlo State University Bureau of Business Research, 1941.

Wiesenberger, Artmur, Investment Companies. New York: Arthur Hiesenberger and Company, 1960.

\section{B. REPORTS}

Bogen, Jules I. The Adequacy of Bank Earnings. New York: New York University Graduate School of Business Administration, 1959.

- The Competitive Position of Comerclal Banks. New York: New York University Graduate School of Business Adnini stration, 1958.

Flexner, Kurt $F$. The Role of Savings and loan Associations in the Banking Communi ty of the State of New York. New York: The Savings Association League of New York State, 1959.

Freeman, Gaylord A. Mutual Competition. Chicago, Illinols: The First Wational Bank of Chicago, 1959.

Horvitz, Paul M. Concentration and Competition in New England Bank1ng. Boston: Federal Reserve Bank of Boston, 1958.

Lent, George E. The Changing Structure of Comercial Banking. Hanover, New Hampshire: The Amos Tuck School of Business Admin1 stration, 1960.

McFadden, Business Publications. American Bank Directory, 1960. Atlanta, Georgia: McFadden Business Publlcations, 1960.

Moody's Investors Service. Moody's Mamual of Investments. New York: Moody's Investors Service, 1946 to 1960.

Nadler, Marcus, and Bogen, Jules I. The Bank Holding Company. New York: New York Uni versity Graduate School of Business Admini stration, 1959.

National Association of Investment Companies. Investment Companies. A Stati stical Sumary, 1940-1959. New York: Natianal Issociation of Investment Companies, 1960.

New York State Banking Department. Postwer Banking Developments in Wew York State. Albany, New York: New York State Banking Department, 1959. 
M. A. Schaplro and Conpany, The Triple Banking System. New York:

M. A. Schapiro and Company, 1956.

Ohio Bankers Association. How Does Your Bank Measure Up?. Colunbus, Chio: Ohio Bankers Association, 1946-1960.

R. L. Polk and Company. Polk's Bankers Encyclopedia. Detrolt, Michigan: R. L. Polk and Company, 1946 and 1960.

United States Savings and Loan League. Savings and Loan Fact Book, 1960. Chl cago, Illinois: United States Savings and Loan League, 1960.

C. PUBLIC DOCUMENTS

Annual Report of the Comptroller of the Currency. 1945 to 1959.

Annual Report of the Federal Deposit Insurance Corporation. 1945 to 1959.

Annual Report of the Onlo Department of Insurance. 1950 to 1960.

Annual Report of the Ohio Division of Banks. 1946 to 1960.

Annual Report of the Ohio Division of Bullding and Loan Associations. 1946 to 1960 .

Annual Report of the Secretary of the Treasury on the State of Finances. 1946 to 1959.

Board of Governors of the Federal Reserve System. Distribution of Bank Deposits by Counties, December 31, 1947. Washingto n, D.C., July, 1948.

- Distribution of Bank Deposits by Counties and Standard Metropo1ltan Areas, June 15, 1960. Washing ton, D.C. Decenber, 1960.

- Payment of Interest on Deposits, Regulation Q. Washington, D.C. January 1, 1947 .

Federa1 Deposit Insurance Corporation. Changes in the Humber of Banking Offices, 1859-1958, and in Banking Concentration 1921-1958. Washingtion, D.C. January 1960 .

Federal Reserve Bank of Cleveland. Fourth District Banks. Cleveland, Onfo. Apr11 30, 1960. 
- Member Bank Operating Ratios Fourth Federal Reserve DIstrict, 1959. Cleveland, Oh10. 1959.

- Number of Banks in Fourth Federal Reserve District in Actual Operation on Deceuber 31, 1959. Cleveland, Ohio. 1960.

- Muber of Branches Operated by Member and Nonmenber Banks In Fourth District onDecember 31, 1959. Cleveland, Ohio. 1960.

Ohio Department of Comerce. Analysis and Recepitulation of Reports Filed by 983 offices Licensed Under the ohio small Loan Aft for the Year Ending Decenber 31, 1959. Colusbus, कh 0.1960.

1958.

- Banking Laws of Ohio Annotated, 1958. Columbus, Ohio.

Ohio Department of Industrial and Economic Development. Ohio PopulatIon Growth and Distribution. Columbus, Ohio. 1960.

- Statistical Abstract of Ohio: 1960. Columbus, Ohio. 1960.

Ohio General Code Annotated, 1926.

U. S. Bureau of the Census. Statistical Abstract of the United States. 1946 to 1959.

U. S. Congress, House Comittee on Banking and Currency. Regulation of Benk Mergers. Hearings before Subcomittee No. 2 on S. 1062. B6th Congress, and Session, February 16, 17, and 18, 1960. Washington, D.C.: United States Goverment Printing Office, 1960.

11. S. Congress, House Comittee on the Judiclary. Bank Mergers. Hearings before Antitrust Subcomittee (Subcomittee Mo. 5 ) on H. R. 5498. 84th Congress, 1st Session, July 5 and 6, 1955, Serial No. 7. Washington, D.C.: United States Goverment Printing Office, 1955.

- Bank Mergers and Concentration of Benking Facilities. Stalf Report subitted to the Antitrust Subconittee (Subcom altee No. 5), September 17, 1952. 82d. Congress, 2d. Session. Washlngton, D.C.: United States Goverment Printing Office, 1952.

- Current Antitrust Probleas. Hearings before Antitrust Subccaonit tee (Subcomittee No. 5), Blth Congress, 1st Session, May 10-18, 1955, Part I, Serial No. 3. Washington, D.C.: United States Goverment Printing Office, 1955. 
- Current Antitrust Problems. Hearings before Antitrust Subccait tee (Subcanittee No. 5). 84th Congress. 2 st Session, May 23, 24, 25, and June 6, 1955, Part II, Serial Wo. 3, Washington, D.C.: United States Government PrInting Offlce, 1955.

- Current Antitrust Problems. Hearings before Antitrust Subcomit tee (Subccintter Wo. 5). 8hth Congress, 1st Session, June 7-17, 1955, Part III, Serial No. 3. Washington, D.C.: United States Goverment Printing Office, 1955.

- Prenerger Notification. Hearings before Antitrust Subcomittee (Subcomittee Ho. 5). on H. R. 26L and H.R. 2143. 85th Congress, 1st Session, May 6, 7, 8, 20, and 21, 1957, Serlal No. 2. Washington, D.C.: United States Goverment Printing Office, 1957.

U. S. Congress, House Cormittee on Small Business. Benking Concencentration and Snall Business. Staff Report subnitted to the Select Comittee on Sinall Business, December 23, 1960. 86th Congress, 2d. Session. Washington, D.C.: United States Government Printing Office, 1960.

U. S. Congress, Senate Committee on Banking and Currency. Control of Bank Holding Companies. Hearings before a Subcomittee on S. 880, S. 2350, and H.R. 6227, July 5, 6, 7, 11, 12, and 14, 1955 . 84th Congress, 1st Session. Washington, D.C.: United States Government Printing Office, 1955.

- Regulation of Bank Mergers. Hearings before a Sub comittee on S. 3911 , June 12 and 18, 1956. 84th Congress, 2d. Sesslon. Washington, D.C.: United States Government Printing Office, 1959.

- Regulation of Bank Mergers. Hearings on S. 1062, March 18 and 19, 1959. 86th Congress, 1st Session. Washington, D.C.: United States Goverment Printing Office, 1959.

Federal Code Annotated. 1960.

\section{PERIODICALS}

Alhadeff, David A. "The Market Structure of Commerclal Banking in the United States," Quarterly Journal of Edonoaics, February, 1951, pp. 62-86. 
Alhadeff, Charolette P. and Alhadeff, David A. "Recent Bank Mergers," Quarterly Journal of Econonles, November, 1955, pp. 503-532.

Anderson, O. E. "Changing Times End Ohio's Last Private Bank," The Ohio Banker, August, 1956, pp. 12-13.

"Answer to Credit Unions; the Same Service on the Same Premises," Banking, July, 1959, p. 105.

"Bank Holding Companies Get a Learned Orchid," Business Week, February 7, 1959, p. 52 .

"Bank Holding Company Has Investment Appeal," Flnancial World, March 25, 1959, pp. 10-11.

Berle, A. A., Jr. "Banking Under the Antitrust Laws," Columbia Law Review, 49:589-606, May, 1949.

Bratter, Herbert. "How Goes the Battle for Tine Deposits?" Banking, August, 1960, pp. 41, $146 \mathrm{f}$. pp. $34-36$.

"TheTrend in Bank Mergers," Banking, Apri 1, 1959,

"Businessmen Size Up Their Banks," Dun's Review and Modern Industry, June, 1959 , P. 26.

Chandler, Lester V. Monopolistic Elements in Comerclal Banking," Journal of Political Economy, February, 1938, pp. 1-22.

Chapman, Richard P. "The Bahkers Di lemma," Harvard Business Review, July-August, 1953, pp. 51-59.

"City Banks Lure Country Dollars," Business Week, October 24, 1959, pp. $46-48$.

"Comercial Banks Competitive P1ight," Benking, August, 1959, p. 126.

Donoguhe, John. "The Spence-Roberts on Act," Burroughs Clearing House, June, 1956, pp. 37-39.

Ei senann, Dor's M. "Extent of Concentration in Banking," Banking, October, 1955, pp. 48, 144 .

Federal Reserve Bank of Boston. "The Bank Merger Movement," New England Business Revi ew, May, 1959, pp. 5-7.

- "The Growth of Branch Banking," New England Business Revier, Apri1, 1959, pp. 1-4. 
Federal Reserve Bank of Kansas City. "Growth and Earnings at Individual Comercial Banks," Monthly Review, July, 1960, pp. 3-9.

- Importance of Size and Other Factors Affecting Bank Costs," Monthly Review, Apri1, 1961, pp. 10-15.

- "Interpretation of Size-Cost Relationships in Banking," Monthly Review, March, 1961, pp. 3-9.

Review, February, 1961, pp. 3-9.

Federal Reserve Bank of Philadelphia. The Branch and Merger Movement in the Third Federal Reserve District," Business Review, August, 1954, pp. 2-6; September, 1954, pp. 3-12; Novenber, 1954, pp. 10-19; January, 1955, pp. 2-11; March, 1955, pp. 3-7.

"Federal-State Relations Under the Bank Holding Company Act of 1956," Yale Law Journal, 66-1093, June, 1957.

Funk, C. W. "Antitrust legislation Affecting Bank Mergers," Banking Law Journal, 12: 496 , May, 1958.

Gruis, E. G. "Antitrust Laws and Their Application to Banking," Banking Law Journal, 73:793, November, 1956.

Harfield, Henry. "Legal Restraints on Expanding Banking Facilities, Competition and the Public Interest, " The Business Lawyer

"Hobbled Banking-Polltics Must Not Interfere with Effective Competition," Barron's, Apri1 6, 1959, pp. 1 ff.

Whousing a New Branch Office; High Constructl on Costs Present Serious Problems," Banking, August, 1958, pp. 52-55.

Krelder, Lawrence E. "Bank Capital Problems in Rural Areas May Become Crucial," Banking, February, 1960, p. 82.

Lagomarcino, Paul D. "Impact of 12 Per cent Reserve Income Tax Provision Upon the Banking Structure, " Banking Law Journal, 75: 921, Novenber, 1958.

Lerner, Eugene M. and Jacobs, Donald P. Why We Need a Better Market for Bank Stock," Banking, August, 1960, pp. 43-45; September, 1960, $76 \mathrm{ff}$.

Moclatchy, D. F. "Commerclal Banks Need Not Be Crowded Out of the Market for Savings Accounts," The Business Lawyer, 15: 391, July, 1960. 
McDaniel, Robert. "Where's Ohio Banking Headed?" The Ohio Banker, June, 1958, pp. 27-28.

Paten, Thomas B. "Conversion, Merger and Consolidation Leglslation-Two-Way Street for National and State Banks," Banking Law Journal, $71: 15$, January, 2954.

Ransey, M. L. "Banks and the Antitrust Laws: An Unresolved Problem," Amerl can Bar Assoclation Journal, 37:427-30, June, 1951.

"Report of the Transamerica Case," Banking Law Journal, 71:22, Jamuary, 1954 .

Robertson, Willis A. "The Bank Holding Company Act," Banking, June, 1956, pp. 42, $157 \mathrm{ff}$.

"Slackening Bank Mergers," Burroughs Clearing House, June, 1958, p. 8.

Speagle, R. E. "Bank Stocks at the Di scount," Harvard Business Review, Jamuary-February, 1951, pp. 99-106.

Stewart, Will1am C. How Business Picks Barks," Burroughs Clearing House, January, 1960, pp. 33-35.

Tyng, Ed. "Bank Merging Today. - No Job for Boys," Burroughs Clearing House, January, 1960, pp. 47, 98.

- "Factors Behind the Trend of Bank Consolidations," Burroughs Clearing House, May, 1955, pp. 36, $97 \mathrm{ff}$.

Wasem, G. M. "Why Business Oustomers Choose a Bank," Banking, Apri1, 1959, p. 46.

Weart, Spencer A. "Developing Shopping Center Branches, "Burroughs Clearing House, June, 1958, pp. 32-33.

\section{E. NEWSPAPERS}

Adams, Alexander B. "Recouping Market Share is Banking's Great Challenge," The Comerclal and Financial Chronicle, November 7, 1957, pp. 12-13.

Adams, E. Sherman. measures to Sustain Banks Proflt Position, " The Comerclal and Flnancial Chronlcle, December 10, 1959, pp. 14-15. 
Cook, Ear1 H. "Adequacy of Bank Capital and the Sale of Bank Shares," The Commercial and Financial Chronicle, October, 17, 1957, p. 22.

Gidney, Ray B. "Conmercial Banks Victims of Inequitable Tax Burden," The Commercial and Financial Chrontle, November, 26, 1959, pp. 15, 25.

- "Growth of Mation's Banking Institutions," The Commerclal and FInancial Chronicle, October 1, 1959, p. 16.

Grainger, Isaac B. "Capital Requil rements of Banks," The Comercial and Financial Chronicle, Jamuary 31, 1957, p. 12.

Kinbre1, M. Monroe. "Bank Leglslation and Congress," The Comerclal and Financial Chronicle, October 1, 1959, p. 16.

Kraus, Albert I. "Antl trust Views of Kennedy Eyed," The New York Times, March 5, 1961, pp. 1, 9 F.

"Government Eyes Banking Mergers," The New York Times, Varch 5, 1961, pp. 1, 5 F.

- U. S. Suit to Bar Bank Merger Involves Many Points of Law," The New York Tines, June 4, 1961, pp. 1, 12 F.

Lawson, Herbert G. "Financial Institutions' Rivalry for Savlngs Grows, Promoti onal Spending Stepped Up," The Wall Street Journal,

December 28, 1960, p. 22.

McCloy, John J. "Bank Mergers," The Commercial and Financial Chronicle, July 7, 1955, pp. 1, 33-34.

Nadler, Marcus. "Comercial Banks Face Impact of Transitional Economic Changes," The Comercial and Financlal Chronicle, June 6, 1957, pp. 12-13.

Quantius, Frances H. "Bank Mergers: Important Factor in Econonic Growth," The Comercial and Financlal Chronlcle, August 20, 1959, pp. 1,20 .

Ryan, John. "Branch Banking and Banking Facillties," The Commercial and Financial Chronicle, Jenuary 12, 1956, pp. 1, 28-30.

- "Inablilty of Bank Merger Law to Deal with Local

Mergers," The Comercial and Financial Chronicle, October 18, 1956, pp. 18-19.

Silberman, Lee. MExpanding Banks: Many Step Up Opening of Branches as Legal Hurdles Slow Mergers," The Wall Street Journal, June 5, 1961 , pp. 1,6 . 
Warner, Bradford A. "Banks Must Face Competition by Marketing Bank Services," The Comercial and Financlal Chronicle, November 20, 1958, pp. 13,25 .

Weston, Fred J. "Signt ficance of Bank Mergers," The Comerclal and Financlal Chronicle, Jamiary 10, 1957, pp. 10-11.

Millians, Mardo. "Banking Institutions Expand Services," Columbus Evening Diupatch, November 20, 1960, p. 34 . DIspatch, Noveaber 14, 1960, p. 22.

- MOhi oans Thriftest, Says S-L official, "Columbus Evening

Willis, Brooke. "Sone Present Banking Problems," The Conmercial and Financial Chronicle, July 3, 1958, pp. 5, 26.

Wolcott, Jesse P. "Twenty-five Years--Past and Future, "The Comnercial and Financial Chronicle, October 2, 1958, pp. 20, 30 .

\section{F. UNPUBLISHED MATERIAL.}

Letter from John W. Hughes, Research Department, Carlisle and Jacquelin, New York 4, N.Y., March 2, 1961.

Letter fron Harold $S$. Oberg, Research Di rector, Mational Association of Investment Companies, Nes York 5, N.Y., March 16, 1961.

Letter from Vito Natrelia, Assi stant Di rector, Division of Trading and Exchanges, Securities and Exchange Conerission, Washington 25, D.C., March 16, 1961.

Ohio Credit Uni on League. Number and Total Assets of Credit Unions in Operation in Ohio. 1945-1959. (Typewritten)

\section{G. OTHER SOURCES}

Bancohlo Corporation. Personal Interview with Mr. Henry Honrath, Comptroller. March 13, 1961.

Federal Deposit Insurance Corporation. Personal Interview with Mr. Gilbert E. Mounts, Supervising Exeminer, District Four. February 3, 1961.

Federal Reserve Bank of Cleveland. Personal Interview with Mr. Paul Stetzelberger, Vice President in charge of the Exanination Department. Jenuary 31,1961 . 
Ohio Benkers Association. Personal Interview with Mr. Belford P. Atkinson, Executive Manager. February 28, 1961.

Ohio Division of Banks. Personal Intervied with Mr. R. H. Willet, Superintendent of Banks. March 24, 1961.

Ohio Division of Securities. Personal Interview with Mr. Joseph A. W1 lmes, Supervisor. March 7, 1961.

Springfield Savings Soclety. Interview with Mr. Donald Wiegel, President. March 21, 1961. 


\section{AUTOBIOGRAPHY}

I, John Thomas Hackett, was born In Fort Wayne, Indiana, October 10, 1932. I recelved secondary-school education in the public schools of North Manchester, Indtana, and ay undergraduate training at Indiana University, which granted me the Bachelor of Science degree in 1954. Fron Indiana University, I recelved the Master of Business Administration degree in 1958. In October, 1958, I becane an Assistant in the Department of Business Organlzation at The OhIo State University, and later Instructor. I held these positions for three years while completing the requirements for the Doctor of Philosophy degree. In September, 1961, I became an Associate Econonl st in the Research Department of the Federal Reserve Bank of Cleveland. 